SEEING LIKE A CITIZEN: ACCESS TO WATER IN URBAN AND RURAL TANZANIA 
Graduation committee:

\section{Chairman/secretary}

Prof.dr.ir. A. Veldkamp

\section{Supervisor}

Prof.dr. P.Y. Georgiadou

\section{Co-supervisor}

Dr. J.A. Martinez Martin

\section{Members}

Prof.dr. M.J. Kraak

Prof.dr.ir. M.F.A.M. van Maarseveen

Prof.dr. S. Sahay

Prof.dr. W.T. de Vries

Dr. L.E.M. Taylor
University of Twente

University of Twente

University of Twente University of Twente University of Oslo, Norway TU München, Germany Tilburg University

ITC dissertation number 303

ITC, P.O. Box 217, 7500 AE Enschede, The Netherlands

ISBN: $978-90-365-4366-8$

DOI: $10.3990 / 1.9789036543668$

URL: https://dx.doi.org/10.3990/1.9789036543668

Cover designed by Benno Masselink

Printed by ITC Printing Department

Copyright (c) 2017 by K.O. Nganyanyuka

TU FACULTY OF GEO-INFORMATION SCIENCE AND EARTH OBSERVATION 


\title{
SEEING LIKE A CITIZEN: ACCESS TO WATER IN URBAN AND RURAL TANZANIA
}

\author{
DISSERTATION
}

to obtain

the degree of doctor at the University of Twente, on the authority of the rector magnificus, prof.dr. T.T.M. Palstra, on account of the decision of the graduation committee, to be publicly defended on $12^{\text {th }}$ day of July 2017 at 14.45 hrs

by

Kapongola Oswald Nganyanyuka

born on $11^{\text {th }}$ March 1978

in Kilwa, Tanzania 
This thesis has been approved by

Prof. dr. Yola Georgiadou, supervisor

Dr. Javier Martinez, co-supervisor

Dr. Juma Hemed Lungo, co-supervisor 


\section{Acknowledgements}

My five years of PhD studies at the University of Twente would not have been possible without the personal, professional and financial support of countless people and organisations.

I would like to acknowledge the Netherlands Organization for Scientific Research-Science for Global Development (NWO-WOTRO) for funding my PhD studies.

I am very grateful to my promoter Prof. Yola Georgiadou for her scholarly guidance. She is a great person and a prominent scholar. This study would not have been possible without her unparalleled encouragement, support and advice which were very useful in bringing this study to intellectual fruition. Indeed I benefited enormously from her intellectual input. I would also like to extend my gratitude to my supervisors, Dr. Juma Lungo and Dr. Javier Martinez for helping me shape my ideas throughout the study period. I would also like to thank Dr. Anna Wesselink not only for reading initial drafts of my thesis chapters and provide constructive comments but also for her generosity to share cake recipes and organizing visits to Dutch museums.

I have been fortunate to undertake this research under a research project titled 'Sensors Empowerment and Accountability (SEMA)' and thus have enjoyed the company of its members throughout the journey. In that regard, I would like to acknowledge the support, unsurpassed knowledge and experience offered by Prof. Robert Hoppe, Mr. Jeroen Verplanke, Dr. Rob Lemmens, Prof. MennoJan Kraak, Dr. Benson Bana, Dr. Mercy Mbise and Mr. Charles Bundu. I also thank my fellow PhD students in the SEMA research project, Dr. Jesper Katomero and Mr. Habtom Tsega.

I am also indebted to the management of Gatsby Africa and Cotton Sector Development Programme (CSDP) particularly Duncan Rhind (Programme Director), Jeremy Muthoni (Performance Measurement Manager), Louis Kivuyo (Human Resource Manager) for recruiting me prior to my graduation and the support they accorded during the last few months of my studies. In addition, I am very grateful to David Boselie, Gatsby Africa's Deputy Director, Monitoring, Evaluation \& Learning, for the support and volunteering to attend my defence.

My special thanks goes to my wife, Anansia Uroki for her continued love, support and encouragement during the course of the study. I also thank my wonderful daughters Claire and Ellen for quietly enduring hardships particularly during my absence - I first set my eyes on Ellen when she was 4 months. I extend my profound thanks and appreciation to my mother, Ms. Rehema Omary Millanzi for her love, support and motivation throughout my life. This 
study kept me out of Tanzania when she was retiring and she endured its challenges singlehandedly. I would also like to extend my thanks to my late grandfather Mr. Cassian Kawacha for his enduring support and encouragement. It is unfortunate that he passed away when this journey was almost over. I dedicate this thesis to him.

It is impossible to mention each and every one of those who have contributed to my academic journey and particularly this study; in that regard, I am forever grateful to all who have been part of this endeavour.

While I acknowledge the invaluable contributions of various people and organisations to this study, including those not mentioned here, I take full responsibility for any shortcomings of the thesis. 


\section{Table of Contents}

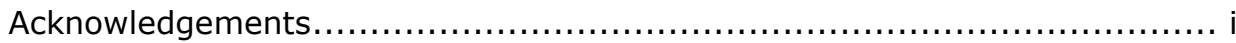

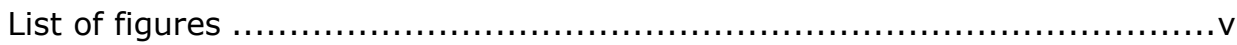

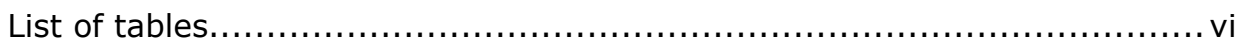

Chapter 1 Introduction..........................................................

$1.1 \quad$ Water access in Sub-Saharan Africa.....................................

1.2 My personal narrative of access to water in Tanzania ................10

1.3 The potential of ICT and mobile phone-based platforms............17

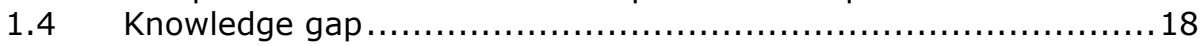

$1.5 \quad$ Research questions ................................................ 19

1.6 Framing the thesis within the SEMA research project................19

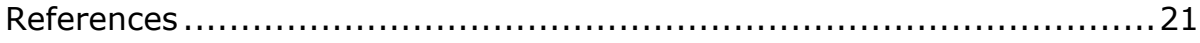

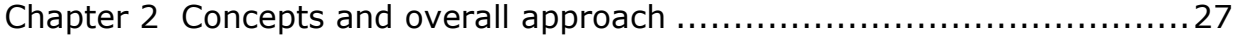

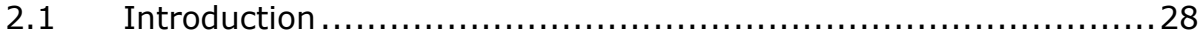

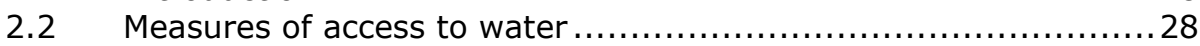

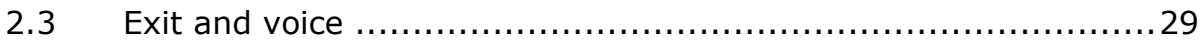

2.4 Formal and informal organizational structures ........................ 30

2.5 Discretion and transaction-intensiveness .............................. 32

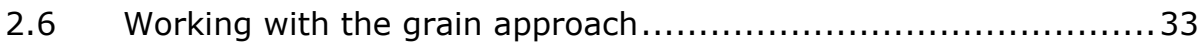

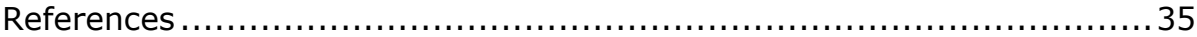

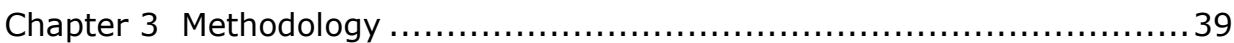

3.1 Research approach................................................ 40

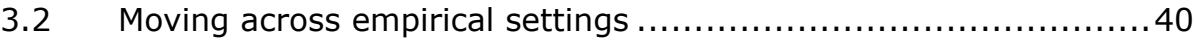

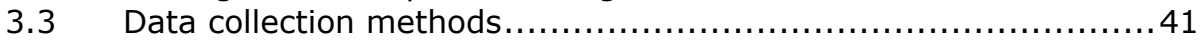

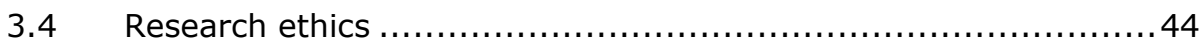

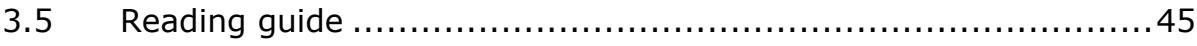

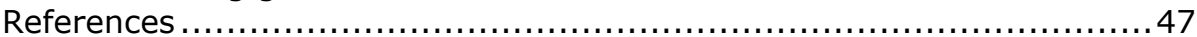

Chapter 4 Accessing water services in Dar es Salaam: are we counting what

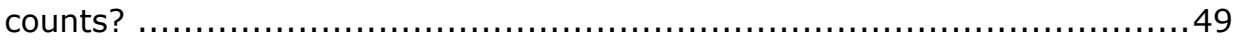

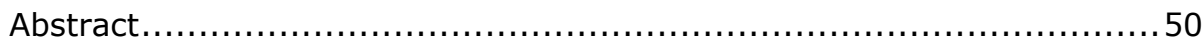

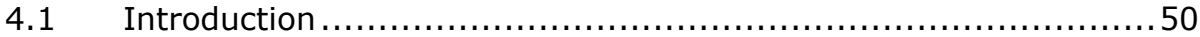

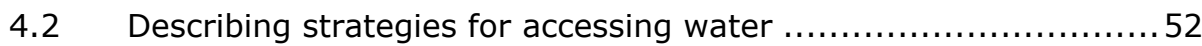

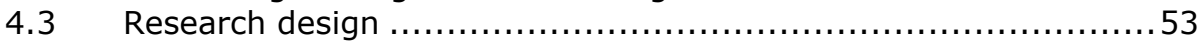

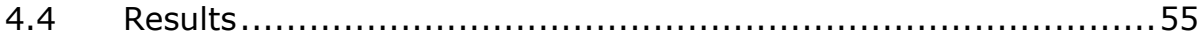

4.5 Discussion: what do access strategies solve for whom? ...............62

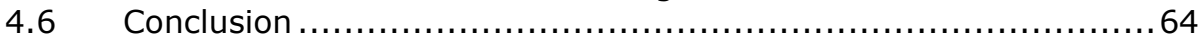

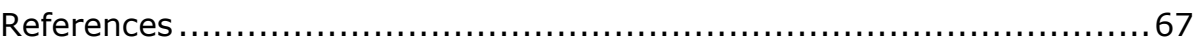

Chapter 5 If citizens protest, do water providers listen? Water woes in a

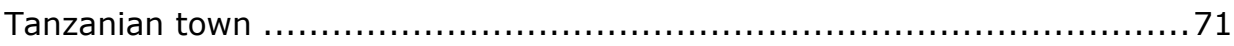

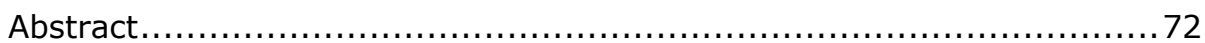

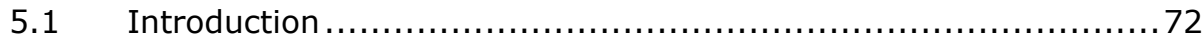

$5.2 \quad$ Empirical Context................................................... 74

5.3 Theoretical approach and methods .................................. 77

5.4 Face-to-face interactions of customers and water officials ...........79

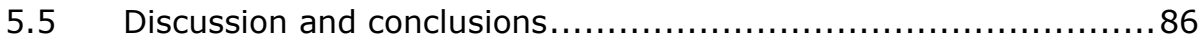

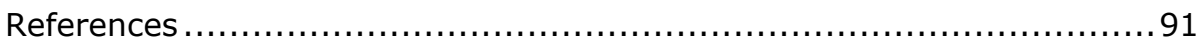

Chapter 6 Formality and informality in rural water supply in Tanzania ........95

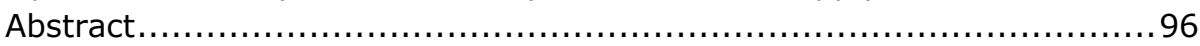




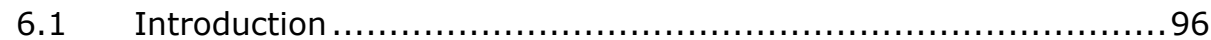

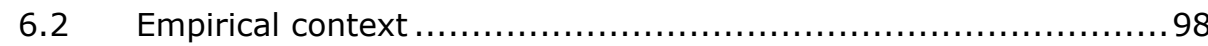

6.3 Conceptual approach and methods .............................. 100

6.4 Perceptions of actors on their own responsibilities and those of others in improving rural water supply ....................... 104

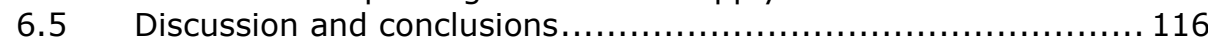

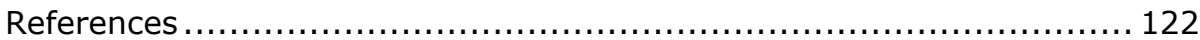

Chapter 7 Working with the grain: How amenable to digital transformation is the monitoring and repair of rural water points in Tanzania? ................ 125

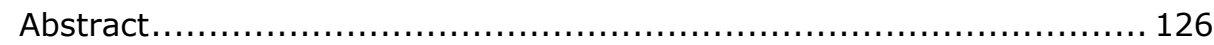

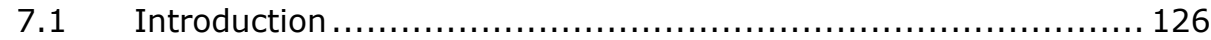

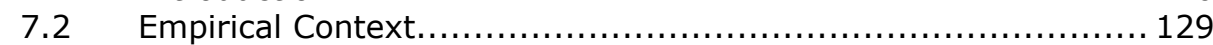

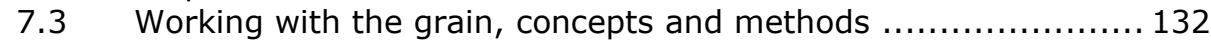

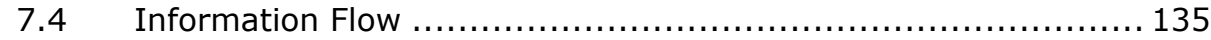

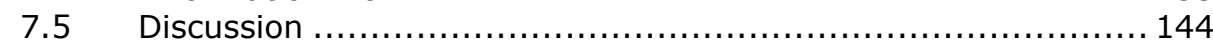

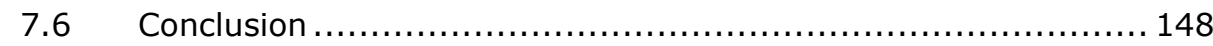

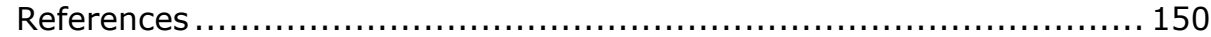

Chapter 8 Epilogue - Working with the community grain in Kilimanjaro ... 153

Introduction .......................................................... 154

8.1 Community-managed rural water supply - still the leading paradigm? .................................................. 154

8.2 Critiques to community management of rural water supply - working with the grain .............................. 155

8.3 The grain of community management in rural water supply in Kilimanjaro............................................. 156

8.4 Community rural water projects in Hai and Siha districts .......... 160

8.5 Interplay between formal and informal institutions................ 168

8.6 Comparing useful informality for sustainable rural water supply. 171

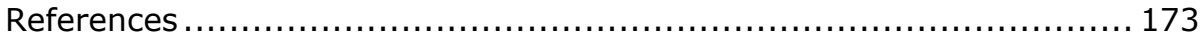

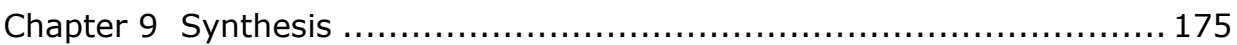

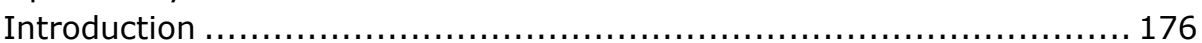

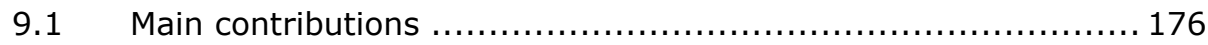

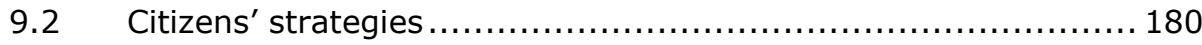

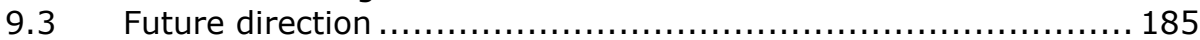

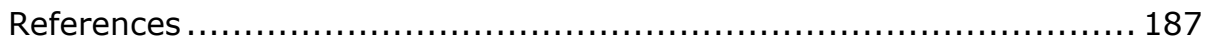

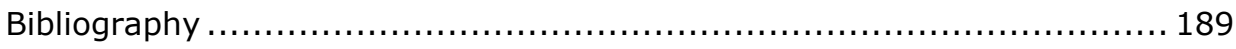

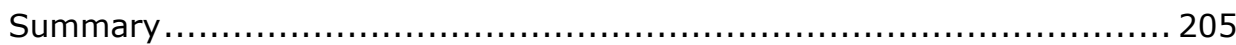

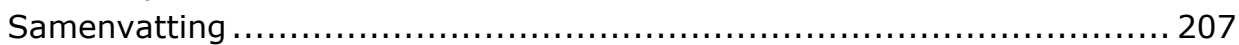

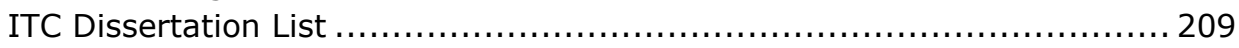




\section{List of figures}

Figure 1.1: Accountability relations in service delivery. Source: World Bank

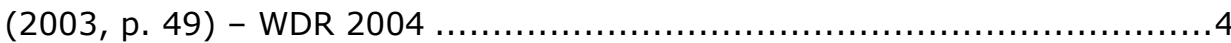
Figure 1.2: Mobile-cellular subscription per 100 inhabitants. Source: ITU

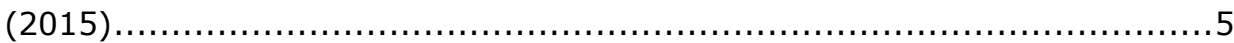

Figure 5.1: Potential customer responses to a service providers' decline. Source: Adapted from Keeley and Graham (1991). ............................ 78 Figure 5.2: Voice and exit: protest strategies of customers to failing urban

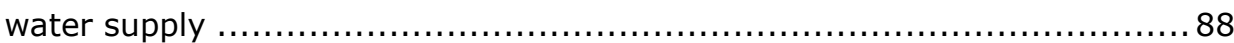
Figure 5.3: Responses of MUWSA officials to protest strategies of customers

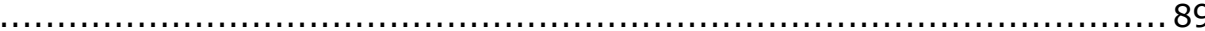

Figure 7.1: Extract of paper form containing water points ................... 128

Figure 7.2: Summary of COWSO characteristics.............................. 132

Figure 7.3: Amenability to improvement through digitization ................ 134

Figure 7.5: Levels of discretion ............................................... 145

Figure 7.6: Amenability to digitization ....................................... 147

Figure 7.7: Steps and tasks in the information flow ........................... 149

Figure 9.1: Relations of local actors in water services. Adapted from (World

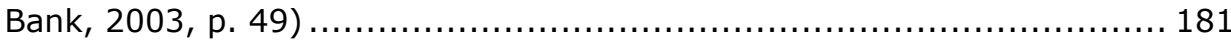




\section{List of tables}

Table 1.1: Historical account on the roles of citizens........................ 10

Table 2.1: Connection between Concepts and Research Questions........... 28

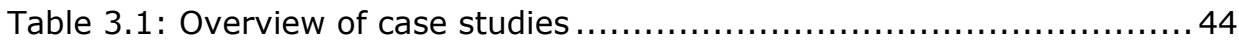

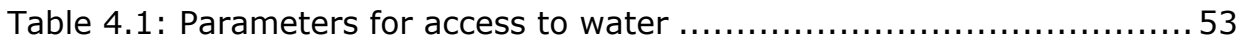

Table 4.2: Price of water in the selected case study areas $\ldots \ldots \ldots \ldots \ldots \ldots \ldots \ldots \ldots$

Table 4.3: Access strategies, citizen categories and dimensions of access... 61

Table 4.4: Access strategies, sources of water, uses and intermediaries ..... 62

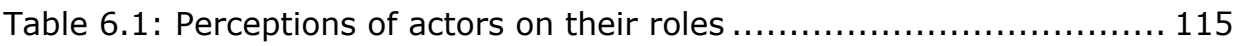

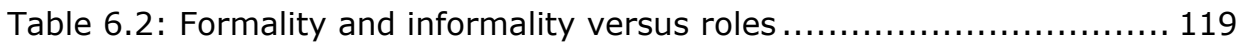

Table 6.3: Comparison between useful/useless informality to citizens ...... 120

Table 8.1: Comparing useful informality for citizens ..................... 172 
Chapter 1

Introduction 


\subsection{Water access in Sub-Saharan Africa}

Almost half of the total global population without access to improved drinking water is in Sub-Saharan Africa. Between 1990 and 2015, the region registered an increase of 20 percent in the use of improved sources of drinking water, but without meeting the Millennium Development Goal (MDG) target (UNICEF/WHO, 2015b). Yet, access to an improved water source does not always guarantee adequate and affordable provision. These figures are likely to worsen given the new more demanding definition for access to water, introduced by the Sustainable Development Goals (SDGs), which include aspects of universality, affordability and equity (WHO-UNICEF, 2015) .

The effects of lack of clean water and access to adequate sanitation are widespread. Children die from dehydration and malnutrition, due to diarrheal illnesses that could be prevented by clean water and good hygiene (Metwally et al., 2006). Diseases such as cholera spread rampantly during the wet season. Diarrheal morbidity and malnutrition for children under five years is severe. Recent studies have shown that diarrheal infections, mainly caused by the use of unsafe drinking water, were responsible for approximately 2.2 million deaths in 2001, while two people out of five lack drinking water in SubSaharan Africa (Ntouda et al., 2013). Women and young girls, the major actors in accessing and carrying water, are prevented from income-generating work or attending school, as the majority of their day is spent walking miles for their daily water needs. They are also at an increased risk of violence when they must walk long distances from their villages on a daily basis to fetch water, or go to the edge of the village to find a private place to relieve themselves.

The dismal state of water access in Sub-Saharan Africa is not the result of lack of interventions, but rather a failure to devise effective approaches in solving the problems facing the sector. Improving access to safe drinking water has been a priority for many countries particularly in the post-colonial period. Development organisations such as NGOs, donors and development banks have been actively supporting efforts for improving access to safe drinking water, ever since the United Nations proclaimed the period from 1981 to 1990 as the first International Drinking Water Decade, an appeal to support for clean and safe drinking water for everybody by 1990 (United Nations, 1977).

In the 1970 s and early 1980 s, many countries in the region adopted a stateled urban water supply (Chowns, 2014). Citizens were considered passive beneficiaries and were less involved in the design, construction and management of water schemes. National governments were responsible for all capital and operational costs of water schemes. Many countries succeeded to register improvements in access to safe and clean drinking water, however, the achievements did not last long. In the late 1980s, economic recession hit the region and affected negatively the capacity of governments to provide 
public services, including water supply. Since the early to mid-1990s, many countries in the region undertook broad reforms of their water service delivery as a response to requirements from international lending institutions to implement structural adjustment programs that aimed to stabilize their economies (Mwanza, 2001).

Within urban water supply, these reforms mainly focused on privatization and the introduction of private sector management approaches aspiring to efficiency, effectiveness, financial sustainability and cost recovery. This shift resulted in studies aiming to measure citizens' willingness to pay for water (Whittington et al., 1991). Citizens were considered customers of water supply and access was determined by their ability and willingness to pay for services. Water changed from a public to a private good. The running costs for water supply became the responsibility of water utilities and were covered from the income collected from users. Many countries, including Tanzania, have had difficulties privatizing urban water utilities. For instance, Pigeon (2012) found in his landmark study that the private management of city water supply in Dar es Salaam did not improve service delivery.

Within rural water supply, interventions in Sub-Saharan Africa evolved from government to community-managed service delivery. Similar to urban water supply, government-led service delivery was considered incapable of ensuring effective operation and maintenance of rural water schemes, mostly hand pumps. Reforms focused on shifting the responsibility to citizens under a new regime of decentralization and community participation (Chowns, 2015). Citizens were given full responsibility and were expected to participate directly in the design, management and monitoring of rural water schemes.

\subsubsection{Making services work for the poor}

The influential World Development Report (WDR 2004 [sic]), titled 'Making Services Work for the Poor' (World Bank, 2003), put citizens/clients on the map together with two other main actors in service delivery, the state (politicians/policy makers) and service providers (frontline and organisations) (Figure 1.1).

Clients are individuals or households who are direct paying beneficiaries of public services (water, health, education). Citizens participate in political processes, pay taxes and vote their representatives ("voice"), and may be either poor or non-poor. The state includes politicians, e.g. prime ministers, presidents, parliamentarians, mayors and ministers, who have the power to regulate, legislate, tax and discharge the fundamental responsibilities of the state, as well as policymakers. While it is often difficult to draw a line between politicians and policy makers, policy makers are the highest non-elected officials of government, e.g. civil servants and appointees responsible for 
setting operational rules to service providers by regulating entry, enforcing standards, and determining conditions under which providers receive public funds ("compact"). Providers are the third actor in the chain of service delivery. The report distinguishes organizations, such as urban water authorities, or hospitals, from frontline providers, such as water officials, doctors or nurses, because the latter often work at the point of service delivery and thus have direct interaction with the clients of the service.

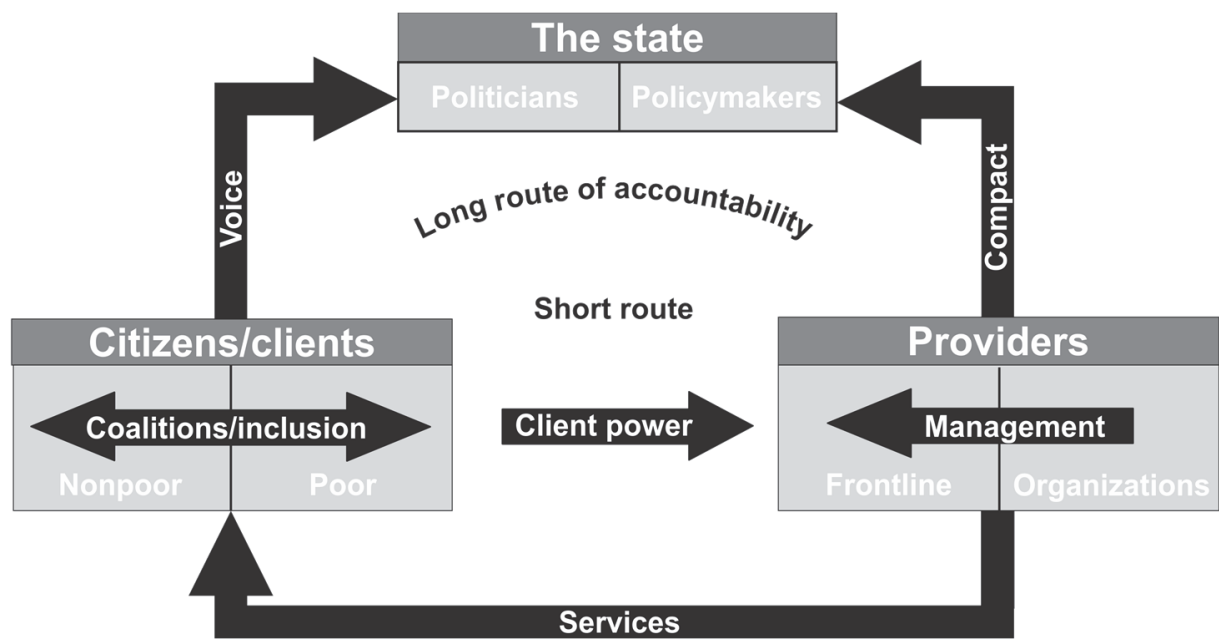

Figure 1.1: Accountability relations in service delivery. Source: World Bank (2003, p. 49) - WDR 2004

The World Development Report 2004 deconstructed the myth that providing better services for the poor is a technical problem that can be solved by building schools, clinics, and water points. Instead, it emphasized that absentee teachers and nurses and broken standpipes is a governance problem and is due to failures in the chain of accountability that links service providers to citizens/clients. The famous "accountability triangle" in Figure 1.1, links citizens/clients to service providers via two routes: the 'long-route' of accountability, which passes through policymakers, and the 'short-route' which is direct. The "long-route" of accountability renders politicians/policy makers more accountable to poor people and service providers more accountable to politicians/policy makers. The "short-route" of accountability makes service providers more accountable directly to the poor. As Kelsall (2016) argues, millions of dollars have been poured since the WDR 2004 report into public sector reform, strategies to improve "compacts" between policy-makers and service providers and electoral support to amplify citizen "voice" on the "longroute", as well as into participatory budgeting and community scorecards on the "short-route" of accountability. 
The base of the triangle, the "short route", caught the imagination of technologists, who thought that it could be strengthened by information and communication technology (ICT) platforms based on mobile phones to enhance "client power" (Champanis \& Rivett, 2012; Georgiadou et al., 2011; Jonoski et al., 2012). The reason for the surge of interest especially in mobile phonebased ICT platforms was the rising mobile phone penetration in the developing world to 73.5 subscriptions per 100 inhabitants in Africa alone (Figure 1.2) and in Tanzania to 63 per 100 inhabitants (World Bank, 2015).

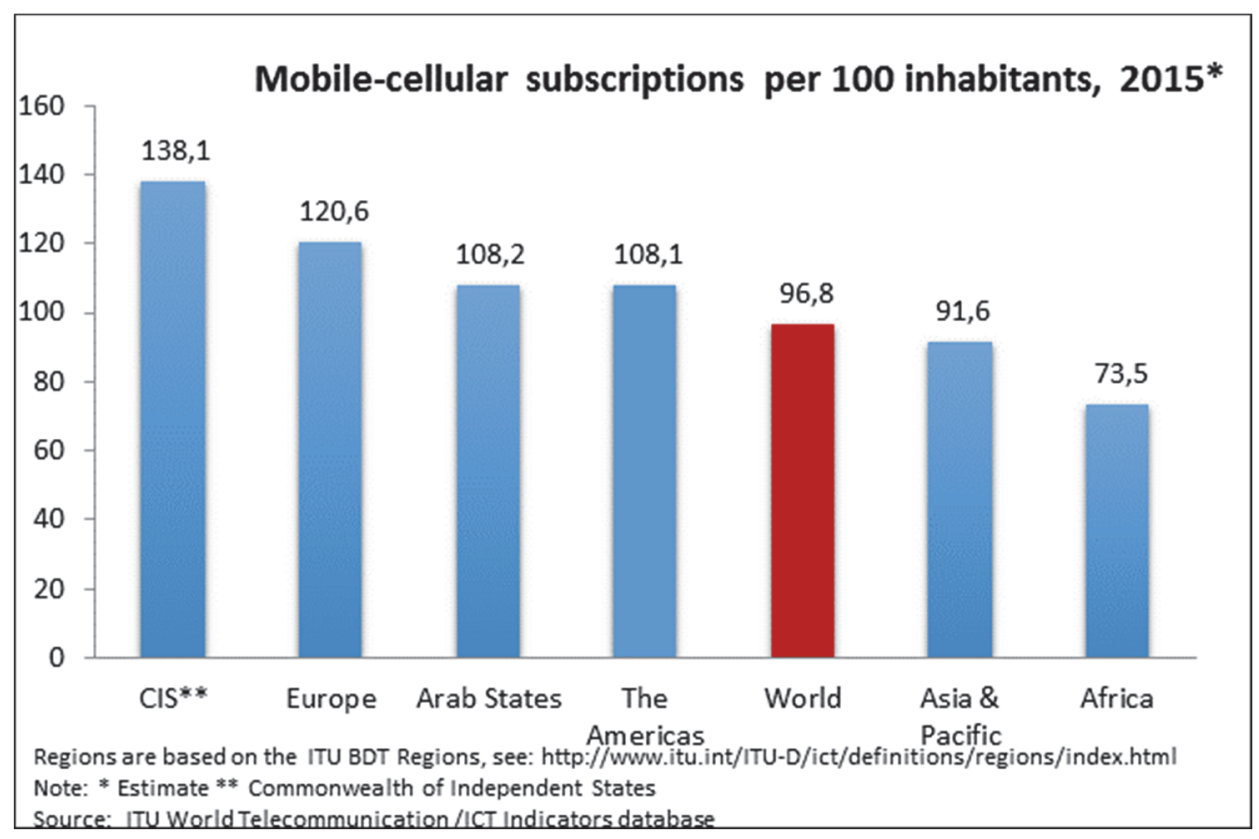

Figure 1.2: Mobile-cellular subscription per 100 inhabitants. Source: ITU (2015)

Several studies compared mobile phone-based ICT platforms for improving services (Ball et al., 2013; Champanis \& Rivett, 2012; M. T. Hutchings et al., 2012; Jonoski et al., 2012). The most recent comparison by Welle et al. (2016) included eight mobile phone-based ICT platforms, all aiming at water services, in three continents. "The scope [...] varies widely. The initiatives [...] differ in their ICT-based reporting methods: while several rely predominantly on crowdsourcing [...] others rely on either the service provider, government or NGO staff collecting data on a regular basis." ( $p .44)$.

In the years after the WDR 2004 report, services continue to fail the poor, particularly with regard to quality. Booth and Cammack (2013), Levy (2014a), Development Research Centre (2010) suggest that this is because of the way in which WDR 2004 has been interpreted and implemented by development practitioners. Almost fifteen years after its publication, the consensus now is that focusing either on the long or the short route of accountability in isolation 
is bound to fail. "[T]he most successful citizen initiatives demonstrate an ability to navigate between the two, and to build both horizontal and vertical alliances for change. Citizen capabilities, political and institutional context, the strength of internal champions, the location of power and decision-making, the history of citizen engagement and the nature of the issue all affect the success or failure of citizen engagement strategies." (Kelsall, 2016, p. 2).

My thesis' point of departure is how citizens/clients affect or not the performance of service providers ("short route"). However, as I moved from one empirical site to the next, I was able to capture elements that are invisible in the "accountability triangle" and include the informal structures of water service provision in Tanzania, and their interplay with formality.

\subsubsection{Water access in Tanzania}

Public water services in Tanzania have failed citizens. Urban coverage and access is now worse than in $1990^{1}$ despite the legal obligation of water utilities to be service-oriented and economically viable. The final Millennium Development Goal (MDG) assessment for Tanzania is "limited or no progress" while the percentage of urban population with piped water dropped from $31 \%$ in 1990 to $28 \%$ in 2015 (UNICEF/WHO, 2015a). ${ }^{2}$ Sarah L. Smiley (2016) concluded that "Tanzania's water landscape is unjust, unequitable and uneven." The population in low income urban areas ${ }^{3}$ is forced to rely on informal providers offering water of uncertain quality at unregulated high prices (Nganyanyuka et al., 2014).

Sustaining functional rural water supply infrastructures has also been a challenge (Giné \& Pérez-Foguet, 2008). Recent studies show that new hand pumps and diesel-powered piped water schemes become non-functional a few years after installation. In Tanzania, nearly half of rural water points are not functional (United republic of Tanzania, 2013c) and about 20\% of newly constructed water points become non-functional within one year. Contributing factors include poor post-construction services (United Republic of Tanzania, 2002b), lack of technical and financial capacity of rural citizens to effectively operate and maintain water projects (Jiménez \& Pérez-Foguet, 2011; Mayo \& Nkiwane, 2013) and lack of reliable access to appropriate and affordable spare parts (Giné \& Pérez-Foguet, 2008; Jiménez \& Pérez-Foguet, 2011). Villagers quickly abandon defunct water schemes, return to traditional, unimproved

\footnotetext{
${ }^{1}$ UNICEF/WHO. (2015). Progress on Sanitation and Drinking Water: 2015 Update and MDG Assessment. United States of America: UNICEF and he World Health Organization. 2 As Satterthwaite (2016) shows, these figures understate the problem as the definition used to measure who uses drinking water sources on premises does not contemplate water quality (water is safe to drink) or "sustainable access" (reliable water supply).

3 It should be noted that aggregate statistics also hide the condition of the most marginalized and low-income communities; see Cheng (2013).
} 
water sources (ponds and streams) and endanger their health and well-being (UNICEF/WHO, 2015a).

The "access to water" definition ${ }^{4}$ of Sustainable Development Goal 6 (SDG 6)"ensure availability and sustainable management of water and sanitation for all" by 2030-will aggravate this problem. SDG 6 extends the MDG focus of "use of an improved source of drinking water" to sustainable management and universal access. The SDG indicator "percentage of population using safely managed drinking water services" refers to the "population using an improved drinking water source which is located on premises, available when needed and free of faecal (and priority chemical) contamination"5 (WHO-UNICEF, 2015). However, accessing water from improved sources "when needed" remains a challenge even for those with piped drinking water on the premises. Furthermore, the principle of universality is undermined when the water authority only listens and responds positively to citizens who are better-off. Monitoring progress towards SDG 6 will probably remain a challenge in lowand middle-income nations. ${ }^{6}$

Failure of water services in Tanzania is a longstanding reality, and so are its causes. To better understand how citizens are prepared to either directly exact accountability from water service providers or take full responsibility in planning, constructing, operating and managing water services, it is imperative to revisit the history of the roles they have played in the water sector in the country. Several authors have written accounts of water supply in Tanzania, however, very few have looked into how the roles of citizens have shifted over time (Madulu, 2000; Mashauri \& Katko, 1993). In this section, I revisit the changes of government approaches in delivering water services and delineate the roles envisaged for citizens in these approaches stretching over three main phases - precolonial, colonial and post-colonial. In describing particular phases, I organise them chronologically to reflect changes in the envisaged roles of citizens which further correspond to water sector institutional progress.

Accounts of water supply in the country during the pre-colonial period are scant. Most of the literature on the history of water in Tanzania came into being with the invasion of colonialists. However, the description of colonialists on the

\footnotetext{
${ }^{4}$ For a critical perspective on water access indicators - what is being counted (how access is defined) and how it is being counted (are data accurate) see Nganyanyuka et al. (2014) and Satterthwaite (2003).

5 The proposed version of February 2015 included "and/or regulated by a competent authority" (United Nations, 2016).

6 Low- and middle-income nations lack adequate data gathering systems to monitor provision for water. When policy mandates targeting under serviced areas, locational information on "who has inadequate provision and where they live" is more relevant than current aggregated indicators at national or city level. See (Satterthwaite, 2003).
} 
state of water supply when they arrived may give us a glimpse of the situation during the pre-colonial phase. Before the colonial era and during the initial period of the colonial era, local communities were organized around chiefs in chiefdoms. Water supply was through wells, rivers and streams. For the most part, women were responsible for fetching water. Men were responsible for digging and constructing wells and/or irrigation channels, which were also used as a source for drinking water.

The history of official water supply in Tanzania dates back to the 1920s when water supply was confined to urban areas and farming settlements owned by settlers. In Dar es Salaam, for instance, "in the European section of the town, each compound obtained water independently by hand-pumps worked by domestic servants. Meanwhile, water vendors supplied African residents with water for domestic use" (Hoag, 2013, p. 231). Within rural areas water supply existed in a few settlements (mostly settler farms) and missionary centres. Water extraction technology included cast iron hand pumps, simple gravity systems and some hand dug wells with bucket and rope. The majority of citizens depended on traditional sources such as hand dug shallow wells, irrigation furrows and rivers. Most of the wells were seasonal, forcing citizens to walk long distances to fetch water, particularly in dry seasons.

\section{Citizens as passive beneficiaries}

Following the country's independence in 1961, the government reclaimed water rights and committed to give free water to citizens (Mashauri \& Katko, 1993), a promise made before independence. In January 1967, the ruling party Tanganyika African National Union (TANU) passed the Arusha Declaration on "Nationalism and Self-Reliance" which stated that all major means of production and exchange were to be owned by the peasants and workers through their government (Freyhold, 1979; Nyerere, 1968). In September 1967, the Declaration was followed by "Socialism and Rural Development" (Ujamaa Vijinini) advocating for the creation of Ujamaa villages, groups of village families working together on communal farms for the common good (Freyhold, 1979). The government introduced public services, such as clean water and schools, to encourage people to join the villages.

\section{Citizens sharing the costs through water fees}

The 1991 water policy introduced cost sharing, whereas citizens would contribute part of the investment through water fees. This was the beginning of the involvement of citizens in the planning, construction, management and maintenance of water projects particularly in rural areas. Donors as well as the government had realized the importance of involving citizens in the management of water supply. The report of a National Workshop for "Village Water Supply and Community Participation in Tanzania" held in Dar es Salaam 
between $14^{\text {th }}$ and $16^{\text {th }}$ July 1981 , stated that "the realization that the needs of the people are most likely to be met if government and external agencies work with the people to meet them" (IRC \& BRALUP, 1982, p. 1). However, the rationale for increased community participation was mainly focused on reducing costs for the implementation and maintenance of projects.

In 2002, the government introduced the National Water Policy (NAWAPO) that among other things shifted to rural citizens the full responsibility for the planning, construction and operation and maintenance of water projects (United Republic of Tanzania, 2002b). On the other hand, the role of the government changed from that of a service provider to that of coordination, policy and guidelines formulation and regulation (United Republic of Tanzania, 2002a). NAWAPO 2002 also introduced demand-driven service delivery approaches and decentralized management of water supplies that give citizens more central role in demanding, implementing and financing water supply services (Jimenez \& Perez-Foguet, 2010). Furthermore, the focus of NAWAPO (2002) has been the promotion of the private sector in the delivery of goods and services around water issues, as the short-lived privatization of water supply utility in Dar es Salaam city in 2003 shows (Pigeon, 2012).

This historical account illustrates that citizens, after being neglected for so long, are now expected to take full responsibility in providing water services. Many of these citizens have never accessed water from an improved source. Nevertheless, they are expected to effectively initiate, plan, construct, manage and operate a water scheme. Others have always found themselves battling between formal and informal providers of water. The role of citizens in water provision has undergone a dramatic and constant shift over the years due to changes in government and/donor approaches to deliver water supply services both to rural and urban citizens. Actually, "the reforms have produced contradictory effects by improving access to water supply for some users, and creating or reinforcing existing inter- and intra-village inequalities" (Masanyiwa et al., 2014, p. 920). Table 1.1 summarizes the history of the roles of citizens in water access in Tanzania. 
Table 1.1: Historical account on the roles of citizens

\begin{tabular}{|c|c|c|}
\hline Period & Rural citizens & Urban citizens \\
\hline $\begin{array}{l}\text { Pre } \\
\text { colonial }\end{array}$ & $\begin{array}{l}\text { Seeking water from traditional water } \\
\text { sources. } \\
\text { Men providing labour in the } \\
\text { construction of water wells } \\
\text { (organized by chiefs) and women } \\
\text { collected water. }\end{array}$ & $\begin{array}{l}\text { Seeking water from traditional water } \\
\text { sources. }\end{array}$ \\
\hline Colonial & $\begin{array}{l}\text { Seeking water from traditional water } \\
\text { sources. }\end{array}$ & $\begin{array}{l}\text { Seeking water in traditional water } \\
\text { sources. } \\
\text { Buying water from private vendors } \\
\text { (in a few selected towns). }\end{array}$ \\
\hline $\begin{array}{l}1961- \\
1970\end{array}$ & $\begin{array}{l}\text { Passive beneficiaries. } \\
\text { Contributing free labour during the } \\
\text { construction of water projects. }\end{array}$ & \\
\hline $\begin{array}{l}1971- \\
1991\end{array}$ & $\begin{array}{l}\text { Passive beneficiaries (getting water } \\
\text { for free at public standpipes). } \\
\text { Working as labourers in the } \\
\text { construction of water projects. }\end{array}$ & $\begin{array}{l}\text { Passive beneficiaries (getting water } \\
\text { for free from standpipes). } \\
\text { Paying customers (household } \\
\text { connections). }\end{array}$ \\
\hline $\begin{array}{l}1991- \\
2000\end{array}$ & Cost sharing (paying fees). & $\begin{array}{l}\text { Paying customers (buying water from } \\
\text { public owned water supply). }\end{array}$ \\
\hline $\begin{array}{l}2002- \\
\text { to date }\end{array}$ & $\begin{array}{l}\text { Contributing part of the cost for new } \\
\text { water projects (free labour or cash). } \\
\text { Full responsibility in the planning, } \\
\text { construction, operation and } \\
\text { management of water projects. } \\
\text { Paying fees/buying water supplied by } \\
\text { Community owned water supply } \\
\text { organizations (COWSOs). }\end{array}$ & $\begin{array}{l}\text { Buying water from private operators } \\
\text { (in practice, however, most water } \\
\text { operators have failed to provide } \\
\text { water adequately). }\end{array}$ \\
\hline
\end{tabular}

\subsection{My personal narrative of access to water in Tanzania}

While the reports and statistics in the preceding section describe the dismal state of water access in Sub-Saharan Africa and its consequences, they do not provide a rich account of how citizens experience their daily struggles to access water. In this section, I present my own experiences with access to water in Tanzania, which not only contributed to the motivation to conduct this research but also inspired the shaping of the research questions. Several issues touched upon in the thesis, such as the exclusion of villagers from water access, their relations to water providers, their protest strategies, and the interplay between formality and informality, are evident in my narrative. Moreover they are correlated with historical events of great magnitude such as the Structural Adjustment Programmes (SAPs), introduced by the International Monetary Fund (IMF) and the World Bank during the 1990s. 
Having been born and living in Tanzania for almost all my life there is no better way to describe the state of water services than by sharing my own struggles in accessing water in rural and urban areas. I use the word "struggle" purposively, as it well illustrates my experiences in accessing potable water. The word "struggle" distinguishes my experience from that of people in the Global North, whose access to water is inconspicuous and taken for granted.

My struggle started even before I could utter the word "water". My mother often recounts an incident of accessing water, when I was just a month old. The incident occurred in Kilwa, a small town in eastern Tanzania where I was born. While the town had piped water supply, it suffered from prolonged periods without water. On one of the water-less days my mother and other people in the town had to fetch water from distant shallow wells. She woke up at dawn to fetch water from a shallow well. Before her arrival at the well, she uttered the word "hodi" to announce her arrival just like a visitor knocking a door to announce his or her entry into a Tanzanian house. The locals believed that anyone approaching a well without uttering the word "hodi" would find the water had turned into blood. Upon reaching the well, she began to fill water into a bucket and as soon as the bucket was full, she noticed a lion about thirty meters away from the well. Having heard countless stories of people being killed and eaten by lions, she was very frightened but she had the courage to put the bucket on her head and started to return home. "I couldn't feel my legs but I don't how I got the bucket on my head. I kept eye contact with the lion and began to move backwards. The notion of going back without water was agonizing. I had very dirty nappies soaked in water overnight. That single bucket of water meant the difference between having dirty and clean nappies. I had no more clean nappies, I had soaked all of them in water" she told me.

When I was six years old, I recall being bitten by bees when I accompanied my fellow kids to fetch water from a river, in a small rural village called Syukula in Rungwe district, Mbeya region, southwest Tanzania. We had relocated to that village when I was just three years old. The main source of water in the village were small ponds dug on the riverbed, just beside the running water. We used to wash clothes and bathe in the same river. In most cases, I accompanied my mother and neighbours when they fetched water. One day I accompanied a group of young children who were going to the river to wash their clothes, take baths and bring water back to their homes. Our trip included children games. On the day of the event, we chose to aim stones at the beehive in one of the trees near the river, which turned out to be very dangerous. The aiming game went well until one "lucky" older kid hit the target, the beehive. Before we knew it, we were all running for our lives climbing the hilly riverbank on our way home. I got a couple of bee stings but I successfully reached home on my own. On reaching home, I was first treated for the bites and then spanked as a punishment for playing dangerous games. No kid died but some were 
hospitalized for days. This story comes up whenever I am asked about my experience in accessing water supply. As much we share the blame for playing a dangerous game, the same goes for the reason that sent us to the bees searching for water. That is why I have always associated this experience with poor access to water. If water had flowed inside our house, I am certain we would have opted for safer games.

After three years in Mbeya, we moved to the Mtwara region, in southern Tanzania. I began primary school and moved to seven different villages in seven years. In each one of the seven villages we fetched water from as far as five kilometres away from home, an average of two hours going and returning. None of the seven villages had a house piped water connection. Carrying water on my head was a usual routine. Later, I lived at my grandparents' village for about three years. Several sources of water ranging from shallow wells, rivers, streams, swamps to hand pumps were available there. The only difference was the distinction between type of water source and kind of use. The sources for drinking water were seasonal shallow wells dug in rice farms, which released a very milky water like the colour of clay soil found in the area. When these wells dried up during the dry season, we were forced to walk to other rice farms in a different valley five kilometres away from home. Until that time, I believed like everyone else in the community that the milkier the water, the better it was suited for drinking, because the milkier the water the more un-salty it was. A hand pump about a half a kilometre from our home had very salty water, which was only used for bathing and cooking purposes and, surprisingly, not for all meals. "If you cook beans with salty water, cooking will take longer and consume more firewood" my grandmother used to say. Water from other sources such as rivers, streams and swamps was used for washing clothes. For better results, there was only one kind of soap that everyone used. A special treat for white clothes, was washing them with the milky water, otherwise, the salty water would turn white clothes brown. Looking back, I now understand how hard it was to make all these decisions. The locals needed a lot of local information to be able to survive amid scarce water supply.

Fast forward to 1993, I was selected to join a boarding secondary school located in a remote area in the same region. My first year at school marked my first experience with piped water supply inside the house. Until that time, I had never experienced piped water inside the house, let alone from a shower. I had already seen in-house piped water in other people's homes when visiting friends, relatives in urban areas, particularly in Dar es Salaam and Mbeya, but these places seemed foreign to me. During my second year at school things changed following the government's removal of subsidies on education thanks to Structural Adjustment Programmes (SAPs) that were introduced by the International Monetary Fund (IMF) and the World Bank during the 1990s. Because of the SAPs, the government abolished subsidies to public schools and 
our school was forced to run only on school fees collected from students. The funds were not enough to run the school particularly in providing adequate food, water and electricity supply among many other services. The school could no longer afford to buy diesel for running a pump used to extract water from a dam three kilometres down the hill. Instead, students became a cheap replacement of the pump. The school administration added "water fetching" to the long list of students' self-reliance activities already filled with farming, fetching firewood and grazing cattle owned by the school. Carrying three buckets of water on our heads three kilometres from the dam up the hill to the school became a daily routine. A bucket became an important item in the instructions to join the school. For all students, it was mandatory to bring a bucket. The change in the source of water also meant a shift from showering in the school bathrooms to taking baths in the river. This shift resulted in students taking less baths and created health risks, especially scabies. When one student who had scabies took a bath in the river countless other students contracted the disease.

Prior to starting my PhD research, I was living in Mbeya, Tanzania, together with my wife and child. Since my PhD included extended periods of fieldwork I would alternate longer periods between Tanzania and the Netherlands, and as a family, we felt it was rational to move to Dar es Salaam. We felt that Dar es Salaam would provide easier access to services particularly health and transport and began to search for accommodation in the city.

Dar es Salaam is the largest city and Tanzanian's economic hub with an estimated population of about five million inhabitants. Huge disparities exist between and within different parts of the city, particularly in terms of access to public services, types of settlements and the residents' socio-economic status. Some of these differences are the result of settlement segregation policies implemented by the German and British colonial governments prior to the country's independence (S. L. Smiley, 2009). A high disparity in access to public services is also evident for water services. Main sources of water include a mix of public piped network, unregulated private water vendors, underground wells and open sources such as shallow wells and rivers. We decided to settle in Sinza, in Kinondoni district, one of the few planned settlements in Dar es Salaam, featuring a mix of very old houses fused with modern high-rise buildings. Famously known as "kwa wajanja", which in Swahili means a place for clever people, Sinza is largely inhabited by young middle class families with small household sizes. The word "wajanja" connotes cleverness, opportunism, and deception as means for survival (my own experiences in Sinza correspond to the deception part of the meaning, as we shall see shortly).

Home search in Dar es Salaam and many other urban areas in Tanzania is usually organised through informal brokers (unregulated). The tenant pays all 
costs involved in securing a house including communication (phone recharge vouchers), transport and an additional fee for the broker, charged for every house shown. I contacted a few brokers and expressed the wish for a house with a reliable access to water as my top priority. Having experienced the water supply in Dar es Salaam in the past (during my undergraduate degree and thereafter for two years), the term "reliable access to water" meant neither a $24 / 7$ supply, nor simply a public piped system. A significant number of people in Dar es Salaam have reliable access to water through private underground wells.

The first house did not have a public piped connection, but a private underground well with a raised tank of about 5000litres. The well was fitted with an electric pump which draws water to the tank. The broker as well as the outgoing tenants told us that the water system was working perfectly although the tank had no water when we inspected it. They told us that the empty tank was due to power cuts. We naively trusted the outgoing tenants' confirmation that the house had running water. Besides the existence of the water tank, the electric pump and pipes inside the house seemed a good proof. Given our dire need to move quickly to Dar es Salaam, we signed a rental contract and moved into the house. To our surprise, the water system in the house was not working. Soon, we found out that the water system had not worked for about three years. In other words, we had been deceived by the broker, the landlord and the outgoing tenants. We had no option to leave the house or break the contract as we had paid the annual rent in advance. The landlord refused to reimburse the rent and we were forced to wait for another twelve months. We resorted to buying water from a mosque, about $400 \mathrm{~m}$ from the house, for a price of 50 Tanzanian shillings for a bucket of 20 litres. Even so, we were paying someone to carry the water to our house and we ended up paying 100 Tanzanian shillings per bucket. We were also forced to buy additional water for drinking purposes since the water from the mosque was salty. Mobile vendors who sold water for drinking purposes bought it from wholesale vendors who had house connections from Dar es Salaam Water and Sanitation Corporation (DAWASCO), the official water supplier in the city. Other private water vendors, some of which were buying water from the mosque, were charging 300 Tanzanian shillings for the same volume of water.

Eventually, I successfully moved to Kijitonyama, a planned settlement adjacent to Sinza, into a house with piped water connection from DAWASCO. During the first month, we received water twice a week, which is common in most parts of the city. We installed storage tanks to be able to have a constant water supply. This was normal and we never complained. However, things changed three months into our stay at the new house. After going for a month without water supply, we complained to the landlord who reported the problem to DAWASCO. DAWASCO water technicians offered a solution to our water woes 
and suggested to settle the issue "unofficially". They offered to transfer the inlet that sent water to our house from the original to another one with supposedly better water supply. The landlord agreed to pay the money and within a few days the pipe was changed and water supply resumed. As promised by DAWASCO water technicians, the new connection allowed us to get water three days a week. The only difference was the source of water, which according to the water technician, was changed from a small to a larger distribution pipe. This was the only illegal part of the deal; the landlord was still a DAWASCO customer and all bills were official. The landlord paid his bills at DAWASCO.

The improvement did not last long. Just two months after the "new deal", we began to experience longer periods without water as opposed to getting water after every three days. The problem intensified to a point where we did not have water for a full month. The landlord decided to contact the usual DAWASCO water technician to find out what went wrong. As usual, the communication was at a personal level, outside official channels. The landlord had kept the phone number of the DAWASCO water technician who had insisted that he should be contacted about any problems. He reached him by phone, however, the technician claimed that he could not help this time - he had been shifted to another water office in the city. Nonetheless, they provided contact details of another DAWASCO water technician who could help, but my landlord had to enter into a new deal.

My landlord contacted the new water technician and struck a new deal to transfer the pipe to another transmission water network. He paid three hundred thousand shillings and the water supply was resumed - this time we received water two times a week and in most cases only at night. The water connection was not inside but outside the house. We used to leave the tap open during the night to be able to hear water when it started to flow. One month before the renewal of my annual rental contract, we experienced another water problem. The landlord wanted me to stay and he promised to drill his own underground water well. He planned to use my rent for the next year as part of the funds for the construction of the water well. I could not agree and decided to move to another house. This time I had learned a few lessons about water supply and was very cautious not to be deceived by a broker or a landlord. Luckily my new landlord had already connected piped water from DAWASCO. I made a few informal visits to the house and found running water each time. When we finally moved to the house we had water again, twice a week as usual.

In 2015, my mother retired from her teaching career and settled in Masasi town, which has about a hundred thousand inhabitants. She spent part of her pension to buy a house in one of the outskirts of the town. The area is planned. 
However, it lacks most of the basic services including piped water, electricity, sewerage system and roads. "I did not want get in trouble with the law, so I went for a planned area", she tells me to justify her decision to buy a house in that part of the town. After settling in, she began the process of connecting her house with piped water provided by Masasi-Nachingwea Water Supply and Sanitation Authority (MANAWASA), the official water supplier in the town. MANAWASA falls under the $C$ category of water utilities in the country (United Republic of Tanzania, 2014). Category C refers to "water utilities with water service coverage of less than 65 percent and meeting operation and maintenance costs except part of plant electricity costs" (ibid, p. 2). In other words, although MANAWASA operates as a corporate entity, it depends on subsidies from the central government to cover part of the operation and maintenance costs such as electricity bills. MANAWASA also supplies water to Nachingwea town, a district capital about $50 \mathrm{~km}$ north of Masasi, with a population of about one hundred thousand people. When my mother approached MANAWASA she was told that the process for a new water connection is simple and straightforward. First, she would fill the application form, then MANAWASA would survey the area and provide an estimate of the costs for the application fees and connection charges (including equipment such as pipes, taps) and finally, MANAWASA would connect water within 14 working days.

The process did not end as positively as my mother anticipated, although the beginning was promising. The same day she submitted the application form, she returned home accompanied by a surveyor from MANAWASA who surveyed the area and took measurements. The results of the survey were distressing. According to the survey report, my mother's house is outside MANAWASA's piped network area and thus it was not possible to connect water for the normal cost. Specifically, the house is one kilometre away from the nearest MANAWASA distribution network. My mother would have to finance the pipes, stretching over one kilometre distance, at an exorbitant cost, which she could not afford. As a consolation, one of the MANAWASA technicians suggested that my mother should mobilize her neighbours to contribute to the costs. In this way, the costs would be shared among neighbours and everyone would win by getting a house connection at a reduced cost. The technician missed that i) my mother had no intention or resources for mobilizing neighbours, and ii) the time it would take to mobilize funds from a heterogeneous community of people with different interests and economic levels. My mother decided to wait until MANAWASA expanded its distribution network, which according to its director, would happen soon. One thing is certain, my mother is excluded from the official water supply although her house is in a formal settlement. This means she has to depend on buying water from private and informal providers whose quality is often not guaranteed. What is not certain however, is how long she will have to wait until the government provides the funds for the 
expansion of the MANAWASA's distribution network (and possibly water production as well).

These are just a few of the many memorable experiences that demonstrate my struggles to access to water over the years in rural and urban Tanzania. The struggles are not over. During my fieldwork for this thesis, in April 2015, I was diagnosed with typhoid and was forced to terminate my field data collection. My experiences are typical for countless other Tanzanians and Sub-Saharan Africans accessing drinking water. These struggles are an integral part of our daily lives in Sub-Saharan Africa as opposed to other parts of the world with better piped water supply. They affect our daily decision making including the games we play as children, how we select a house to rent, which soap we buy and the type of food we eat. In the next section, I present how the development community hopes that the rising mobile phone penetration in Africa and ICT could positively influence citizens' struggles to access water services.

\subsection{The potential of ICT and mobile phone-based platforms}

Recent developments in information and communication technologies (ICT), particularly the rising diffusion of mobile phones in Sub-Saharan Africa, have raised hopes among development practitioners and researchers on the potential for leveraging technology towards improving access to safe and clean drinking water and public services in general. ICT was hailed for its potential to expand transparency and accountability (Avila et al., 2010), as well as to improve service delivery (Bhatnagar, 2014; Visser \& Twinomurinzi, 2008). Well-designed ICTs and mobile phone-based platforms are expected to offer better mechanisms for collection, manipulation, presentation, dissemination and republication of information. ICT and mobile phone-based interventions offer opportunities for a quick and more affordable mechanism for two-way communication between citizens and service providers or governments. In general, technology is considered to have the potential to transform water service delivery by creating more effective and easy ways for governments and service providers to share information. Several such platforms have been deployed and compared for a variety of key services in various countries in the global South (e.g. Fung et al., 2010a; Fung et al., 2010b; Georgiadou et al., 2013; McGee \& Gaventa, 2010; Welle et al., 2016).

Tanzania has witnessed an increase in mobile phone adoption and usage (from $10 \%$ in 2002 to $73 \%$ in 2015) (ITU, 2015). The proliferation of mobile phone penetration has attracted donors, researchers and development practitioners in designing and deploying mobile phone applications aimed at strengthening citizens' voices to service providers and/or the state (Pearce et al., 2013; Welle et al., 2016; Williams et al., 2016). Twaweza's Sauti za Wananchi (Voices of 
Citizens) program uses mobile phones to regularly collect information from a broad cross-section of Tanzanian citizens (Twaweza, 2013).

Governments often take a leading role in ICT adoption (World Bank, 2016), an excellent example being the MajiVoice platform in Kenya. Government institutions have adopted the idea of using mobile phones as a tool for service delivery and a way to communicate with the citizens. Some of the challenges have been on how to encourage mass participation of citizens in using mobile phones and mobile phone applications. Widespread mobile phone penetration has also improved ordinary people's ability to participate in media production and broadcasting through use of text messaging and phone-in programmes, thus increasing their power to voice their concerns. Not long ago, rural radio stations interacted with their listeners in two main ways: face-to-face visits either at the radio station or in the community - and through letters sent by listeners. Mobile phones have overcome various challenges of these conventional means of interactions between citizens and radio stations including i) poor transportation to and from remote communities especially during the rainy season, and ii) slowness and unreliability of sending letters. The radio has proven an important medium for development, from teaching farmers in rural areas new farming methods (Myers, 2010), to transferring information to farmers about prices of farm outputs, to creating awareness about proper health and hygiene behaviours. In the case of water, some initiatives attempted to introduce the use of mobile phones to encourage citizens reporting problems of water to local government officials (Taylor, 2012d; Welle et al., 2016).

\subsection{Knowledge gap}

Literature on the design and adoption of mobile-based information and communication technologies for improving service delivery has emphasized ICT while giving lesser emphasis on understanding extant behavioural patterns and strategies of citizens and clients of public services. Several authors have discussed and compared such platforms for water supply (Ball et al., 2013; Champanis \& Rivett, 2012; M. T. Hutchings et al., 2012; Jonoski et al., 2012). The most recent comparison by Welle et al. (2016) surveyed eight platforms, all aiming at water services, in three continents, including two failed platforms in Tanzania. However, these studies either explain the failure in hindsight (an autopsy of sorts) or success of a platform (Welle et al., 2016) or hide patterns of local variation in homogenized national averages of cross-national comparisons (Fox, 2015). The process, the "how to", is missing.

I argue for "working with the grain" (Booth, 2012; Levy, 2014b) of citizens' relations with water providers. This entails first understanding the problems within the water sector from the point of view of participants and then exploring 
options for solving the problem. Against this background, my research sets out to understand the factors that affect existing citizens' strategies in improving access to water, in both urban and rural areas, and then considering incremental ways of amplifying these strategies with mobile phone-based platforms. At the heart of my research are citizens' strategies nudging (or not) water providers to perform better (Kochendörfer-Lucius \& Pleskovic, 2004). Only then, can the potential of mobile phone-based ICT platforms to further amplify these strategies be meaningfully considered. Effective mobile-phone based ICT platforms do not work against citizens' relations with water providers but are typically effective when they operate through them (Fung et al., 2011), when they "work with the grain" of these relations. As Toyama (2016) argued, citizens' "voice, not the technology, is the primary cause of change." (p. 30).

\subsection{Research questions}

The thesis has a main research question and five sub-questions that parse the main question into smaller empirical and conceptual units.

Main research question

Which factors affect citizens' strategies to improve access to water services and how?

\section{Sub-questions}

1. What do official statistics on access to urban water services reveal and/or conceal?

2. Which strategies do citizens use to protest substandard water services and to what effects?

3. How do local actors perceive their own responsibilities and those of other actors and to what extent can a mobile phone-based platform improve rural water services?"

4. How can ICTs play a role in the monitoring by citizens of water services?

\subsection{Framing the thesis within the SEMA research project}

My thesis is part of the Sensors Empowerment and Accountability (SEMA) project, an integrated research of the University of Twente and the University of Dar es Salaam, funded by NWO-Wotro Science for Global Development. SEMA is a Swahili word, which means "tell me". A central research tool of the project is a political mobile phone-based app, called SEMA, that citizens, as human sensors of grievances, may use (or not) to report to government their grievances about access to public services, particularly water. The project aims to find out to what extent ordinary citizens in Tanzania can directly demand accountability from water and public health providers with political apps. 
SEMA builds on the lessons learned from a pilot project conducted by the University Twente designed to support the reports sent by citizen-consumers of water point failure by means of a SMS-based platform (called the Human Sensor Web - HSW). The project was implemented in Zanzibar in the years 2009-2010. A Human Sensor Web (HSW) was defined as an assembly of the following elements: geographic web services, citizens with mobile phones ("human sensors") reporting \& publicizing water and health problems in appropriate combinations of traditional and novel media (including Google Maps), public water points \& clinics, and stakeholders \& users. The failed implementation of the HSW project in Zanzibar brought up three key lessons. First, there is a gender mismatch between the mobile phone owners (usually men) and those who fetch the water from the public water points (usually women). Second, community loyalty may override the urgency of reporting the grievance. Community (shehia) members are loyal to their leader (sheha) and may refrain from using the human sensor web unless the community leader endorses it (Yusra, 2011). Third, distrust towards the water authority runs deep in some communities, due to the water authority's history of not responding to citizens' grievances in a timely fashion.

Prior to my selection for the PhD position, I had gathered personal experience on the Maji Matone project (www.daraja.org). Maji Matone was designed to encourage and empower rural citizens to report problems of water to local government officials in the hope that the latter would respond and fix the problems. The project was implemented as a pilot in three rural Tanzanian districts between 2009 and 2013 and equally failed to produce the coveted SMS reports by citizen-consumers. The reasons were i) technology is only a small part of the problem, rural water supply deals with institutions, responsibilities, legal frameworks and money flows, ii) it was difficult to persuade citizens to engage (report water problems), iii) rural women who are largely responsible for collecting water had poor access to mobile phones, and iv) rural citizens use their phones much more for voice calls than for SMS (Taylor, 2011a, 2012a, 2012b, 2012c). My experience with Maji Matone and particularly the challenges in attracting mass participation of citizens was my motivation for applying for the PhD position in the SEMA project and for investigating this issue further. 


\section{References}

Avila, R., Feigenblatt, H., Heacock, R., \& Heller, N. (2010). Global Mapping of Technology for Transparency and Accountability: New Technologies. London, UK: Transparency \& Accountability Initiative c/o Open Society Foundation.

Ball, M., Rahman, Z., Champanis, M., Rivett, U., \& Khush, R. (2013). Mobile data tools for improving information flow in WASH: Lessons from three field pilots. Bristol, UK: Aquatest Research Programme, University of Bristol.

Bhatnagar, S. (2014). Public service delivery: Role of information and communication technology in improving governance and development impact. Manila: Asian Development Bank.

Booth, D. (2012). Working with the Grain and Swimming against the Tide. Public Management Review, 14(2), 163-180. doi: 10.1080/14719037.2012.657959

Booth, D., \& Cammack, D. (2013). From 'good governance' to governance that works Governance for development in Africa: Solving collective action problems. London: Zed Books.

Champanis, M., \& Rivett, U. (2012). Reporting water quality: a case study of a mobile phone application for collecting data in developing countries. Paper presented at the Proceedings of the Fifth International Conference on Information and Communication Technologies and Development, Atlanta, Georgia. http://dl.acm.org/citation.cfm?doid=2160673.2160688

Cheng, D. (2013). (In)visible urban water networks: the politics of nonpayment in Manila's low-income communities. Environment and Urbanization, 25(1), 249-260. doi: 10.1177/0956247812469926

Chowns, E. (2014). The political economy of community management: a study of factors influencing sustainability in malawi's rural water supply sector. (PhD thesis), University of Birmingham, Birmingham, UK.

Chowns, E. (2015). Is Community Management an Efficient and Effective Model of Public Service Delivery? Lessons from the Rural Water Supply Sector in Malawi. Public Administration and Development, 35(4), 263-276. doi: 10.1002/pad.1737

Development Research Centre. (2010). Blurring the boundaries: Citizen action across states and societies. Brighton: Institute for Development Studies.

Fox, J. A. (2015). Social Accountability: What Does the Evidence Really Say? World Development, 72, 346-361. doi: http://dx.doi.org/10.1016/j.worlddev.2015.03.011

Freyhold, M. v. (1979). Ujamaa Villages in Tanzania: Analysis of a Social Experiment. London: Heinemann Educational Books Ltd.

Fung, A., Gilman, H. R., \& Shkabatur, J. (2010a). Impact Case Studies from Middle Income and Developing Countries. Cambridge, MA: Transparency \& Accountability Initiative. c/o Open Society Foundation. 
Fung, A., Gilman, H. R., \& Shkabatur, J. (2010b). Technologies of Transparency for Accountability: An Examination of Several Experiences from MiddleIncome and Developing Countries.

Fung, A., Gilman, H. R., \& Shkabatur, J. (2011). Why technology hasn't revolutionized politics. Program on Liberation Technology. CDDRL, Program on Liberation Technology News. Retrieved 5th January, 2013

Georgiadou, Y., Bana, B., Becht, R., Hoppe, R., Ikingura, J., Kraak, M.-J., Lance, K., Lemmens, R., Lungo, J. H., McCall, M., Miscione, G., \& Verplanke, J. (2011). Sensors, empowerment, and accountability: a Digital Earth view from East Africa. International Journal of Digital Earth, 4(4), 285-304. doi: 10.1080/17538947.2011.585184

Georgiadou, Y., Lungo, J. H., \& Richter, C. (2013). Citizen sensors or extreme publics? Transparency and accountability interventions on the mobile geoweb. International Journal of Digital Earth, 1-18. doi: 10.1080/17538947.2013.782073

Giné, R., \& Pérez-Foguet, A. (2008). Sustainability assessment of national rural water supply program in Tanzania. Natural Resources Forum, 32(4), 327342. doi: $10.1111 /$ j.1477-8947.2008.00213.x

Hoag, D. H. J. (2013). Developing the Rivers of East and West Africa: An Environmental History. London \& New York: Bloomsburry.

Hutchings, M. T., Dev, A., Palaniappan, M., Srinivasan, V., Ramanathan, N., \& Taylor, J. (2012). Mobile Phone Applications for the Water, Sanitation, and Hygiene (WASH) Sector. Los Angeles, California: Pacific Institute.

IRC, \& BRALUP. (1982). Village Water Supply and Community Participation in Tanzania: Report of a National Workshop held in Dar es Salaam, Tanzania, July 14-16, 1981. The Hague, The Netherlands: International Water and Sanitation Centre (IRC) \& Bureau of Resource Assessment and Land Use Planning.

ITU. (2015). ICT Facts \& Figures. The world in 2015. https://www.itu.int/en/ITU-

D/Statistics/Documents/facts/ICTFactsFigures2015.pdf

Jimenez, A., \& Perez-Foguet, A. (2010). Building the role of local government authorities towards the achievement of the human right to water in rural Tanzania. Natural Resources Forum, 34(2), 93-105.

Jiménez, A., \& Pérez-Foguet, A. (2011). The relationship between technology and functionality of rural water points: evidence from Tanzania. Water Science and Technology, 63(5), 948-955. doi: 10.2166/wst.2011.274

Jonoski, A., Alfonso, L., Almoradie, A., Popescu, I., van Andel, S. J., \& Vojinovic, Z. (2012). Mobile Phone Applications in The Water Domain. Environmental Engineering and Management Journal, 11(5), 919-930.

Kelsall, T. (2016). Governance and Service Provision. Professional Development Reading Pack No. 38. University of Birmingham. Birmingham, UK. Retrieved from http://www.gsdrc.org/wpcontent/uploads/2016/04/Governance-and-service-provision_RP.pdf 
Kochendorfer-Lucius, G., \& Pleskovic, B. (Eds.). (2004). Service Provision for the Poor: Public and Private Sector Cooperation. Washington, DC.: World Bank.

Levy, B. (2014a). Function versus form in public sector reform Working with the grain: Integrating governance and growth in development strategies. New York: Oxford University Press.

Levy, B. (2014b). Working with the Grain: Integrating Governance and Growth in Development Strategies. New York: Oxford University Press.

Madulu, N. F. (2000). Changing Water Needs and Uses in Rural Communities of Mwanza Region, Tanzania. Paper presented at the 1st WARFSA/WaterNet Symposium: Sustainable Use of Water Resources; 12 November 2000, Maputo, Mozambique. http://www.waternetonline.ihe.nl/downloads/uploads/symposium/moza mbique-2000/MADULU.PDF

Masanyiwa, Z. S., Niehof, A., \& Termeer, C. J. A. M. (2014). Users' perspectives on decentralized rural water services in Tanzania. Gender, Place \& Culture, 22(7), 920-936. doi: 10.1080/0966369X.2014.917283

Mashauri, D. A., \& Katko, T. S. (1993). Water-Supply Development and Tariffs in Tanzania - From Free-Water Policy towards Cost Recovery. Environmental Management, 17(1), 31-39. doi: 10.1007/bf02393792

Mayo, A. W., \& Nkiwane, L. (2013). The role of community participation on cost recovery and sustainability of rural water supply projects in Hai District, Tanzania. Journal of Environmental Science and Water Resources, 2(11), 388 - 395.

McGee, R., \& Gaventa, J. (2010). Review of Impact and Effectiveness of Transparency and Accountability Initiatives: Synthesis Report. London, UK: Institute of Development Studies.

Metwally, A. M., Ibrahim, N. A., Saad, A., \& Abu El-Ela, M. H. (2006). Improving the roles of rural women in health and environmental issues. International Journal of Environmental Health Research, 16(2), 133-144. doi: $10.1080 / 09603120500539208$

Mwanza, D. D. (2001). Reforming Africa's water and sanitation sector: Issues and challenges. Loughborough: Water Engineering \& Development Centre.

Myers, M. (2010). Why Radio Matters: Making the case for radio as a medium for development. Washington DC: Developing Radio Partners.

Nganyanyuka, K., Martinez, J., Wesselink, A., Lungo, J. H., \& Georgiadou, Y. (2014). Accessing water services in Dar es Salaam: Are we counting what counts? Habitat International, 44, 358-366. doi: http://dx.doi.org/10.1016/j.habitatint.2014.07.003

Ntouda, J., Sikodf, F., Ibrahim, M., \& Abba, I. (2013). Access to drinking water and health of populations in Sub-Saharan Africa. Comptes Rendus Biologies, 336(5-6), 305-309. doi: http://dx.doi.org/10.1016/j.crvi.2013.06.001 
Nyerere, J. K. (1968). UJAMAA: Essays on Socialism. Dar es Salaam: Oxford University Press.

Pearce, J., Welle, K., \& Dickinson, N. (2013). Information and Communication Technologies (ICTs) for monitoring sustainable service delivery. The Hague, The Netherlands: IRC.

Pigeon, M. (2012). From Fiasco to DAWASCO: Remunicipalising Water Systems in Dar es Salaam, Tanzania. In M. Pigeon, D. A. McDonald, O. Hoedeman \& S. Kishimoto (Eds.), Remunicipalisation: Putting Water Back into Public Hands. Amsterdam, The Netherlands: Transnational Institute.

Satterthwaite, D. (2003). The Millennium Development Goals and urban poverty reduction: great expectations and nonsense statistics. Environment and Urbanization, 15(2), 179-190. doi: $10.1177 / 095624780301500208$

Satterthwaite, D. (2016). Missing the Millennium Development Goal targets for water and sanitation in urban areas. Environment and Urbanization, 28(1), 99-118. doi: 10.1177/0956247816628435

Smiley, S. L. (2009). The city of three colors: Segregation in colonial dar es salaam 1891-1961. Historical Geography, 37, 178-196.

Smiley, S. L. (2016). Water Availability and Reliability in Dar es Salaam, Tanzania. The Journal of Development Studies, 1-15. doi: 10.1080/00220388.2016.1146699

Taylor, B. (2011a). Maji Matone hasn't Delivered. Time to embrace failure, learn and move on Daraja Blog (Vol. 14/07/2012). Njombe: Daraja Development Ltd.

Taylor, B. (2012a). Why did Maji Matone fail? 1. Low-tech obstacles to hightech solutions? Retrieved from http://blog.daraja.org/2012/02/why-didmaji-matone-fail-1-low-tech.html

Taylor, B. (2012b). Why Did Maji Matone Fail? 2. The World of Water Supply? Retrieved from http://blog.daraja.org/2012/02/why-did-maji-matonefail-2-world-of.html

Taylor, B. (2012c). Why Did Maji Matone Fail? 3. Citizens' Engagement, Risk and Apathy? Retrieved from http://blog.daraja.org/2012/02/why-didmaji-matone-fail-3-citizens.html

Taylor, B. (2012d). Why Did Maji Matone Fail? 3. Citizens' Engagement, Risk and Apathy? Daraja Blog (Vol. 2012). Njombe: Daraja Development Ltd.

Toyama, K. (2016). Global computing: Internet and inequality. Communications of the ACM April 2016, 59(4), 28-30.

Twaweza. (2013). Sauti za Wananchi: Collecting national data using mobile phones. Dar es Salaam, Tanzania: Twaweza.

UNICEF/WHO. (2015a). Progress on Sanitation and Drinking Water: 2015 Update and MDG Assessment. Geneva: UNICEF and the World Health Organization. 
UNICEF/WHO. (2015b). Progress on Sanitation and Drinking Water: 2015 Update and MDG Assessment. United States of America: UNICEF and The World Health Organization.

United Nations. (1977). Report of the United Nations Water Conference, Mar del Plata, March 14- 25, 1977. New York: United Nations.

United Nations. (2016). Goal 6: Ensure access to water and sanitation for all. Retrieved 19 September, 2016, from http://www.un.org/sustainabledevelopment/water-and-sanitation/

United Republic of Tanzania. (2002a). National Water Policy. Dar es Salaam: United Republic of Tanzania.

United Republic of Tanzania. (2002b). National Water Policy 2002. Dar es Salaam, Tanzania.

United republic of Tanzania. (2013c). The water sector status report 2013. Dar es Salaam, Tanzania: Ministry of Water.

United Republic of Tanzania. (2014). The Water Sector Status Report 2014: Marking the End of WSDP Phase-I. Dar es Salaam, Tanzania: Ministry of Water.

Visser, W., \& Twinomurinzi, H. (2008). E-Government \& Public Service Delivery: Enabling ICT to put "People First" - A Case Study from South Africa.

Welle, K., Williams, J., \& Pearce, J. (2016). ICTs Help Citizens Voice Concerns over Water - Or Do They? IDS Bulletin, 47(1), 41-51. doi: http://dx.doi.org/10.19088/1968-2016.105

Whittington, D., Lauria, D. T., \& Mu, X. (1991). A study of water vending and willingness to pay for water in Onitsha, Nigeria. World Development, 19(2), 179-198. doi: http://dx.doi.org/10.1016/0305-750X(91)90254-F

WHO-UNICEF. (2015). Methodological note: Proposed indicator framework for monitoring SDG targets on drinking water, sanitation, hygiene and wastewater.

Williams, J., Welle, K., \& Pearce, J. (2016). How can ICT initiatives be designed to improve rural water supply? Brighton: IDS and WaterAid.

World Bank. (2003). World Development Report 2004: Making Services Work for the Poor. Washington, D.C.: World Bank \& Oxford University Press.

World Bank. (2015). Mobile cellular subscriptions (per 100 people). Retrieved 13 March 2016, from http://data.worldbank.org/indicator/IT.CEL.SETS.P2

World Bank. (2016). World Development Report 2016: Digital Dividends. NewYork, USA: The World Bank.

Yusra, S. (2011). Assessing the motivation to submit VGI: Case study of a human sensor web in Zanzibar. (MSc thesis), University of Twente, Enschede, Netherlands. 
Chapter 2

Concepts and overall approach 


\subsection{Introduction}

In this section, I present key concepts that helped to frame the analysis and answer the sub-research questions. These concepts include access to water, exit and voice, formal and informal organizational structures, and discretion and transaction-intensiveness of public service tasks. Table 2.1 presents the connection between the research sub-questions and the key concepts for each.

Table 2.1: Connection between Concepts and Research Questions

\begin{tabular}{|ll|l|}
\hline \multicolumn{1}{|c|}{ Research question } & \multicolumn{1}{|c|}{ Concepts } \\
\hline 1. & $\begin{array}{l}\text { What do official statistics on access to urban water } \\
\text { services reveal and/or conceal? }\end{array}$ & $\begin{array}{l}\text { Measures of access to } \\
\text { water }\end{array}$ \\
\hline 2. & $\begin{array}{l}\text { Which strategies do citizens use to protest } \\
\text { substandard water services and to what effect? }\end{array}$ & Exit and voice \\
\hline 3. & $\begin{array}{l}\text { Does awareness of how rural water supply is } \\
\text { organized empower rural citizens to demand better } \\
\text { services? If not, what does? }\end{array}$ & $\begin{array}{l}\text { Formal and informal } \\
\text { organizational } \\
\text { structures }\end{array}$ \\
\hline 4. & $\begin{array}{l}\text { How can ICTs play a role in the monitoring by } \\
\text { citizens of water services? }\end{array}$ & $\begin{array}{l}\text { Discretion and } \\
\text { transaction- } \\
\text { intensiveness }\end{array}$ \\
\hline
\end{tabular}

Finally, I highlight my overall approach to this study, which is "working with the grain" of citizen-provider relations and against the hype of the dominant discourse that looks at information technology, empowerment, voice, accountability and public service performance as magic variables linked in a mutually beneficial way - "all good things go together." As I moved from one empirical setting to the next, I gained knowledge through reflexivity-the capacity to be caught by surprise when my findings did not yield expected results, and to reflect upon and revise my initial categories and assumptions.

\subsection{Measures of access to water}

Consensus regarding the definition of access to water and the way it is measured is an important factor in understanding the opportunities for citizens to improve water services. Matching up official definitions with citizens' perceptions of access to water can reveal two things. First, it can determine whether the official understanding of access to water is relevant to citizens, and second, it enhances planning for the operation and maintenance of water schemes (Kristof, 2005). More importantly, a mismatch between the official definitions of access and those of citizens may help in monitoring the efficacy of interventions in improving access to water for citizens. This section covers concepts for defining access to water and its measures.

Stakeholders in the water sector, particularly donors, governments and researchers, disagree on the appropriate definition of access to water. The most frequently used definitions compare water access within and between 
countries in order to quantify the global status and progress towards achievement of the Millennium Development Goals (MDGs). The MDG goal 7 aimed to "halve, by 2015, the proportion of the population without sustainable access to safe drinking water and basic sanitation". To monitor progress with this goal, the WHO/UNICEF Joint Monitoring Programme (JMP) defines access to safe drinking-water as the "proportion of population using an improved drinking-water source" (UNICEF/WHO, 2012). Critics contend that the JMP definition does not capture the complex nature of water, particularly from the perspective of the users. For Kristof (2005), good access to water implies access to "a reliable source of water which supplies adequate quantity and adequate quality of water in a convenient way" (Kristof, 2005, p. 3). Others substitute access to water with "water use" arguing that mere provision of water does not necessarily indicate actual use by the people (Kayaga et al., 2009). Kudat et al. (1993) argue that households are more likely to demand certain attributes of water and not water itself. They observe that different attributes of water have different value depending on the intended use by the households. For instance, the quality of water may be very important for uses such as drinking and cooking as opposed to water for watering plants.

It is only recently that a formal definition of water is emerging that includes issues such as reliability, affordability, equity, and safety. Target 6.1 of the SDGs aims to achieve "universal and equitable access to safe and affordable drinking water for all by 2030" (WHO-UNICEF, 2015) and thus introduces the new dimensions of universality, equity, safety, and affordability ${ }^{7}$. Given that these measures are still designed to monitor access to water globally, critics argue that they are less suitable for local realities and further exemplify the challenge in data collection. Likewise, the new targets are likely to face similar challenges highlighted by O'Hara et al. (2008), who argued that the base data upon which the targets are set and against which progress will be measured are problematic.

Perceptions of citizens regarding access to safe drinking water form a foundation for citizens to monitor the quality of the services they receive from a provider. Hirschman's concepts "exit and voice" provide an analytical tool for understanding how citizens are likely to respond when faced with the deterioration of a service provider (Couldry, 2010; Dowding \& John, 2012; Dowding et al., 2012; Hirschman, 1970; Schedler, 2002).

\subsection{Exit and voice}

In his seminal treatise, Exit, Voice and Loyalty, Hirschman (1970) suggested that members or customers of an organization, whether a business, a nation

7 These dimensions are further discussed in Chapters 4 and 5. 
or any form of human grouping, have two possible responses when they perceive that the organization they depend on is deteriorating in quality: they can either withdraw from the relationship with the organization (exit), or, attempt to improve the relationship through communication of the complaint, grievance or proposal for change (voice).

Young (1974) argued that voice is more efficient than exit when (i) the service provider is a monopoly making exit costly, (ii) the public services cannot be differentiated (both poor and affluent customers get the same water from the piped scheme) and those with weak voice gain from the vocal few, and (iii) the service is ill-defined and therefore difficult to evaluate. Inhibitors to voice are: (i) informational asymmetries, e.g. when service providers possess information not available to the public, (ii) the government's ability to restrict the public's access to information, (iii) legal and institutional barriers e.g. some user groups are not recognized and are denied the right to sue public service providers, and last but not least, (iv) social barriers (lack of income and education) limiting the ability to use voice (Paul, 1991, 1992).

Exercising voice has dividends for voicers. Voice is an information rich form of preference expression, a rewarding activity in its own right and scalable from domain to domain. A citizen's acquired skill to exercise voice to complain for water services can be applied to other services as well. An important aspect of Hirschman's argument is that customers combine exit and voice in their effort to improve organizational performance, because exit and voice are not mutually exclusive (Barry, 1974). Last but not least, exit and voice combinations are multiple and can vary in intensity and form (Keeley \& Graham, 1991).

\subsection{Formal and informal organizational structures}

Informality is ubiquitous in the workings of African bureaucracies (Booth, 2012; Holzer, 2014) and in the interactions between citizens and service providers as my personal narrative amply shows.

To conceptualise formality and informality in rural water supply, I use the systems approach to organisations (Kühl, 2013). The systems' approach suggests that any organisation, however complex, has three types of structures-programs, communication channels and members. Structures are premises upon which decisions are routinely made within an organization. The premises are either formally decided (thus giving rise to formal structures) or informally "decided" (thus giving rise to informal structures). Programs determine which actions in the organization are to be viewed as right, and which as wrong. Communication channels define how information must be communicated within the organization and the pathways it must follow. For 
members, the underlying consideration is that the type of individual placed in a given position will make a difference for future decisions within the organisation.

Programs constitute the first structure. In rural water supply, formal programs include legislative acts, policies, and information systems (e.g. the Water Point Mapping System of the Ministry of Water in Tanzania). They determine which formal responsibilities organisational members have and, consequently, which of their actions are to be viewed as right or wrong, and rewarded or sanctioned, respectively. The 2002 National Water Policy (United Republic of Tanzania, 2002b) and related legislative acts (United Republic of Tanzania, 1982, 1998a, 2009) determine the responsibilities of local councillors, COWSOs and district officials in rural water supply. For instance, councillors must access district public records and raise questions in water-related council meetings. COWSOs must follow up on non-functional water points and mobilize communities for their revival. District officials must provide information on the status of water services in the district. Informal programs may take the form of wellestablished, customary routines and dictate informal responsibilities such as citizens expecting councillors to contribute their own funds for water projects.

Communication channels are the second structure within the rural water sector. Formal communication channels include the rules and procedures and information flows among organisational members. Communication channels are the only means of preventing communications overkill (everybody communicating with everybody else) within an organization. For instance, chapter 7 describes in minute detail the formal and informal rules and procedures governing the information flow between a village COWSO and the district council when a rural water point breaks down. Informal communication channels develop when formal hierarchies are routinely bypassed, or when informal hierarchies are set up based on political party or tribal affiliations. Examples are COWSO leaders bypassing the village assembly, and instead reporting their performance to leaders of civic associations during village feasts or citizens contacting political figures or central government public officials (not necessarily involved in the water sector) to force district officials to respond to their needs.

Members constitute a third structure, because decisions that affect the organization always depend on who occupies the position responsible for making them (Kühl, 2013). A COWSO or village leader who belongs to the ruling political party may decide differently on rural water supply from a leader who leans towards the opposition. In the late 1960s, when Julius Nyerere massively resettled peasants to newly formed villages, peasants often chose petty-capitalist farmers as village leaders "on the assumption that they were better equipped to deal with officials, including protecting them from 
government interventions that would threaten their livelihood. In places where there were no such petty-capitalists, villagers often chose individuals known not to be interested in change" (Hydén, 1980, p. 114), emphasis in original), but people whose interest in interfering with the villagers' life was small. Informal members in rural water supply are institutions outside the formal rural water hierarchy and include the Church, Islamic institutions, or grassroots civic associations.

Informality may be either compatible with formality, or it may break the formal rules and procedures (but still be useful) or it may break the law. Informality cannot be suppressed by decree; it can take different, perhaps more desirable forms only when changes are made to the formal structures themselves. For instance, in September 2015, the Ministry of Water and Irrigation introduced a new program to revamp the updating mechanism of the Water Point Mapping System and created new roles and responsibilities for Ministry officials (United Republic of Tanzania, 2015a). This change of formal rules and procedures will not supress informality. Instead, it may lead to new informal structures that are more conducive to improvement of rural water services at the district and village levels.

\subsection{Discretion and transaction-intensiveness}

In order to decide which elements, if any, of the information flow between citizens and government can be digitized, I draw on (Pritchett \& Woolcock, 2004; World Bank, 2014), who distinguish between discretionary and transaction-intensive elements in key services ${ }^{8}$ to citizens, and adapt the concepts to micro-level tasks of decision making. Transaction-intensive tasks require a large number of transactions, involving face-to-face contacts between district officials, village water technicians, Community Owned Water Supply Organization (COWSO) members, and citizens, for example a water technician detecting a broken water point and reporting to the cowsO secretary. Discretionary tasks involve decisions based on information that "is important but inherently imperfectly specified and incomplete, and entails extensive professional or informal context-specific knowledge" (Pritchett \& Woolcock, 2004, p. 194). A village assembly agreeing to contribute funds for water point repair or a district official approving a COWSO's request for funds are discretionary tasks.

Transaction-intensive tasks are easily amenable to digitization while discretionary tasks are not because the actor's decisions cannot be mechanized. Non-discretionary and transaction-intensive tasks can easily be

\footnotetext{
${ }^{8}$ Key services are those for which some government action is necessary, desirable, and/or inevitable, e.g. improved water supply, sanitation, and health.
} 
codified in computer programs (World Bank, 2016). Tasks that are neither discretionary nor transaction-intensive are lasting dispositions, "propensities to think, feel, and act in determinate ways, which then guide [people] in their creative responses to the constraints and solicitations of their extant milieu" (Wacquant, 2005, p. 316), but digitization does not apply to them. They include the systematic preference of villagers to meetings for distribution of food for hunger relief and to attending funerals rather than COWSO meetings, but also more general patterns of mutuality and reciprocity that pervade village social life and underpin the "economy of affection" in rural Tanzania (Hydén, 1980).

\subsection{Working with the grain approach}

Working with the grain forms my main guidance in understanding interactions between citizens and water providers prior to introducing any changes, including ICT and mobile phone platforms, in the water sector. The approach offers an alternative to development "blueprints" that have frequently failed to produce successful and sustainable results in many developing countries. For many decades, the Global South has been receiving development blueprints from the Global North, with the hope that these "best practices" would solve developmental problems in the South. However, the blueprint approach has failed to produce the intended results particularly in governance-related interventions. This has resulted into an emerging school of thought that argues for working with the grain. Rather than adopting Western ways of doing things wholesale, the idea is to instead combine certain elements of the Western experience with indigenous strengths and create distinctive new models of development (Kelsall, 2011). The approach appeals to the notion of incrementalism, allowing a stepwise form of development that enables directing attention to regularly learning lessons and sustaining forward development (Levy, 2014b).

"Working with the grain" in development interventions (Booth, 2012; Kelsall, 2011; Srivastava \& Larizza, 2013) starts with the way things are on the ground, seeks incremental ways of achieving modest gains (Levy, 2014b) and does not harm the institutional fabric of a country by bypassing local institutions. In this study, "working with the grain" also stands for incrementalism and digitization efforts that can be reversed, redesigned and redeployed until there is a sustainable fit with the empirical setting.

The basic idea is not new. James C. Scott in a speech on his famous book "Seeing like a State", gives an example of how Japanese engineers "work with the grain" in water management. If they want to redesign a stream or small river, 
"they will live along that river for a year or two just studying the water movement and different rain patterns at different times of the year and after two years or so they will make a small intervention, a little check dam, and then they'll watch for another month or two what the water does around that check dam and in different circumstances, after heavy rainfall, in a drought. So each of their interventions is [...] reversible" (Scott, 2008, p. 10).

In his inaugural contribution to the Africa Power and Politics Program (APPP), Kelsall (2008) asked "what might African development with the grain look like?" He argued that informal African institutions in which mutual accountability is strong can provide clues as to the shape of development with the grain. These institutions include the extended African family and ethnic groupings (tribes) which place a high value on celebrating basic life-cycle rituals, such as births, initiations, marriages, and deaths, mutual financial help and the resolution of conflicts within the extended family or tribe and not by appealing to formal state agencies. Other effective institutions are churches and mosques which enjoy so much popular support that they are often financially self-sustaining. They are heavily involved in providing local education, water, and health, services, whose quality surpasses those provided by the state. In sum,

"many Africans do not first and foremost think of themselves as individuals; they think of themselves as members of limited extended families (extended families that may extend before birth and after death). Beyond that they identify, in concentric circles of weakening moral obligation, with wider extended families, clans, ethnic groups, and only then, if at all, with the nation state." ( $p .18$, emphasis added). 


\section{References}

Barry, B. (1974). Review Article: 'Exit, Voice, and Loyalty'. British Journal of Political Science, 4, 79-107. doi: doi:10.1017/S0007123400009376

Booth, D. (2012). Working with the Grain and Swimming against the Tide. Public Management Review, 14(2), 163-180. doi: 10.1080/14719037.2012.657959

Couldry, N. (2010). Why Voice Matters? Culture and Politics After Neoliberalism. London UK: SAGE Publications.

Dowding, K., \& John, P. (2012). Exits, Voices and Social Investment: Citizens' Reaction to Public Services Retrieved from http://itc.eblib.com/patron/FullRecord.aspx?p $=880673$

Dowding, K., John, P., Mergoupis, T., \& Van Vugt, M. (2012). Exit, voice and loyalty: Analytic and empirical developments. European Journal of Political Research, 37(4), 469-495. doi: 10.1023/A:1007134730724

Hirschman, A. O. (1970). Exit, Voice and Loyalty: Responses to Decline in Firms, Organizations and States. Cambridge, MA: Harvard University Press.

Holzer, B. (2014). The two faces of world society. In B. Holzer \& T. Werron (Eds.), From Globalization to World Society: Neo-Institutional and Systems-Theoretical Perspectives. London/New York: Routledge.

Hydén, G. (1980). Beyond Ujamaa in Tanzania: underdevelopment and an uncaptured peasantry, London. Berkerly and Los Angels: University of California Press.

Kayaga, S., Fisher, J., \& Franceys, R. (2009). Improved access to urban water services in Uganda. Proceedings of the Institution of Civil Engineers: Municipal Engineer, 162(3), 165-170.

Keeley, M., \& Graham, J. W. (1991). Exit, voice, and ethics. Journal of Business Ethics, 10(5), 349-355. doi: 10.1007/bf00383236

Kelsall, T. (2008). Going with the grain in African development? The APPP Discussion Paper No. 1. London, UK: Africa Power and Politics Programme (APPP), Overseas Development Institute.

Kelsall, T. (2011). Going with the Grain in African Development? Development Policy Review, 29, s223-s251. doi: 10.1111/j.1467-7679.2011.00527.x

Kristof, B. (2005). Monitoring of Water Supply Coverage. WELL fact sheet. Retrieved 25/07, 2013, from http://www.lboro.ac.uk/well/resources/factsheets/fact-sheets-htm/mwsc.htm

Kudat, A., Bell, M. E., Boland, J. J., Humplick, F., Madanat, S., \& Mukherjee, N. I. (1993). Reliability of Water Supply in Developing Countries: The Emperor Has No Clothes. Washington, DC: The World Bank.

Kühl, S. (2013). Organizations: A Systems Approach (P. Schmitz, Trans.): Routledge.

Levy, B. (2014b). Working with the Grain: Integrating Governance and Growth in Development Strategies. New York: Oxford University Press. 
O'Hara, S., Hannan, T., \& Genina, M. (2008). Assessing access to safe water and monitoring progress on MDG7 target 10 (access to safe water and basic sanitation): Lessons from Kazakhstan. Water Policy, 10(1), 1.

Paul, S. (1991). Accountability in public services: Exit, Voice and Capture WPS 614. Washington, DC: The World Bank.

Paul, S. (1992). Accountability in public services: Exit, voice and control. World Development, 20(7), 1047-1060. doi: http://dx.doi.org/10.1016/0305$750 \times(92) 90130-\mathrm{N}$

Pritchett, L., \& Woolcock, M. (2004). Solutions When the Solution is the Problem: Arraying the Disarray in Development. World Development, 32(2), 191-212. doi: 10.1016/j.worlddev.2003.08.009

Schedler, A. (2002). My Vote? Not for Sale: How Mexican Citizens View Electoral Clientelism. Paper presented at the The Comparative Politics of Vote Buying, Cambridge, Massachusetts.

Scott, J. C. (2008). Professor James Scott's Lecture Transcript. Glasgow: Glasgow Centre for Population Health, University of Glasgow.

Srivastava, V., \& Larizza, M. (2013). Working with the grain for reforming the public service: A live example from Sierra Leone. International Review of Administrative Sciences, 79(3), 458-485. doi: $10.1177 / 0020852313491513$

UNICEF/WHO. (2012). Progress on drinking water and sanitation: 2012 Update. New York: WHO/UNICEF Joint Monitoring Programme for Water Supply and Sanitation.

United Republic of Tanzania. (1982). The Local Government (District Authorities) Act, 1982. Dar es Salaam, Tanzania: United Republic of Tanzania.

United Republic of Tanzania. (1998a). Local Government Reform Programme Policy Paper on Local Government Reform. Dar es Salaam, Tanzania: Ministry of Regional Administration and Local Government.

United Republic of Tanzania. (2002b). National Water Policy 2002. Dar es Salaam, Tanzania.

United Republic of Tanzania. (2009). Tanzania Water Supply and Sanitation Act (2009). Dar es Salaam, Tanzania: United Republic of Tanzania.

United Republic of Tanzania. (2015a). Processes \& Procedures for Updating Rural Water Point Data in Tanzania: User Manual. Dar es Salaam, Tanzania: Ministry of Water, Rural Water Supply Division (RWSD).

Wacquant, L. (2005). Habitus. In J. Becket \& Z. Milan (Eds.), International Encyclopedia of Economic Sociology (pp. 315-321). London: Routledge.

WHO-UNICEF. (2015). Methodological note: Proposed indicator framework for monitoring SDG targets on drinking water, sanitation, hygiene and wastewater.

World Bank. (2014). World development report 2015: Mind and Society, Behavior. Retrieved 19 October, 2014, from http://go.worldbank.org/HYR6FHEK60 
World Bank. (2016). World Development Report 2016: Digital Dividends. NewYork, USA: The World Bank.

Young, D. R. (1974). Exit and voice in the organization of public services. Social Science Information, 13(3), 49-65. doi: 10.1177/053901847401300303 
Chapter 3

Methodology 


\subsection{Research approach}

I employ a qualitative research approach and a descriptive and exploratory research strategy. The flexibility offered by a qualitative research approach (Yin, 2011) fits well the main research question where I empirically enquire about the factors affecting citizens' strategies to improve access to water services and how.

Since the objective of this research requires a rich understanding of the various strategies used by citizens to improve access to water in urban and rural areas, a multiple case study design seemed highly appropriate. The flexibility offered by a qualitative research approach (Yin, 2011) fits well the research objective. When the researcher cannot manipulate the relevant behaviour and contemporary events are examined within a social context, a case study is the preferred research design (Yin, 2009). Because the context is deliberately part of the design, there will always be too many 'variables' for the number of observations made: consequently the application of standard experimental and survey designs and criteria are not appropriate, although issues of validity and generalizability have to be addressed. Yin (2009) states that though a multiple case design is complex, it permits induction of rich and reliable portrayals of the social world. I have been guided by interpretive philosophical assumptions. My aim was to create a contextual understanding of citizens' strategies by interpreting the meanings of informants and their shared assumptions towards access to water within the formal and informal structures of the water supply sector.

\subsection{Moving across empirical settings}

My first case was water supply in the city of Dar es Salaam, a selection both purposive and spontaneous. It should be noted that when I began this study, and partly due to the exploratory strategy of the research, there were many uncertainties on where to start. This was also due to the fact that this study was part of a larger research project designed to cover health and water services. Having these broad sectors meant that there were too many options to choose from and at the same time coordinate with the other PhD students. Following discussions with senior and junior members of the SEMA team, we finally decided to start fieldwork in Dar es Salaam, because of the richness in data sources and the presence of major stakeholders in the water sector, including NGOs, the Ministry of Water and DAWASCO, the largest water utility in the country.

After studying water supply in the setting of a large city, it was clear that the next case should involve water supply in a smaller town and rural areas. This was another collective call and relevant to my multiple case study design. As a research project, SEMA partnered with SNV, a Netherlands Development 
Organisation based in Tanzania, for sharing experiences. SNV has extensive experience in collaborating with local organizations, especially for strengthening accountability relationships between local governments, citizens and councillors with the aim of improving water service delivery in rural areas. In addition, SNV was at the forefront, with WaterAid and Ingeniería para el Desarrollo Humano (ONGAWA), of water point mapping (WPM) in Tanzania. SNV played a major role in facilitating entry to Mashujaa-fictitious namedistrict council. Mashujaa is one of many districts that have benefited from SNV's work. Mashujaa provided both urban and rural water supply settings thereby allowing me to explore i) how citizens (as consumers) in a small town protest service failures and interact with frontline and back-stage officials of small town water utilities, and ii) how citizens (as co-producers and monitors) in four villages of one of the poorest districts in Tanzania communicate, interact and work together with the district council in reporting and fixing water breakdowns.

Rural water supply in Hai and Siha districts in Kilimanjaro region is the last case for this research. I became aware of the successful water supply in the two districts during a presentation in Dar es Salaam of preliminary findings from Mashujaa district. Julie Adkins of SNV, one of the top governance experts in the water sector, suggested that it would be a good idea to confront my findings from Mashujaa (which portrayed a dismal state of water services) with well-performing community-managed rural water projects in Hai and Siha districts. My own desk research confirmed that Hai and Siha districts would make an invaluable addition to the research. These water projects highlight various elements of sustainability in rural water supply. The communitymanaged water projects in Hai and Siha districts appeared to be functioning reasonably well and sustainably (Mayo \& Nkiwane, 2013). Citizens in rural Hai and Siha districts have 24/7 access to clean tap water from communitymanaged water projects. These features became a good motivation for including Hai and Siha districts as a case study. Specifically, the two districts provided a good contrast to the state of water services presented in the other cases.

\subsection{Data collection methods}

\subsubsection{In-depth interviews}

I conducted semi-structured interviews with citizens, water utility officials, politicians and government officials to ascertain their views on the current state of access to water within their jurisdiction. Semi-structured interviews were also conducted with street chairpersons and street executive officers to document their perspectives regarding access to water. I also interviewed NGO staff to understand their interactions with citizens particularly in Dar es Salaam. 
As shown in my own experiences in accessing water services (see section 1.2), it is somewhat difficult to draw the boundary of the sources of information for this research. I interacted with water utility officials, neighbours, fellow water users/clients, private water providers. These interactions took place both in private and public venues - water utility and ministerial offices, homes, streets as well as in buses, drinking joints and eating-places. Finally, personal encounters with family members and relatives, colleagues, friends and sometimes with strangers have been useful for understanding the experiences and coping strategies of Tanzanian citizens (both in urban and rural areas) in accessing water services. Their contribution has also somehow influenced my conversations during interviews. I conducted almost all interviews in Kiswahili, transcribed these and the field notes, translated into English.

\subsubsection{Focus group discussions}

I conducted eight focus group discussions in the four villages in Mashujaa district, during March 2016. The aim was to acquire a deeper understanding of citizens' perceptions of their responsibilities and those of Community Owned Water Supply Organizations (COWSOs), councillors and district officials. The Village Executive Officer (VEO), accompanied by me, selected and invited citizens by mobile phone or home visits in each village. We reimbursed the VEOs for the calls they made. We recruited eight groups (two groups in each village) of ten people for meetings of about two hours. All invitees showed up and were separated in two groups, the young and the old. Their ages ranged from 19 to 60 years. Most came to the venue by walking. Those who came by motorbikes were reimbursed for the cost of transport. Each group featured both genders and a mix of peasants, livestock keepers, petty traders, and retirees (e.g., retired soldiers and teachers).

\subsubsection{Direct observation}

This research benefited from information collected through countless interactions with citizens, government officials and water technicians. My fieldwork was considerably long usually not less than six months, except in Hai and Siha districts, where I had to cut short my fieldwork due to typhoid sickness. These long stays in the research areas made me a familiar and trusted figure in the city, town or villages. I was able to have numerous formal and informal interactions with district officials, COWSO leaders, village leaders, politicians and common citizens. I was allowed to accompany district officials handing over COWSO certificates in nineteen villages. This helped me to create relationships with focus group participants and to raise pertinent discussion points during the sessions. Participant observation led to a better appreciation of the experiences and challenges of the water users as well as government and utility officials. Informal interactions with informants in the market, in 
canteens and on the street revealed socio-cultural aspects that interviews alone cannot capture (Iacono et al., 2009).

Workshops organized by the SEMA project (see the next section) provided another important platform for direct observation. During the second workshop, in particular, I observed how water committee members, politicians and district officials on how they react to the SEMA app. In this case, the SEMA app was an USSD ${ }^{9}$ application aimed at reporting the status of rural water supply. Observational aspects included i) confusion or excitement of the reporters, ii) difficulty/easiness in using the app, and iii) aspects of the app attracting attention of the reporters. This information was very useful when conducting a follow up research as well as answering the fourth research question that seek to understand how ICTs play a role in the monitoring of water services by citizens.

\subsubsection{Workshops}

This research has significantly benefited from knowledge and empirical data from three workshops that were organized by SEMA. The first workshop was conducted in Dar es Salaam on $7^{\text {th }}$ and $8^{\text {th }}$ May 2012. The workshop brought together junior and senior researchers within SEMA and other key stakeholders including representatives from the Ministry of Water, University of Dar es Salaam and the World Bank. The workshop had two main objectives, i) bring together SEMA team members to meet for the first time to discuss research concepts, and, ii) identify criteria for selecting case study areas and discuss the working approach and collaboration models. Key stakeholders who commented on the research and fieldwork plans also joined us. The workshop also initiated collaboration with partner organizations working in the water sector such as the World Bank and the Ministry of Water.

The second workshop titled as "Sensors, Empowerment, and Accountability (SEMA): (Dis)connecting people and water" was conducted at the Faculty of Faculty of Geo-Information Science and Earth Observation (ITC) of the University of Twente, on $10^{\text {th }}$ and $11^{\text {th }}$ September 2013 . This workshop reinforced contentions regarding the use of mobile phones to mediate access to water, particularly given the informality and involvement of the private sector in the provision of water services. For me, the workshop was an inspiration to continue seeking to understand how mobile phones could facilitate reporting problems and consequently enhance water point repairs. This became part of the motivation for answering a research question presented in Chapter 7.

\footnotetext{
9 Unstructured Supplementary Service Data (USSD) is a communication protocol used between mobile phones and service providers (www.wikipedia.com).
} 
The third workshop was conducted in the last week of February 2015 at Mashujaa's district council. It brought together the SEMA research team, councillors, district officials and COWSO leaders from four selected villages. The purpose was to present the SEMA mobile phone-based platform to the participants and receive their feedback on its usefulness. We asked the participants which type of information was useful to them for fulfilling their responsibilities and who they considered as appropriate providers of information on the functionality of water points at the village level.

Table 3.1 summarizes the case studies' location (large-city, small town, village), approximate population size and type and numbers of respondents.

Table 3.1: Overview of case studies

\begin{tabular}{clllc}
\hline S/N & Case study & Urban/rural & Type of respondents & $\begin{array}{c}\text { Number of } \\
\text { respondents }\end{array}$ \\
\hline 1 & Dar es & Large city & Citizens & 22 \\
& Salaam & & District water officials & 2 \\
& (Kinondoni & & Street water vendors & 6 \\
& and Temeke & & Street chairpersons & 4 \\
& districts) & & NGO staff (BTC and & 2 \\
\hline 2 & Mashujaa & Small town & Catizens (interviews) & 12 \\
& town & & Citizens (audio recordings) & 11 \\
& & Water utility officials & 7 \\
& & Water vendors & 3 \\
& & Councillors & 2 \\
\hline 3 & Mashujaa & villages & Citizens (interviews) & 23 \\
& rural & & Citizens (focus groups) & 80 \\
& & COWSO leaders & 8 \\
& & Water technicians & 4 \\
& & Security guards & 3 \\
& & & Pump attendants & 6 \\
& & & Village leaders & 12 \\
& & & Councillors & 2 \\
\hline 4 & Hai and Siha & Small towns & Citizens & 11 \\
& districts & and villages & Water trust staff & 6 \\
& & Water committee members & 8 \\
& & & Water agents & 3 \\
& & & Water Service Facility staff & 2 \\
& & & District Water officials & 2 \\
\hline
\end{tabular}

\subsection{Research ethics}

While I committed myself to abide to the highest standard of professional ethical norms and values, it is important to note some of the ethical approaches I employed in carrying this research. Specifically, I followed four main research ethical principles: i) protecting the anonymity and confidentiality of informants, ii) minimising the risk of harm to them, iii) obtaining informed consent, and iv) providing participants the right to withdraw from an interview, if they felt uncomfortable. 
In order to minimize the risks of harm to my research participants, I took care to not disclose participants' identities and I use a fictitious name for the geographical location of Mashujaa district. I explicitly promised all informants in Mashujaa district to fully anonymize the villages and the district to protect them from inconvenience resulting from the information they shared, especially because fieldwork took place before the presidential election in October 2015 and the fear, especially of government employees, of being fired was palpable.

Research participants for this study were aware that they were taking part in the study and volunteered to take part, without coercion. I made sure that they understood what the research required of them by highlighting and clarifying the purpose of the research, the methods, the possible outcomes, as well as associated demands, inconveniences and risks that the participants could face. However, there is one notable instance where it was not possible to obtain informed consent from research participants. In Chapter 5, I used secondary data ("secretly recorded" data by water authorities) for which customers had not given consent. I pondered the ethics of doing this. However, I consider that the benefits of using the data outweigh the lack of informed consent. I am aware of the ethical implications of accessing non-consented data (ESRC, 2015) and the need for alternatives when dealing with issues involving the role of the government (Spicker, 2007). First, accepting to listen to the audios allowed me to gain confidence from the water authorities as they were expressing the challenges they faced, such as customers avoiding payments and other irregularities. Second, by analysing the recordings I exposed customers' frustrations and the water utility-customer relationships.

Lastly, I explicitly informed participants that they had the right to withdraw at any time of the interviews or focus group discussions. Fortunately, none of my research participants withdrew.

\subsection{Reading guide}

My thesis consists of three main parts. The first part comprises Chapters 1, 2 and 3 . The first chapter presents the background to my thesis and contextual information about the state of water access in Sub-Saharan Africa and Tanzania. My personal narrative of access to water in Tanzania introduces the reader to the daily struggles and coping strategies of citizens in urban and rural areas and presages the findings of my empirical research. Chapter 2 describes the research motivation and research questions, while Chapter 3 discusses the data collection and research methods.

The second part comprises Chapters 4, 5, 6, 7 and 8, the empirical part of my research. Chapter 4 describes poor and affluent citizens' strategies for 
accessing water in urban areas, particularly in Dar es Salaam. It shows how official statistics do not count and reveal what counts for citizens. The next chapter explores face-to-face protest strategies of citizens who are water customers in a small town in one of the poorest Tanzanian districts. It reveals the mismatch between customers' protest strategies and existing formal/informal complaint mechanisms of the water utility. Chapter 6 takes a closer look at how representatives of Community Owned Water Supply Organizations (COWSOs) communicate via (in)formal channels, interact and work together with district level frontline providers and managers of the water authority in reporting and fixing breakdowns in rural areas. Chapter 7 describes the information flows associated with the detection and repair of broken water points in four villages and shows how ICTs could play a role in the monitoring and repairing of water points. Chapter 8 is the epilogue of the second part of my thesis. It provides a contrasting case study of successful rural water supply led by a church organization and underpinned by the tribal ethos of the dominant tribe in the area.

Finally, Chapter 9, the third part of my thesis, concludes my study on the factors affecting citizens' strategies in improving access to water. Chapter 9 also highlights future directions and implications for practice. 


\section{References}

Berger, P. L., \& Kellner, H. (1981). Sociology Reinterpreted: An Essay on Method and Vocation: Penguin Books.

ESRC. (2015). ESRC Framework for research ethics Updated January 2015. Swindon, UK: The Economic and Social Research Council (ESRC).

Iacono, J., Brown, A., \& Holtham, C. (2009). Research Methods - A Case Example of Participant Observation. The Electronic Journal of Business Research Methods, 7(1), 39-46.

Mayo, A. W., \& Nkiwane, L. (2013). The role of community participation on cost recovery and sustainability of rural water supply projects in Hai District, Tanzania. Journal of Environmental Science and Water Resources, 2(11), 388 - 395.

Spicker, P. (2007). Research without consent. Social Research Update, Winter 2007(51).

Yin, R. K. (1981). The case study crisis: some answers. Administrative Science Quarterly, 26, 58-65.

Yin, R. K. (2009). Case study research: Design and methods (4th ed.). Thousand Oaks, CA: Sage.

Yin, R. K. (2011). Qualitative Research From Start to Finish. New York, U.S.A: The Guilford Press. 


\section{Chapter 4}

\section{Accessing water services in Dar es Salaam: are we counting what counts? ${ }^{10}$}

10 This chapter is based on Nganyanyuka, K., Martinez, J., Wesselink, A., Lungo, J., Georgiadou, Y. (2014). Accessing water services in Dar es Salaam: Are we counting what $\begin{array}{lcc}\text { counts? } & \text { Habitat } & \text { International, } \\ \text { http://dx.doi.org/10.1016/j.habitatint.2014.07.003 }\end{array}$ 


\begin{abstract}
A significant proportion of urban residents in developing countries has no access to public water supply and relies on unofficial, or even illegal, sources. They buy water from small scale water vendors or collect it from unimproved water sources. This paper draws on qualitative semi-structured interviews with public officials, private water providers and citizens to document details of citizens' strategies for accessing water in Dar es Salaam, Tanzania. From these data, we develop a descriptive and evaluative framework to capture the complex mix of sources, uses, and intermediaries in planned and unplanned settings and by affluent and poor citizens. We assess to what extent these strategies solve access problems like quantity, quality, affordability and reliability. We conclude that statistics such as the Millennium Development Goals do not count the access to drinking water that counts for citizens. We discern a bias towards formal state or privatised city-wide systems, discounting the mostly informal, small-scale and unofficial strategies to access water.
\end{abstract}

Key words: Access to water; informal water providers; Millennium Development Goals; Dar es Salaam

\title{
4.1 Introduction
}

In many developing countries, citizens' access to reliable and safe water remains a challenge. Current trends show more pronounced deficiencies in sub-Saharan Africa. In 2010 , only $61 \%$ of the population in sub-Saharan Africa had access to improved water sources (UNICEF/WHO, 2012). When issues of water quality and quantity are considered, the reality is more disheartening (Satterthwaite, 2003, p. 184). Using household surveys, Zérah (2000) finds disparities between access to water as stated by official statistics and the actual water supply situation from a user's point of view. The above raises issues of what is being counted (how access is defined) and how it is being counted (are data accurate). In this paper we focus on the former with a detailed study of citizens' access strategies in Dar es Salaam, Tanzania. We develop a descriptive and evaluative framework to capture the complex mix of sources, uses, and intermediaries in planned and unplanned settings and by affluent and poor citizens. We assess to what extent these strategies solve multiple access problems like quantity, quality, affordability and reliability, and add a few dimensions of access that emerge from our study. One-size-fits-all solutions are likely to fail in diverse contexts and conditions (locality, economy, politics, institutions, living conditions, family and persons). Qualitative approaches have the ability to uncover realities that otherwise would be "little recognized" or "passed unseen" (Rasmus Heltberg, 2012). The qualitative approach employed in this study complements quantitative studies on how people cope with poor access to water. 
Stakeholders in the water sector, particularly donors, governments and researchers, disagree on the appropriate definition of access to water. The most frequently used definitions are aimed at comparing water access within and between countries in order to quantify the global status and progress of international interventions like the Millennium Development Goals (MDGs). The MDG goal 7 aims to "halve, by 2015, the proportion of the population without sustainable access to safe drinking water and basic sanitation". To monitor progress with this goal, the WHO/UNICEF Joint Monitoring Programme (JMP) defines access to safe drinking-water as the "proportion of population using an improved drinking-water source" (UNICEF/WHO, 2012). Critics contend that the JMP definition does not capture the complex nature of water particularly from the perspective of the users. For Kristof (2005), good access to water implies access to "a reliable source of water which supplies adequate quantity and adequate quality of water in a convenient way" (Kristof, 2005, p. 3). Others substitute access to water with "water use" arguing that mere provision of water does not necessarily indicate actual use by the people (Kayaga et al., 2009). Kudat et al. (1993) argue that households are more likely to demand certain attributes of water and not water itself. They observe that different attributes of water have different value depending on the intended use by the households. For instance, the quality of water may be very important for uses such as drinking and cooking as opposed to water for watering plants.

Yet other critics of the JMP definition argue with empirical data that using an improved drinking water-source does not necessarily mean access to safe drinking water (not contaminated) and falsify the assumption used by JMP (Gundry et al., 2006). Similarly, O'Hara et al. (2008) report that the deterioration of water sources lead to access to unsafe water even from pipes. Not counting adequately access to water may also benefit local governments by hiding the problem. Aggregate statistics hide the condition of the most marginalized and low-income communities (Cheng, 2013). Zawahri et al (2011) argue that a universal definition of improved access and a focus purely on quantifying infrastructure provision underestimate problems such as affordability of services and quality (Zawahri et al., 2011). From their research in the Middle East and North Africa, the authors observe that the diffusion of the MDG universal definition "has reinforced and magnified pre-existing incentives among domestic leaderships to hide their deficiencies" and "provided governments with perverse incentives, to prioritize reporting of aggregate coverage rates rather than investing in more adequate metrics to gauge quality, accessibility and affordability of services" (Zawahri et al., 2011, p. 1171).

The government of Tanzania adopts the MDG definition and reports accordingly that "the proportion of people served by the 19 urban water authorities using drinking water from improved sources increased from $74 \%$ in 2005 to $84 \%$ in 
December 2009" (United Republic of Tanzania, 2010, p. 48). Another definition used is the percentage of population with access to improved sources of water within $400 \mathrm{~m} / 30$ minutes (United republic of Tanzania, 2013c).

In Dar es Salaam, the official figures estimate that $51 \%$ of the population gets water directly from the official public water supplier (EWURA, 2012). However, Kjellén (2006) believes this figure to be one third, as most people purchase water from those with pipe connections or private boreholes, or fetch water from shallow open wells and buy bottled mineral drinking water. Affluent households may also construct their own well (Kjellén, 2006; Twaweza, 2008). The piped water service is extremely unreliable and characterized by extensive rationing and low pressures (Kjellén, 2006; Kyessi, 2005). Even when connected, citizens have to develop strategies, such as storing, while there is flow and/or reducing consumption, to cope with intermittent water supply. The poor are most affected by unreliable public water supply because they often live in informal settlements where piped water supply is absent by design.

\subsection{Describing strategies for accessing water}

Detailed studies into citizens' strategies for accessing water exist for other locations (Adeniji-Oloukoi et al., 2013; Hackenbroch \& Hossain, 2012; Nyarko et al., 2008; Pattanayak et al., 2005; Virjee \& Gaskin, 2010). Depending on the authors' theoretical focus, they describe just one or two aspects of access: affordability, cost recovery, consequences of poor access, water vendors and other intermediaries. Kristof's (2005) dimensions of reliability, convenience, adequate quantity and adequate quality are not detailed enough to evaluate access strategies (see Discussion below). Kjellén's PhD research on water supply in Dar es Salaam focusses on a project for privatisation of official water services, and presents affluent descriptions of water access and distribution in this city (Kjellén, 2006). However, none of these studies describes comprehensively or systematically citizens' strategies for access. Drawing on these studies and our own fieldwork, we propose the following descriptive parameters for access to water (Table 4.1): use, intermediaries, user, strategy. This detailed description allows us to evaluate how problems of access (also labelled dimensions of access) are solved. We focus on enhancement strategies and do not include accommodation. Enhancement refers to strategies to increase the level and quality of water supply services by supplementing the available supply. Accommodation strategies adjust behaviour to accommodate the unreliable supply of water, such as consuming less water by using it twice or using pit latrines rather than flush toilets even when the latter are available (Kudat et al., 1993, p. 3). 
Table 4.1: Parameters for access to water

\begin{tabular}{ll} 
Parameter & Description \\
\hline source & where is the water taken from? \\
use & what is the water used for? \\
intermediaries & who helps to get the water to the user? \\
user & who is using the water (income, planning status)? \\
strategy & is the strategy long or short term; individual or communal? \\
problems of access & what problem is solved by this strategy? \\
\hline
\end{tabular}

\subsection{Research design}

The study employed a qualitative research strategy as this offers researchers a tool for understanding the entirety of an experience. The flexibility offered by a qualitative research approach (Yin, 2011) fits well the research objective of investigating day-to-day experiences of citizens' strategies for access to water. Within Dar es Salaam, the study was conducted in the Kinondoni and Temeke municipalities. Within these, we selected four "streets" (the lowest administrative level), two in affluent areas (Masaki and Oyster Bay) and two in low income areas (Nyambwera and Mkunduge). Eventually, 22 citizens were interviewed, enough to reach saturation, a point where no more new stories and themes emerged (Guest et al., 2006). These in-depth interviews were conducted between November 2012 and May 2013. They addressed individuals' personal experiences on accessing water: type of water sources, time of collection, and interactions with water providers. Getting respondents in low income areas was easy given that many were at home during working hours. It was a challenge to find respondents in affluent areas since many people were not at home during working hours. Access to residents was only possible with a formal research permit from the street government office and the recruitment of a local guide. In some cases, two visits to a single house were required - first to make an appointment, followed by the actual interview on the second visit. Furthermore, semi-structured interviews were conducted with Kinondoni and Temeke Municipal Water Engineers to ascertain their views on the current state of access to water within their jurisdiction. Semi-structured interviews were also conducted with street leaders to document their perspectives regarding access to water. We interviewed NGO staff from WaterAid and the Belgian Technical Cooperation to understand their interactions with citizens in Mkunduge and Nyambwera. These organizations have assisted communities to improve access to water through community water projects. Views from officials allowed a comparison with the information collected from citizens. Snow-balling was used to locate water vendors in Mkunduge and Nyambwera streets; they were also interviewed. A review of published and unpublished documents from government, NGO and research institutions was also carried out, with emphasis on urban citizens' attitude toward access to water. This review helped to understand how organisations 
perceive and represent problems with water as well as the way they interact with citizens.

The data analysis process began in the field by summarizing the emerging themes observed during data collection as well as through informal discussions. Afterwards, audio recordings of the interviews were first transcribed into Swahili, the language used in the interviews. Swahili interview transcripts were then translated into English and imported into computer aided qualitative data analysis software. Field reports, field notes and secondary literature were also imported. In order to maintain the anonymity of respondents, all transcripts were given numbers e.g. OY1 = first respondent in Oyster Bay. Thematic coding (Bryman, 2012) was used to analyse the data where meaningful segments of text from the transcripts were assigned a code, for example "water prices" and "water quality".

\section{CASE STUDY AREAS}

Dar es Salaam is one of the fast growing cities in the Africa with a population of 4.4 million people (National Bureau of Statistics, 2013). A significant proportion of Dar es Salaam population has no adequate access to water supply. Likewise, a large proportion of Dar es Salaam population lives in unplanned settlements creating a challenge for them to access piped water. As a result, the majority of the population relies on public standpipes and informal providers as their main source of water.

Dar es Salaam Water and Sewerage Corporation (DAWASCO) is the official supplier of water and sewerage services in the city. DAWASCO has three major reservoirs, constructed in 1976, 1958 and 1947 respectively. Other sources include boreholes, which were constructed in 1997. In total, DAWASCO produces 245 million litres of water as compared to the estimated demand of 533 million litres (United Republic of Tanzania, 2013b). However, not every drop of the produced water reaches the users: the Ministry of Water estimates that $49 \%$ of the produced water is lost due to old infrastructure and illegal water connections (United Republic of Tanzania, 2013b) but persistent rumour has it that the figure may be much higher, close to $80 \%$. The ministry also estimates that $68 \%$ of Dar es Salaam residents get "clean water" (ibid). However, the DAWASCO performance report for 2010/2011 shows that it has a total of 109,633 domestic water connections which is estimated to serve 600,000 households in its service area (EWURA, 2012). The report also shows that DAWASCO only serves $18 \%$ of the total number of households within its service area (ibid).

Access to water in Dar es Salaam varies significantly across socio-economic and geographical boundaries. The variation is most pronounced between planned areas, where piped water is in theory available, and unplanned areas, 
where it is not, and between affluent and poor households. In areas where piped water is unavailable, communal projects have been implemented mainly by NGOs. We now describe the four streets where data collection took place.

\section{Masaki and Oyster Bay Streets}

These affluent streets are located along the Indian Ocean peninsula and were inhabited by whites during the colonial period. After independence in 1961, the area was transferred to high profile public officials and diplomats. The construction of multi-storey apartment buildings, office blocks and estates characterize recent developments in the area. As a result, population density is increasing, putting pressure on the old infrastructure including water distribution networks.

\section{Mkunduge and Nyambwera Streets}

These low to middle income areas are located in informal settlements and characterized by unplanned settlement and poor public service. There is a DAWASCO piped water network in Mkunduge but it does not supply water. Nyambwera has no DAWASCO piped water network but a few citizens get DAWASCO water through household resellers from a neighbouring street. Major sources of water in Mkunduge include borehole water vendors, pushcart water vendors, public water kiosks, and mosques. Major sources of water in Nyambwera include public water taps supplied by a community water project, neighbours who own deep water wells, and mosques. In both streets, citizens also get water from shallow wells dug on the river banks and valleys.

\subsection{Results}

A full list of all strategies used by citizens to access water found is presented in Tables 4.3 and 4.4 below, using the parameters listed in Table 4.2. Table 4.3 describes strategies with respect to sources of water, uses and intermediaries, while Table 4.4 describes strategies with respect to intermediaries. Together the tables enable comparison among coping strategies reported by citizens. As indicated, this information was derived from interviews and observations and should not be interpreted as results of a quantitative household survey.

Below, we illustrate the information presented in the tables by selectively describing the most typical strategies for access to water when piped supply is unavailable or failing. We then focus on key intermediaries that mediate citizens' to access water at the 'street' or household level because this aspect of access strategies has been largely overlooked in the literature. We find that water mechanics and water vendors (informal providers) are the most important intermediaries in ensuring access to water for the majority of people. In the discussion and conclusion we take all observed strategies into account. 


\section{TYPICAL CITIZENS' ACCESS STRATEGIES}

\section{Drilling of private deep wells}

Many households connected to piped water also have private deep wells as an alternative source of water during scarcity. Many of these wells provide salty water. In Masaki and Oyster Bay, the wells are mostly used by a single household, while in Nyambwera and Mkunduge the water is sold to neighbours.

\section{Installing water pumps and reserve tanks}

This strategy is common for households who have piped water connections but experience low pressure. Water users cannot be sure when they will have water and whether it will flow long enough to fill their storage facilities. This means that the additional cost of piped water is high. One respondent felt that having a private well is cheaper than piped water from DAWASCO.

\section{Buying water from vendors}

During DAWASCO breakdowns, access to water for most households is through vendors. Masaki and Oyster Bay are served by big motorized tanker trucks while the majority of residents in Mkunduge get water from water resellers who have a private well or piped water connection, pushcart water vendors and water kiosks. Pushcart vendors get their water from a variety of sources: water kiosks, borehole vendors and from household resellers with piped water. Water vending using pushcarts is minimal in Nyambwera. Water tanker trucks are non-existent in the poorer areas.

Water kiosks were originally introduced by DAWASCO as a means to supply water to communities that do not have in-house water connection. The kiosks are run by private agents who in return pay rent to DAWASCO. However, we found that in reality many kiosks do not get water from DAWASCO. Instead, they get water from tanker trucks or illegal connections to DAWASCO pipes.

The price of water sold by vendors in Dar es Salaam varies depending on the sources of water, quality of water and availability. The highest price is for bottled water and ranges between 600 Tsh and $1000 \mathrm{Tsh}^{11}$ (US\$0.38eUS\$0.63) per litre depending on the brand. Next is tap water, which is usually sold at the price of 250 Tsh (US $\$ 0.16$ ) per 20 L bucket during normal situations. However, the price can rise substantially when water is scarce. For instance, the aftermath of DAWASCO's operation to arrest illegal water users in February 2013 (Kisanga, 2013) saw the prices going as high as 700 Tsh (US\$0.44) per bucket due to scarcity. During this time, water had to be collected from distant neighbourhoods.

\footnotetext{
11 US\$1 $1 / 41600$ Tsh
} 
Trucks serving affluent neighborhoods set the minimum amount of water a person can buy to $1000 \mathrm{~L}$, with the price of water decreasing as the amount increases. For instance, the price for $1000 \mathrm{~L}$ of water is 8000 Tsh (US\$5.0) compared to 60,000 Tsh (US $\$ 37.5$ ) for 10,000 L. Table 4.2 below summarizes the price of water in the four study areas. Residents in Masaki showed concern for the quality of water particularly provided by water vendors; the taste of water, i.e. salty or non-salty, is usually the yardstick.

Table 4.2: Price of water in the selected case study areas

\begin{tabular}{|c|c|c|c|c|c|c|c|c|c|c|}
\hline \multirow{3}{*}{ Area } & & \multicolumn{2}{|c|}{ Official Piped water } & \multicolumn{7}{|c|}{ Water vending } \\
\hline & & \multirow{2}{*}{$\begin{array}{c}\text { House } \\
\text { connection } \\
\text { (Tsh/litre) }\end{array}$} & \multirow{2}{*}{$\begin{array}{c}\text { Public } \\
\text { stand } \\
\text { pipes } \\
\text { (Tsh/litres) }\end{array}$} & \multirow{2}{*}{$\begin{array}{c}\text { Stand } \\
\text { pipes } \\
\text { (Tsh/20 } \\
\text { litres) }\end{array}$} & \multicolumn{2}{|c|}{$\begin{array}{c}\text { Pushcart } \\
\text { vendors } \\
\text { (Tsh/20litres) }\end{array}$} & \multirow{2}{*}{$\begin{array}{c}\text { Tankers } \\
\text { (Tsh/litre) }\end{array}$} & \multirow{2}{*}{$\begin{array}{c}\text { Mosques } \\
\text { (Tsh/20 } \\
\text { litres) }\end{array}$} & \multirow{2}{*}{$\begin{array}{c}\text { Sachet } \\
\text { water } \\
(\mathrm{Tsh} / 50 \mathrm{ml})\end{array}$} & \multirow{2}{*}{$\begin{array}{c}\text { Bottled } \\
\text { water } \\
\text { (Tsh/litre) }\end{array}$} \\
\hline & & & & & $\begin{array}{l}\text { Piped } \\
\text { water }\end{array}$ & $\begin{array}{l}\text { Water } \\
\text { from } \\
\text { wells }\end{array}$ & & & & \\
\hline \multirow{2}{*}{$\begin{array}{l}\text { Affluent } \\
\text { streets }\end{array}$} & Oysterbay & 1.077 & - & - & - & - & $6-8$ & - & - & $600-1000$ \\
\hline & Masaki & 1.077 & - & - & - & - & $6-8$ & - & - & $600-1000$ \\
\hline \multirow{2}{*}{$\begin{array}{l}\text { Poor } \\
\text { streets }\end{array}$} & Mkudunge & - & - & $\begin{array}{l}50- \\
500\end{array}$ & $\begin{array}{c}250- \\
700\end{array}$ & $\begin{array}{l}50- \\
200\end{array}$ & 15 & 50 & $20-50$ & $600-1000$ \\
\hline & Nyambwera & - & - & $\begin{array}{l}50- \\
200\end{array}$ & $\begin{array}{c}250- \\
300\end{array}$ & $\begin{array}{l}25- \\
100\end{array}$ & - & 50 & $20-50$ & $600-1000$ \\
\hline
\end{tabular}

\section{Buying water from neighbours}

Some households buy water or get it for free from their neighbours. Various ways are used to transport water between neighbours. Some households get water by connecting plastic pipes while others carry buckets on their heads. Some respondents are not allowed to enter inside the fences and get water from taps outside the fence. Given the high capital requirement for making connections, those who can afford it sell water to their neighbours. This is the main source of water for Mkunduge residents especially for drinking.

\section{Buying water from mosques}

The importance of mosques as water providers is well established in the low and middle income neighbourhoods of the city. Because Muslims are required to perform a ritual washing prior to prayers, almost every mosque is equipped with a deep water well to ensure reliable water supply. Usually, the wells are fitted with electrical pumps to draw water to tanks. Since electricity in Dar es Salaam is not reliable, most of the mosques have bought generators to run the pump during power rationing. Thus, water from the mosque is considered more reliable than other sources affected by power cuts and low voltage. Mosques sell water in order to generate income for maintenance and pay electricity bills. In Nyambwera, the price for water at the mosque is lower than when bought from the community water project or private vendors. 


\section{Buying packaged water}

In all four streets respondents reported the use of bottled water. In high income areas bottled water may also be used for bathing during periods of high water scarcity. In Nyambwera and Mkunduge, households with fridges and freezers sell chilled water from different sources to their neighbours in small plastic sachets averaging between $30 \mathrm{ml}$ and $50 \mathrm{ml}$. The price ranges between 20Tsh and 50Tsh per sachet depending on the availability of electricity and the source of water. Iced sachets made by tap water are sold at a higher price than those made by salty water from wells.

\section{Illegal connections and stealing}

Different forms of illegal water connection or stealing from the DAWASCO network were reported in Masaki and Mkunduge streets. In Mkunduge, people have illegally connected their houses to the DAWASCO water network in nearby areas, since the network exists in Mkunduge but is not functional. One water vendor in Mkunduge explained how he obtained water to sell from about $2 \mathrm{~km}$ using a self-installed pump and pipe. Government authorities including DAWASCO know this type of stealing.

In February 2013, the Ministry of Water (MoW) in collaboration with Dar es Salaam Water and Sewerage Authority (DAWASA) and DAWASCO, carried out a crackdown of illegal water users in Kinondoni municipality (Kisanga, 2013). The crackdown was largely carried out in low and middle-income areas. Police force with machine guns were involved to facilitate arrests and protect public officials against assault. On the first day of the crackdown, the MoW officials apprehended 25 illegal water users most of which were water vendors. That is, citizens were not arrested for selling water but for illegal connection to DAWASCO piped network. There were mixed feelings among citizens regarding the MoW's initiative to fight water crimes. While few supported the initiative claiming that it would improve citizens' access to water, a majority was more pessimistic. In Tandale for instance, citizens were more concerned about the acute water shortage as a direct consequence of the initiative to arrest illegal water users. Following the arrests, the price of water from vendors escalated from a regular price of 250 Tsh (US $\$ 0.16$ ) per bucket $(20 \mathrm{~L}$ ) to about 700 Tsh (US\$0.44). Apparently most citizens felt that the crackdown only singled out illegal users in low and middle income areas hence denying access to water for the poor. In addition, some respondents questioned the sustainability of the initiative.

In Masaki, large water consumers like apartments get water from the "water mafia". The water mafia's first step is to sabotage the water supply system by cutting off the water supply in one way or another. Next, they approach the targeted customers offering their service, ensuring them that they can provide reliable water supply for an agreed fee. Other services offered include 
reconnection of water and fixing long standing debts with the water authority. Discussion with residents from the high income areas revealed that the local government and high level leaders are aware of such practices but they are allegedly colluding with the mafia. Respondents indicated that they do not report the water mafia's practices to officials out of fear of being victimized.

\section{INTERMEDIARIES}

\section{DAWASCO Staff}

Citizens interact with DAWASCO staff officially when applying for new water connections, reporting breakdowns, and payment of water bills. Likewise, DAWASCO water technicians are responsible for managing the water rationing timetable. Many of these processes require physical visits to DAWASCO offices. On the other hand, citizens interact with DAWASCO staff informally, to acquire illegal water connections. In most cases, face-to-face and personal interactions are preferred to virtual communication. One resident in the high income areas explained how they interacted with DAWASCO staff. "...In case of a problem, our father used to drive to DAWASCO offices, and if the problem required physical visit by water mechanics, then he would bring them in his car and drive them back upon finishing their work. Sometimes my mother gave them lunch. They liked my father, whenever he showed up at their offices, they would react without delay" [OY2].

With regards to monitoring illegal use of water, DAWASCO staff is also responsible for arresting people who have installed water pumps. In some cases, illegal water users collude with DAWASCO staff to connect into the water mains or divert water to areas which do not have piped connections. In addition, there are claims that DAWASCO staff tip-off illegal water users about planned operations designed to apprehend them.

\section{Politicians}

Besides fostering representation and participation of citizens, political parties are also considered to play a significant role in influencing access to water of many urban residents. This role is greatly felt within informal and semi-urban areas where piped water connection is lacking. Within these areas, access to water is often through community water projects which are managed by water committees (part of the local government) and overseen by the political leaders such as street chairpersons. In Dar es Salaam, the performance of community water projects in ensuring reliable access of water to citizens greatly depends on the performance of local political leaders (Bourque, 2010). Citizens have high expectations that political leaders will improve access to water within their jurisdictions. 


\section{Water vendors}

Water vendors play an important role in enabling citizens to access water. They operate water kiosks, and sell water from a shallow well, a borehole, a commercial water connection, or a household connection to the piped network (Kjellén \& McGranahan, 2006, p. 2). That is, water vendors act as intermediaries between citizens and other forms of water providers such as DAWASCO or community water projects. In areas with a piped water network, the role of water vendors becomes more significant during DAWASCO breakdowns and stiff rationing. During such periods, water becomes scarce and has to be collected from long distances usually by water vendors. Thus, water vendors relieve citizens from the trouble of walking long distances or spending long hours looking for water. Yet, they extract payments in exchange for the service they deliver to citizens.

\section{Private water mechanics and plumbers}

Private water mechanics provide technical support to citizens regarding water supply system. They give advice on the type and quality of spare parts citizens have to buy, construct water wells and repair piped and non-piped water systems. Very often, private water mechanics fill the gap of DAWASCO water mechanics particularly during long delays and unsuccessful response. Many private mechanics and plumbers work informally without any registration. While many private mechanics can respond quickly, some citizens were concerned about their poor quality of service and dishonesty.

\section{Water Drilling Companies}

Both public and private water drilling companies mediate citizens' access to water. Depending on the quality of water pump, the cost of drilling a water well varies from one area to another, ranging between 5million and 10 millionTsh. The majority of citizens prefer small drilling companies since they are regarded cheaper and less bureaucratic.

\section{House owners}

For the many households who are renting living quarters, their house owners or land lords play a significant role in ensuring their access water. For areas with piped water connections, all the interactions with the utility company are carried out by the land lords, including bill payments and reporting of problems. 
Table 4.3: Access strategies, citizen categories and dimensions of access

\begin{tabular}{|c|c|c|c|}
\hline & Citizens & $\begin{array}{c}\text { Categories of } \\
\text { Strategies }\end{array}$ & Dimensions of Access \\
\hline & ¿ & & \\
\hline Strategy & 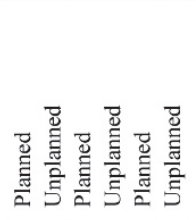 & 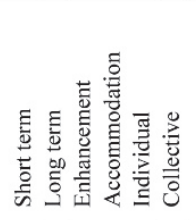 & 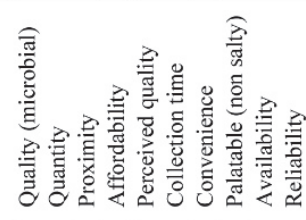 \\
\hline 1 Drilling bore hole for private use & $\bullet \bullet \bullet \bullet$ & $\bullet \bullet$ & $\bullet \bullet \bullet \bullet \bullet \bullet \bullet$ \\
\hline 2 Buying water from push cart vendors & $\bullet \bullet \bullet \bullet$ & $\bullet \bullet \bullet$ & $\bullet \bullet \bullet \bullet \bullet$ \\
\hline 3 Buying water from land lords & $\bullet \bullet \bullet$ & $\bullet$ & $\bullet \bullet \bullet \bullet$ \\
\hline 4 Buying water from DAWASCO kiosks & $\bullet \bullet$ & $\bullet$ & $\bullet \bullet \bullet \bullet \bullet \bullet$ \\
\hline 5 Buying water from community project stand pipe & $\bullet$ & $\bullet$ & $\bullet \bullet \bullet \bullet \bullet \bullet$ \\
\hline 6 Buying water from bore hole vendors & $\bullet \bullet \bullet \bullet$ & $\bullet$ & $\bullet \bullet \bullet \bullet \bullet \bullet$ \\
\hline 7 Buying water from mosque & $\bullet \bullet \bullet$ & $\bullet$ & $\bullet \bullet \bullet \bullet$ \\
\hline 8 Buying water from tanker trucks (in buckets) & $\bullet \bullet$ & $\bullet$ & $\bullet \bullet \bullet \bullet \bullet \bullet \bullet \bullet$ \\
\hline 9 Buying water from tanker trucks (whole sale) & $\bullet \bullet \bullet \bullet$ & $\bullet$ & $\bullet \bullet \bullet \bullet \bullet \bullet$ \\
\hline 10 Buying bottled water & $\bullet \bullet$ & $\bullet \bullet$ & $\bullet \bullet \bullet \bullet \bullet$ \\
\hline 11 Buying bottled water during emergencies & $\bullet \bullet$ & $\bullet$ & $\bullet \bullet$ \\
\hline 12 Installing electric water pump & $\bullet \bullet \bullet \bullet \bullet$ & $\bullet \bullet$ & $\bullet \bullet \bullet \bullet \bullet \bullet \bullet$ \\
\hline 13 House water connection from DAWASCO & $\bullet \bullet \bullet \bullet$ & $\bullet \bullet$ & $\bullet \bullet \bullet \bullet \bullet \bullet$ \\
\hline 14 House water connection from bore hole vendor & $\bullet \bullet$ & $\bullet \bullet$ & $\bullet \bullet \bullet \bullet \bullet$ \\
\hline 15 House water connection from community project & $\bullet$ & $\bullet \bullet$ & $\bullet \bullet \bullet \bullet \bullet \bullet$ \\
\hline 16 Taping broken water pipes & $\bullet \bullet \bullet$ & $\bullet$ & $\bullet \bullet \bullet \bullet \bullet \bullet$ \\
\hline 17 Digging and collecting water from shallow wells & $\bullet \bullet$ & $\bullet$ & $\bullet \bullet \bullet \bullet \bullet \bullet$ \\
\hline 18 Collecting rain water & $\bullet \bullet \bullet$ & $\bullet$ & $\bullet \bullet$ \\
\hline 19 Illegal connection to DAWASCO water network & $\bullet \bullet$ & $\bullet \bullet$ & $\bullet \bullet$ \\
\hline 20 Buying chilled sachet water & $\bullet \bullet \bullet$ & $\bullet \bullet$ & $\bullet \bullet \bullet$ \\
\hline 21 Construction of large storage facilities & $\bullet \bullet \bullet \bullet$ & $\bullet \bullet$ & $\bullet$ \\
\hline 22 Buying water storage containers & $\bullet \bullet \bullet \bullet \bullet$ & $\bullet$ & $\bullet \bullet$ \\
\hline 23 Boiling water & $\bullet \bullet \bullet \bullet \bullet$ & $\bullet \bullet$ & $\bullet$ \\
\hline 24 Waking up at night & $\bullet \bullet \bullet \bullet \bullet$ & $\bullet \bullet$ & $\bullet$ \\
\hline 25 Collecting water from rivers/ponds & $\bullet \bullet \bullet$ & $\bullet$ & $\bullet \bullet$ \\
\hline 26 Multiple use of water (washing then flashing toilets & $\bullet \bullet$ & $\bullet \bullet$ & $\bullet \bullet$ \\
\hline 27 Constructing pit latrines that do need flashing & $\bullet \bullet \bullet \bullet$ & $\bullet \bullet$ & $\bullet$ \\
\hline 28 Bathing with bucket & $\bullet \bullet \bullet \bullet$ & $\bullet \bullet$ & - \\
\hline
\end{tabular}


Table 4.4: Access strategies, sources of water, uses and intermediaries

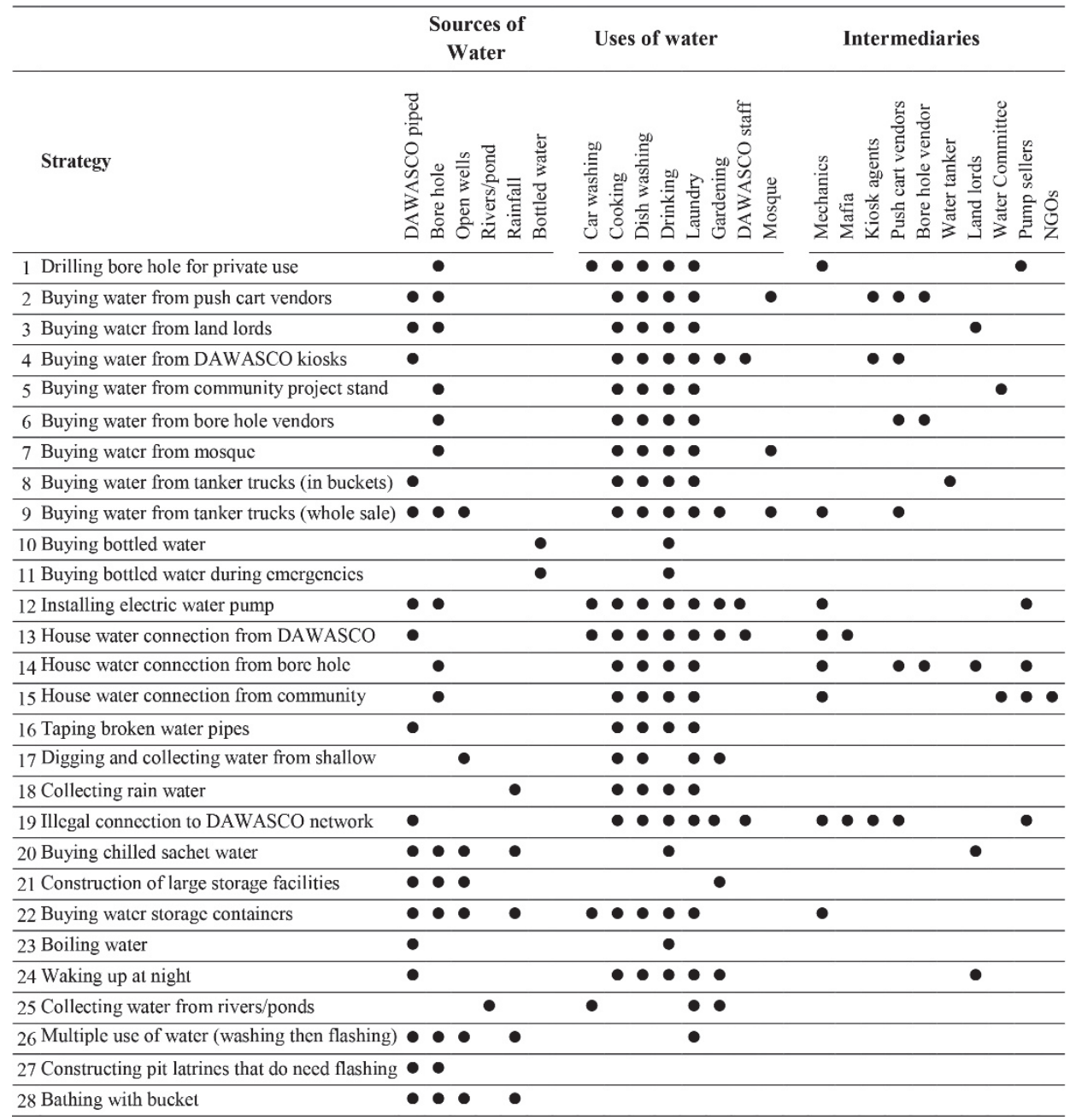

\subsection{Discussion: what do access strategies solve for whom?}

One access strategy can solve more than one access problem. For instance, buying water from vendors caters for problems of quantity, quality and convenience, particularly if the vendor has collected water from a public piped system. Not every citizen is able to use all access strategies; therefore, not all citizens can solve all access problems to the same extent and with the same ease. Access strategies vary significantly between planned and unplanned areas and between affluent and poor households. Rich citizens in planned areas use long term strategies while poor citizens in unplanned areas use a variety of short term strategies in parallel and over time. Short term access strategies, 
when used for decades, become in a sense long term. For instance, while citizens may choose a different type and/or location of vendors, they are likely to continue buying water for the greater part of their lives.

Long term access strategies require more complex transactions with a number of intermediaries. They raise (non-monetary and monetary) entry costs and render accessibility prohibitive for the poor. In addition to official procedures and payments required when applying for piped water connection, citizens are also compelled to make unofficial transactions in order to speed up the process. Similarly, communal strategies have high start-up costs. Setting up a functional community water project takes a very long time, including complex processes of mobilizing citizens, government authorities, NGOs, and many other stakeholders. Over time, citizens lose hope and trust towards the government, especially if they have to pay a contribution that subsequently disappears. These high transaction costs (time, money and other resources) to access official improved drinking-water sources encourage the proliferation of informal water providers and incentivise corruption within official providers.

On the one hand, citizens acknowledge the lack of capacity of public water providers to provide adequate services and resort to informal and private efforts. In such conditions, "survival of the fittest" modalities become the norm and those in need of assistance communicate with closely related individuals and networks. Likewise, those with resources see the opportunity to benefit from the gap created by the public water providers. As a result, a variety of water vendors is created that partly explain why citywide protests are largely inexistent. On the other hand, widespread knowledge of the lack of capacity of public water provides is an incentive for utility staff to not only become indifferent to reported problems but also to cash in money from water users. Similarly, politicians use this knowledge as a cheap political point-scoring capital during elections. Promises to end Dar es Salaam water woes have been getting higher coverage in the past two presidential elections without fruitful results (Daily News, 2010; The Guardian, 2005). Persistently unfulfilled promises and delayed official responses to water problems induce citizens to adopt long term access strategies such as drilling deep wells.

\section{Solving water quantity and quality problems}

The findings reveal that most access strategies are geared towards increasing only the quantity of water. Except when bottled commercially, water in Dar es Salaam is unsafe for drinking. Incidence of diseases like typhoid and frequent outbreak of cholera were common among citizens in the last decade (Penrose et al., 2010). In addition, Kassenga (2007) also found a high degree of contamination in the public piped water. Many citizens therefore prefer bottled water for drinking when they can afford it. The majority of interviewed citizens were very aware about the health risks connected to drinking tap water. 
However, they do not generally improve the microbial quality of water by boiling or using household water treatment technologies. In most cases, water from boreholes is perceived as safe to drink, while this is usually not the case, so citizens are likely to boil water from DAWASCO and not water from boreholes. However, many citizens do not desire water from boreholes for drinking because it is salty. In high-income areas, piped water is used for gardening and household tasks, while in low-income areas irrigation is done using water from open wells and rivers.

\section{Solving reliability and proximity problems}

Due to limited storage facilities, poor households feel the absence of water immediately. Moreover, given that most people get water from vendors in buckets or jerry cans, reliability of supply does not mean that water is available 24/7. Instead, citizens consider a source as reliable when water is available when they need it. For instance, although most borehole vendors sell water only during the day, they may own electricity generators that pump water during power outbreaks to ensure supply. Most citizens living in low and middle income areas asserted that water from mosques is more reliable than from a community project. While official statistics emphasise the proximity of water sources, e.g. a distance of $400 \mathrm{~m}$, this metric is irrelevant for citizens who get water from vendors. Long distances travelled by water vendors are only indirectly felt by citizens through increase in prices, especially when water is scarce.

\section{Solving other problems}

In addition to the four types of problems identified by Kristof's (2005), we identified the time of collection as a major concern. Many citizens who are connected to piped water are forced to wake up at night to fill up reservoirs or do their washing as that is the only time when water is flowing. In Mkunduge, a citizen reported that they collectively wake up at night to help their water vendor reconnect her piped water network at one of DAWASCO's distribution valves.

\subsection{Conclusion}

Access to water in Dar es Salaam is influenced by a variety of factors depending on households' demand for water and the source of water they can possibly afford. However, being connected to a piped water system does not guarantee a reliable water supply. More often, citizens cannot access water without private efforts to install water pumps or by colluding with water utility staff.

The findings show that access to water for the urban population in Dar es Salaam is influenced by factors beyond the water sector, such as systemic corruption, regular electricity breakdowns, weak accountability, political capture of water policies and projects. Citizens' day-to-day efforts to access 
water are constrained by petty corruption and illegal practices. Both grand and petty corruption in the water sector significantly impact citizens' access to water negatively, however, effects of petty corruption are directly felt in dayto-day life experiences of citizens. In Tanzania, petty corruption is considered by many as the way of life. One newspaper opinion observes that people expect to be asked for a bribe as "...the briber has an impulse of giving before even being asked to do so..." (Nyoka, 2013). Although petty corruption enables some Dar es Salaam citizens to access water, it disables many others who cannot afford it particularly the poor. Despite the efforts by the government to combat corruption in the public sector, by establishing the Prevention and Combating of Corruption Bureau in 2007, its impacts have not been realized particularly at the grassroots level. Widespread petty corruption in the water sector has also been observed in earlier studies outside Tanzania (van Dijk, 2011; Zinnbauer \& Dobson, 2008). Still, petty corruption especially the kind exercised by the water mafia, often receives a good coverage in newspapers (Devanathan, 2013; Diani, 2009; Eichenseher, 2008).

The study has found that the capacity of public services and NGOs to provide enough water is limited, and the quality of water provided leaves a lot to be desired. Informal and small scale private service providers fill the gap at least as far as quantity is concerned. Therefore, when assessing access to water for the purpose of policy making it needs to be recognised that "actual water deliveries may better reach end-users through commercialised and decentralised organisational forms" (Kjelle' $\underline{n}, 2006$ : 237). Conventional wisdom may suggest that a possible solution for better access for all citizens would be to recognize and regulate the multiple informal providers that occupy the blurred space between citizens and water officials. However, widespread corruption practices in the water sector are likely to undermine regularization efforts. Any regularization approach will probably raise the cost of water from private providers due to bribes demanded by regulators. Alternatively, neoliberal rationality would suggest privatization of the water sector to induce massive capital investment for the infrastructure and sustainability through cost-recovery. However, a failed government attempt in 2003 to privatize water supply in Dar es Salaam (Pigeon, 2012) suggests that such interventions are not always effective. Overall, widespread corruption and existence of water mafias are likely to halt any efforts to improve access to water in Dar es Salaam. Only alternative solutions that universally provide what matters most to citizens e accessing adequate, reliable and affordable water may successfully challenge the existing syndicate of mafias and their networks that currently benefit from the problems of water sector.

We conclude that official statistics of access to water are only partially relevant for the actual situation regarding water access, because on the one hand, they leave out some important problems of access, and on the other hand they 
ignore the fact that informal private water selling activities in fact constitute the majority of access strategies. These findings are in line with (ObengOdoom, 2012; Satterthwaite, 2003) who argue that official statistics do not fully represent the reality on the ground. For instance, walking distance to a source may not mean anything if the source do not provide water. Similarly, because many citizens get water at their doorstep from vendors, they are not interested in distance to a source but rather in the price they pay to the vendor. Given that water vending is considered illegal (unless organised by DAWASCO or another recognised entity), the way access is counted in effect reinforces state/NGO monopolies.

Findings of this study are also noteworthy and opportune for the post-2015 agenda discussions (Satterthwaite \& Mitlin, 2013; Stoler, 2012) particularly in ensuring targets and monitoring structures of the next global development framework takes into account what matters most to citizens. As noted in the introduction, the attention to date has been on reporting aggregate coverage rates than investing into realizing improvements on access to water as registered by citizens. In other words, the new interventions should aim at resolving day-to-day hardships experienced by water users. This requires adjustments in the approaches in the design and implementation of water interventions.

A further study with more focus on further understanding of day-to-day practices of some of the intermediaries who benefit from the current water problems is therefore suggested. It is possible that these intermediaries have higher incentive to sabotage any efforts to improve water supply in Dar es Salaam. More broadly, research is also needed to ascertain power relations among key players such as water mafia and their impact to the water supply in the city.

Problems of water in Dar es Salaam are complex and a 'silver bullet' solution is unrealistic. The current findings add substantially to our understanding of what matters most to citizens - accessing adequate, reliable and affordable water. Informal and private means to access water in Dar es Salaam will remain important for many households for the near future. Therefore, the contribution of informal and private ways to access to water needs to be acknowledged and included in official studies and statistics on access to water. For (Kjellén, 2006, p. 236), "the efficiency of water systems may be substantially enhanced by supporting the agents actually working in the sector, rather than ignoring or obstructing their practices". These efforts would be especially beneficial for poor households who are now at risk of consuming poor quality water at exorbitant prices. 


\section{References}

Adeniji-Oloukoi, G., Urmilla, B., \& Vadi, M. (2013). Households' coping strategies for climate variability related water shortages in Oke-Ogun region, Nigeria. Environmental Development, 5(0), 23-38. doi: http://dx.doi.org/10.1016/j.envdev.2012.11.005

Bourque, E. C. (2010). Urban Governance and Unequal Geographies of Water in Buguruni Ward, Dar es Salaam, Tanzania (PhD in Geography), Kings College London, London, UK.

Bryman, A. (2012). Social Research Methods (Fourth Edition ed.). New York, USA: Oxford University Press.

Cheng, D. (2013). (In)visible urban water networks: the politics of nonpayment in Manila's low-income communities. Environment and Urbanization, 25(1), 249-260. doi: 10.1177/0956247812469926

Daily News. (2010, 20 July). End of Dar es Salaam water blues in sight, Daily News.

Devanathan, V. (2013, 5th August). Water mafia cashing in on water scarcity, Collections - Water Crisis, The Times of India. Retrieved from http://articles.timesofindia.indiatimes.com/2013-08-

05/madurai/41091546_1_water-mafia-water-tanker-operatorspackaged-drinking-water

Diani, H. (2009, 24th July). Pay Up: How the Water Mafia Controls Access, JakartaGlobe.

Retrieved from http://www.thejakartaglobe.com/archive/pay-up-how-the-water-mafiacontrols-access/

Eichenseher, T. (2008). Water Mafias" Put Stranglehold on Public Water Supply, National Goegraphic news. Retrieved from http://news.nationalgeographic.com/news/2008/08/080821-watermafias.html

EWURA. (2012). Water Utilities Performance Report 2010/2011: Regional Water Utilities and DAWASCO. Dar es Salaam, Tanzania: Energy and Water Utilities Regulatory Authority (EWURA).

Guest, G., Bunce, A., \& Johnson, L. (2006). How Many Interviews Are Enough?: An Experiment with Data Saturation and Variability. Field Methods, 18(1), 59-82. doi: 10.1177/1525822x05279903

Gundry, S. W., Wright, J. A., Conroy, R., Du Preez, M., Genthe, B., Moyo, S., Mutisi, C., Ndamba, J., \& Potgieter, N. (2006). Contamination of drinking water between source and point-of-use in rural households of South Africa and Zimbabwe: implications for monitoring the Millennium Development Goal for water. Water Practice and Technology, 1(2).

Hackenbroch, K., \& Hossain, S. (2012). "The organised encroachment of the powerful"-Everyday practices of public space and water supply in Dhaka, Bangladesh. Planning Theory \& Practice, 13(3), 397-420. doi: 10.1080/14649357.2012.694265 
Kassenga, G. R. (2007). The health-related microbiological quality of bottled drinking water solid in Dar es Salaam, Tanzania. Journal of Water and Health, 5(1), 179-185. doi: Doi 10.2166/Wh.2006.052

Kayaga, S., Fisher, J., \& Franceys, R. (2009). Improved access to urban water services in Uganda. Proceedings of the Institution of Civil Engineers: Municipal Engineer, 162(3), 165-170.

Kisanga, D. (2013, 27 February). Hunt for water thieves in Dar starts on high note, News, The Guardian. Retrieved from http://www.ippmedia.com/frontend/index.php?l=51708

Kjellén, M. (2006). From Public Pipes to Private Hands: Water Access and Distribution in Dar Es Salaam, Tanzania (Illustrated ed.). Stockholm, Sweden: Department of Human Geography, Stockholm University.

Kjellén, M., \& McGranahan, G. (2006). Informal Water Vendors and the Urban Poor Human Settlements Discussion Paper Series London, UK: International Institute for Environment and Development (IIED).

Kristof, B. (2005). Monitoring of Water Supply Coverage. WELL fact sheet. Retrieved 25/07, 2013, from http://www.lboro.ac.uk/well/resources/factsheets/fact-sheets-htm/mwsc.htm

Kudat, A., Bell, M. E., Boland, J. J., Humplick, F., Madanat, S., \& Mukherjee, N. I. (1993). Reliability of Water Supply in Developing Countries: The Emperor Has No Clothes. Washington, DC: The World Bank.

Kyessi, A. G. (2005). Community-based urban water management in fringe neighbourhoods: the case of Dar es Salaam, Tanzania. Habitat International, 29(1), 1-25. doi: 10.1016/s0197-3975(03)00059-6

National Bureau of Statistics. (2013). 2012 Population and Housing Census: Population Distribution by Administrative Areas. Dar es Salaam, Tanzania: United Republic of Tanzania.

Nyarko, K. B., Odai, S. N., Owusu, P. A., \& Quartey, E. K. (2008). Water Supply Coping Strategies in Accra. Paper presented at the 33rd WEDC International Conference: Access to Sanitation and Safe Water: Global Partnerships and Local Actions, Accra, Ghana. http://wedc.lboro.ac.uk/resources/conference/33/Nyarko_K2_GHA.pdf

Nyoka, K. w. (2013, 24th August). Tanzania: Institutionalising Corruption Any Hope of Taming It?, Opinion, Daily News. Retrieved from http://www.dailynews.co.tz/index.php/columnists/columnists/21413institutionalising-corruption-any-hope-of-taming-it

O'Hara, S., Hannan, T., \& Genina, M. (2008). Assessing access to safe water and monitoring progress on MDG7 target 10 (access to safe water and basic sanitation): Lessons from Kazakhstan. Water Policy, 10(1), 1.

Obeng-Odoom, F. (2012). Beyond access to water. Development in Practice, 22(8), 1135-1146. doi: 10.1080/09614524.2012.714744

Pattanayak, S. K., Yang, J.-C., Whittington, D., \& Kumar, K. C. B. (2005). Coping with unreliable public water supplies: Averting expenditures by 
households in Kathmandu, Nepal. Water Resources Research, 41(W02012).

Penrose, K., Castro, M. C. d., Werema, J., \& Ryan, E. T. (2010). Informal Urban Settlements and Cholera Risk in Dar es Salaam, Tanzania. PLoS Neg/ Trop Dis, 4(3), e631. doi: 10.1371/journal.pntd.0000631

Pigeon, M. (2012). From Fiasco to DAWASCO: Remunicipalising Water Systems in Dar es Salaam, Tanzania. In M. Pigeon, D. A. McDonald, O. Hoedeman \& S. Kishimoto (Eds.), Remunicipalisation: Putting Water Back into Public Hands. Amsterdam, The Netherlands: Transnational Institute.

Rasmus Heltberg, N. H., Anna Reva. (2012). Living through Crises: How the Food, Fuel, and Financial Shocks Affect the Poor. In N. H. Rasmus Heltberg, Anna Reva (Series Ed.) Retrieved from http://issuu.com/world.bank.publications/docs/9780821389409

Satterthwaite, D. (2003). The Millennium Development Goals and urban poverty reduction: great expectations and nonsense statistics. Environment and Urbanization, 15(2), 179-190. doi: $10.1177 / 095624780301500208$

Satterthwaite, D., \& Mitlin, D. (2013). A future that low-income urban dwellers want, and can help secure. London, UK: International Institute for Environment and Development (IIED).

Stoler, J. (2012). Improved but unsustainable: accounting for sachet water in post-2015 goals for global safe water

Communication brève: Améliorée mais non durable: Place de l'eau en sachet dans les objectifs mondiaux pour l'eau sure après 2015

Comunicación corta: Mejora si, pero insostenible: Teniendo en cuenta el agua envasada en bolsas dentro de los objetivos posteriors al 2015 de un agua segura a nivel global. Tropical Medicine \& International Health, 17(12), 1506-1508. doi: 10.1111/j.1365-3156.2012.03099.x

The Guardian. (2005, 25 November). Kikwete promises to end Dar water woes, The Guardian.

Twaweza. (2008). Fostering an Ecosystem of change in East Africa through Imagination, Citizen Agency and Public Accountability Twaweza Strategy. Dar es Salaam, Tanzania: Twaweza.

UNICEF/WHO. (2012). Progress on drinking water and sanitation: 2012 Update. New York: WHO/UNICEF Joint Monitoring Programme for Water Supply and Sanitation.

United Republic of Tanzania. (2010). Mwongozo Kuhusu Uundaji na Usajili wa Vyombo aya Watumiaji Maji Vijijini (Guidelines for Establishment and Registration of Community Owned Water Supply Organisations). Dar es Salaam, Tanzania: Ministry of Water.

United Republic of Tanzania. (2013b). Water sector budget for the financial year 2013/2014. Dar es Salaam, Tanzania: Ministry of Water.

United republic of Tanzania. (2013c). The water sector status report 2013. Dar es Salaam, Tanzania: Ministry of Water. 
van Dijk, T. (2011). Networks of Urbanization in Two Indian Cities. Environment and Urbanization Asia, 2(2), 303-319. doi: 10.1177/097542531100200211

Virjee, K., \& Gaskin, S. (2010). Coping with poor water services and the demand for change in Trinidad and Tobago. Water International, 35(3), 285-297. doi: 10.1080/02508060.2010.487299

Yin, R. K. (2011). Qualitative Research From Start to Finish. New York, U.S.A: The Guilford Press.

Zawahri, N., Sowers, J., \& Weinthal, E. (2011). The Politics of Assessment: Water and Sanitation MDGs in the Middle East. Development and Change, 42(5), 1153-1178. doi: 10.1111/j.1467-7660.2011.01730.x

Zérah, M.-H. (2000). Household strategies for coping with unreliable water supplies: the case of Delhi. Habitat International, 24(3), 295-307. doi: http://dx.doi.org/10.1016/S0197-3975(99)00045-4

Zinnbauer, D., \& Dobson, R. (Eds.). (2008). Global Corruption Report 2008: Corruption in the Water Sector. New York, USA: Cambridge University Press. 


\section{Chapter 5}

\section{If citizens protest, do water providers listen? Water woes in a Tanzanian town ${ }^{12}$}

12 This chapter is based on Nganyanyuka, K., Martinez, J., Lungo, J., \& Georgiadou, Y. (2017). If citizens protest, do water providers listen? Water woes in a Tanzanian town. (In the second round of review) 


\begin{abstract}
Tanzania's urban citizens are still insufficiently supplied with safe drinking water by their water utilities. However, instead of collectively clamouring for improvements, citizens channel their protest individually to water authorities. Our aim is to understand citizens' protest strategies and the response they elicit from the water authorities. We draw on extensive fieldwork carried out in a small Tanzanian town. We bring about four protest strategies employed by citizens-"stay and speak up", "speak up and leave", "resignation" and "leave and remain silent." The study reveals a substantial mismatch between citizens' protest strategies and the formal/informal complaint mechanisms of the water authority, with negative implications, for underprivileged citizens and for the revised definition of "access to water".
\end{abstract}

Key words: Citizens' protest, voice, exit, urban water supply, water customer, Tanzania

\title{
5.1 Introduction
}

Public water services in Tanzania have failed urban citizens. Coverage and access is now worse than in $1990^{13}$ despite the legal obligation of water utilities to be service-oriented and economically viable. The final Millennium Development Goal (MDG) assessment for Tanzania is "limited or no progress" while the percentage of urban population with piped water dropped from 31\% in 1990 to $28 \%$ in 2015 (UNICEF/WHO, 2015a). ${ }^{14}$ Sarah L. Smiley (2016) concluded that "Tanzania's water landscape is unjust, unequitable and uneven." The population in low income urban areas ${ }^{15}$ is forced to rely on informal providers offering water of uncertain quality at unregulated high prices (Nganyanyuka et al., 2014).

The "access to water" definition ${ }^{16}$ of Sustainable Development Goal 6 (SDG 6)-"ensure availability and sustainable management of water and sanitation for all" by 2030-will aggravate this problem. SDG 6 extends the MDG focus of "use of an improved source of drinking water" to sustainable management and universal access. The SDG indicator "percentage of population using safely

\footnotetext{
13 UNICEF/WHO. (2015). Progress on Sanitation and Drinking Water: 2015 Update and MDG Assessment. United States of America: UNICEF and the World Health Organization. ${ }^{14}$ As Satterthwaite (2016) shows, these figures understate the problem as the definition used to measure who uses drinking water sources on premises does not contemplate water quality (water is safe to drink) or "sustainable access" (reliable water supply).

15 It should be noted that aggregate statistics also hide the condition of the most marginalized and low-income communities; see Cheng (2013).

16 For a critical perspective on water access indicators - what is being counted (how access is defined) and how it is being counted (are data accurate) see Nganyanyuka et al. (2014) and Satterthwaite (2003).
} 
managed drinking water services" refers to the "population using an improved drinking water source which is located on premises, available when needed and free of faecal (and priority chemical) contamination"17 (WHO-UNICEF, 2015). However, accessing water from improved sources "when needed" remains a challenge even for those with piped drinking water on the premises. Furthermore, the principle of universality is undermined when the water authority only listens and responds positively to citizens who are better-off. Monitoring progress towards SDG 6 will probably remain a challenge in lowand middle-income nations. ${ }^{18}$ Yet, a better understanding of citizens' protest strategies could help in assessing to what extent local water providers are listening and committed to improve access to water.

Studies in sub-Saharan Africa (Furlong, 2010; Marson \& Savin, 2015) documenting the interplay between government neglect and civilian protest (Aubriot, 2014; Gwebu, 2002) concentrate on macro and structural issues (e.g. neoliberal reforms). In Tanzania, the focus has also been on processes of urbanization, responding to poor access to water in formal and informal settlements (Kombe, 2000, 2005). Studies across Tanzania have shown that collective protest as a response to declining service delivery is rare (Hydén, 1980, 1999; Kjellén, 2006). More recently, Hooper and Ortolano (2012) found that slum dwellers' motivation in Dar es Salaam to participate in urban social movements was minimal for renters and significantly higher for property owners and further argued that citizens with no opportunities to express discontent often ended up in "deep resignation". While these studies may touch upon the behaviour of Tanzanian citizens towards deteriorating services, they do not help in explaining the effectiveness of individual citizens' protest strategies in their micro-level encounters with water officials. Unless we understand these micro-strategies and their effect on service improvement, we will not be able to amplify them with information and communication technologies (ICTs), as the influential World Development Report (World Bank, 2003) and other authors claim (World Bank, 2016). ${ }^{19}$ ICTs do not by-pass or undermine service providers but are typically effective when they operate through them (Fung et al., 2011; Welle et al., 2016). As Toyama (2016) argued, it is citizens' "voice, not the technology, which is the primary cause of change" (p. 30).

\footnotetext{
17 The proposed version of February 2015 included "and/or regulated by a competent authority" (United Nations, 2016).

18 Low- and middle-income nations lack adequate data gathering systems to monitor provision for water. When policy mandates targeting under serviced areas, locational information on "who has inadequate provision and where they live" is more relevant than current aggregated indicators at national or city level. See (Satterthwaite, 2003).

19 The UN sees ICT as "essential to achieve the 17 Sustainable Development Goals" see United Nations (2015).
} 
Inspired by Hirschman (1970), we ask "which strategies do citizens use to protest the failure of urban water services and how do water providers respond?" We focus on micro-level, face-to-face encounters between citizens as urban water consumers and front-line officials of the urban water authority in Mashujaa, a small Tanzanian town. The rest of the paper is organized as follows. Section 5.2 outlines the empirical context. Section 5.3 describes the theoretical approach and research methods. Results are presented in section 5.4 , followed by discussion and conclusions in section 5.5 .

\subsection{Empirical Context}

This section describes Mashujaa (a fictitious name for a Tanzanian town), the Mashujaa Urban Water Supply Authority (MUWSA), the history and current state of MUWSA's piped water network and MUWSA's official complaint mechanism.

\section{a. Mashujaa town}

Mashujaa is the capital and main commercial centre of one of the poorest districts in Tanzania. Half of its population of about 50,000 is under 15 years, according to the 2012 national census. Apart from a few affluent citizens active in wild-life tourism, most citizens depend on petty commerce for their livelihood, or work for local government. Mashujaa town comprises three main residential areas, the town centre, the periphery and the outskirts, of which only the first two are now served with MUWSA's piped water, and thus relevant here. The town centre includes small markets and public services such as schools, health facilities, banks, and a police post, old houses, and new hotels and tourist lodges. The periphery's dispersed houses are fused with small farms or bushes and includes MUWSA's headquarters.

\section{b. MUWSA}

MUWSA became the official water provider in Mashujaa town in response to Tanzania's decentralization policy (Venugopal \& Yilmaz, 2010) and the National Water Policy of 2002 (NAWAPO) (United Republic of Tanzania, 2002b). The latter aimed to transform water utilities into efficient service providers focused on operational and financial sustainability. The town's aging piped water network was constructed in the early 1970s. It was "designed to serve the town for a period of 20 years" (MUWSA Manager), but is still serving a growing town population. By the end of the first quarter of 2015, the water authority was serving only $30 \%$ of the targeted population due to low water production capacity caused by power cuts and intermittent breakdowns of the main pump extracting water from a nearby lake. Ideally, it should expand its service to $100 \%$ of the targeted population in order to fulfil one of the national performance criteria for urban water authorities (EWURA, 2016). MUWSA's 
water supply suffers from low pressure, frequent supply interruptions and poor water quality.

While the raw water source is heavily polluted, water treatment facilities are absent. The water authority faces high energy costs caused by worn out infrastructure and the long distance from the water source. The total monthly electricity pumping cost is four times the monthly water sales revenue. The water transmission main from the water intake to the water storage tanks has been vandalised, either to acquire valuable metal resources and sell it for profit, or for ideological reasons (to draw attention to chronic water supply issues) or out of diffuse frustration and even rage. It is impossible to know why without a police investigation of the reasons for vandalism, which does not appear to be forthcoming. Almost sixty percent of the produced water is unaccounted for. About half is lost in leakages and only 33\% is accounted for in customer billings. Currently MUWSA's operation and maintenance costs are paid by the district council through grants from central government. Almost $90 \%$ of its electricity bills is financed by the district council. Still, MUWSA is highly indebted to its suppliers including the national electricity provider.

The water authority manages about 1,000 domestic connections serving 10,000 customers. It supplies water to 40 institutions (including a district hospital) and 50 businesses amounting to 10,000 and 5,000 people, respectively. In 2009, the government funded a project, now falling well behind schedule, to rehabilitate the water network. At the time of fieldwork (Spring 2015), most of the equipment had been acquired but only the first phase of construction had been completed. Initially, the new water project had raised hopes among water customers, but were quickly dashed and changed to cynicism. In May 2015, the project was inaugurated although water was not flowing yet, a strategy critics dubbed as "buying votes" given that national presidential elections in Tanzania were scheduled for October 2015.

\section{c. MUWSA's water billing process}

Eager to increase revenues despite the bleak state of affairs, MUWSA officials attempted to improve the billing system and fee collection by digitizing it. However, they could only secure enough funds to hire an inexpensive but inexperienced university student. The electronic billing system he developed did not live up to expectations and was quickly abandoned. Most of the billing is still conducted manually. Only the printing of bills and receipts is electronic. It involves day-to-day interactions of customers and officials and includes (i) collecting information about water consumption, (ii) preparing water bills, (iii) distributing water bills to customers, and (iv) collecting water fees. "Meterreaders" visit customers' houses monthly and record the readings on paperbased water meter books. Upon the meter-readers' return to the office, water technicians enter the readings into a computer. The business manager 
prepares the bills and prints two copies, one for the customer, one for internal filing. Bill attendants and meter-readers inspect them for mistakes, and sort them for house-to-house distribution according to water distribution zonesthe town centre and the periphery.

\section{d. MUWSA's formal customer complaint mechanism}

MUWSA's Commercial and Customer Care Department records and follows-up on complaints and is responsible for resolving conflicts between customers and MUWSA staff. A secretary, reporting to the business manager, handles customer care: "We had a very smart lady. She was a university graduate, so her salary was higher than most of the staff here [out of a total of 15 MUWSA staff, only two have university education]. Many staff members were unhappy about that, so they conspired to frustrate her. After only few months she could not take it anymore, she left. Since then, we have not been able to get someone to deal with customer complaints" (MUWSA official).

MUWSA reports on its performance monthly to the Ministry of Water, and on a quarterly basis to the Energy and Water Utilities Regulatory Authority (EWURA). In 2015, EWURA ranked the performance of MUWSA in the lowest (E - unsatisfactory) of five performance categories, along with 22 more urban water utilities out of a total 69 in Tanzania. The department maintains a paperbased customer complaints register: "To enable MUWSA to enhance customer satisfaction and retention, we need to ensure that customer complaints are received and registered, then routed to the appropriate department. And we need to be able to track the resolution of customer complaints and give appropriate feedback to customers" (MUWSA Business Manager).

The complaint register includes the name and address (recorded as a street name) of the customer, date of lodging and description of the complaint, and the name of the official assigned to handle it. It includes columns for the date of complaint resolution, the handling official's signature and a "remarks" column describing how the complaint was handled. In practice, complaint handling is rarely recorded in the "remarks" column. An examination of 67 registered complaints showed that 88 percent of the "remarks" column was empty. Nevertheless, some follow-up occurs informally, when a customer meets a water official face-to-face for other matters.

Customers raise complaints through letters, telephone, email and personal visits. Since the water authority lacks a dedicated phone line for customer complaints and given the town size, customers know the mobile phone numbers of officials and vice versa, officials call customers particularly for billing and water fee collection. Customers' phone numbers are important proxies of their physical addresses for the water authority. 


\subsection{Theoretical approach and methods}

MUWSA's water infrastructure loses $60 \%$ of produced water and uses three times more staff than EWURA's service level benchmark to produce and distribute a certain amount of water, making it at least double as expensive as necessary. Customers are forced to pay for a dilapidating and vandalised infrastructure and an overstaffed bureaucracy. This is the kind of organisational deterioration that should trigger a response from the organisation's customers. Hirschman (1970) in his seminal treatise, Exit, Voice and Loyalty, suggested that members or customers of an organization, whether a business, a nation or any form of human grouping, have two possible responses when they perceive that the organization they depend on is deteriorating in quality: they can either withdraw from the relationship with the organization (exit), or, attempt to improve the relationship through communication of the complaint, grievance or proposal for change (voice).

Young (1974) argued that voice is more efficient than exit when (i) the service provider is a monopoly making exit costly, (ii) the public services cannot be differentiated (both poor and affluent customers get the same water from the piped scheme) and those with weak voice gain from the vocal few, and (iii) the service is ill-defined and therefore difficult to evaluate. Paul (1991); (Paul, 1992) argued that inhibitors to voice are: (i) informational asymmetries, e.g. when service providers possess information not available to the public, (ii) the government's ability to restrict the public's access to information, (iii) legal and institutional barriers e.g. some user groups are not recognized and are denied the right to sue public service providers, and last but not least, (iv) social barriers (lack of income and education) limiting the ability to use voice. Exercising voice has dividends for voicers.

Voice is an information rich form of preference expression, a rewarding activity in its own right and scalable from domain to domain. A citizen's acquired skill to exercise voice to complain for water services can be applied to other services as well. An important aspect of Hirschman's argument is that customers combine exit and voice in their effort to improve organizational performance, because exit and voice are not mutually exclusive (Barry, 1974). Last but not least, exit and voice combinations are multiple and can vary in intensity and form (Keeley \& Graham, 1991). It is precisely these multiple voice-exit combinations (protest strategies) that we set out to capture using the 2dimensional plane defined by EXIT and VOICE axes in Figure 5.1. The figure shows two divisions for each axis: Stay and Leave for EXIT and Speak up and Remain Silent for VOICE, dividing the plane in 4 cells. 


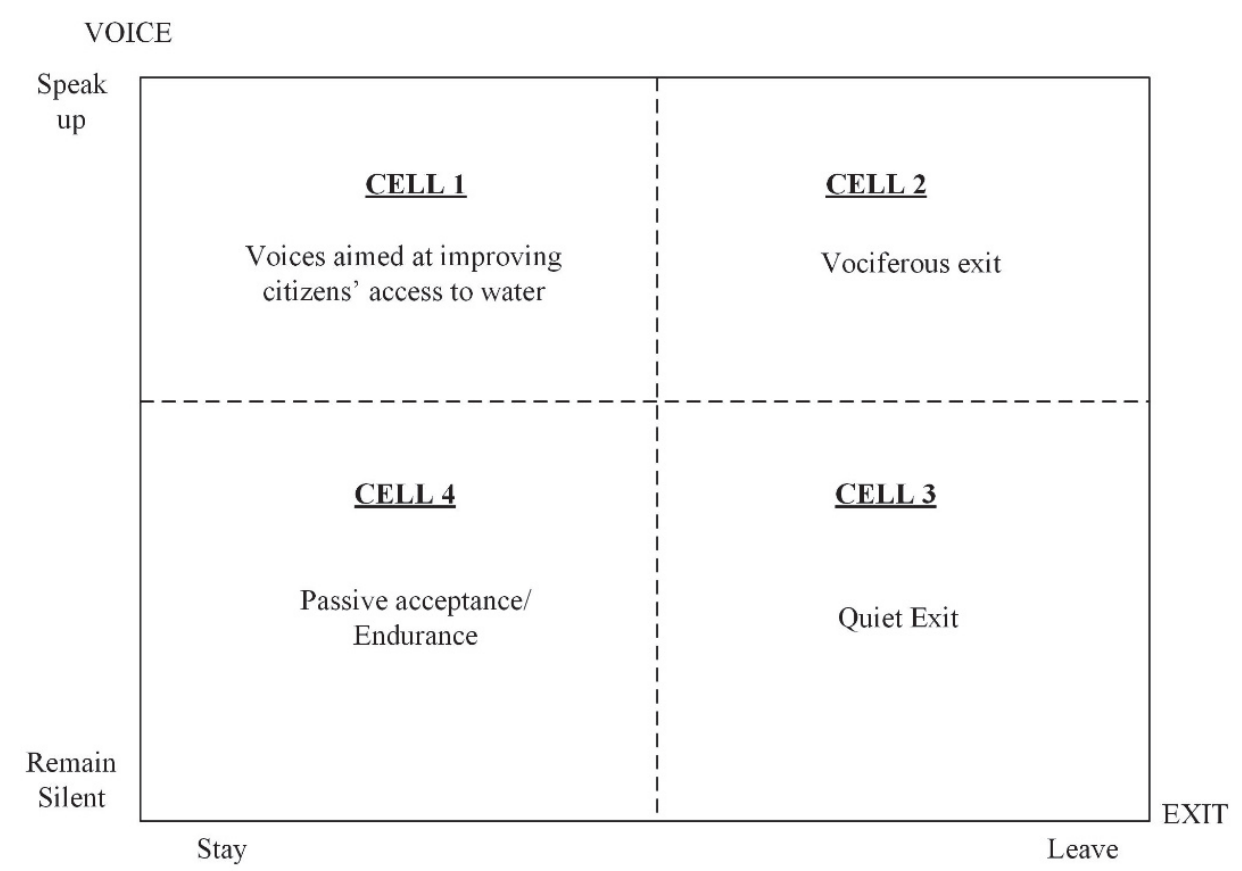

Figure 5.1: Potential customer responses to a service providers' decline. Source: Adapted from Keeley and Graham (1991).

Research methods included in-depth interviews and participant observation with 12 citizens and eight MUWSA officials, in 2014 (1 month) and 2015 (2 months). The MUWSA water manager introduced us to the business manager, revenue collector cum cashier, technical manager, two water technicians, and two water meter-readers. The citizen informants are piped water customers and reside either in the town centre or in the periphery. They either work for local government, and secure a low but stable salary, or depend on petty trading for their livelihood, and are relatively economically disadvantaged. The few affluent citizens in the town have their own improved water sources (wells) and are not MUWSA customers. The officials allowed us to observe their interactions with customers, both at the office and at customers' homes.

Further, officials gave us access to an unusual dataset-video and audio records of conversations between water technicians and customers at customers' houses. The dataset consisted of 11 audio and video files (5-10 minutes long), and had been recorded secretly in the previous year. We cannot confirm the socio-economic status of secretly interviewed water customers. However, the use by some of the English language indicates better education and more privilege, while complaints by others about having to spend a whole day walking long distances to distant pools, indicate less privileged customers. The dataset offered a unique opportunity to analyse genuine, disintermediated 
citizen voices in their interactions with water technicians at their homes. MUWSA officials resorted to this strategy to find out why customers were not paying water bills and to confirm whether claims ("customers do not pay us") of fee collectors were true. Collectors retain $10 \%$ of collected fees, a coveted source of extra income, and officials suspected that some kept the collected money, depriving MUWSA from a significant increase in revenue. Because this dataset was collected by the water authority without the consent of water users, we anonymized the town to protect the privacy of informants.

All interviews and citizens' conversations with water technicians were transcribed from field notes, video and audio files, and translated to English from Swahili. The transcripts were read line-by-line and free (open) codes were assigned to excerpts for analysis.

\subsection{Face-to-face interactions of customers and water officials}

We distinguish face-to-face interactions between customers and frontline officials based on where they transpire, in the office (section IVa) or in the street (section IVb) and capture the protest strategies of customers and the responses of officials.

\section{a. Encounters at the office}

A significant number of customers physically visits the offices to pay water bills and/or report water problems, which officials must record for follow-up. However, customer voices are filtered in three ways. First, not all reported complaints are recorded (as we shall illustrate later). Second, most recorded complaints are incomplete and meaningless for accountability. Columns in the register commonly left blank include: (i) date of resolving a complaint, (ii) signature of the recording officer, and (iii) remarks. Thus, either complaints are never resolved or officials neglect to update the register. Third, according to the 2012/13 MUWSA annual report, 650 customer complaints about water quality were not followed up, while during that period, technicians spent about 80 days attending only to breakdowns and leaks. Records such as "is not getting water for more than two months" and "complaining about not getting water since December [reported in March]" are omnipresent in the register. Other common records include: "Complaining about not getting water for the past two months and will pay water bill only after getting water" or "Incorrect meter reading. Not getting water since December 2013 [reported on $10^{\text {th }}$ March 2014]." Customers experience long periods without water, while information on the causes and efforts to resolve problems is missing. Apparently, MUWSA officials record complaints only to fulfil bureaucratic requirements. 
Poor record keeping hinders the identification of customers-customer names, account numbers, meter numbers and contact addresses-, the type of customers (domestic, commercial or institutional), water consumption and bill payment. Bill attendants distributing one hundred bills a day use their own memory (footpaths, local landmarks such as trees, houses of influential people in the neighbourhood) rather than the organizational memory (water distribution zones and customer details) of the water authority. Even when they can locate the house, attendants have to confirm: "Do you remember the name you registered at MUWSA?" or "What name did you register at MUWSA?" (MUWSA Bill Attendant). If the customer does not remember the name she registered at MUWSA, the water technician has to first read the meter number from the meter and try to locate it in the bills. He may have to flip through nearly 200 water bills until he can find the bill and give it to the customer. The whole process (from reading water meters to distributing water bills) may take up to 2 weeks, it involves five bill attendants (temporary staff) and two water meter readers (permanent staff), a very transaction-intensive process. When citizens report their complaints at the office, MUWSA officials respond with hostility and indifference:

Customer: "I have come to report that we do not have water for almost a week now."

Business Manager: "We do not have water either. There is a problem with the machines [inside sources stated that Electricity Company had disconnected power going to the pump house as a result of not paying bills for a long period. Consequently, MUWSA could not pump water from the lake]."

Customer: "When are we going to have water?"

Business Manager: "We are working to solve the problem. The whole town has no water. Even the district hospital where people die has no water." [Customer leaves the office. Business Manager does not record the complaint in the register]

The fear of a negative response from officials increases customers' anger: "I won't make a phone call, I am very angry with [them], I will not manage my temper and they will sue me for insulting them. By the way, I did call sometime back. I got the number of a lady official from the water vendor outside MUWSA office. I called the number and the only thing she could ask was where I got her number. [...] The lady was very angry and she said she didn't want people to get her phone number. I promised not to call her again" (Water customer). Some customers fear repercussions for "demanding too much": "I am alone, they [MUWSA staff] won't listen. They say that smart women are very troublesome. If they ask for my tribe and hear that I am a [she mentions the 
name of a vociferous tribe] they treat me with contempt. They always say that [my tribe] is stubborn because we are the only ones who complain" (Water customer).

Officials respond positively to citizens' complaints when responding generates temporary income to MUWSA as an institution or when they are likely to benefit privately. The inspection and sorting out of water bills, a lengthy and laborious work, offers a glimpse. Five officials (three bill attendants and two water meter readers) have to read more than a thousand water bills and ensure that the water consumption information printed on the bills corresponds to meter readings filled in water meter books. Officials expect to see a steady water consumption except for months with known fluctuations in the supply of water. They flag all suspect changes in the water consumption and speculate about the causes: (i) a customer selling water to neighbours ${ }^{20}$, (ii) an error in reading the water meter, iii) an error in recording the meter reading in the water meter book, or iv) an error when typing in meter readings onto a computer. When technicians cannot agree on the cause of the drastic change, they ask the business manager for advice. The first author witnessed this exchange:

Bill attendant: "This bill says the customer has used 86 units of water [1 unit $=1,000$ litres of water]. Is it possible? This is too much even if he sells water." Business Manager: "Just write the bill as it is. This is your job. Do not speak on behalf of the customer. If there is something wrong, the customer should complain."

Often MUWSA favours down-town residents to the detriment of others. A senior official, recounting past practices of fellow officials before he joined the organization, mentioned the looting of the piped water network at the outskirts of Mashujaa in favour of customers at the centre of the town: "The [water authority] depended on government grants. When these were not forthcoming the district had no money for repairs. [Officials] would [...] uproot pipes sending water to villages and use them as spare parts in down-town" (MUWSA senior official).

MUWSA officials respond to customers who can pay for repairs as shown by the response time recorded in the complaint registers. A complaint from a customer in October 2013 was resolved within two days and the "remarks" column of the complaint register read "the water pipe was broken, the customer bought spare parts and we repaired the pipe". While favouring better-off customers who can afford to pay for spare parts straight away they blame the delays to those who cannot: "We are very efficient in responding to

\footnotetext{
${ }^{20}$ MUWSA discourages its customers to sell water to their neighbours by charging them a higher water tariff compared to a normal domestic water connection.
} 
customer complaints. We are not the only ones who cause delays. You see, many problems require customers to buy spare parts and if a customer delays to buy them, the whole process will be delayed" (MUWSA Business Manager).

Officials know that most customers are unwilling to pay for poor water service. But to continue collecting water fees they use a "carrot and stick" strategy, which raises expectations for a short-lived (a few days) improvement. MUWSA gives customers 10 days deadline to pay their bills after receiving it, and sends warnings after the deadline: "We threaten to disconnect their water supply if they don't pay after a given date. If they fail to pay [...], we disconnect the service. At the same time, we give water to the nearby neighbourhood. So when they realize that their neighbours get water, they usually come to pay" (Bill Attendant). This can be understood as a form of a threat to expel customers and implies that officials do not prioritize solutions to problems facing their customers but rather ways to extract money from them irrespective of service quality.

\section{b. Encounters on the street}

A great part of the interactions, particularly with water technicians, happens outside the office. Home visits for meter reading and water bill distribution allow for different transactions to take place. For instance, customers pay their bills directly to water technicians provided they "trust" them: "Yes, I told her that she can pay if she trusts me. Because she has a debt from the past" (Water technician). In a small town like Mashujaa, water customers are often connected to officials at MUWSA or the district council as neighbours and relatives. Women married to district council officials or influential businesspeople report problems to their husbands who then contact their networks for information about the state of the water network. A female informant said: "Before we shifted to this place, one of the water technicians used to be our neighbour. He is now like a friend, so whenever there is a problem my husband calls him. For instance, he just told us that there is no water because MUWSA owes forty million to Tanesco [Tanzania Electric Supply Company Limited]" (Water customer). Customers without connections complain directly to water technicians. "We report our problems to water technicians and they should be able to pass the information to their bosses" (Water customer). In return, water technicians offer to "help" customers with problems they identify during the visits. Such problems include broken pipes, unsettled water bills and advice for purchase of spare parts.

Both audio recordings and our own fieldwork indicate that customers accuse MUWSA of ripping them off. "I sent a child twice [to MUWSA offices with money to pay the bill], and I had to pay for a motorbike [transport to and from the water authority office]. You conned us. I need to see the director for water [water authority manager]" (Water customer). Others accuse MUWSA of 
harassment, when technicians deliver to their own homes an inflated bill, or when their wives are forced to fetch water from public sources: "Just think about it. For the whole month, we only received two units [of water - a measure of water consumption, 1 unit = 1000 litres]. How do you think I survive the rest of the days? I have to buy water. I am now tired of buying water. Tell your people that we voice our opinions. Tell them that we complain about scarcity of water. Are you happy that our wives come to assemble at your office and you get to see their buttocks [when they go to collect water at MUWSA offices]" (Water customer).

While water technicians feel that their role is only to read meters and distribute water bills at the customers' homes, customers demand from them to clarify roles and responsibilities of the authority and customers:

Water customer: "You have not come to do any "service". You told me long time ago that my meter is broken. Gate valve is broken."

Water Technician: "You are supposed to buy a new one." Water customer: "Why should I buy? What about the money I pay you?"

Water Technician: "It pays the money for me coming to read a meter." Water customer: "Which meter are you talking about? You are paid for doing this work."

Water Technician: "Then I should make you read the meter and bring the reading to the office."

Water customer: "Don't worry, I am fine with that. I am close here, only those who live far cannot afford that. I think I will do a better job than you. I will give a reading on exactly $30^{\text {th }}$ [last day of the month]. What date is today? You come to read my meter on $21^{\text {st }}$, we have several days until the end of the month."

Contestations over who owns (parts of) the piped water network are common. Customers feel they own water meters because they buy them from private spare part stores. The water authority claims the opposite and cites the regulation: "When water is supplied by quantity as ascertained by water [sic], the meter shall be the property of and kept by the water authority, who is hereby authorized to charge a rent for the meter in accordance with such scale of charges as may be prescribed" (United Republic of Tanzania, 1998b) and the water contracts water customers signed when connecting to piped water supply: 
Water technician: "The service we are talking about ... the network that comes to your house. That is the service."

Water customer: "But I paid for that. I paid for the pipes connecting my house."

Customers do not refrain from cursing: "I only pay ten thousand [shillings]. But you guys... You know what... you will burn in hell. I tell you the truth. You are charging me fourteen thousands [shillings], for what? I don't have any debt. The good thing is that I reported [to the manager] that I do not have water. So what debt are you talking about? I don't owe you anything. You will burn in hell. God will burn you. You will burn!" (Water customer). The use of the English language (a language spoken by educated people) when customers talk to water technicians, and their reference to personal contacts with the manager indicate a superior social status and connection with the elite.

Another form of protest is resistance to pay bills. Almost half of the respondents refused to pay the bill until the water was flowing again: "They should come to uproot their pipes, I am fed up. I am not going to pay this bill [showing a water bill that was inside her house at the beginning of the interview. She produced it without the interviewer asking for it]. I have never had water for the past three months and they bring me this bill, for what?" (Water customer) or "Go and tell them that this time they will sue me, I am not going to pay the bill. If they sue me I am going to tell the court that MUWSA has not given me water" (Water customer).

A classic form of covert resistance, or what Scott (1985) calls the "weapons of the weak" is tampering with water meters. Tampering may be understood either as a form of voice to express dissatisfaction or a decision to first plunder and then exit the official water supply. The recorded conversations include a characteristic scene with the water technician and customer arguing about a tampered water meter: "Your meter [has] been tampered. I mean this meter has been 'de-valved' [i.e. it was reversed] and you can see it yourself. [The evidence] is the direction of water in the meter (pointing to a screen of a water meter), you see this arrow, this arrow shows the direction of water. It was supposed to show that water is flowing in the direction of the jerry can. And there is a thing too (pointing at the meter), you see that the numbers count in reverse, 9, 8, 7... usually we count numbers going forward 1, 2, 3..." (Water technician). The customer claimed that he was not aware of meter tampering but admitted to have hired a private water technician to clean the meter. $A$ common form of citizen protest is locking their gates and pretending to be at work, which makes reading water meters inside the customer's property impossible. Denial of entrance to officials frees the customer from the harassment of multiple visits. But this strategy places them on MUWSA's "radar" who have other ways to contact such customers: "We call our 
customers who have not paid their water bills or customers who lock their gates when our staff visit their houses for purposes of reading water meters or distributing water bills" (MUWSA Business Manager).

Despite various protests, some customers sympathize with front-line officials particularly the bill attendant and water technicians: "We should not blame the water technicians because they only receive orders from above. They are told to send water to this street and they cannot refuse [usually the distribution of water is done by zones, and mostly priority water customers such as hospital, district headquarters are within the same distribution pipeline]" (Water customer). Affection discourages the voicing of discontent. Further, customers who are either government employees themselves or have personal relations with officials sympathise with them and may pay just to maintain social relations.

The chronic water problems lower customers' expectations and lead to passive acceptance among some customers. Some water customers prefer an inferior service quality such as untreated water or rationed water supply instead of complete deprivation: "They [MUWSA] should give us water at least once per week. This is dry season and the sun is very hard on us. We shall use tap water for drinking and cooking. For [...] toilets, we can get water from the ponds" (Water customer). Customers are likely to welcome any fragment of service or to believe promises of improvement, although they often lose faith: "Do you think things will change if I complain? Let me tell you, our neighbour Mr. Mwendapole [not his real name] works at the water office and he doesn't have water. Every morning I see him passing here with his bag on his way to work. We feel pity for his wife, she walks long distances [to the next street] searching for water while her husband works at the water office. [I]f I was him, I wouldn't go to office. I would pretend to be sick for a month. I feel pity for him, he is very polite, and he keeps going to office even when his house has no water. So tell me if they do not care about their own people, what will make them listen to me?" (Water customer).

A significant number of customers admitted to bribing officials. They regard bribing as a coping strategy that produces straightforward, and in most cases, positive outcomes to them individually. They see their relationship with MUWSA as a private rather than collective affair: "I don't think it is possible to organize customers to voice our concerns to MUWSA. Everybody solves his or her own problem with their own means". They resort to bribing, a private "solution". Petty businessmen also resort to bribing: "It was discovered that some water technicians who were managing water rationing received bribes from people making bricks. They would release water at midnight when almost everyone is asleep, to allow brick makers to get enough water" (Water 
customer). A customer may offer a bribe to the water technician to conceal the water tampering from the authority. A video recording shows such an incident: Water customer: "Should I give you this money? [...]"

Water technician: "Yes, but the problem is that the meter has been reversed. And [...] the consumed water is not paid for. Contact me so that I can help."

A few customers do not offer bribes but rather threaten to exit MUWSA (a monopoly), which would mean buying water from informal water vendors or fetching water from unimproved sources such as shallow wells. A threat to exit symbolizes the desire for better service: "I told you that if you feel that we don't deserve the service you should stop giving us water. You don't even sympathize with us. We have been buying water since $10^{\text {th }}$ of the month" (Water customer). And: "I only got 2.4 units [of water] for the whole month. How do you expect us to live? I have a family of six people. They drink, they eat, they wash, they shower. I also have two dogs who need to drink water and food prepared for them. I have goats, they need to drink water. I have chicken who also have to drink water. Now tell me, you need me to buy water from private vendors while I have a water connection here. Is this pipe for ornamental purposes?" (Water customer).

Some customers take a longer view and express a desire for complete privatization of urban water supply (Budds \& McGranahan, 2003) similar to the privatization of telecommunications that fixed corruption: "You know what, TTCL [Tanzania Telecommunications Cooperation] played similar games. They switched telephone bills [among customers]. It caused a lot of chaos in marriages. Couples would quarrel over a call made to India. But when the company entered into a new contract [when TTCL was privatised], most of those corrupt guys lost their jobs. And now we have phones in our hands. [...] They all lost their jobs including their manager. The same will happen to the water authority. If [water is privatized] you will lose your job" (Water customer). Some customers are even willing to engage in collective protest to the water authority, but as followers, not initiators. A good number of customers acknowledged the difficulty to effectively organise collective efforts to raise voice of customers. Some feel that there should be someone else to take the initiative to organize customers to voice or take action: "I am willing to join a demonstration in case there is someone who can organize it" (Water customer).

\subsection{Discussion and conclusions}

The costly or inferior alternatives customers have to water, their individualistic relationships, and the sympathy with the officials' predicament inhibit collective action. The only form of such action we were able to observe was the significant 
shift in voter preference to the candidate of the opposition party in the presidential elections of October 2015. The town collectively blamed the ruling party for its woes, not MUWSA's management. Despite the formidable challenges they face, officials' commitment to service is substantial, as is evident from their futile efforts to digitize the billing system, the effort to understand better why revenue collection lags behind (secret surveillance operation to record the street interactions between technicians and citizens), the effort to hire a university graduate as secretary of the Customer Care Department (although she was bullied out of her job). The only hope for the authority to improve service delivery is through the new water project, which is still under construction, and the repair of the existing dilapidated and vandalised water infrastructure. But, both are likely "pipe dreams" without procurement transparency for large water construction projects and legal sanctions for vandalism (Peal, 2014).

Customers are forced to pay for a failed water infrastructure and an overstaffed bureaucracy. They are not faced with a simple organisational deterioration but with blatant injustice. They employ four main protest strategies that vary in intensity and form and are illustrated in Figure 5.2. The first, "stay and speak up", includes constructive demands to understand how officials work, to articulate needs and to appeal for fair treatment. It also includes comparison with better services, threats to demonstrate, resistance to paying water fees, accusations of rip-offs, and locking gates. The second kind, "speak up and leave", includes cursing and citizens' threats to exit the urban water system. The third kind, "resignation", involves speaking up only if visited by water technicians, willingness to follow but not lead demonstrations, reporting problems to friends connected with water technicians, bribes, tampering with water meters and a "things will not change" attitude of passive acceptance. The fourth, "leave and remain silent", includes resorting to water from inferior sources such as water ponds and a significant lowering of expectations. 
VOICE

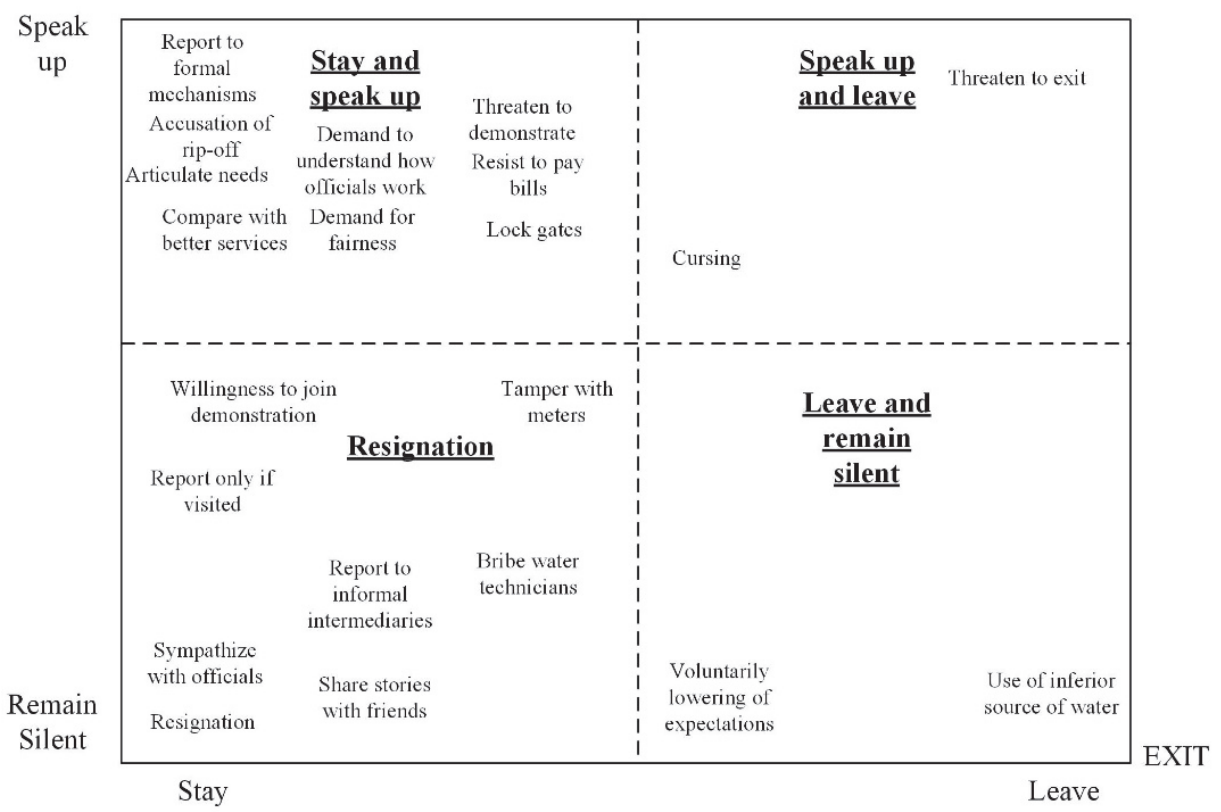

Figure 5.2: Voice and exit: protest strategies of customers to failing urban water supply

Most strategies pertain to cells "stay and speak up" and "resignation". Hardly any are in cell "speak up and leave" indicating customers' preference to stay with MUWSA despite their dissatisfaction. Given the monopolistic nature of water provision this is not surprising. Disengagement from a monopoly is costly and the stronger portion of voice in the protest-mix is understandable (Young, 1974).

Figure 5.3 summarises official responses (formal and informal) and outcomes (positive and negative) to customers. While some responses (cell 1) are labelled positive-formal (explaining the process and roles and responsibilities to customers) because they apply to all without discrimination, others (cell 4) are labelled positive-informal (respond to friends and bribers only, carrot and stick to extract payment and looting the network to benefit some and not others) because they favour friends and the better-off. Negative outcomes in cells 2 and 3 span the whole repertoire from threatening to expel the customers to secret surveillance. 


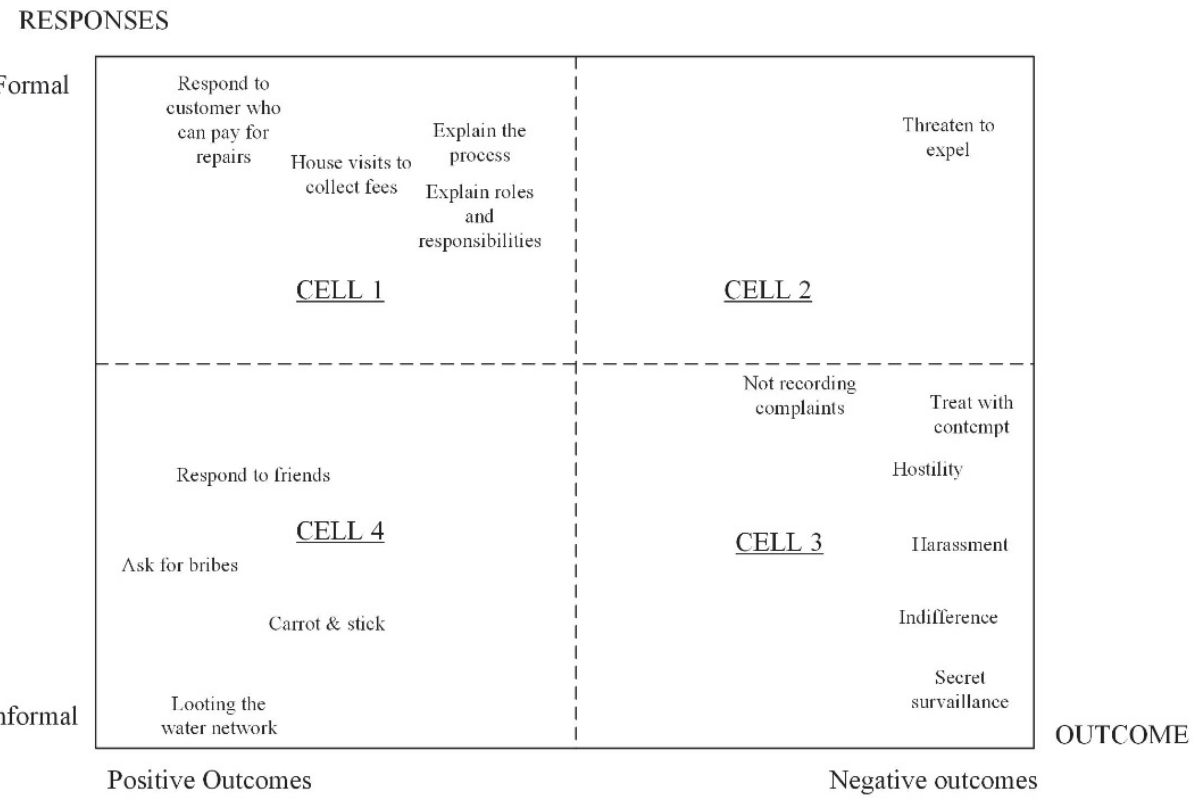

Figure 5.3: Responses of MUWSA officials to protest strategies of customers

Why do protest strategies produce a predominantly negative response by the district water authority, especially to the less privileged citizens? First, Mashujaa's piped water network is, counter-intuitively, a "differentiated" service: improvements do not benefit every customer, as one would expect from such a network. Paul (1992) argued that "when there is a scope for product differentiation in a service, externalities enjoyed by the weaker segment of the public (low voice) will tend to disappear and use of voice by the stronger segment will not improve accountability for all". The poor do not gain from the "voice" of those who can bribe or pay for repairs unless external assistance can ensure that the poor benefit as well. Second, both citizens and officials know that the service is in a dismal state-the (dismal) service is not ill-defined. There are no informational asymmetries that would make voice a preferred strategy (Young, 1974), while chronic underperformance lowers customers' expectations and increases the negativity and frustration of the water authority.

Despite the dismal state of water supply, no legal and social barriers to voice are evident in Mashujaa. Most customers, poor and better-off, seem capable of speaking up, which may be considered a form of empowerment. These results differ from Hooper and Ortolano (2012) who argued that citizens' motivation to voice is highly influenced by their economic status - house owners were more likely to participate in collective voice than renters (supposedly with lower incomes compared to house owners), because they expected higher payoffs from participation and were better connected to place. 
But, institutional barriers do exist. The design of the customer complaints register, its management and the record keeping at MUWSA are utterly inadequate to receive and follow up on complaints. MUWSA officials listen to customers, but conditionally. They value customers' voice when it serves shortterm interests of the water authority or their self-interest. This form of exclusion mirrors the findings observed in India (Chaplin, 1999, 2011) where the middle-class is perpetuating the exclusion of poor people in accessing basic urban services.

Protest strategies of citizens who are better-off (and can afford to buy spare parts or bribe) or are connected to officials (as friends, relatives or work colleagues) are successful. These results match earlier studies showing that monopolistic and rent seeking behaviours characterize small and collapsing water providers (Lovei \& Whittington, 1993). On the positive side, it is encouraging that customers "stay and speak-up." Citizens are aware of their entitlements, are willing to exercise voice and "speak truth to power", even if only in personal interactions with officials.

Face-to-face protest strategies in the "stay and speak up" cell suggest that citizens are loyal not to the water provider as an institution but to selected individuals within the organization. Such practices increase opportunities for informality, because they are 'invisible to the eyes of [the urban water authority $]^{21}$, consequently making the monitoring and achievement of SDGs more difficult. Finally, although Pastore (2015) suggests that mobile-phone based ICT platforms may be useful for formally reporting failures in public services in urban areas, we are less optimistic regarding their potential in small towns like Mashujaa, given the dominance of face-to-face interactions between customers and service providers. Mobile phones are more likely to support useful informal rather than formal interactions, a finding consistent with Chen (2016), who also warned that ICT alone cannot address pervasive systemic constraints.

\footnotetext{
21 Allen et al. (2006) argues that failure by the 'private and public sectors' [sic] to recognize and support informal water and sanitation provision makes the needs and practices of poor invisible to policy changes, consequently restricting efforts to improve access among the poor.
} 


\section{References}

Allen, A., Dávila, J. D., \& Hofmann, P. (2006). The peri-urban water poor: citizens or consumers? Environment and Urbanization, 18(2), 333-351. doi: $10.1177 / 0956247806069608$

Aubriot, J. (2014). Conflicts over water in South Africa. Inequalities, social mobilizations and the use of law. Actes De La Recherche En Sciences Sociales, 203, 136-146.

Barry, B. (1974). Review Article: 'Exit, Voice, and Loyalty'. British Journal of Political Science, 4, 79-107. doi: doi:10.1017/S0007123400009376

Budds, J., \& McGranahan, G. (2003). Are the debates on water privatization missing the point? Experiences from Africa, Asia and Latin America. Environment and Urbanization, 15(2), 87-114. doi: $10.1177 / 095624780301500222$

Chaplin, S. E. (1999). Cities, sewers and poverty: India's politics of sanitation. Environment and Urbanization, 11(1), 145-158. doi: $10.1177 / 095624789901100123$

Chaplin, S. E. (2011). Indian cities, sanitation and the state: the politics of the failure to provide. Environment and Urbanization, 23(1), 57-70. doi: 10.1177/0956247810396277

Chen, M. A. (2016). Technology, informal workers and cities: insights from Ahmedabad (India), Durban (South Africa) and Lima (Peru). Environment and Urbanization. doi: 10.1177/0956247816655986

Cheng, D. (2013). (In)visible urban water networks: the politics of nonpayment in Manila's low-income communities. Environment and Urbanization, 25(1), 249-260. doi: 10.1177/0956247812469926

EWURA. (2016). Water Utilities Performance Review Report for the Fiscal Year 2015/2016. Dar es Salaam, Tanzania: Energy and Water Utilities Regulatory Authority (EWURA).

Fung, A., Gilman, H. R., \& Shkabatur, J. (2011). Why technology hasn't revolutionized politics. Program on Liberation Technology. CDDRL, Program on Liberation Technology News. Retrieved 5th January, 2013

Furlong, K. (2010). Neoliberal Water Management: Trends, Limitations, Reformulations. Environment and Society: Advances in Research, 1(1), 46-75. doi: 10.3167/ares.2010.010103

Gwebu, T. D. (2002). Urban water scarcity management: civic vs. state response in Bulawayo. Habitat International, 26(3), 417-431. doi: http://dx.doi.org/10.1016/S0197-3975(02)00016-4

Hirschman, A. O. (1970). Exit, Voice and Loyalty: Responses to Decline in Firms, Organizations and States. Cambridge, MA: Harvard University Press.

Hooper, M., \& Ortolano, L. (2012). Motivations for slum dweller social movement participation in urban Africa: a study of mobilization in 
Kurasini, Dar es Salaam. Environment and Urbanization, 24(1), 99-114. doi: $10.1177 / 0956247811435889$

Hydén, G. (1980). Beyond Ujamaa in Tanzania: underdevelopment and an uncaptured peasantry, London. Berkerly and Los Angels: University of California Press.

Hydén, G. (1999). Top-down democratization in Tanzania. Journal of Democracy, 10(4).

Keeley, M., \& Graham, J. W. (1991). Exit, voice, and ethics. Journal of Business Ethics, 10(5), 349-355. doi: 10.1007/bf00383236

Kjellén, M. (2006). From Public Pipes to Private Hands: Water Access and Distribution in Dar Es Salaam, Tanzania (Illustrated ed.). Stockholm, Sweden: Department of Human Geography, Stockholm University.

Kombe, W. J. (2000). Regularizing housing land development during the transition to market-led supply in Tanzania. Habitat International, 24(2), 167-184. doi: http://dx.doi.org/10.1016/S0197-3975(99)00036-3

Kombe, W. J. (2005). Land use dynamics in peri-urban areas and their implications on the urban growth and form: the case of Dar es Salaam, Tanzania. Habitat International, 29(1), 113-135. doi: http://dx.doi.org/10.1016/S0197-3975(03)00076-6

Lovei, L., \& Whittington, D. (1993). Rent-extracting behavior by multiple agents in the provision of municipal water supply: A study of Jakarta, Indonesia. Water Resources Research, 29(7), 1965-1974. doi: 10.1029/92WR02998

Marson, M., \& Savin, I. (2015). Ensuring Sustainable Access to Drinking Water in Sub Saharan Africa: Conflict Between Financial and Social Objectives. World Development, 76, 26-39. doi: http://dx.doi.org/10.1016/j.worlddev.2015.06.002

Nganyanyuka, K., Martinez, J., Wesselink, A., Lungo, J. H., \& Georgiadou, Y. (2014). Accessing water services in Dar es Salaam: Are we counting what counts? Habitat International, 44, 358-366. doi: http://dx.doi.org/10.1016/j.habitatint.2014.07.003

Pastore, M. C. (2015). Reworking the relation between sanitation and the city in Dar es Salaam, Tanzania. Environment and Urbanization, 27(2), 473488. doi: $10.1177 / 0956247815592285$

Paul, S. (1991). Accountability in public services: Exit, Voice and Capture WPS 614. Washington, DC: The World Bank.

Paul, S. (1992). Accountability in public services: Exit, voice and control. World Development, 20(7), 1047-1060. doi: http://dx.doi.org/10.1016/0305$750 \times(92) 90130-\mathrm{N}$

Peal, A. (2014). Reducing vandalism of water and sanitation infrastructure: Experience from Zambia's Copperbelt. Periodic Brief. https://assets.publishing.service.gov.uk/media/57a089e6ed915d622c00 0453/TB013_ReducingVandalism.pdf 
Satterthwaite, D. (2003). The Millennium Development Goals and urban poverty reduction: great expectations and nonsense statistics. Environment and Urbanization, 15(2), 179-190. doi: $10.1177 / 095624780301500208$

Satterthwaite, D. (2016). Missing the Millennium Development Goal targets for water and sanitation in urban areas. Environment and Urbanization, 28(1), 99-118. doi: 10.1177/0956247816628435

Scott, J. C. (1985). Weapons of the Weak: Everyday Forms of Peasant Resistance. New Haven: Yale University Press.

Smiley, S. L. (2016). Water Availability and Reliability in Dar es Salaam, Tanzania. The Journal of Development Studies, 1-15. doi: 10.1080/00220388.2016.1146699

Toyama, K. (2016). Global computing: Internet and inequality. Communications of the ACM April 2016, 59(4), 28-30.

UNICEF/WHO. (2015a). Progress on Sanitation and Drinking Water: 2015 Update and MDG Assessment. Geneva: UNICEF and the World Health Organization.

United Nations. (2015). ICTs for a Sustainable World. Retrieved 19 September, 2016, from http://www.un.org/sustainabledevelopment/blog/2015/10/icts-for-asustainable-world/

United Nations. (2016). Goal 6: Ensure access to water and sanitation for all. Retrieved 19 September, 2016, from http://www.un.org/sustainabledevelopment/water-and-sanitation/

United Republic of Tanzania. (1998b). Water Works Ordinance: Chaper 281 of the Laws (Revised) Legislation and Operation Guidelines for Urban Water and Sewerage Authority. Dar es Salaam, Tanzania: Ministry of Water.

United Republic of Tanzania. (2002b). National Water Policy 2002. Dar es Salaam, Tanzania.

Venugopal, V., \& Yilmaz, S. (2010). Decentralization in Tanzania: An assessment of local government discretion and accountability. Public Administration and Development, 30(3), 215-231. doi: 10.1002/pad.556

Welle, K., Williams, J., \& Pearce, J. (2016). ICTs Help Citizens Voice Concerns over Water - Or Do They? IDS Bulletin, 47(1), 41-51. doi: http://dx.doi.org/10.19088/1968-2016.105

WHO-UNICEF. (2015). Methodological note: Proposed indicator framework for monitoring SDG targets on drinking water, sanitation, hygiene and wastewater.

World Bank. (2003). World Development Report 2004: Making Services Work for the Poor. Washington, D.C.: World Bank \& Oxford University Press.

World Bank. (2016). World Development Report 2016: Digital Dividends. NewYork, USA: The World Bank.

Young, D. R. (1974). Exit and voice in the organization of public services. Social Science Information, 13(3), 49-65. doi: 10.1177/053901847401300303 
Chapter 6

Formality and informality in rural water supply in Tanzania 


\begin{abstract}
In Tanzania, the formal institutional framework for rural water supply is difficult to implement while informality dominates the sector. This is problematic when information and communication technologies (ICTs), carrying their own normative imprint, are introduced to improve rural water services for citizens. Our premise is that successful implementation of ICTs, such as mobile-phone based platforms for updating rural water point data, rely on understanding the (in)formal structures in which they are supposed to be embedded. Our aim is to understand how actors in rural water supply-ordinary citizens, Community Owned Water Supply Organizations, elected councillors and district officialsperceive their own formal responsibilities and those of others, how they informally relate to each other and how ICT may improve these relations. We analysed a variety of qualitative data collected from February to March 2015 in Mashujaa, one of the poorest districts in Tanzania. We show that these actors are aware of their own formal responsibilities and those of others, as well as of the formal channels through which to communicate. We find evidence of informality that either improves or does not improve rural water services for citizens. The only informality that is useful to citizens is practiced by citizens themselves. ICT may help actors increase their capacity to perform their roles and reduce useless information-intensive informality, in particular if it is framed as a transparent tool shared by all actors.
\end{abstract}

\title{
6.1 Introduction
}

Sustaining a functional rural water supply infrastructure has been a challenge in sub-Saharan Africa (Giné \& Pérez-Foguet, 2008). In Tanzania, nearly half of rural water points are not functional (United republic of Tanzania, 2013c) and about $20 \%$ of newly constructed water points become non-functional within one year (Welle \& Williams, 2014). Currently, around 70 per cent of 44 million Tanzanians live in rural areas, while population increases by 1.2 million people every year, one of the fastest growth rates in the world (UNDP, 2014). What is more, an increasing number of Tanzanians in rural areas are compelled to resort to traditional, unimproved water sources (ponds and streams), thereby endangering their health and well-being (UNICEF/WHO, 2015a).

In response to this long-lasting problem, the Government of Tanzania radically changed in the past 15 years the formal institutional framework of rural water supply, first through the National Water Policy (NAWAPO 2002) and later through the Water Sector Development Program (WSDP) (2006-2025). Under NAWAPO, "consultations and planning start from the grass roots; implementation is at the most appropriate level, closest to the beneficiaries. User groups are not only responsible for operating, maintaining and sustaining the infrastructure; they are also responsible for planning and managing it for the entire water sector in Tanzania" (United Republic of Tanzania, 2006, p. 3). 
The Water Supply and Sanitation Act was enacted in 2009 to provide, among other things, for the establishment and registration of Community Owned Water Supply Organizations (COWSOs), a new village institution (United Republic of Tanzania, 2002b). The WSDP consolidated for the first time three sub-sector programmes-water resources management, rural water supply, urban water supply and sewerage-and is implemented in two phases: the first phase (2007-2014) attracted donor funding of the order of US $\$ 1$.3billion, while the second (2015-2025) is budgeted with US\$3billion.

Because the WSDP is donor-funded, it requires upwards accountability for the disbursement of donor funds all the way up from the district to the national level and the donors. This contradicts the policy rhetoric of decentralisation from the central to lower tiers of government and fuels power struggles between district and central government and between the district government and village COWSOs. COWSOs should bear the full cost of Operation \& Maintenance (O\&M) of rural water schemes. But, in practice communities either refuse or cannot afford to contribute and COWSOs resort to the district for assistance. But, as (Tilley, 2013) argues "district staff are left to sort things out by themselves, with some persisting and others giving up" (p. 8), while communities "limp along" from one water point breakdown to the next (Chowns, 2015, p. 273).

An integral part of the WSDP is the Water Point Mapping System (WPMS), an innovative web-based information system developed and implemented in the period 2010-2013 by the Ministry of Water and Irrigation (MoWI). The WPMS provides in digital form the status of all rural water points and aims to monitor the performance of actors-do they act responsibly?-at different levels of government. Currently, the WPMS is not being used as planned, while setting up a cost-effective updating mechanism for rural water point data remains a significant challenge. In the past three years, the SEMA ${ }^{22}$ research team has attempted to tackle the updating challenge and developed a mobile phonebased updating mechanism, the SEMA app, which comprises an Unstructured Supplementary Service Data (USSD) client for standard mobile phones, and an Android client for smart mobile phones. Either ordinary villagers or those with an official status in village communities (e.g. Village Executive Officers and COWSO leaders) may use the SEMA app on their standard mobile phones to report water point breakdowns to local government: "Is this water point functional, not-functional, needing repair?" We used the SEMA app as a research tool that enabled us to collect data on the reporting behaviour of cowso leaders, as well as on the responsiveness of water officials to the reports, in various meetings and workshops.

22 Sensors, Empowerment and Accountability in Tanzania (SEMA), NWO-Wotro integrated research project 
Researchers and practitioners are sceptical about the potential of such apps to transform rural water services in Tanzania and have attempted to explain why they usually fail (see e.g. Welle et al. (2016). Some attribute the failure to the apathy and lack of agency of rural citizens (Taylor, 2011b), or to ignorance of their formal roles responsibilities (SNV, 2010). This study, in one of the poorest districts of Tanzania, suggests otherwise. Rural water supply actors are quite knowledgeable of their formal responsibilities but often channel their agency in informal ways to improve water services, as other studies in the Tanzanian context have shown (Kjellén, 2000; Kjellén \& McGranahan, 2006; Nganyanyuka et al., 2014). And, these (in)formal structures in which ICT will be embedded must be revealed before new information and communication technologies (ICT) are designed and implemented (Fung et al., 2013).

This paper complements earlier research analytically and empirically. Analytically, we take a systems approach (Kühl, 2013) to distinguish between formal and informal structures within rural water supply and to assess (in)formality in terms of its usefulness to rural citizens. We do not consider informality as a constraint to the implementation and use of ICT but as structures that grow in the interstices of the formal system as a useful reaction to, and in avoidance of, formal rigidity (Holzer, 2014). Empirically, we analyse qualitative data collected in Mashujaa district with local councillors, COWSOs, and district officials and rural citizens, the ultimate (but chronically bypassed) beneficiaries of rural water services (Booth, 2015; Therkildsen, 1988). The research question is "how do citizens, COWSOs, councillors and district officials perceive their own responsibilities and those of other actors and to what extent can a mobile phone-based platform improve rural water services?"

\subsection{Empirical context}

In this section, we describe the formal responsibilities of district officials, elected councillors, COWSOs and citizens, as stipulated in national legislation and government guidelines. But first, a brief overview of Mashujaa district, our fieldwork site, is in order. Mashujaa, anonymized here, is one of the poorest districts in Tanzania. More than half of its 300,000 people live below the poverty line. Almost $80 \%$ are engaged in subsistence farming and livestock keeping while the rest practices petty trading and small-scale fishing in the nearby lake. Ubiquitous Chinese motorcycles ensure transportation to remote areas. Mobile phone connectivity is fairly good at the district capital but variable in the villages. The main sources of water are shallow wells and boreholes fitted with hand pumps or motorized pumps powered by diesel or electricity. Most of the rural water infrastructure is now crumbling due to old age and lack of maintenance, while $69 \%$ of the shallow wells and $55 \%$ of the hand pumps are non-functional. The four (also anonymized) village communities, Mji Mwema, Mwembeni, Mtakuja and Ufukweni, which we studied in detail, are coping with 
a 28-40 years old infrastructure and water extraction and distribution technologies of varying complexity.

During the 1970s and early 1980s, the government provided free water largely through hand pumps. Between 1985 and 2000, the district government received financial assistance from Scandinavian countries to construct shallow and deep wells and introduced village bank accounts for water funds. Improvements were short-lived as many wells became non-functional after a short period of operation. District officials attribute the failure to extreme drought caused by climate change, lack of community ownership, and vandalism of water pumps and pipes by community members due to "poverty and ignorance" (interview with district water technician). Mashujaa district elects two Members of Parliament - each serving two of the four selected villages. During fieldwork, one of them was Minister and was known to have successfully channelled resources for water projects to his own constituency.

District officials: According to section 38 of the National Water and Sanitation Act (2009), officials at the district council, such as District Water Engineers (DWEs) and District Community Development Officers (DCDOs), have two main responsibilities. First, they must facilitate and advise on the process to register a COWSO, including the election of COWSO leaders. Thereafter they must monitor them and submit quarterly reports to the Ministry of Water and Irrigation (MoWI) and to the President's Office Regional Administration and Local Government (PO-RALG) on the status and progress of COWSO registration. Second, district officials must follow-up on the operation and maintenance of old water projects and submit quarterly reports to MoWI and PO-RALG on the progress of new water projects in the district.

Councillors: Ward councillors are members of the district council and are elected every five years. They represent to the district council the interests of citizens in their ward-an administrative area made up by two or more villages within a district. To collect information about the state of affairs within their ward, councillors must organize ward meetings to listen to citizens' suggestions (United Republic of Tanzania, 2010). Further, they must oversee the district council on behalf of the citizens in three ways: they must (i) seek information on the plans, budgets and performance of the district, (ii) question the district on the planning (allocation of resources) or implementation of district plans and budgets, and (iii) participate in sanctioning poorly performing district staff. Councillors have the power to hire and fire district officials and thus can influence the performance of the latter. In practice, councillors' sanctioning ability is limited.

"Councillors can do nothing to discipline heads of departments as they are not recruited by them. The only thing they can do is to air their 
voices against non-performing or corrupt officials. But the final decision is made by the central government which may decide to transfer them to other councils rather than firing them" (Braathen et al., 2005, p. 10).

CowSOs: COWSOs are responsible for the operation and management of water projects in the villages. In principle, COWSO members operate and maintain water projects as volunteers, without payment. A COWSO works closely with the Ward Executive Officer (WEO) and Village Executive Officer (VEO) to ensure that the installed water projects are properly operated and maintained (by trained pump attendants) and that users (villagers) establish and maintain water funds and pay full operation and maintenance costs. Theoretically, COWSOs are required to report to the District Water Engineer (DWE) on a quarterly basis (United Republic of Tanzania, 2009) particularly when they receive financial assistance (grants or loans) from the district council. In practice, COWSOs report to DWEs only when water points break down. Most current COWSO members used to manage village water committees-the old institutions that COWSOs are now gradually replacing. Thus, in many villages of Mashujaa traditional water committees still exist either as the main providers of water services in many villages (e.g. in Ufukweni) or in parallel with the newly formed COWSOs (e.g. Mwembeni).

Citizens: Citizens must contribute a portion of the capital investment to demonstrate their commitment to rural water projects in their villages. They must participate in the design and planning of rural water projects including the choice of affordable and suitable technology (United Republic of Tanzania, 2002b) and demonstrate their ability to pay for operation and maintenance. In addition, citizens may attract government grants for a water project by influencing ward councillors, their elected representatives.

\subsection{Conceptual approach and methods}

To conceptualise formality and informality in rural water supply, we use the systems approach to organisational studies (Kühl, 2013). At the heart of this approach is the concept of organisational structures. These are decisions that serve as premises upon which other decisions are routinely made within an organization. For example, the decision of a water engineer to repair a water pump in a village does not qualify as a decision premise, because it applies only to this particular water pump. However, when the Ministry of Water decides that the district water engineer must repair any broken water pump in his district within ten days of the break down, a decision premise comes into play. 
Organisational structures are either formally decided (formal structures) or informally "decided" (informal structures). Any organisation, however complex, has three types of (in)formal structures-programs, communication channels and members. Programs determine which actions in the organization are to be viewed as right, and which as wrong. Communication channels define how information must be communicated within the organization and the pathways it must follow. For members the underlying consideration is that the type of individual placed in a given position will make a difference for future decisions within the organisation.

\subsubsection{Formal and informal organisational structures}

Programs constitute the first organisational structure. In rural water supply, formal programs include legislative acts, policies, and information systems (e.g. the Water Point Mapping System mentioned earlier). They determine which formal responsibilities organisational members have and, consequently, which of their actions are to be viewed as right or wrong, and rewarded or sanctioned, respectively. The National Water Policy (2002) and related legislative acts (United Republic of Tanzania, 1982, 1998a, 2009) determine the responsibilities of district officials, councillors and COWSOs in rural water supply. For instance, district officials must provide information on the status of water services in the district. Councillors must access district public records and raise questions in water-related council meetings. COWSOs must follow up on non-functional water points and mobilize communities for their revival. Informal programs may take the form of well-established, customary routines and dictate informal responsibilities such as citizens expecting councillors to contribute their personal funds for water projects.

Communication channels are the second organisational structure. Formal communication channels include the rules and procedures and information flows among organisational members. Communication channels are the only means of preventing communications overkill (everybody communicating with everybody else) within an organization. Chapter 7 describes in minute detail the formal and informal rules and procedures governing the information flow between a village COWSO and the district council when a rural water pump breaks down. Informal communication channels develop when formal hierarchies are routinely bypassed, or when informal hierarchies are set up based on political party or tribal affiliations. Examples are COWSO leaders bypassing the village assembly, and instead reporting their performance to leaders of civic associations during village feasts or citizens contacting political figures or central government public officials (not necessarily involved in the water sector) to pressure district officials to respond to their needs.

Members constitute the third organisational structure, because decisions that affect the organization always depend on who occupies the position responsible 
for making them (Kühl, 2013). A COWSO or village leader who belongs to the ruling political party may decide differently on rural water supply from a leader who leans towards the opposition party. In the late 1960s, when Julius Nyerere massively resettled peasants to newly formed villages, peasants often chose petty-capitalist farmers as village leaders "on the assumption that they were better equipped to deal with officials, including protecting them from government interventions that would threaten their livelihood. In places where there were no such petty-capitalists, villagers often chose individuals known not to be interested in change" ((Hydén, 1980, p. 114), emphasis in original), but people whose interest in interfering with their life was small. Informal members in rural water supply are institutions outside the formal rural water hierarchy and include the Church, Islamic institutions, or grassroots civic associations.

Informality may be either compatible with formality, or it may break the formal rules and procedures (but still be useful) or it may break the law. The systems approach to the study of organisations teaches that informality cannot be suppressed by decree; it can take different, perhaps more desirable forms only when changes are made to the formal structures themselves. For instance, in September 2015, the Ministry of Water and Irrigation introduced a new program to revamp the updating mechanism of the Water Point Mapping System and created new roles and responsibilities for Ministry officials (United Republic of Tanzania, 2015a). This change of formal rules and procedures will not supress informality. Instead it may lead to new informal structures that are more conducive to improvement of rural water services at the district and village levels.

\subsubsection{Methods}

We analysed three qualitative datasets from fieldwork conducted between February and March 2015 in Mashujaa district. The first dataset includes discussions at a workshop (SEMA app workshop). The second dataset draws on focus group discussions with citizens in four villages: Mji Mwema, Mwembeni, Mtakuja and Ufukweni while the third includes informal interviews and participant observation. To preserve the anonymity of informants, we use fictitious names for the district and the villages.

SEMA app workshop: The workshop was conducted in the last week of February 2015 at Mashujaa's district council. It brought together our research team, councillors, district officials and COWSO leaders from the four selected villages. The purpose was to present the SEMA mobile phone-based platform (SEMA app) to the participants and receive their feedback on its usefulness. We asked the participants which type of information is useful to them for fulfilling their responsibilities and who they considered as appropriate providers of information on the functionality of water points at the village level. The 
workshop brought together the SEMA team and 20 participants: councillors, district water experts, representatives of four community owned water supply organizations, and senior District Council staff from the ICT and planning departments.

Focus group discussions: Immediately after the workshop, the first author organised and conducted eight focus group discussions in the four villages, during March 2016. The aim was to acquire a deeper understanding of citizens' perceptions of their responsibilities and those of COWSOs, councillors and district officials. The Village Executive Officer (VEO), accompanied by the first author, selected and invited citizens by mobile phone or home visits in each village. We reimbursed the VEOs for the calls they made. We recruited eight groups (two groups in each village) of ten people for meetings of about two hours. All invitees showed up and were separated in two groups, the young and the old. Their ages ranged from 19 to 60 years. Most came to the venue by walking. Those who came by motorbikes were reimbursed for the cost of transport. Each group featured both genders and a mix of peasants, livestock keepers, petty traders, and retirees, e.g., retired soldiers and teachers. Including labourers proved difficult:

"In this area a labourer is someone who works for someone else on subsistence basis. [...] you will never find anyone who identifies himself as a labourer. Working for someone else is considered to being inferior. People here would rather beg than work as a labourer. When I work as a labourer, I am submitting myself to the master [the employer]. We have pride in our culture and we do not want to be seen working for anyone" (Water Technician, Ufukweni).

We paid each participant Tsh5000 (US\$2.5) as compensation at the end of each focus group session. We had planned this incentive but failed to mention it in the invitation. Before the start of each session, participants in all four villages inquired whether they would be paid for participating but referred to the fee, with different terms: "empowerment" in Mwembeni, "facilitation" in Mji Mwema, "freedom" in Ufukweni, and "allowance" in Mtakuja. While the variety of terms used is surprising, the citizens' demand to be paid cash for participatory activities illustrates their pragmatism and their desire for symmetry with us, the discussion organisers, who are also paid to conduct this work. Being paid cash for "participating" is common practice in development interventions in rural Tanzania. And a cash payment is preferable to a meal consumed by a single member of a household during the discussion because it can benefit her entire household. Each focus group discussion started with a speech by the VEO introducing the researcher, who then explained the objective of the session. Soon after, the VEOs left and the researcher informed 
the participants that they could drop out at any time if they felt like it, without affecting their eligibility for cash compensation. But none dropped out.

Informal interviews and participant observation: My long stay in the research area made me a familiar and trusted figure in the villages. I was able to have numerous formal and informal interactions with district officials, COWSO leaders, village leaders, politicians and common citizens. I was allowed to accompany district officials handing over COWSO certificates in nineteen villages. This helped me to create relationships with focus group participants and to raise pertinent discussion points during the sessions. Participant observation led to a better appreciation of village life and local power relations. Informal interactions with informants in the market, in canteens and on the street revealed socio-cultural aspects that interviews alone cannot capture (Iacono et al., 2009). I conducted almost all interviews in Kiswahili, transcribed these and the field notes, translated into English, and coded and analysed them.

\subsection{Perceptions of actors on their own responsibilities and those of others in improving rural water supply}

This section presents perceptions of members regarding their own responsibilities and those of others in improving rural water supply.

\subsubsection{How COWSOs, councillors and district officials view their responsibilities}

How Cowsos see themselves: COWSO leaders perceive themselves as orphans, without proper guidance from the district. On one hand, they blame the district for not preparing them well to carry out their new responsibilities: "We were given a COWSO certificate but we were not trained. We need to know our boundaries. We are like ducklings [as opposed to chicken, ducklings walk in front of the duck and lead the way while the duck follows]. Education is a very important thing. The district council gave us the [COWSO] certificate, but no education" (COWSO leader in Mwembeni). On the other hand, they feel responsible only to citizens with house connections who can afford to pay their water fees:

"Last week there was a funeral in the village and there was no water. People had to walk with their buckets on their heads from the dam. When people realized that the COWSO chairperson was present at the funeral, they asked him to explain why we don't have water. Surprisingly, he responded that he is only answerable to people who have house water connections. Actually that was just an excuse, why 
should he say that he is only answerable to people with house water connections when all citizens contributed to the water project?" (Citizen, Mwembeni).

The chairperson's limited answerability only to paying customers in the village can be seen as a coping strategy that allows her to at least tackle effectively a part of her responsibilities, in the absence of support from the district.

How councillors see themselves: Councillors own up to their formal responsibilities in rural water supply and are confident of their capacity to act: "If we play like one team, let's say I am council chairperson and I advise the [District Executive Director] DED to instruct professionals from the water, health, agriculture departments to come up with rigorous plans [...] we can definitely move forward" (Councillor, Mwembeni). Councillors see the SEMA app as an instrument that "eases follow-ups" (Councillor, Mtakuja) in their constituencies or "pressures us to visit areas with problems" (Councillor, Mwembeni). Yet, they were sceptical about the competence of their fellow councillors: "I tell you most councillors including the council chairperson lack education or do have education but lack knowledge on their oversight roles. I tell you at the end of the day nothing moves forward" (Councillor, Mwembeni). Sneering at the educational level of their peers may be due to the fierce competition among them in the presidential election campaign that was in full swing during fieldwork.

Councillors readily admit that they find themselves between a rock and a hard place in the exercise of their oversight responsibilities. This is because shaming the district council shames the ruling party to which they themselves belong. The dilemma is usually solved behind closed doors. During largely ceremonial council meetings, which are open to the public, the ruling party restrains its councillors from asking embarrassing questions to district officials. Instead councillors of the ruling party conduct closed meetings prior to each council meeting, where district officials (including the DED) can respond to critiques of their performance. Often, councillors whose private firms procure services to the district council are in a conflict of interest situation. Since the district council is the main source of income for their firms, they often choose to be lenient in their oversight role with the expectation to receive contracts from the district: "It is like barter trade. You [district official] give me [councillor] a tender to construct a road, or water well; and in return I will not object your health/water/infrastructure budget when you table it before the council meeting" (Councillor, Mwembeni).

How district officials see themselves: District officials are well aware of their obligation to know the state of rural water supply in the district and of the value of information they must collect in order to be able to regularly report 
upwards to the District Commissioner and Regional Commissioner, to the Ministry of Water and Irrigation (MoWI) and to the ruling party, especially before national elections. But, they are overburdened by the different formats and the excessive reporting, and consider it detrimental to their day-to-day work. District officials see the SEMA app as a tool that can "get up-to-date and correct data across all departments in the district" but insisted that only "the planning office [department] which is coordinating all planning activities and statistics of the district should be involved" (Senior district official, Mashujaa). While acting under enormous pressure from hierarchical superiors, donors' funding patterns oblige them to collect information on the implementation of new projects instead of repairing existing ones: "We will renovate the dysfunctional water points as soon as money becomes available. Right now the available budget from donors focuses on new water projects" (District official, Mashujaa). As a result, they are forced to give lower priority to technical and financial assistance, downwards, to cowsOs.

\subsubsection{How COWSOs, Councillors and District Officials view each other's responsibilities}

How cowsOs view councillors and vice versa: The nature of the relationship between COWSOs and ward councillors did not emerge vividly from the data, suggesting that COWSOs do not perceive local councillors as influential in improving access to water and vice versa local councillors do not appreciate the importance of COWSOs. However, COWSO leaders repeatedly referred to Members of Parliament (MPs) and national government leaders (particularly the President and Prime Minister) as powerful agents in rural water supply.

How COWSOs view district officials and vice versa: Local leaders are under pressure from district officials to mobilize citizens to register COWSOs, a process that requires a formal citizen general assembly, with written minutes and list of all attendees. COWSO leaders find it difficult to mobilize citizens, who are selective in attending meetings. Thus, leaders often fake the list of attendees of previous meetings, e.g. for food distribution, which commonly attract large audiences:

"It was difficult to get a quorum [for the COWSO registration meeting]; we tried several times to postpone and reschedule the meeting. Reasons for low attendance kept changing, if this week it was a funeral, the next week it was something else. I had no means, the district council kept pressing for the list. I had to use a list of villagers who attended a previous general assembly which discussed the distribution of hunger relief food" (COWSO leader, Mwembeni). 
COWSO members complain that district officials are more interested in benefiting personally rather than helping them in technical aspects of rural water supply: "The district should only be involved in non-monetary issues. We know that the district has the technical know-how [...], we cannot avoid that. But the district should be avoided for all issues related to transactions of funds, otherwise they will find ways to get a share of the funds [for personal benefits]. We have seen it with other funds [...] All they do is eat our money" (COWSO member, Mwembeni).

Budget and information opacity are major sources of tension. COWSO leaders demand transparency regarding the district grants allocated to COWSOs: "The [COWSO] grant is like rainfall, if it rains that's ok, if it doesn't, then we just keep waiting, you can never can tell when [the grant] will come" (COWSO leader, Ufukweni). District officials' opacity is evident in their selective use of the English language, instead of Kiswahili, when discussing construction problems of water pumps for which they are accountable:

"When they came to inspect our pump they found some things were not right, but they did not want us to know. The engineers were conversing in English thinking that I could not understand them. I am an English teacher, I teach secondary school students so I got all they said very clearly. They found that the pump and the mortar did not match; the pump is stronger than the mortar. With such a combination, we always have problems with our water project." (COWSO member, Mwembeni).

District officials, the custodians of rural water supply at the district level, expect COWSOs to submit quarterly performance reports including income and expenditures. In practice, the district water engineer demands these reports only from COWSOs with piped water schemes. Two of the four cases in this study have piped schemes and thus have been reporting regularly to the district council. The other two have hand pumps and do not report regularly unless there is a problem.

How councillors view district officials and vice versa: District officials appear opaque towards councillors as well. The latter complain that district officials do not provide them with enough time to scrutinize budgets and plans: "I am a member of the Education, Health and Water Committee [...] They ask us to sit for one day in council meetings [...] the entire district has 106 villages, 158 primary schools, 29 secondary schools, 42 health centres, 3 hospitals, 400 water wells. How can you effectively discuss all these sectors in a one day meeting? Your head must be a machine to understand what is going on in all areas" (Councillor, Mwembeni ward). 
On the other hand, district officials are weary of both councillors and MPs, interfering with the allocation of resources for new water projects:

"The selection of [name of a village] water project was very political. We tried to refuse it but there was an order from an [MP] to include it. The project is now complete but citizens refuse to contribute. The project cost eight hundred million Tanzanian Shillings and the villagers were required to contribute $5 \%$ which is equivalent to about forty million. The MP contributed only two million shillings from the constituency development fund ${ }^{23}$. The contractor wanted to hire villagers so that he could pay their contribution on their behalf. The villagers refused on the pretext that the MP promised them free water. Currently, the villagers get water but I am afraid it won't last long" (District water official, Mashujaa).

Politicians' promises to provide free water to citizens are against national water policy and undermine efforts of district officials to make citizens take full responsibility for the operation and maintenance of rural water projects. Further, district officials consider councillors' interest in new and expanded water projects as detrimental to the repair of old ones: "Many councillors want to see new water projects allocated to their wards. When existing projects are too old, councillors want to see them expanded" (District water official, Mashujaa). The excessive eagerness of councillors to please the voters works against the public interest: "A community may want a bore hole but the councillor may want to please a certain group of people who voted for him and if this group wants a water trough for livestock, then the councillor will fight for a water trough instead of a project that was prioritized by majority" (District water official, Mashujaa).

Last but not least, district officials are sensitive to attacks on their professionalism, especially in open meetings attended by citizens, and apparently "cook" the numbers. For example, while preparing a progress report on the implementation of a water project, district officials had to estimate the progress as a percentage of the completed work: "This number [a figure in the report representing the status of the construction of a water project] may get us in trouble with the councillors, besides [the contractor] has not done anything since we paid him; let's reduce the number from 30\% to $10 \%$ completion. We should not let politicians humiliate us and question our professional conduct unnecessarily" (District water official, Mashujaa).

23 In Tanzania, parliamentarians receive one million shillings every month to support developmental activities in their constituencies. 


\subsubsection{How citizens view their responsibilities and those of others}

How citizens view CowsOs and vice versa: Citizens are aware that they must contribute money and/or labour to water projects. And when COWSO plans for water projects do not align with their interests they are capable of collective action. In Ufukweni, a village with chronically poor water supply, citizens gave an ultimatum to their COWSO: they would contribute money only after an uninterrupted water supply for at least three months. Citizens are not convinced that COWSOs can provide adequate safe and clean water due to political interference and corruption: "The problem is infrastructure and poor management. Poor management is caused by politics and personal gains" (Citizen, Mwembeni).

cowso leaders set up meetings only when they need to collect contributions from citizens: "We mostly get invited when they want us to contribute money for a project and usually there is no room to negotiate" (Citizen, Mwembeni). Citizens are well aware of the technical problems facing COWSOs: "We have water pipes but most of them are like sculptures. They are there but they do not provide water" (Citizen, Ufukweni). But even if all existing water infrastructure were functional, a large part of the population would still be without reliable access to safe and clean water: "Even if the water project was functional, it cannot serve the whole population. A large part of the population does not have access to water from the project" (Citizen, Ufukweni). COWSOs feel that they have failed citizens as the Mwembeni COWSO secretary narrates: "many citizens are mad at me because they think I have failed them, they expected more from me than what I have done. But I have told them, my hands are tied up, the solution for water in this village is beyond my capacity, the district council has to solve this problem" (COWSO secretary, Mwembeni).

How citizens view councillors and vice versa: Citizens are sceptical about the effectiveness of councillors but are pragmatic enough to accept that councillors are vulnerable to bribes from district officials because they often lack a steady source of income:

"It is not that councillors do not know what they are supposed to do, it is more about survival. You wonder why councillors spend most of their time at district offices. What are they doing there all that time? In the end, they get too close to officials. As a result, it is difficult for them to scrutinize the officials' work" (Citizen, Mwembeni).

With respect to the role of MPs in getting funds for new water projects, citizens are more positive: "I was informed by the MP, that he has made some efforts to include us in the project" (Citizen, Mwembeni). On the other hand, councillors are full of praise for citizens' capacity to mobilize if the district has no funds: "If $[\ldots]$ there are no district funds for repairs, the pressure to mobilize 
citizens to contribute money is higher. In Sazira for instance, it was very easy to mobilize citizens to contribute a thousand shillings [per person] to repair a water point" (Councillor, Mtakuja).

How citizens view district officials and vice versa: The common sentiment among citizens is that district officials only work when pressured by central government, especially when central government leaders physically visit the villages: "If we don't get visitors from Dar es Salaam (central government), then we shall never see flowing water" (Citizen, Mtakuja). Citizens are left out of decisions regarding the planning and designing of rural water projects: "If you are a good observer, if you are good with psychology, you must have noted that we have problems. Those who attended the handing over meeting [of COWSO certificate] did not represent the ward, because the ward is very big [consequently a large number of citizens]. Most people who attended the meeting were invited while the meeting had already started. So when people see such things they just stay quiet. If people were informed about the project and prepared, you would have seen many more singing songs of praise and joy. That is why we still face the problems of water, and I think the district council [handed over the certificate] just because they were pressurized" (Citizen, Mwembeni).

Citizens are often not aware of the bylaws in COWSO constitutions, and when they are, they often contest them. In one of the general assemblies for handing over a COWSO certificate citizens questioned the rationale of a bylaw that prohibits wearing shoes at a water source: "This is colonialism [oppression], how do you ban shoes at water sources, how do citizens benefit from this ban?" (Citizen, Mwembeni). Citizens attribute their low participation in public meetings (where a cowsO constitution is reviewed and approved) to exclusionary practices of district officials: "The preparation of this meeting is poor; we normally conduct our meetings with loudspeakers so that everyone can hear what is discussed. Not today." (Citizen, Mwembeni) and to pressures applied to district officials from higher levels of the government.

According to citizens, district officials not only receive bribes from unqualified contractors to award them water projects, they also buy out villagers: "Corruption is very evident and impedes all efforts to fight for our rights. If we send one of the villagers to the regional commissioner, the district council [district officials] may bribe him and when he returns he will not say anything about the issue" (Citizen, Mwembeni). Moreover, district officials are supposed to at least get a share of the funds allocated to finance the construction and maintenance of rural water projects: "Within our district council, when funds are allocated to a village, the (District Executive Director] DED will get his share, the district commissioner will get his share, the council chairperson will 
cut his share. In the end, the village receives only a small part of the fund" (Citizen, Mwembeni).

District officials constantly emphasize the responsibilities of citizens in improving rural water supply by appealing to NAWAPO (2002) and the National Water Supply and Sanitation Act (2009). For them "full citizen responsibility" includes: First, citizens must initiate the process by prioritizing water projects and demonstrate demand by showing the ability to pay part of the costs (usually measured by their ability to contribute money and opening up bank accounts). District officials expect citizens to include water projects in their annual village plans and budgets. Second, citizens must contribute (either in cash or in kind) part of the capital investment for the construction of rural water projects. The actual amount of the contribution may change depending on factors such as total cost of the project, population of the village and economic level of the citizens. In Mwembeni, for instance, citizens were required to contribute $5 \%$ of capital investment, however, district officials lowered it to $2.5 \%$ after realizing that citizens could not afford the original rate. Third, citizens must participate in the implementation of rural water projects to ensure that contractors deliver in accordance to value for money. Fourth, citizens are required to participate in the operation and maintenance of rural water projects. As such they are required to pay fees for the water they receive so that the funds can be used to finance the day-to-day operation, repairs and expansion of water projects.

District officials attribute citizens' resistance to pay because do not see the added value of water from improved sources as compared to water from unimproved sources: "Citizens may be right as we don't add anything to the water apart from pumping to a tank and distribute it through pipes. We don't treat the water, so the only difference is that it comes from taps [as opposed to unimproved source such as a shallow well, river or lake]" (District water official, Mashujaa).

How citizens view themselves: Citizens are aware that they are responsible for improving water services in their localities. They know they must contribute capital to the construction of new water projects and take full responsibility in operation and maintenance of rural water projects, usually translated as their willingness to pay for water. They also know that they must oversee service providers such as village water committees, COWSOs and district council. This awareness is probably the result of countless efforts by the district council to enlighten citizens to take full responsibility in the planning, design, operation and maintenance of rural water projects. Often, however, citizens' awareness and willingness to contribute is due to feelings of shame about the poor state of water supply in their villages especially when compared to experiences of their relatives in major urban areas. "It is the norm here for parents to call 
their educated children in urban centres to get their opinion on whatever happens in the village" (COWSO leader, Mtakuja).

Conscious of the challenges to improve water services through the government, citizens embark upon collective efforts to improving rural water supply on their own and without government interference, as the example of the Elderly-men for Development Association (Wazee wa Maendeleo wa Mwembeni - EDAM) shows. EDAM is a civic association, registered in 2000, dealing with matters of public interest in Mwembeni ward and acts as a collective voice of villagers:

"The association started as a group of people to represent the village [currently divided into four villages to form a ward] when visited by higher level government leaders. For instance, when the President [of Tanzania] visits the village, we thought we should have a group of people who would have more personal and face-to-face meetings with him to present interests and problems of the village. This is how the elderly association began. However, this is not the first time we have an elderly association. We had a very successful association of elders during Ujamaa which had a petrol station and a passenger bus" (Citizen, Mwembeni).

EDAM's originator was Jacob (not his real name), a successful businessman living in nearby major urban centre about two hour drive from the village. Village leaders consider Jacob an extraordinary fellow despite his relatively young age (mid 40s). "Jacob has been instrumental in attracting funds from our diaspora community" says one of the association leaders. His motivation is a desire to give back to his village. "He was embarrassed to find that his school was in a very poor condition. He then promised to help revive the school" says one participant. Jacob's initiative was inspired by similar initiatives in the same major urban centre. The first intervention was mobilizing funds for improving primary education in Mwembeni ward: "We started with education because of a critical shortage of desks. In 2012, there was a deficit of 960 desks. We organized a fundraising and succeeded to raise eighteen million shillings in cash and pledges amounting to sixteen million shillings. Out of the eighteen million, we spent seventeen million to buy 244 desks and distributed equally to six primary schools" (Chairperson of EDAM).

In 2009, the association decided to conduct another fund raising event in Dar es Salaam and elected a member of the village diaspora, and former prime minister, to lead the initiative:

"We formed a small committee led by the former prime minister. However, the committee did not succeed in organizing the fund raising 
event as things were politicized. People thought that the former prime minister had a hidden agenda and was looking for his own popularity. Nothing happened and we were forced to postpone the initiative [...]. We learned a lesson, we now don't associate with politicians. We want to build the trust of common people... people want to see results" (Chairperson of EDAM).

In 2014, the association conducted a fundraising event in the same major urban centre and raised sixty million Tanzanian shillings as pledges and twenty in cash:

"This time the initiative was led by two young men who live there, one is a successful businessman; the other was a district commissioner and now a regional commissioner in Southern Tanzania. We [leaders of the association] approached them and asked for their help. They invited their friends and the business community. After the fundraising event, Jacob volunteered to follow-up on people who pledged and was able to collect an additional forty million shillings" (Chairperson of EDAM).

These figures represent the total amount of money raised without taking into account the cost of organizing the event.

EDAM leaders established accountability mechanisms (written and verbal reporting in regular monthly meetings) for village institutions receiving EDAM funds and closely supervise activities financed by the association. Another form of formal accountability is the labelling of donated goods: "If you go to the primary school now you will see most of the desks inscribed "Wazee wa Maendeleo" which means they were made from the money donated by the elderly men association" (COWSO leader, Mwembeni). Ad hoc reports from the villagers on the general performance of service providers to EDAM members are another form of informal accountability. Yet another can be witnessed during village feasts. For example, Jacob organized a feast at his house in the village and invited ward leaders (councillor and Ward Executive Officer), village leaders (village chairperson, VEO and hamlet chairpersons) as well as heads of public institutions, including COWSO leaders, head of police, magistrate of the primary court, head teachers of three primary schools and the medical officer of the health centre. All leaders were given a chance to report publicly on the performance and status of their institutions to the Elderly-men for Development Association of Mwembeni.

The success of EDAM prompted the district water engineer to suggest to villagers to raise funds themselves for repairing broken pumps in similar fund raising events. The villagers accepted the challenge, but failed: "We tried to mobilize resources from our diaspora community in Dar es Salaam. We set up 
an organizing committee to prepare a budget for hiring a venue and buying dinner to all invitees. In the end we cancelled the event as we realized that the cost for organizing the fundraising event was higher than the money we wanted to raise to finance the repair of a broken pump" (COWSO leader, Mwembeni). Less demanding activities are more successful, for instance when EDAM representatives accompanied a district water technician to Nairobi to ensure that the spare part bought for a broken water pump was durable: "Forget about the six million shillings we asked from the district. This is a Japanese made pump [citizens think of Japanese spare parts as durable] and we bought it as a complete system [motor and switch board]" (EDAM leader, Mwembeni).

In Table 6.1, we summarize perceptions of actors on their responsibilities and those of others in improving rural water supply. Diagonal and shaded cells summarize perceptions of actors on their own responsibilities, while offdiagonal cells summarize the perceptions of actors' regarding the responsibilities of the others. 
Table 6.1: Perceptions of actors on their roles

\begin{tabular}{|c|c|c|c|c|}
\hline 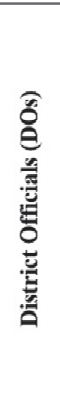 & 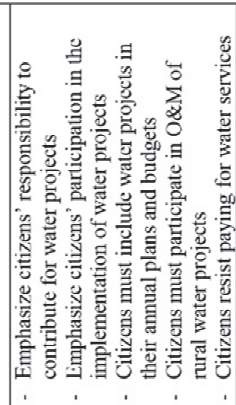 & 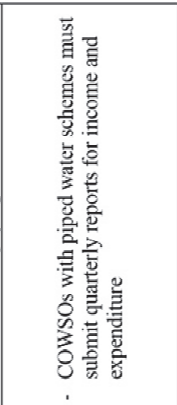 & 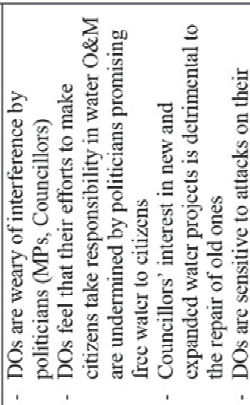 & 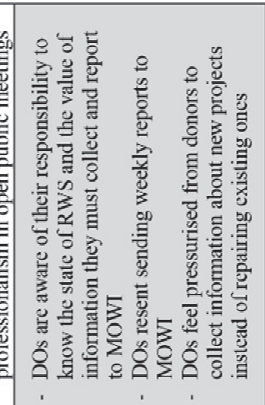 \\
\hline & 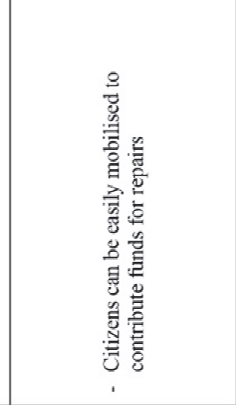 & 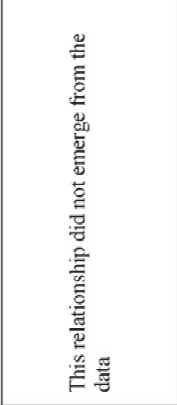 & 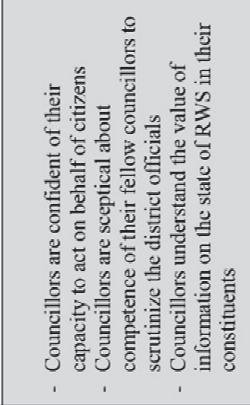 & 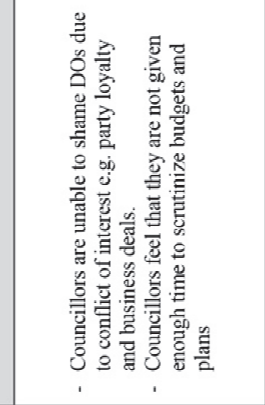 \\
\hline $\begin{array}{l}\text { 总 } \\
\text { 童 }\end{array}$ & 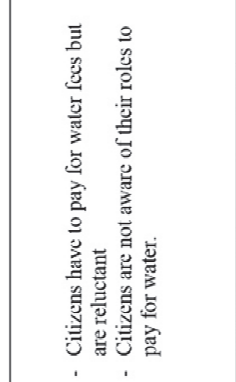 & 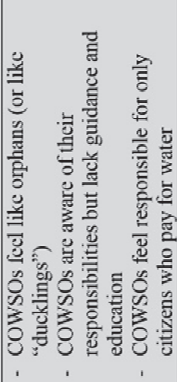 & 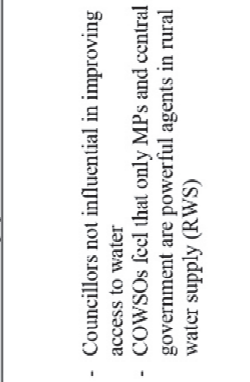 & 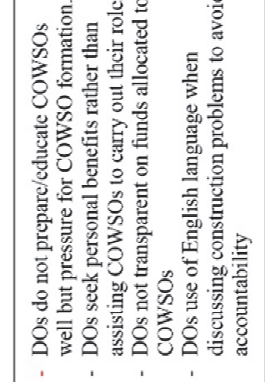 \\
\hline 颜 & 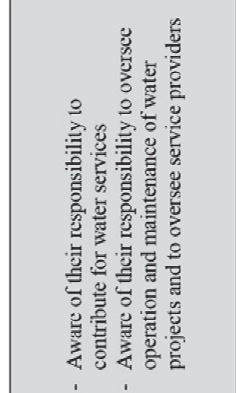 & 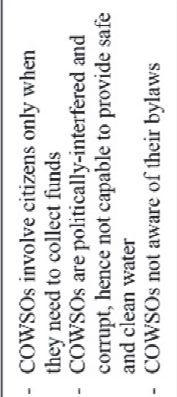 & 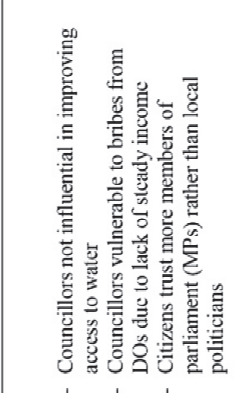 & 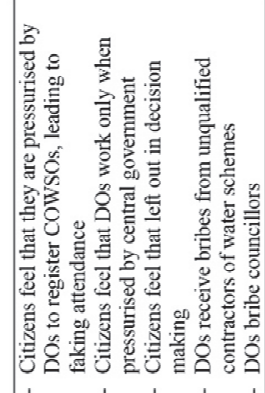 \\
\hline$=$ & 厗 & $\begin{array}{l}\text { o } \\
\text { on } \\
\text { on }\end{array}$ & 常 & 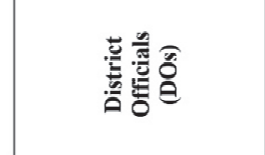 \\
\hline
\end{tabular}




\subsection{Discussion and conclusions}

Our point of departure in this chapter were claims by researchers and development practitioners that citizen apathy and the ignorance of rural water supply actors of their formal responsibilities impede the improvement of rural water supply in general, and in particular the use of ICT in the sector. Our findings are more optimistic.

First, the vibrancy of the Elderly-men for Development Association of Mwembeni (EDAM) contradicts the apathy claim. EDAM, like other grassroots movements in Tanzania, represents an "assertion of community values and solidarity over and against the bureaucratisation of the state [...] It is a movement of the 'weak' [...] with all-inclusive membership and a leadership accountable to the village assembly." (Heald, 2002, p. 22). Peasants in Tanzania have a decades-long tradition of resistance to being "captured" by the state (Hydén, 1980), ever since the Ujamaa period, which promised them ambitious rural water supply schemes if they resettled in new villages (Therkildsen, 1988). The peasant ethic of mutuality and reciprocity eventually saved the peasants from the heaviest burdens of forced resettlement, which was eventually abandoned, while the water schemes rapidly deteriorated. The peasants' uncanny ability to opt out of resettlement via covert resistance (e.g. foot-dragging) and their tenacity in preserving their way of life prevailed. Their resilience to state interventions "comes as no surprise if one bears in mind that the institutional order in Tanzania and its colonial and postcolonial legacy never really demonstrated their superiority in providing justice and prosperity." (Rottenburg, 2009, p. 141). Mulqueen (2009) argues that Tanzanian citizens carefully and continuously negotiate their relationship with the state with, what she calls, the "politics of getting by". She identified two key ways in which citizens engage in the "politics of getting by." The first way includes engagement in subsistence agriculture and informal economy, networks of interdependence within communities and families, and the ways in which citizens circumvent the state in order to achieve their aims. The second way involves an effort on the part of citizens to keep the state intact, "to keep it at a manageable distance and as such create breathing and operating room for local social structures. By keeping the state intact, citizens can at least rest (somewhat) assured that they will be able to continue to get by on a day to day basis" (p. 5) without too much state interference. In this light, EDAM and the village diaspora appear as informal members of the rural water supply sector in Mashujaa and constitute a useful reaction and avoidance of the rigidity of the formal program.

Second, as Table 6.1 shows in the diagonal and shaded cells, citizens, COWSOs, councillors and district officials are knowledgeable to a large extent of their own formal responsibilities and communication channels outlined in 
policies, legislations and regulations. In focus group discussions and in interviews, all actors gave rich justificatory accounts of their actions in rural water supply to people whose opinion they value and whose esteem they seek. These people include this researcher family and kinsmen, friends, co-workers, co-religionists, and people in their profession (Pritchett, 2013). Not only are they aware of the formal responsibilities of other actors (non-diagonal cells of Table 6.1), but also of what others are actually doing informally. It is quite possible that the relatively high level of awareness is the result of substantial capacity building efforts of the Netherlands Development Organisation (SNV), which has been coaching citizens, district officials and councillors on their responsibilities for their water facilities in 22 districts, including Mashujaa (Tilley, 2013). Further confirmation of this awareness, came at the SEMA app workshop, which brought the entire research team together with councillors, district officials and COWSO leaders from the four selected villages. District water officials saw in the SEMA app a tool that would exonerate them from accusations of corruption, help them coordinate planning activities across departments and improve budget planning, determine the water coverage in the district, identify areas with acute problems and instruct COWSOs on measures to take immediately upon breakdown. Councillors saw in the SEMA app a tool that can keep them informed on water problems in their wards and help them mobilize citizens to contribute money if funds are not available at the district level. Finally, COWSOs saw in the SEMA app a tool that can inform them quickly whether the LGA has the capacity to solve the problem and save time and transport costs. In sum, district water officials saw the potential of the app as a streamliner of their formal "responsibilities", while COWSOs and councillors perceived the app as an improvement of their formal "communication channels".

However, district water officials were weary of sharing the SEMA app with councillors: "The way I see it, SEMA is a working tool for the district water department. In that case, councillors are outside this tool but they will meet with the generated information at the ward development committee (WDC). This is a working tool for professionals." (Senior district official). They refused to see the SEMA app as a collective tool providing information on rural water supply to all four actors, and facilitating them in carrying out their formal responsibilities, but as an exclusive tool for the district water bureaucracy. In other words, district water officials refused to accept councillors as formal "members" in the monitoring the functionality of rural water points. Citizens, COWSOs and councillors should only have periodic access to the outputs of the app in the form of reports.

Third, one of the causes of the sub-standard state of rural water supply is the tension between "the re-centralization process on the one hand (WSDP) and a "decentralization by dumping" process (communities assumed to operate their 
own supplies) on the other. Structurally key decision making on planning, and approval for allocation and spending of resources is driven by national priorities which are determined by the central government." (Senior WASH consultant in Mashujaa). The expectations placed on the fledgling formal system of rural water supply are not only unrealistic, as Andrews et al. (2013) argue, they are also contradictory. The contradictory expectations made upon the key actors erode their incentive to take full responsibility and ownership.

COWSOs are too fragile for their formal role ("we are like ducklings"). As a coping strategy, they resort to informal responsibilities and communication channels (Table 6.2). They give an account on their performance only to paying customers and EDAM leaders and are pressurized from the district to fake minutes of meetings. Unsalaried councillors, torn between their loyalty to the party, their responsibility to oversee the district council, and their private firms, which secure their livelihood, scrutinize and deliberate on district plans in closed party meetings and refrain from asking questions in public meetings. Instead of playing one role, they play many contradictory roles simultaneously. District officials only instruct COWSOs with the ability to pay for repairs through informal meetings (face to face or phone calls) and appear to conspire with councillors when water projects are presented in council meetings for approval, however, in practice they stick to one rigid role - using the same template to all COWSOs. Overburdened with the excessive upwards reporting, which they consider detrimental to their day-to-day work, district officials are forced to give lower priority to technical and financial assistance, downwards, to cowsos.

In Table 6.2 we compare formal and informal responsibilities, and communication channels of citizens, COWSOs, Councillors, and District Officials. We distinguish between information- and non-information intensive (in)formal responsibilities and communication channels, since new ICTs such as the SEMA app are more likely to improve information-intensive responsibilities and communication channels. Finally, we label informality either as useful/useless for citizens or as breaking or not the laws or the formal procedures. 
Table 6.2: Formality and informality versus roles

\begin{tabular}{|c|c|c|c|c|c|c|}
\hline & 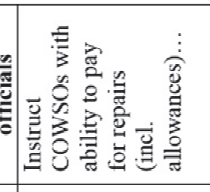 & 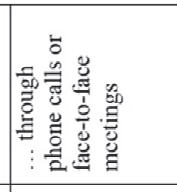 & 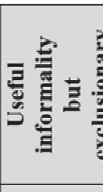 & 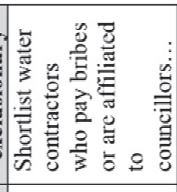 & 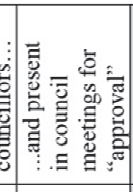 & 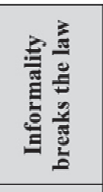 \\
\hline 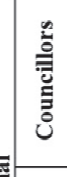 & 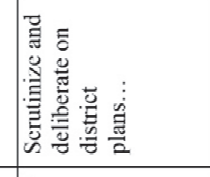 & 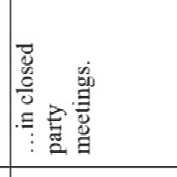 & 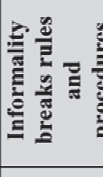 & 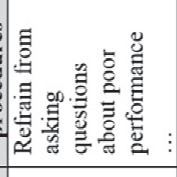 & 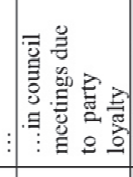 & 跣 \\
\hline $\begin{array}{l}0 \\
0 \\
0 \\
0 \\
0\end{array}$ & 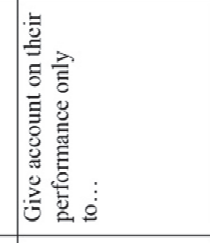 & 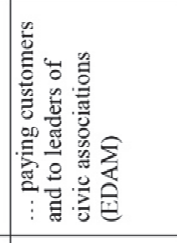 & 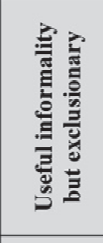 & 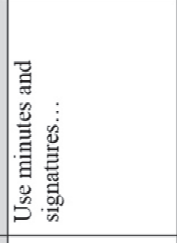 & 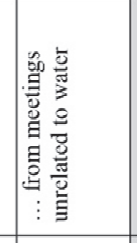 & 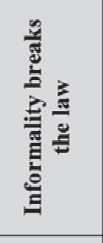 \\
\hline 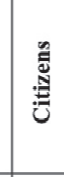 & 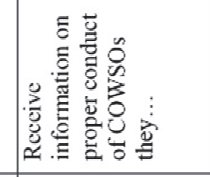 & 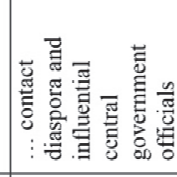 & 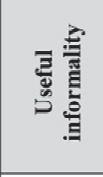 & 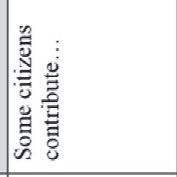 & 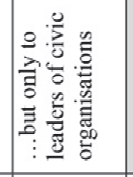 & 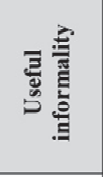 \\
\hline & 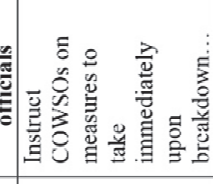 & 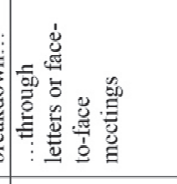 & & 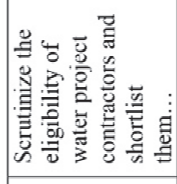 & 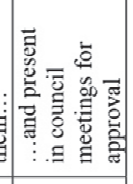 & \\
\hline a & 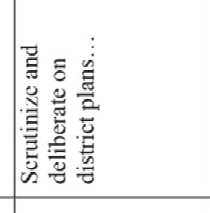 & 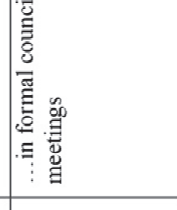 & & 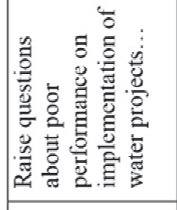 & 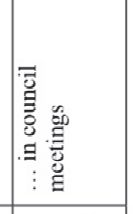 & \\
\hline 客 & 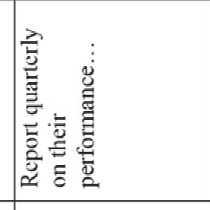 & 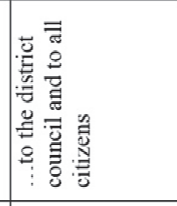 & & 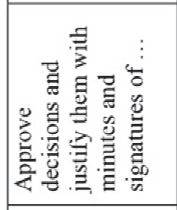 & 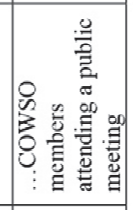 & \\
\hline : & 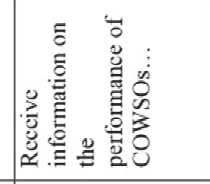 & 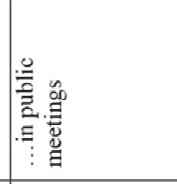 & & 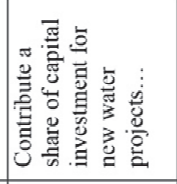 & 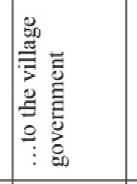 & \\
\hline \multirow[t]{2}{*}{$\frac{5}{4}$} & 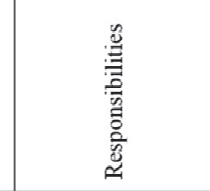 & 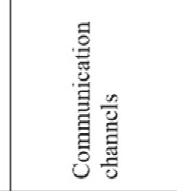 & & 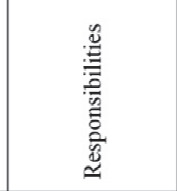 & 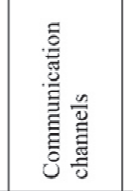 & \\
\hline & دي!su & орешнас & & 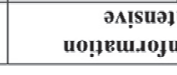 & & \\
\hline
\end{tabular}


Fourth, some instances of informality are useful or useless to citizens or break (or not) the law/rules/procedures (Table 6.3). Informal citizen behaviour is the only one that does not break the law, regulations and procedures and is useful to them. It improves their access to water, for instance when they contribute money for capital investment or to finance repairs to leaders of civic associations, or when they contact the diaspora to get advice about village water supply. Informal COWSO behaviour is meant to comply with demands by district council officials, for instance when COWSO leaders have to fake meeting minutes and, as a result, break the law but do not improve water supply. Informal councillor behaviour, for instance, when they refrain from asking questions in council meetings, or shift issues to party meetings instead of formal public meetings, is not useful to citizens in any of its manifestations. Informal behaviour of district officials does break the law and is useful only to a selected group of citizens, thus exclusionary. When district officials respond only to COWSOs with ability to purchase spare parts and/or offer allowances to district water technicians, they are not breaking any law but their practices deny services to the poor who cannot afford paying the fees. In sum, a large part of informal behaviour by COWSOs, councillors and district officials is not useful to citizens and is exclusionary even when it is useful to citizens.

Table 6.3: Comparison between useful/useless informality to citizens

\begin{tabular}{|l|l|l|}
\hline & $\begin{array}{l}\text { Informality breaks the } \\
\text { law/rules/procedures }\end{array}$ & $\begin{array}{l}\text { Informality does not break the } \\
\text { law/rules/procedures }\end{array}$ \\
\hline $\begin{array}{l}\text { Informality useful to } \\
\text { citizens }\end{array}$ & $\begin{array}{l}\text { District officials instructing only COWSOs } \\
\text { with ability to pay for repairs (exclusionary) }\end{array}$ & $\begin{array}{l}\text { Citizens contacting the diaspora } \\
\text { Citizens contributing money to civic } \\
\text { organizations (EDAM) }\end{array}$ \\
\hline $\begin{array}{l}\text { Informality useless } \\
\text { to citizens }\end{array}$ & $\begin{array}{l}\text { Councillors participating in closed party } \\
\text { meetings } \\
\text { COWSO faking minutes } \\
\text { COWSOs not reporting to the district council } \\
\text { District officials shortlisting water } \\
\text { in council meetings } \\
\text { counctors who pay bribes or are affiliated to }\end{array}$ & \\
\hline
\end{tabular}

Fifth, the systems approach to the study of organisations teaches that informality, including the kind that breaks the law, rules and procedures cannot be suppressed by decree. Informality can take different, perhaps more desirable forms only when changes are made to the formal structures themselves. One such change to the formal structures of rural water supply could be institutionalised through the SEMA app. The SEMA app could become a new formal communication channel designed as a transparent dashboard that informs simultaneously citizens, COWSOs, councillors and district officials of the functionality of water points in all villages in the district. This may lead to new informal structures within rural water supply that are more conducive to improvement of rural water services at the district and village levels, but difficult to predict. 
The timing is right for an intervention of this kind, because of the Payment-byResults (PbR) pilot proposed by DFID in Tanzania in 2013. The PbR pilot is a $£ 78$ million incentive to central and local government to maintain and expand access to rural water points within each one of the 50 pilot districts. $£ 1,500$ will be paid for each functioning water point but not for new ones. Thus local government will have a strong incentive "to maintain existing water points in a sustainable manner and to fix broken water points instead of simply building new ones [...] Payments will be made upon an independent verification of results, building on the existing Water Point Mapping System." (Janus \& Keijzer, 2015, p. 12). The district will have more financial autonomy and the tension between the re-centralization (WSDP) and "decentralization by dumping" will be eased. 


\section{References}

Andrews, M., Pritchett, L., \& Woolcock, M. (2013). Escaping Capability Traps Through Problem Driven Iterative Adaptation (PDIA). World Development, 51, 234-244. doi: http://dx.doi.org/10.1016/j.worlddev.2013.05.011

Booth, D. (2015). Still watering white elephants? The blueprint versus process debate thirty years on In A. M. Kjær, L. E. Pedersen \& L. Buur (Eds.), Perspectives on politics, production and public administration in Africa, Essays in honor of Ole Therkildsen. Copenhagen: Danish Institute for International Studies.

Braathen, E., Chaligha, A., \& Fjeldstad, O.-H. (2005). Local governance, finances and service delivery in Tanzania: A summary of findings from six councils. Oslo, Norway: Norwegian Institute for Urban and Regional Research (NIBR).

Chowns, E. (2015). Is Community Management an Efficient and Effective Model of Public Service Delivery? Lessons from the Rural Water Supply Sector in Malawi. Public Administration and Development, 35(4), 263-276. doi: 10.1002/pad. 1737

Fung, A., Gilman, H. R., \& Shkabatur, J. (2013). Six Models for the Internet plus Politics. International Studies Review, 15(1), 30-47. doi: $10.1111 /$ misr. 12028

Giné, R., \& Pérez-Foguet, A. (2008). Sustainability assessment of national rural water supply program in Tanzania. Natural Resources Forum, 32(4), 327342. doi: 10.1111/j.1477-8947.2008.00213.x

Heald, S. (2002). Domesticating Leviathan: Sungusungu Groups in Tanzania Working Paper No. 6. London, UK: Development Studies Institute (DESTIN), London School of Economics.

Holzer, B. (2014). The two faces of world society. In B. Holzer \& T. Werron (Eds.), From Globalization to World Society: Neo-Institutional and Systems-Theoretical Perspectives. London/New York: Routledge.

Hydén, G. (1980). Beyond Ujamaa in Tanzania: underdevelopment and an uncaptured peasantry, London. Berkerly and Los Angels: University of California Press.

Iacono, J., Brown, A., \& Holtham, C. (2009). Research Methods - A Case Example of Participant Observation. The Electronic Journal of Business Research Methods, 7(1), 39-46.

Janus, H., \& Keijzer, N. (2015). Big Results Now? Emerging Lessons from a Result-Based Aid in Tanzania Discussion Paper 4/2015. Bonn, Germany: Deutsches Institut für Entwicklungspolitik (German Development Institute).

Kjellén, M. (2000). Complementary Water Systems in Dar es Salaam, Tanzania: The Case of Water Vending. International Journal of Water Resources Development, 16(1), 143-154. doi: 10.1080/07900620048626 
Kjellén, M., \& McGranahan, G. (2006). Informal Water Vendors and the Urban Poor Human Settlements Discussion Paper Series London, UK: International Institute for Environment and Development (IIED).

Kühl, S. (2013). Organizations: A Systems Approach (P. Schmitz, Trans.): Routledge.

Mulqueen, T. (2009). The Politics of Getting By: Understanding Political Stability in Tanzania. Brookyling College Undergraduate Research Journal, 1.

Nganyanyuka, K., Martinez, J., Wesselink, A., Lungo, J. H., \& Georgiadou, Y. (2014). Accessing water services in Dar es Salaam: Are we counting what counts? Habitat International, 44, 358-366. doi: http://dx.doi.org/10.1016/j.habitatint.2014.07.003

Pritchett, L. (2013). The World Bank and public sector management: what next? International Review of Administrative Sciences, 79(3), 413-419.

Rottenburg, R. (2009). Far-fetched facts. A parable of development and humanitarian aid (A. Brown \& T. Lampert, Trans.). Cambridge, Massachusetts \& London, England: The MIT Press.

SNV. (2010). Public Accountability in Tanzania Initiative: Brief 1: Approach, Results $\&$ Operational Lessons http://www.snv.org/public/cms/sites/default/files/explore/download/brie f_1_public_accountability_in_tanzania_pata_initiative.pdf

Taylor, B. (2011b). Maji Matone hasn't Delivered. Time to embrace failure, learn and move on. Retrieved from http://blog.daraja.org/2011/12/majimatone-hasnt-delivered-time-to.html

Therkildsen, O. (1988). Watering White Elephants: Lessons from DonorFunded Planning and Implementation of Rural Water Supplies in Tanzania. Uppsala: Scandinavian Institute of African Studies.

Tilley, H. (2013). Unblocking Results: Rural Water in Tanzania. London, UK: Overseas Development Institute.

UNDP. (2014). Tanzania human development report 2014: Economic transformation for human development. Dar es Salaam, Tanzania: Economic and Social Research Foundation.

UNICEF/WHO. (2015a). Progress on Sanitation and Drinking Water: 2015 Update and MDG Assessment. Geneva: UNICEF and the World Health Organization.

United Republic of Tanzania. (1982). The Local Government (District Authorities) Act, 1982. Dar es Salaam, Tanzania: United Republic of Tanzania.

United Republic of Tanzania. (1998a). Local Government Reform Programme Policy Paper on Local Government Reform. Dar es Salaam, Tanzania: Ministry of Regional Administration and Local Government.

United Republic of Tanzania. (2002b). National Water Policy 2002. Dar es Salaam, Tanzania. 
United Republic of Tanzania. (2006). Water Sector Development Programme (2005-2025) Consolidated Report. Dar es Salaam, Tanzania: Ministry of Water.

United Republic of Tanzania. (2009). Tanzania Water Supply and Sanitation Act (2009). Dar es Salaam, Tanzania: United Republic of Tanzania.

United Republic of Tanzania. (2010). Mwongozo Kuhusu Uundaji na Usajili wa Vyombo aya Watumiaji Maji Vijijini (Guidelines for Establishment and Registration of Community Owned Water Supply Organisations). Dar es Salaam, Tanzania: Ministry of Water.

United republic of Tanzania. (2013c). The water sector status report 2013. Dar es Salaam, Tanzania: Ministry of Water.

United Republic of Tanzania. (2015a). Processes \& Procedures for Updating Rural Water Point Data in Tanzania: User Manual. Dar es Salaam, Tanzania: Ministry of Water, Rural Water Supply Division (RWSD).

Welle, K., \& Williams, J. (2014). Monitoring and addressing governance factors affecting rural water supply sustainability: Regional approach paper based on Global Water Initiative East Africa Governance into Functionality monitoring of water schemes implemented in Ethiopia, Tanzania and Uganda Regional Approach Paper. Kampala, Uganda: Global Water Initiative - East Africa.

Welle, K., Williams, J., \& Pearce, J. (2016). ICTs Help Citizens Voice Concerns over Water - Or Do They? IDS Bulletin, 47(1), 41-51. doi: http://dx.doi.org/10.19088/1968-2016.105 


\section{Chapter 7}

\section{Working with the grain: How amenable to digital transformation is the monitoring and repair of rural water points in Tanzania? ${ }^{24}$}

\footnotetext{
24 Based on Nganyanyuka, K., Martinez, J., Lungo, J., Verplanke, J., \& Georgiadou, Y. (2017). Working with the grain: How amenable to digital transformation is the monitoring and repair of rural water points in Tanzania? Information Technologies \& International Development, 13, XXXX - XXXX. (In press).
} 


\begin{abstract}
Rural water services are still not working for poor people. The rising mobile phone penetration in Africa raised hopes in the development community that mobile phone-based ICT platforms could digitally transform rural water supply services. Our approach to platform development is "working with the grain" of the information flow between citizens and district officials, in view of emerging funding opportunities for water point repair in Tanzania (Payment-by-Results). We distinguish between discretionary and transaction-intensive tasks in the information flow. An ICT platform for the monitoring and repair of rural water points should start by digitally transforming tasks with high transactionintensiveness and low discretion that occur outside village and district institutions. Actors in rural water supply should collaboratively simplify formal rules and procedures that govern information flows within local institutions, before considering further digitization.
\end{abstract}

Key words: Rural water services, information flow, discretion, transactionintensiveness, mobile phone-based ICT platforms, rural water point, Tanzania, Payment-by-Results.

\title{
7.1 Introduction
}

Sustaining functional rural water supply infrastructures has been a challenge in sub-Saharan Africa (Giné \& Pérez-Foguet, 2008). Recent studies show that new hand pumps and diesel-powered piped water schemes become nonfunctional a few years after installation. In Tanzania, nearly half of rural water points are not functional (United republic of Tanzania, 2013c) and about 20\% of newly constructed water points become non-functional within one year. Contributing factors include poor post-construction services (United Republic of Tanzania, 2002b), lack of technical and financial capacity of rural citizens to effectively operate and maintain water projects (Jiménez \& Pérez-Foguet, 2011; Mayo \& Nkiwane, 2013) and lack of reliable access to appropriate and affordable spare parts (Giné \& Pérez-Foguet, 2008; Jiménez \& Pérez-Foguet, 2011). Villagers quickly abandon defunct water schemes, return to traditional, unimproved water sources (ponds and streams) and endanger their health and well-being (UNICEF/WHO, 2015a).

Tanzania's rural water woes are chronic. In 1971, the first rural water policy declared that all rural households should have access to safe water within 400 meters by 1991. Donors were quick to support this ambitious goal by financing, planning and implementing rural water supply schemes across the country (Therkildsen, 1988). By the late eighties, rural water plans were "collecting dust" (p. 51) while donor-funded water schemes ceased to function soon after being handed over to users. In 2002, the government declared the National Water Policy (NAWAPO 2002), under which grassroots "user groups are not 
only responsible for operating, maintaining and sustaining the infrastructure; they are also responsible for planning and managing it for the entire water sector in Tanzania" (United Republic of Tanzania, 2006, p. 3). In 2006, the Water Sector Development Program (WSDP) (2006-2025) was launched, funded by donors with US $\$ 2$.3billion. Finally, from 2010 to 2013, the first ever, nation-wide, digital information system was implemented by the Ministry of Water and Irrigation (MoWI), funded by the World Bank.

The information system, known as the Water Point Mapping System (WPMS), aims to provide in digital form the status (functional, non-functional, needing repair) of all rural water points to inform district-level and national planning and budgeting for repairs. In 2013, it became tightly coupled to the Paymentby-Results (PbR) pilot proposed by the Department for International Development (DFID). PbR is a $£ 78$ million incentive to government to maintain and expand access to rural water points within 50 pilot districts. It pays $£ 1,500$ to local governments "to fix broken water points instead of simply building new ones [with] payments made upon an independent verification of results, building on the existing Water Point Mapping System" (Janus \& Keijzer, 2015). DFID's ambition is clearly premised on the quality of WPMS data, delivered by district water departments around the country. The criteria for distributing funds to eligible district councils include "a functioning water and sanitation team, a credible water and sanitation plan, and report timely and accurate data on water points" (British High Commission Dar es Salaam, 2017) and were introduced on 30 th January 2017 in Dodoma, the nation's capital.

However, it quickly became clear that WPMS data quality "was far worse than the [Government of Tanzania] GoT and donors had expected. This was an unexpected challenge to both GoT improving delivery of functional water points, and GoT and DFID monitoring outcomes to make PbR payments" (DFID, 2015). The water point data of entire wards within a district had either not been captured at all in the WPMS survey, or have dubious status (Georgiadou et al., 2016). While district water officials know their water points more accurately-due to numerous formal and informal interactions with villagers and village officials at the district capital or in the villages-they often record the data on idiosyncratic paper forms (an extract is shown in Figure 7.1) that are intelligible only to them. Government and donors need a digital bridge to connect the real status of water points in villages to WPMS, in order to secure $\mathrm{PbR}$ payments for repair. 


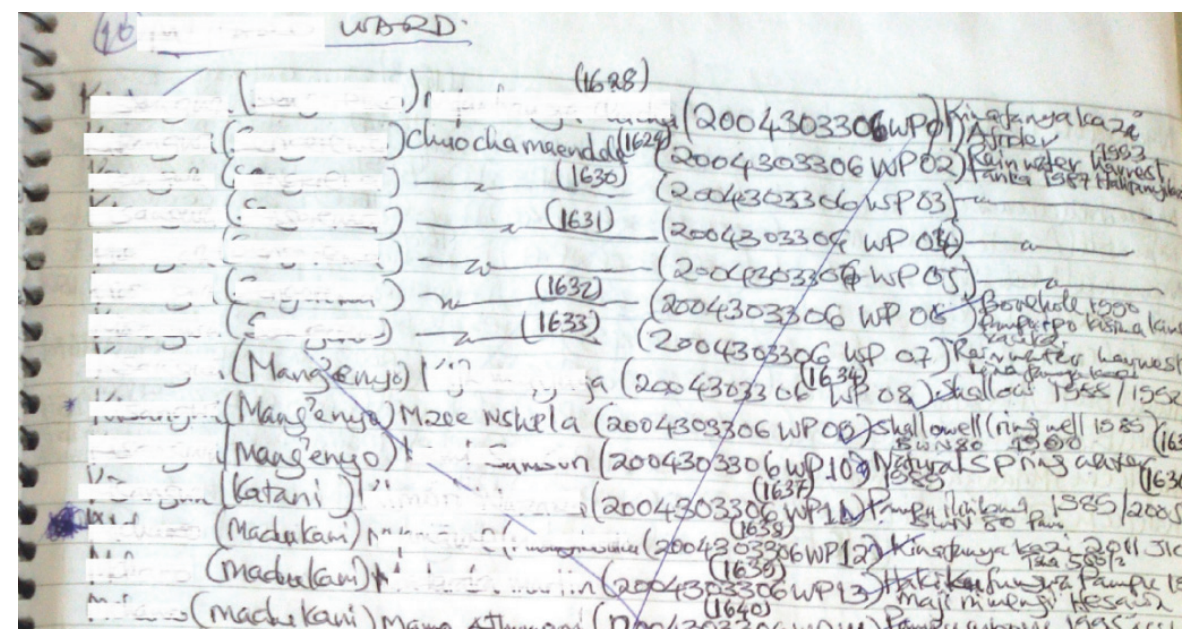

Figure 7.1: Extract of paper form containing water points

This locally nominated and prioritized need (Pritchett et al., 2010) empirically triggered our study. Consultations with stakeholders led us to experiment at the village level with a standard phone-based ICT platform, as simple as the popular MPesa money transfer application, given the rising mobile phone penetration in Tanzania to 63 subscribers per 100 inhabitants (World Bank, 2015).

Our approach complements existing literature on mobile phone-based ICT platforms for solving rural water problems (Georgiadou et al., 2011; Jonoski et al., 2012) empirically and analytically. Several authors have discussed and compared such platforms for water supply (Ball et al., 2013; M. T. Hutchings et al., 2012; Jonoski et al., 2012). The most recent comparison by Welle et al. (2016) surveyed eight platforms, all aiming at water services, in three continents, including two failed platforms in Tanzania. However, these studies either explain the failure in hindsight (an autopsy of sorts) or success of a platform (Welle et al., 2016) or hide patterns of local variation in homogenized national averages of cross-national comparisons (Fox, 2015). The process, the "how to", is missing. No study so far has mapped out the invisible work villagers and district officials do when a water point breaks down and until it is eventually repaired, and, how the detailed representation of this work can be used to decide which, if any, elements of the information flow could be digitized. This research addresses this gap. It asks "to what extent can information flows related to rural water services between the village and the district council be digitally transformed?" It is inspired from the "working with the grain" approach for development interventions (e.g. (Booth, 2012; Levy, 2014b)). 


\subsection{Empirical Context}

This section summarizes recent developments in Tanzania and highlights community water projects in three villages. To preserve the anonymity of informants, which they explicitly requested in order to confide in us and allow us to observe their daily practices, we use fictitious names for the district (Mashujaa) and the three villages (Ufukweni, Mji Mwema, Mwembeni).

\subsubsection{Rural Water Supply in Tanzania}

NAWAPO 2002 and the Water Supply and Sanitation Act (2009) guide rural water services. They shift responsibility for operation and maintenance (O\&M) of community-based water supply projects to communities, via a new village institution, the Community Water Supply Organization (COWSO). O\&M involves three institutional levels: central government, district councils and communities (a ward, village or sub-village-known as hamlet). Central government coordinates, facilitates policy development and capacity building, and monitors performance, but in practice, it emphasizes new schemes rather than maintaining existing ones. For instance, it "allocates less than $6 \%$ of investments for rehabilitation and less than $4 \%$ for district management support and capacity building" (Jiménez \& Pérez-Foguet, 2010, p. 241). In 2013, the President's "Big Results Now!" (BRN) initiative re-established the importance of maintenance of existing water schemes (United Republic of Tanzania, 2015b). However, the community is now expected to contribute $100 \%$ of O\&M costs (United Republic of Tanzania, 2013a). The district council is responsible for investments in rural water supply infrastructure and for technical support to COWSOs-i.e. access to spare parts for broken water points and execution of complex maintenance work. COWSOs are responsible for planning, constructing, financing, and managing water supply projects. They source funds from (i) collection of water fees from users, (ii) contributions from members, (iii) donations, (iv) loans and (v) financial assistance from local government (United Republic of Tanzania, 2009). COWSOs must keep water funds in bank accounts. They can request financial support from the district council only if they "demonstrate ability to sustain water schemes and willingness to pay a portion of the capital costs of the water schemes either in kind or cash" (United Republic of Tanzania, 2009, p. 28).

\subsubsection{Mashujaa District}

Mashujaa is one of the poorest districts in Tanzania. More than half of its 300,000 people live below the poverty line (District Socio-Economic Profile, 2014). Almost $80 \%$ are subsistence farmers and livestock keepers while the rest are petty traders and small-scale fishers in the nearby lake. Ubiquitous Chinese motorcycles ensure transportation to remote areas. Mobile phone connectivity is fairly good at the district capital but variable in the villages. The main sources of water are shallow wells and boreholes fitted with hand pumps 
or motorized pumps powered by diesel or electricity. First introduced in the 1970 s, most of the rural water infrastructure is now crumbling due to old age and lack of maintenance. $69 \%$ of the shallow wells and $55 \%$ of the hand pumps are non-functional (District Socio-economic Profile, 2014).

During the 1970 s and early 1980 s, the government provided free water largely through hand pumps. Between 1985 and 2000, the district received financial assistance from Scandinavian development partners to construct shallow and deep wells and introduced village bank accounts for water funds. Improvements were short-lived as many wells became non-functional after a short period of operation. District officials attribute the failure to extreme drought caused by climate change, lack of community ownership, and vandalism of water pumps and pipes by community members due to "poverty and ignorance" (interview with district water technician). The three village water institutions must cope with $28-40$ years old infrastructure and a variety of extraction and distribution technologies (Figure 7.2).

\subsubsection{Village Water Institutions}

The Ufukweni water committee supplies water to Ufukweni, a village at the lakeshore, with a population of 2600 . It has relatively easy access to the district capital throughout the year except for the rainy season. Travel to the district capital with public buses takes two hours. Mobile phone connectivity is available. The village's piped water scheme features a virtually worn-out diesel-powered water pump installed in the early 1980s. The scheme provides water intermittently due to lack of fuel and regular breakdowns. The village lacked piped water during the entire fieldwork ${ }^{25}$ due to a breakdown in June 2013 that had still not been fixed in March 2015. Most villagers get water directly from the lake while a few buy water (with monthly fees) from a single public standpipe run by a church. When water is available, the water committee distributes it through public standpipes and charges fees at the collection point.

The Cowso of Mji Mwema, a village with 1,500 people, is considered a success story by neighboring villages: "We have been to Mji Mwema and learnt a lot. They have a very strong COWSO that penetrates down to a very low level-every water point has a sub-committee for detailed management. [They] fence their water points to protect them. People know they must remove their shoes when collecting water to keep hygiene" (Mwembeni COWSO chairperson). The COWSOS's good reputation is partly due to its simple and easier to maintain water infrastructure-seven water points with hand pumps, all of which are functioning. It requires less O\&M costs compared to diesel- or electricity-powered schemes elsewhere. Nevertheless, it took

25 Our fieldwork began in November 2013 and ended in March 2015. 
cowso leaders three months to collect enough voluntary contributions to repair a single water pump, broken prior to our fieldwork.

Daily public transport connects the village to the district capital every thirty minutes. Mobile phone connectivity is available but not electricity, so only those few citizens who use solar-powered batteries can charge mobile phones. The villagers' good relations with their diaspora in big cities ensure that public fund allocations are channeled to the village: "In the near future we will shift to electricity-powered water pumps, thanks to our child who works for the national electricity company in Dar es Salaam. He promised us that by next year we should have electricity." (Mji Mwema citizen).

The cowso of Mwembeni village is unique in terms of water scheme complexity and the extent of the catchment area. It comprises twelve members, eight men and four women (a chairperson, secretary, treasurer and nine members) and two committees-one for planning, finance, and education and one for technical matters and security. Two security guards and two pump attendants provided by the district council, support the COWSO members. The water scheme was built in the 1960s and is the oldest of the three. Since then, it has been repaired and improved many times. Between 2007 and 2009, a new water tank, a pump house, and five new public water points were constructed, that reach three more villages. The scheme is now managed as a ward project serving 4 villages and 11,000 people. An electric-powered water pump installed on a borehole pushes water to a tank $3,5 \mathrm{~km}$ up a hill. The long distance results in massive electricity bills and the need for regular replacement of broken pumps. The pump, broken in October 2013, was fixed eighteen months later using funds raised from the village diaspora. The scheme's complexity increases the COWSO's dependence on the district council for paying electricity bills, salaries to pump attendants and purchasing spare parts. Mwembeni displays both urban and rural characteristics. It avails of typically urban facilities, a police station, primary court, health center, primary and secondary schools, stores and market places. It is one of $7 \%$ villages with access to electricity in Tanzania (International Energy Agency, 2011). 


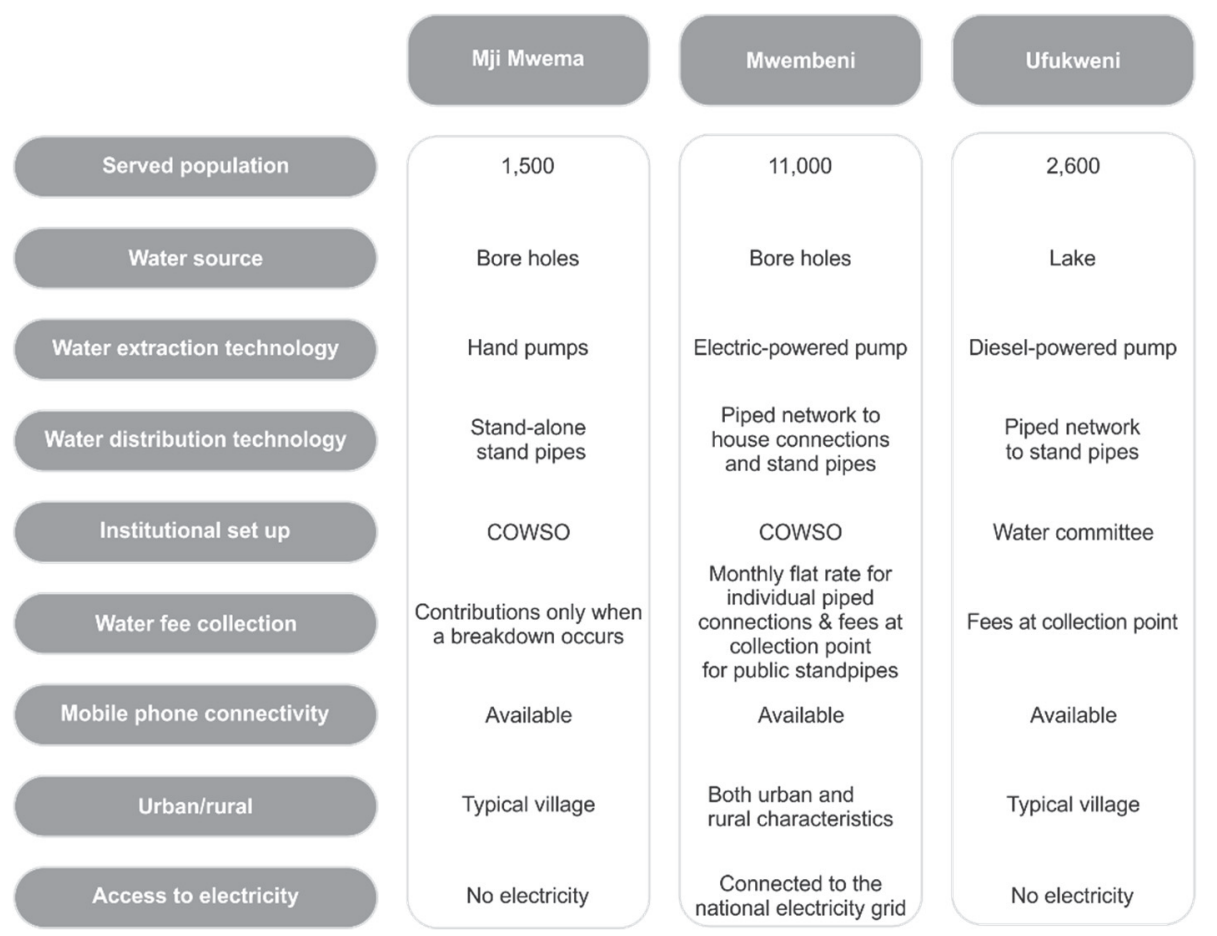

Figure 7.2: Summary of Cowso characteristics

\subsection{Working with the grain, concepts and methods}

Woodworkers working with the grain attend to the orientation of wood fibres and direct their chisel or sandpaper along these. Sanding the wood against its grain may scratch the wood surface and defeat the purpose of sanding in the first place. "Working with the grain" in development interventions (Booth, 2012; Kelsall, 2011; Srivastava \& Larizza, 2013) starts with the way things are on the ground, seeks incremental ways of achieving modest gains (Levy, 2014b) and does not harm the institutional fabric of a country by bypassing local institutions and villagers. In this study, "working with the grain" stands for incrementalism and digitization efforts that can be reversed, redesigned and redeployed until there is a sustainable fit with the empirical setting.

The basic idea is not new. James C. Scott in a speech on his famous book "Seeing like a State", gives an example of how Japanese engineers "work with the grain" in water management. If they want to redesign a stream or small river,

"they will live along that river for a year or two just studying the water movement and different rain patterns at different times of the year and after two years or so they will make a small intervention, a little check 
dam, and then they'll watch for another month or two what the water does around that check dam and in different circumstances, after heavy rainfall, in a drought. So each of their interventions is [...] reversible" (Scott, 2008, p. 10).

\subsubsection{Concepts}

We draw on the framework of (Pritchett \& Woolcock, 2004; World Bank, 2014), which distinguishes between discretionary and transaction-intensive elements in key services ${ }^{26}$ to citizens, and adapt it to micro-level tasks of decision making. Transaction-intensive tasks require a large number of transactions, involving face-to-face contacts between district officials, village water technicians, COWSO members, and citizens, for example a water technician detecting a broken water point and reporting to the cowSO secretary. Discretionary tasks involve decisions based on information that "is important but inherently imperfectly specified and incomplete, and entails extensive professional or informal context-specific knowledge" (Pritchett \& Woolcock, 2004). A village assembly agreeing to contribute funds for repair, or a district official approving a COWSO's request for funds are discretionary tasks.

Transaction-intensive tasks are easily amenable to digitization while discretionary tasks are not because the actor's decisions cannot be mechanized. Non-discretionary and transaction-intensive tasks can easily be codified in computer programs (World Bank, 2016). Tasks that are neither discretionary nor transaction-intensive are lasting dispositions, "propensities to think, feel, and act in determinate ways, which then guide [people] in their creative responses to the constraints and solicitations of their extant milieu" (Wacquant, 2005, p. 316), but digitization does not apply to them. They include the systematic preference of villagers to meetings for distribution of food for hunger relief and to attending funerals rather than COWSO meetings, but also more general patterns of mutuality and reciprocity that pervade village social life and underpin the "economy of affection" in rural Tanzania (Hydén, 1980). Figure 7.3 shows the relationship between task characteristics and amenability to digitization.

\footnotetext{
${ }^{26}$ Key services are those for which some government action is necessary, desirable, and/or inevitable, e.g. improved water supply, sanitation, and health.
} 


\begin{tabular}{|c|c|c|}
\hline Discretionary & $\begin{array}{c}\text { Transaction-intensive } \\
\text { improvement } \\
\text { through digitization }\end{array}$ & $\begin{array}{c}\text { Non transaction-intensive } \\
\text { improvement } \\
\text { through digitization }\end{array}$ \\
\hline Non-discretionary & $\begin{array}{c}\text { Highly amenable to } \\
\text { improvement through } \\
\text { digitization }\end{array}$ & $\begin{array}{c}\text { Lasting } \\
\text { dispositions }\end{array}$ \\
& and & \\
\hline
\end{tabular}

Figure 7.3: Amenability to improvement through digitization

\subsubsection{Methods}

The first author lived in Mashujaa district capital and villages for eight monthsfrom November 2013 to April 2014 and from February 2015 to March 2015. He conducted in-depth interviews in Kiswahili with eight COWSO members, four water technicians, six pump attendants, three security guards, three village chairpersons, three village executive officers and six sub-village chairpersons, seven district officials (including the District Water Engineer (DWE)-the highest ranking water official in the district and supervisor of district water technicians), two ward councillors (locally elected politicians) and several citizens. Participant observation in village assemblies and at the district council gave him a deeper understanding of the interactions between COWSOs and district council, a better appreciation of village life and the difficulties district officials endure when performing their duties. Informal interactions in the market, in canteens and on the street revealed lasting dispositions that interviews cannot capture. He transcribed and translated interviews and fieldnotes into English, and coded and analyzed data in terms of an information flow and task classification. Co-authors regularly visited Mashujaa for meetings and participated in a formal workshop in February 2015, with ward councilors, district officials and COWSO leaders to deliberate on the fieldwork findings. 


\subsection{Information Flow}

We describe the main steps in the information flow between the villages and the district council, the sequence of tasks-mostly according to formal rules and procedures-and actors and time estimates. Figure 7.4 represents a composite information flow representative of all villages.

\section{Step I: Detecting a Water Point Breakdown}

Detection by pump attendants, or security guards or water technicians is the first step and affects the quality of subsequent steps. COWSOs with resident water technicians (more skilled than pump attendants or security guards) diagnose breakdowns more accurately and quickly. COWSOs often use security guards to curb theft of pumps and other expensive parts. In Mwembeni security guards may operate water pumps. In Mji Mwema they work as pump attendants. They collect contributions for repairs, may refuse access to noncontributors and monitor the number of buckets per household to ensure equitable water access during the dry season. Security guards may be employed by the district council and receive a monthly salary, while pump attendants are volunteers receiving a fraction of collected fees as compensation. The pump attendant or security guard reports the problem to a cOWSO or water committee secretary (in Ufukweni), either by mobile phone or face-to-face at the village market.

\section{Step II: Reporting the Breakdown to the District}

The COWSO secretary, in charge of all communications, communicates the breakdown by phone or face-to-face to a local water technician and requests a diagnosis. If a water technician is unavailable locally, the secretary writes a formal letter to the district council to report the problem and request for the district water technician to travel to the village and do the diagnosis.

\section{Step III: Diagnosing the Breakdown}

If the technician is a local man, diagnosis is swift (2-3 hours) depending on the severity of the breakdown. If he is unavailable, due to livelihood-sustaining work (e.g. fishing) or absent (e.g. due to responsibilities at the district council), diagnosis may take 1-2 days. Subsequently, he submits a hand-written report to the COWSO secretary summarizing the inspection and recommending the kind and cost of repair. Only in Mwembeni, where a private printing service is available, can he prepare a typed letter and charge the printing cost to the cowso. Often "I pay for the printing. It is always good to have a printed letter, especially if the letter is forwarded to the district council" (District water technician).

Diagnosis and letter writing may take between a few hours to a whole day. Some of the breakdowns in motorized boreholes may require the technician to 
extract the submersible water pump from the borehole (often more than 50 meters deep) for proper inspection, a process that requires mobilizing a workforce in the village or renting a tripod from the district capital. If the tripod is not in use in another village, it may take three days to deliver. Evidently, water scheme complexity (motorized boreholes) increase the dependence on the district council for technical (water technician) and material (tripod) assistance.

The COWSO secretary must inform users about the outcome of the diagnosis. $\mathrm{S} /$ he issues a written public notice and posts it in popular places such as the market, village government office, important trees, schools, and health facilities. Informing water users about the changes in water supply including breakdowns "is an official requirement, otherwise people get information through word of mouth" (Mwembeni COWSO secretary). In schemes suffering from regular breakdowns, water users can predict not only when these will occur, but also the cause and spread the news by word of mouth, a major source of information in villages. In Ufukweni "[t]he problem of fuel has become so acute that we do not have to tell people the cause of intermittent supply of water. They would just guess that lack of water means there is no fuel. They are often right" (Ufukweni water committee secretary). Under such conditions, dishonest COWSO leaders may use chronic failures to conceal their own negligence.

\section{Step IV: Mobilizing Funds to Finance Repairs}

The water technician's diagnostic report suggests a repair of the breakdown without or with purchase of spare parts. In the first case, the COWSO secretary asks him to proceed with the repair. In the second case, the secretary must convene a meeting of the COWSO steering committee to approve the required expenditure of funds and identify ways to finance the repair. Without minutes of the meeting to authenticate the COWSO's request financial assistance from the district council and withdrawing funds from the bank is impossible.

Organizing this meeting involves setting a date, inviting members and conducting it. The secretary writes invitation letters by hand (except in Mwembeni) and sends them to members' homes, either (i) personally on foot, or (ii) via primary school pupils, or by (iii) hiring motorbikes. The second option is the preferred one. It is free and effective for scattered sub-villages. When letters are ready for distribution, the secretary brings them to a primary school teacher, who hands them over to pupils, to deliver to COWSO members. In Mwembeni, which includes four villages, the secretary distributes letters to four primary schools. He opts for motorbikes but only when the COWSO is in good financial shape and the meeting is urgent: "The ubiquity of motorbikes in our village has facilitated cheap and quick transportation of letters. However, hiring 
motorbikes is only possible when we have funds" (COWSO secretary in Mwembeni).

Organizing a COWSO meeting may take up to two days and even longer. The date should not fall on weekends, public holidays or funerals: "It is challenging to get enough members to record a quorum. We conduct our meetings on weekdays" (COWSO secretary in Mwembeni). Finally, COWSO members travel to the office on hired motorbikes (usually later reimbursed by COWSO). During the meeting, the secretary presents the diagnosis and the members debate which options to use for mobilizing funds: $(A)$ own funds from collected water fees, (B) contributions from water users, or (C) financial assistance from the district council.

\section{Step IV-A: COWSOs Withdraw Funds from Bank Account}

If the COWSO has enough funds in its bank account, members approve the budget and decide to withdraw money. At least two signatories of the bank account are required as well as an authorization by the District Water Engineer (DWE) to make any transaction on the COWSO bank account. First, the COWSO secretary writes a letter to the Bank Manager requesting the withdrawal, and copies the DWE for authorization. At least two signatories must travel by bus to the district capital to deliver the letter to DWE for authorizing and then carry it to the Bank Manager to withdraw money from bank. Usually this process takes one day for preparation while in the village (writing a letter, organizing for bus fare) and another day for travelling to the district capital. Given the moderate distances between the villages and the district capital, it is possible to conduct all banking business in a single day. After the withdrawal, COWSO members hand-the-money-over to the DWE or water technician who facilitates the purchase of spare parts (e.g. water pump), a widely contested practice. District officials claim that purchasing spare parts exceeds the COWSO's skills, while COWSO members view it as an opportunity for profiteering by officials.

If funds are unavailable, COWSO members must consider choices (B) and (C). COWSOs prefer choice (B) when water schemes are low-cost (hand pumps) and fees are charged only for repair. Only the Mji Mwema COWSO claims to have collected contributions from water users to finance a breakdown. The other two communities always request assistance from the district council claiming high repair costs. District water officials are skeptical about these COWSOs' choices: "Prior to [NAWAPO 2002], these two community pipedwater projects were receiving grants for operation and maintenance from the district council and are now dependent" (District water technician).

\section{Step IV-B: COWSOs Collect Contributions from Water Users}

If the COWSO decides to collect voluntary contributions from water users (often all members of the village), the secretary must ask the village 
government to organize a public meeting and collect funds on behalf of the cowso. The meeting objective is to formally present the issue to the villagers, determine per capita contributions, identify strategies to collect funds, set deadlines, and determine which villagers can be exempted. The coWSO secretary writes a letter to the Village or Ward Executive Officer (VEO or WEO) requesting a public meeting. The $\mathrm{V}(\mathrm{W}) \mathrm{EO}$ sets a date and sends invitations to citizens. Calling for a public meeting may take between one to several weeks depending on the season. The $\mathrm{V}(\mathrm{W}) \mathrm{EO}$ may hire a public relations firm to spread the word (only applicable to Mwembeni and Ufukweni), or write letters to hamlet chairpersons who then pass the information to hamlet members through house visits, or post invitation posters at popular village locations. Achieving good attendance is difficult: "we get maximum attendance when we call meetings for distribution of food for hunger relief; otherwise, people always find excuses for not attending. They will tell you that they are going to attend funerals, or go to worship" (Mwembeni WEO).

During the public meeting, the $\mathrm{V}(\mathrm{W}) \mathrm{EO}$ presents COWSO's case and requests villagers to contribute. Old (above 60 years) and disabled villagers are exempted from contributing. Hamlet chairpersons keep an updated list of exempted people; else, the public meeting itself serves to update the list. The chairperson reads aloud the names of household heads and the audience agrees or disagrees with the exemption. Then the COWSO computes and presents each household head's contribution. A deadline is set for hamlet chairpersons or COWSO hamlet representatives to collect money, a process that may take between one and several months.

This mode of fund mobilization is long and unpredictable. The willingness and ability of villagers to contribute cannot be taken for granted and depends largely on the season (farming or harvesting). The obligatory involvement of the village government in collecting contributions on COWSO's behalf is a further challenge. It jeopardizes the COWSO's autonomy and increases the reluctance of citizens to contribute especially when the village government has a poor reputation for fund management.

Step IV-C: COWSOs Seek Financial Assistance from the District Council If the COWSO decides to seek financial assistance from the district council, the secretary writes a letter to the District Executive Director (DED) requesting funds, attaching the cowso meeting minutes, and the signatures of all attendees.

\section{a) Sending a letter to District Executive Director}

The COWSO secretary travels to the district capital to deliver the letter at the DED's office in person, or may ask anybody with official status (VEO/WEO, primary school teachers, water technicians, agricultural extension officers) 
traveling to the district capital to deliver it on his/her behalf. The DED's Registry attendant receives and routes letters to one of the several departments (finance, human resources, water, etc.) in the district council depending on content. An important artefact in routing is the "paper dossier" for each department. Each head of department has his/her own paper dossier that "moves" all department-related letters from the registry to his department and back. The idea is to allow easy handling of letters of similar nature. In practice, significant delays occur when a dossier carries two letters that involve different decision-making routes (personal allowances of a water official vs a COWSO's request for funds).

The Registry attendant first forwards the letter to the DED, who reads such letters only after 2:00pm and decides that the right head of department is the district water engineer (DWE). He returns the letter for filing and instructs the registry attendant to forward it to the DWE. After filing the letter in the DWE'S paper dossier, s/he carries it to DWE's office, a three hundred meters stroll from the Registry. Given the short distance between the Registry, DED, and DWE, moving letters should be a straightforward matter. However, it is not. The speed depends on the availability of the DED ( $s /$ he may be out of town for business) to read the letter, on whether the DWE's paper dossier is at the Registry, and not "on the move" somewhere, so that the letter can be filed in it. Thus:

"sometimes the letter is completely lost because the registry attendant forgets to file the letter when the paper dossier returns to the Registry. Often this is not intentional, the registry is run manually and they have a tremendous amount of letters to deal with" (DWE). Similarly, "We received a call from DWE that he couldn't find the letter that we sent earlier. We had to write another one" (Mwembeni COWSO secretary).

DWEs do not depend on formal letters only. They often receive informal breakdown reports (phone calls as well as face-to-face) breakdown reports from district water technicians visiting village water schemes. But, their hands are tied until the formal letter has moved along the prescribed channels.

b) Funds mobilization within the district council

The lengthy procedure that must be followed until the funds are released to the COWSO bank account deserves to be described in detail.

The DWE fills a request form (dokezo in Swahili, meaning "recommendation"), including a budget and the COWSO letter, and addresses it to the DED. The DWE hands the package to his/her secretary, who carries it to the District 
Treasurer's (DT) ${ }^{27}$ office and hands it over to the DT's secretary. The latter leaves the package at the Treasurer's desk for approval and for issuing a payment voucher. The Treasurer's approval depends on the availability of funds allocated to the water department. If funds are available, the Treasurer approves and orders an accountant to prepare a payment voucher. Depending on the urgency and the timing of the request, the accountant may put requests from the water department on hold while dealing with requests from others:

"One accountant deals with our water budget but he is not always available. The DT office frequently complains about slow internet. I have to follow-up constantly every fund request that we send to DT's office. I need to walk to DT's office and have a face-to-face conversation with the accountant requesting him to prepare the payment voucher. Sometimes the DT secretary helps to remind him" (District official, DWE's office).

Constant follow-ups and long waiting periods do not always end well. Often the Treasurer returns the dokezo to the DWE with the inscription: "Funds exhausted. See next OC [other charges - monthly disbursement of funds from central government]". To this, the DWE remarked sarcastically in writing: "Who exhausted?" followed by a date and his signature. The DWE tried to secure a dedicated own accountant without success:

"We have argued several times that [the accountant] should transfer his desk to the water office but the DT doesn't like the idea. Because sometimes the DWE suspects that [the DT] has money although he claims the opposite. The OC [other charges] for December 2014 was sixty million shillings, the department only spent half of it, and the other half was allocated for repairing a broken pump in Ufukweni. When the DWE requested the remaining funds, he was told that funds were not available. The same happened for January's OC. We were told that twelve million shillings were allocated to our department but when we sent the request we were told there were no funds. Can you imagine someone telling you that you have twelve million and the next day the same person tells you that you have no funds?" (District official, DWE's office).

If the district has funds, the DT directs an accountant to prepare a payment voucher. The accountant prepares and sends it back to DT for signing. The DT signs and gives the payment voucher to the secretary who delivers it to the DED for signing. As usual, DT secretary hands over the payment voucher to

${ }^{27}$ The District Treasury Department, employs three trained accountants, who have several departments in their remit besides the water department, and seven supporting staff. 
DED's secretary who then puts it on DED's desk. Depending on the availability of the DED, it may take up to a week for the signing process to be completed. Then the DED's secretary takes it to the Treasurer's office and hands it over to his/her secretary, who puts the payment voucher on the Treasurer's desk. The DT assigns an accountant to write a bank check, but due to slow internet (a common excuse at the district council) this task causes long delays: "Usually it takes a week for the accountant to write the check. This is when I do frequent follow-ups. I have to go to DT's office every day and if the funds are urgently needed, I sometimes make multiple visits in a day" (District official, DWE's office). 


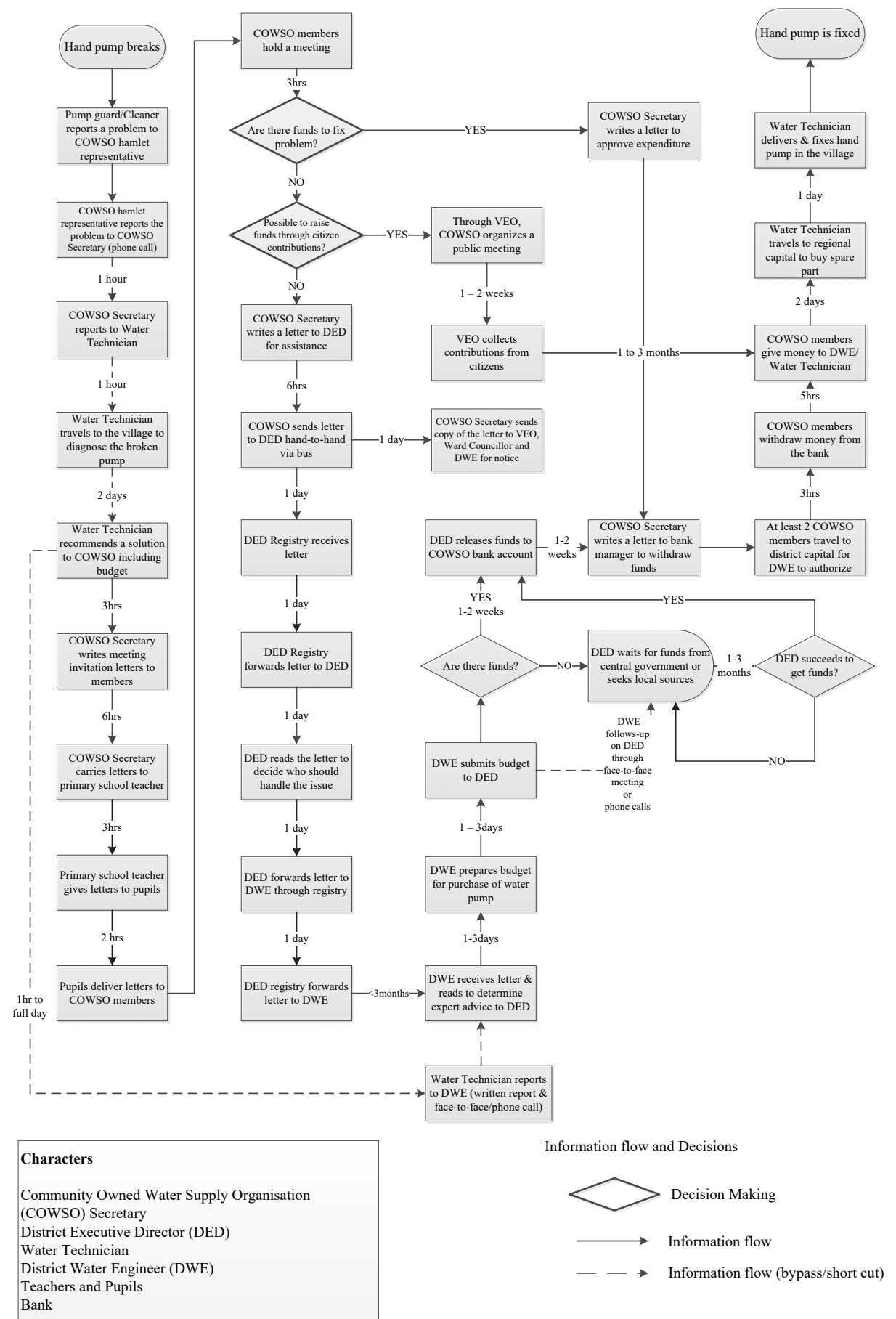

Figure 7.4: Typical information flow 
To facilitate financial transactions, including preparing checks, the district council uses an electronic accounting system connected via internet with the central government Treasury in Dar es Salaam. The district's internet is indeed slow and unreliable. Nevertheless, water officials feel that accountants overuse slowness as an excuse:

"[Accountants] always claim that the internet is slow. However, since we have no ability to verify whether they tell the truth, we cannot do anything but wait for fast internet the same way we wait for the rain. No one knows when fast internet will be available. But when they have to do their work [such as transactions related to personal allowances], then internet is no longer slow" (District official, DWE's office).

When the accountant has sufficient internet speed, s/he prepares a check and forwards to the Treasurer and then to the DED for signing. The DT secretary delivers the check to DED's office and hands over to DED's secretary. DED's secretary records the check number in a logbook before forwarding it to the DED. When DED has signed the check, DED's secretary updates the logbook. DED's secretary then takes the check and submits it to the district cashier. The cashier contacts by phone the COWSO secretary, who then travels to the district capital to collect the check. The DED writes a letter to the COWSO informing them about the disbursement of funds with copy to the Ward Councilor, WEO or VEO. At this stage, the COWSO will have to begin the process of money withdrawal from the bank as described in step (IV-A).

After the accountant has prepared the check, s/he detaches the payment voucher from the paper dossier (carrying old fund request letters). The DT secretary can now deliver the water-related dossier to the Registry. The Registry attendant attaches the newly arrived COWSO letters to it and sends to the DWE for the process to start again. It is worth noting that from the moment the DWE filed the fund request form, his paper dossier was not at the registry any longer. Thus, no letters arriving at the Registry for water matters could be "moved" to the water department, creating a huge backlog! When the district has no funds whatsoever for rural water schemes, the funds mobilization becomes entirely unpredictable. COWSOs are told to wait for the next $\mathrm{OC}$ which can be several months later.

\section{Step V: Purchase of Spare Parts}

Upon receiving money from COWSO members, water technicians begin the purchasing process. Since the district capital is a small town, technicians insist they must travel to the region's capital or to Dar es Salaam or Nairobi to consult with pump distributors: 
"We took with us all technical drawings of the whole water scheme. Having experienced regular problems with other brands, we wanted to get a long-term solution and opted for brand change. We needed expert advice on the type of pump we had to buy" (Water technician, DWE's office).

Travelling long distances, on COWSO's account, causes friction. Although COWSOs are responsible for such purchases, in practice the process is still dominated by district water technicians: "Currently the [COWSO] is doing all the purchases [for] small things. For large spare parts, it is the responsibility of the district council" (Water technician, DWE's office). COWSOs incur all the costs, including travel costs for officials (fare, meals, accommodation and allowances):

"The district council sent the water project manager to Nairobi and his daily travel allowances and hotel costs were borne by us. They said it was cheaper to buy the pump in Nairobi. We were not convinced. Since we are on the receiving end, we had nothing to do but wait for the pump. Our main interest is to see people get water and not politics involved in between" (COWSO treasurer).

\section{Step VI: Fixing the Water Pump}

Upon return from the big city and the arrival of spare parts at the district council, the water technician travels to the village to fix the pump, a process that may take two or three days. The COWSO must inform citizens that the water pump is about to be fixed although this is hardly necessary. The technician's arrival in the village spreads quickly by word of mouth. As soon as he arrives, villagers start following closely the progress and outcomes of the fixing process.

\subsection{Discussion}

Tackling the longest delay in the information flow (Step IV-C: COWSOs seek financial assistance from the district council) matches the Payment-by-Results opportunity, but assumes that the district can deliver digital water point data, compatible with the WPMS. Could a COWSO member, using a simple mobile phone-based ICT platform, provide this data to the district?

\section{Conceptualizing Micro-tasks in the Information Flow}

From the district council's point of view, micro-tasks in steps I to VI (Annex) of the information flow are transaction-intensive and/or discretionary. Microtasks, not handled within village institutions, are transaction-intensive, because district officials must deal frequently and face-to-face with a large number of village officials in over hundred villages in the district. Only the 
tasks' level (low, medium, high) of discretion needs to be refined, for which three factors are relevant (Figure 7.5):

Variety of decision choices determines the level of discretion. It is low when choices are fixed and predetermined, medium when choices are fixed and undetermined, and high when choices vary significantly from one decision to the next. The level of technical skills and experience required to conduct a task and decide which village's needs to prioritize affects discretion. A high level of prior experience and understanding of the job at hand is required to repair a complex breakdown and to prioritize a village. Finally, discretion increases with the district officials' bureaucratic status (e.g. only the DWE can approve cowSO's request for funds).
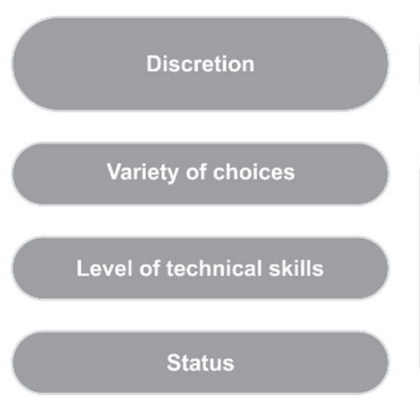

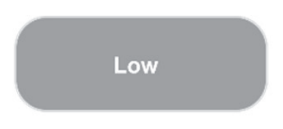

Fixed, pre-determined choices

Anyone can perform the task

No specific bureaucratic status required
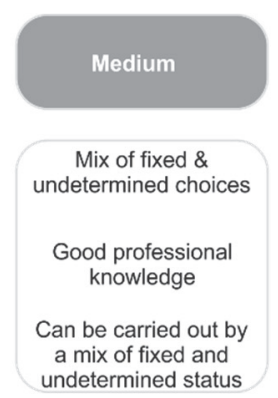

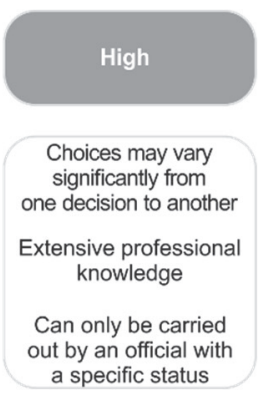

Figure 7.5: Levels of discretion

\section{Internal Functioning of Village and District Institutions and Related Tasks}

All tasks unfolding within local (COWSO and village government) and district institutions are infused with an incredible amount of rules and procedures, mostly formal, but also informal (mobilizing funds from the village diaspora). While some procedures may appear absurd to an outsider, they reflect a deeply embedded bureaucratic culture that is difficult and even counterproductive to dislodge with technological means. Why? It is an old saw of information system design that "the less of its user's behaviour a system encodes, the less functionality it can provide [...] the more behaviour is encoded [...] the more technologies may come to prescribe human activities" (Suchman, 1995, p. 59). Tanzanian villagers, on the one hand, have a well-documented, uncanny ability to covertly resist prescriptions, especially when these originate from the state (Hydén, 1980), and to effectively evade the state, a lasting disposition that arguably contributes to political stability in Tanzania (Mulqueen, 2009). The villagers' covert resistance is not surprising if we bear in mind that the "institutional order in Tanzania and its colonial and postcolonial legacy never really demonstrated their superiority in providing justice and prosperity" to citizens (Rottenburg, 2009, p. 141). District water officials, on the other hand, 
find the increasing pressure from the ministry to report rural water-related information upwards in various formats excessive:

"I am overburdened by the information collection roles and reporting to higher levels which derail me from focusing on other responsibilities. [...] BRN introduced new reporting and information collection formats that are confusing and impossible to handle especially when internet services are poorly available" (District Water Technician).

As Pritchett et al. (2010) argue, any additional "premature load bearing", or pressure on district water officials, based on unrealistic expectations about the improvement of district capacity with digitization, may lead to stress and a weakening or total collapse of capacity. A flexible standards approach to create a modular hierarchy of national, district and village-level water point datasets to release tensions between standardization, required by the Ministry and donors, and localization favored by the district, and accompanied by intensive capacity building would be worth trying (Braa \& Hedberg, 2002).

Tasks in steps IV-A, IV-B and IV-C include a mix of all three levels of discretionlow, medium (attendance to meetings, travelling to carry letters to the district council and withdrawing funds from the bank) and high (approval of the COWSO steering committee to request funds from the DED or the district treasurer). However, while non-discretionary tasks might seem to be easy candidates for digitization, expediting some of them with technology, before new, comprehensive rules and procedures are agreed by all concerned, is not advisable, as they might conflict with the others.

\section{ICT Platform as Gateway between village and district institutions}

Only three tasks in steps I and II are easily amenable to digitization (Figure 7.7). In light of the Payment-by-Results program, we generalized these into a single task "COWSO member regularly (not only when broken) reports the status of water points to the district" and developed a mobile-phone based ICT platform. Stakeholders see value in the platform for different reasons. Senior district officials could "get up-to-date and correct data across all departments in the district". Water officials felt it would exonerate them from accusations of corruption and help them identify villages with acute problems. Ward councillors saw it as a tool to keep them informed of their voters' concerns, while COWSOs saw is a time and transport-costs-saver. Nevertheless, they disagree on "who should receive the reports?" Senior district officials insist that only "the planning department which is coordinating all planning activities and statistics of the district should receive reports" and are weary to share this information with councillors: "The way I see it, this is a working tool for the district water department. Councillors are outside this tool. This is a working tool for professionals" (Senior district official). They also disagree on "Who 
should report?" Few villages have COWSOs in Mashujaa, while most have village executive officers, who are trusted by the district as fellow bureaucrats, but not by the COWSOs and ordinary citizens, given their reputation of questionable management of village funds. Additional digital tools, such as dedicated dashboards for village/ward executive officers and councillors may resolve these tensions without compromising the transparency of water point information to all stakeholders. Ideally, the Ministry would facilitate districtvillage interactions and further incremental digitization with financial support from the donors, in the medium term. It would also mediate between district and village to identify appropriate reporters, beyond COWSO members, in the short term.

Finally, tasks outside village and district institutions include those in step III (diagnosis) that require the physical presence of skilled individuals at the village and can be transformed by building the capacity of COWSOs to repair broken water points without depending on the district council. Tasks in steps $\mathrm{V}$ (Purchase of spare part) and VI (Fixing) may be amenable to digital transformation. Information about breakdowns available transparently and in a timely fashion may provide external market parties with the opportunity to stockpile spare parts efficiently and dispatch technicians to the right locations. A social enterprise could probably provide this service under a business model that would benefit a network of warehouses and technicians down to village level. Figure 7.6 summarizes the amenability to digitization of steps and tasks in Figure 7.7 .

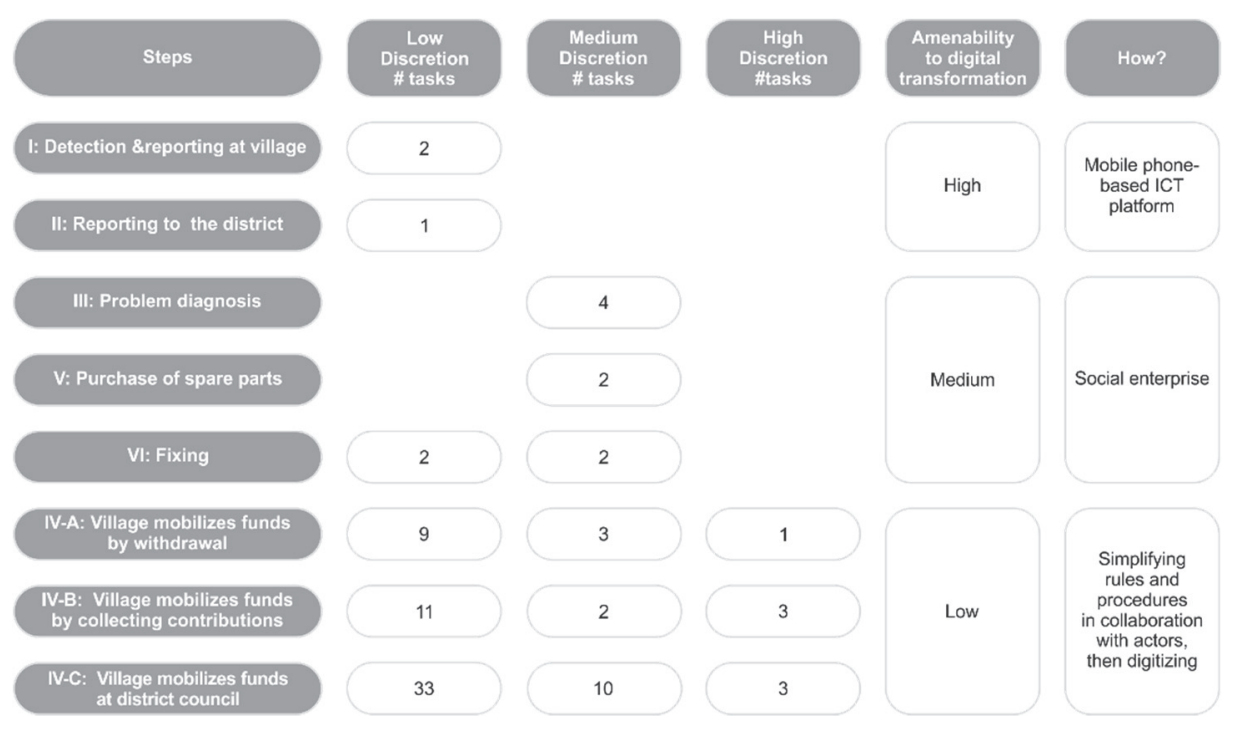

Figure 7.6: Amenability to digitization 
Mwembeni and other communities are now experimenting with a social enterprise, a hybrid water governance model that combines elements of government, community and private sector management.

\subsection{Conclusion}

This study's qualitative portrait of rural water supply reveals the amount of invisible work around access to rural water. It draws attention to aspects of village-district interactions that go unnoticed by the Ministry and donors in distant Dar es Salaam. It exposes lasting dispositions that may hold villagers captive (reluctance to participate in water meetings), exhibits villagers' resourcefulness (mobilizing their diaspora for funding repairs), helps rearticulate taken-for-granted assumptions (regarding profiteering district officials), and shows where opportunities emerge for improvement. In this sense, it empowers villagers, regarded as passive "policy endurers" as well as district officials, regarded as lacking a "monitoring and reporting culture" (Therkildsen, 1988).

"Working with the grain" does not interfere with the internal functioning of village institutions and the district council. But, it renders visible formal rules and procedures within local and district institutions that could be simplified, without disrupting the bureaucratic culture and social fabric in villages. "Rehabilitated" rules and procedures, may help access new funding opportunities, such as Payment-for-Results, and eventually lead to rehabilitated rural water points. Positioning an ICT platform as a possible village-district gateway presumes a willingness to deploy a platform, learn how it can be (ab)used, and redesign it, until a sustainable fit is accomplished. A digital incrementalism of small, reversible changes, sceptical of ICTs that bypass local institutions (Fung et al., 2013), may generate clumsy solutions to rural water services, but an elegant failure becomes less probable. 

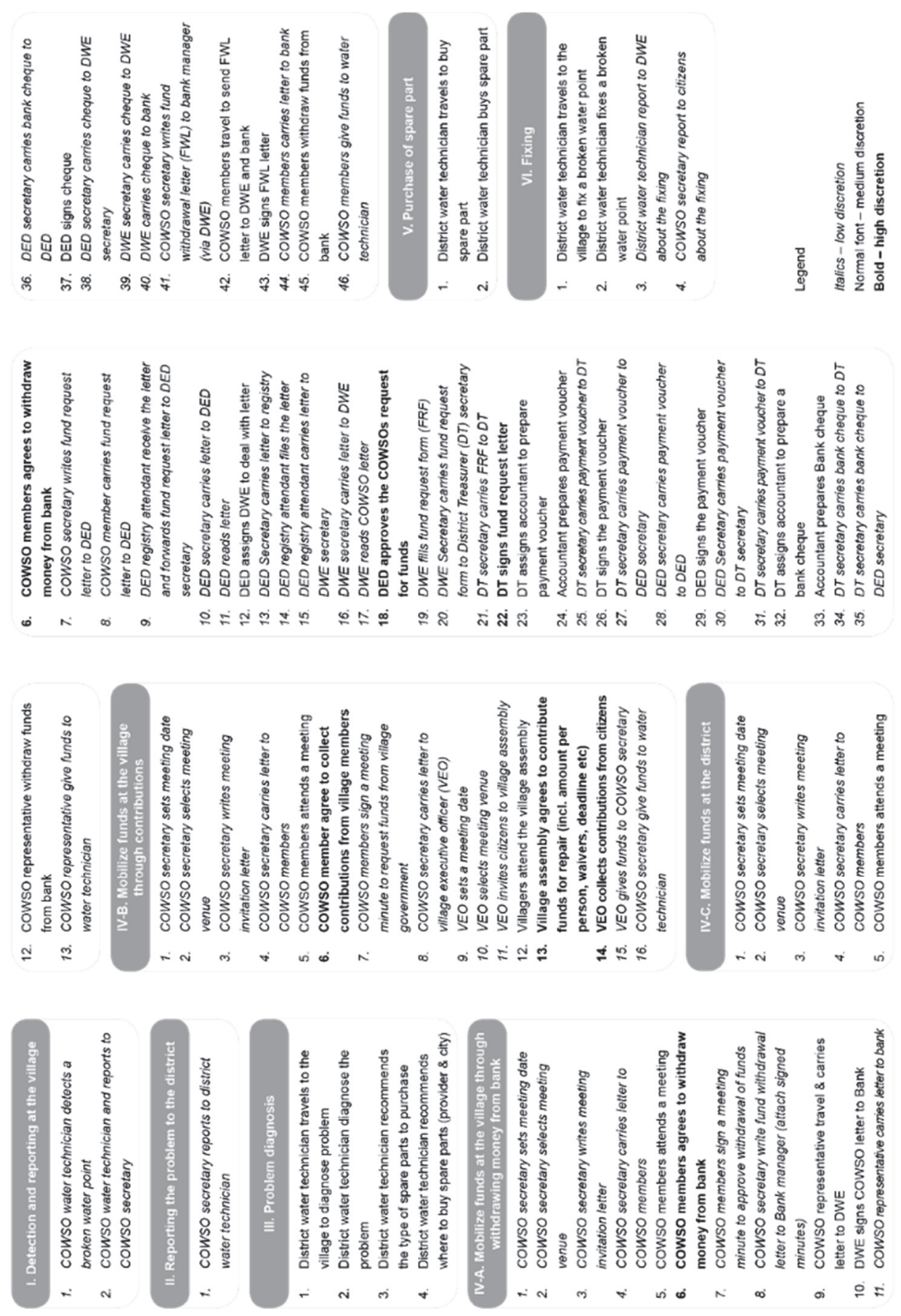

Figure 7.7: Steps and tasks in the information flow 


\section{References}

Ball, M., Rahman, Z., Champanis, M., Rivett, U., \& Khush, R. (2013). Mobile data tools for improving information flow in WASH: Lessons from three field pilots. Bristol, UK: Aquatest Research Programme, University of Bristol.

Booth, D. (2012). Working with the Grain and Swimming against the Tide. Public Management Review, 14(2), 163-180. doi: 10.1080/14719037.2012.657959

Braa, J., \& Hedberg, C. (2002). The Struggle for District-Based Health Information Systems in South Africa. The Information Society, 18(2), 113127. doi: 10.1080/01972240290075048

British High Commission Dar es Salaam. (2017). Government of Tanzania launches a nationwide scheme to improve access to water. https://www.gov.uk/government/world-location-news/government-oftanzania-launches-a-nationwide-scheme-to-improve-access-to-water

DFID. (2015). Phase 2: Rural Water Supply and Sanitation Programme, Tanzania: Annual Review: Department for International Development.

Fox, J. A. (2015). Social Accountability: What Does the Evidence Really Say? World Development, 72, 346-361. doi: http://dx.doi.org/10.1016/j.worlddev.2015.03.011

Fung, A., Gilman, H. R., \& Shkabatur, J. (2013). Six Models for the Internet plus Politics. International Studies Review, 15(1), 30-47. doi: 10.1111/misr. 12028

Georgiadou, Y., Bana, B., Becht, R., Hoppe, R., Ikingura, J., Kraak, M.-J., Lance, K., Lemmens, R., Lungo, J. H., McCall, M., Miscione, G., \& Verplanke, J. (2011). Sensors, empowerment, and accountability: a Digital Earth view from East Africa. International Journal of Digital Earth, 4(4), 285-304. doi: 10.1080/17538947.2011.585184

Georgiadou, Y., Verplanke, J., Lungo, J., \& Mbise, M. (2016). Water point mapping in Tanzania: Making the voices of data collectors audible. Paper presented at the 7th Rural water supply network (RWSN) forum: Water for everyone, 29 November - 2 December 2016,, Abidjan, Côte d'Ivoire.

Giné, R., \& Pérez-Foguet, A. (2008). Sustainability assessment of national rural water supply program in Tanzania. Natural Resources Forum, 32(4), 327342. doi: $10.1111 / j .1477-8947.2008 .00213 . x$

Hutchings, M. T., Dev, A., Palaniappan, M., Srinivasan, V., Ramanathan, N., \& Taylor, J. (2012). Mobile Phone Applications for the Water, Sanitation, and Hygiene (WASH) Sector. Los Angeles, California: Pacific Institute.

Hydén, G. (1980). Beyond Ujamaa in Tanzania: underdevelopment and an uncaptured peasantry, London. Berkerly and Los Angels: University of California Press.

International Energy Agency. (2011). World Energy Outlook 2011. Paris, France: International Energy Agency. 
Janus, H., \& Keijzer, N. (2015). Big Results Now? Emerging Lessons from a Result-Based Aid in Tanzania Discussion Paper 4/2015. Bonn, Germany: Deutsches Institut für Entwicklungspolitik (German Development Institute).

Jiménez, A., \& Pérez-Foguet, A. (2010). Challenges for Water Governance in Rural Water Supply: Lessons Learned from Tanzania. International Journal of Water Resources Development, 26(2), 235-248. doi: 10.1080/07900621003775763

Jiménez, A., \& Pérez-Foguet, A. (2011). The relationship between technology and functionality of rural water points: evidence from Tanzania. Water Science and Technology, 63(5), 948-955. doi: 10.2166/wst.2011.274

Jonoski, A., Alfonso, L., Almoradie, A., Popescu, I., van Andel, S. J., \& Vojinovic, Z. (2012). Mobile Phone Applications in The Water Domain. Environmental Engineering and Management Journal, 11(5), 919-930.

Kelsall, T. (2011). Going with the Grain in African Development? Development Policy Review, 29, s223-s251. doi: 10.1111/j.1467-7679.2011.00527.x

Levy, B. (2014b). Working with the Grain: Integrating Governance and Growth in Development Strategies. New York: Oxford University Press.

Mayo, A. W., \& Nkiwane, L. (2013). The role of community participation on cost recovery and sustainability of rural water supply projects in Hai District, Tanzania. Journal of Environmental Science and Water Resources, 2(11), 388 - 395.

Mulqueen, T. (2009). The Politics of Getting By: Understanding Political Stability in Tanzania. Brookyling College Undergraduate Research Journal, 1 .

Pritchett, L., \& Woolcock, M. (2004). Solutions When the Solution is the Problem: Arraying the Disarray in Development. World Development, 32(2), 191-212. doi: 10.1016/j.worlddev.2003.08.009

Pritchett, L., Woolcock, M., \& Andrews, M. (2010). Capability Traps? The Mechanisms of Persistent Implementation Failure Working Paper 234. Washington, DC: Center for Global Development.

Rottenburg, R. (2009). Far-fetched facts. A parable of development and humanitarian aid (A. Brown \& T. Lampert, Trans.). Cambridge, Massachusetts \& London, England: The MIT Press.

Scott, J. C. (2008). Professor James Scott's Lecture Transcript. Glasgow: Glasgow Centre for Population Health, University of Glasgow.

Srivastava, V., \& Larizza, M. (2013). Working with the grain for reforming the public service: A live example from Sierra Leone. International Review of Administrative Sciences, 79(3), 458-485. doi: $10.1177 / 0020852313491513$

Suchman, L. (1995). Making work visible. Commun. ACM, 38(9), 56-64. doi: $10.1145 / 223248.223263$ 
Therkildsen, O. (1988). Watering White Elephants: Lessons from DonorFunded Planning and Implementation of Rural Water Supplies in Tanzania. Uppsala: Scandinavian Institute of African Studies.

UNICEF/WHO. (2015a). Progress on Sanitation and Drinking Water: 2015 Update and MDG Assessment. Geneva: UNICEF and the World Health Organization.

United Republic of Tanzania. (2002b). National Water Policy 2002. Dar es Salaam, Tanzania.

United Republic of Tanzania. (2006). Water Sector Development Programme (2005-2025) Consolidated Report. Dar es Salaam, Tanzania: Ministry of Water.

United republic of Tanzania. (2013c). The water sector status report 2013. Dar es Salaam, Tanzania: Ministry of Water.

United Republic of Tanzania. (2015b). Tanzania Development Vision 2015: Big Results Now: 2013/2014 Annual Report. Dar es Salaam, Tanzania: President's Delivery Bureau.

Wacquant, L. (2005). Habitus. In J. Becket \& Z. Milan (Eds.), International Encyclopedia of Economic Sociology (pp. 315-321). London: Routledge.

Welle, K., Williams, J., \& Pearce, J. (2016). ICTs Help Citizens Voice Concerns over Water - Or Do They? IDS Bulletin, 47(1), 41-51. doi: http://dx.doi.org/10.19088/1968-2016.105

World Bank. (2014). World development report 2015: Mind and Society, Behavior. Retrieved 19 October, 2014, from http://go.worldbank.org/HYR6FHEK60

World Bank. (2015). Mobile cellular subscriptions (per 100 people). Retrieved 13 March 2016, from http://data.worldbank.org/indicator/IT.CEL.SETS.P2

World Bank. (2016). World Development Report 2016: Digital Dividends. NewYork, USA: The World Bank. 
Chapter 8

Epilogue - Working with the community grain in Kilimanjaro 


\section{Introduction}

This epilogue summarizes my findings of a study of a community-based management model for rural water supply that succeeded because it "worked with the grain" of existing informal and socially-embedded institutions. The empirical setting comprises two districts-Hai and Siha-located on the western slopes of mountain Kilimanjaro in the north of Tanzania. I was encouraged by water and sanitation experts in Dar es Salaam to study the water supply in these two districts after I presented to them my rather pessimistic findings in Mashujaa in January 2015. Understanding how community-managed institutions are formed, operate and survive is crucial given the increasing interest in making citizens take more responsibility of the water projects.

\subsection{Community-managed rural water supply - still the leading paradigm?}

Community-managed water supply has become the prevalent response to lack of sustainable access to water in rural areas of developing countries (P. Hutchings et al., 2015). Introduced in the early 1980s, the approach replaced government-provided water supply that had largely failed to improve water service delivery in many developing countries. Community-managed water supply appeals to principles of demand-responsive service delivery, community involvement, cost recovery and ownership. It is believed to improve the management, operation and maintenance of rural water projects and reduce the high rates of non-use, breakdown, and misuse that have plagued water supply projects in developing countries.

In Tanzania, community-managed rural water supply was officially introduced in the National Water Policy of 1991 to increase citizens' access to safe and clean water in rural areas. Governments, donors, researchers and development practitioners endorsed the community model enthusiastically. In 2002 the country adopted community-managed water supply for rural water projects to enhance efficiency and effectiveness. The policy gives citizens full responsibility for the design, construction, operation and maintenance of rural water projects (United Republic of Tanzania, 2002b). Still, nearly half of rural water points are not functional (United republic of Tanzania, 2013c) and about 20\% of newly constructed water points become non-functional within one year (Welle \& Williams, 2014). Currently, around 70 per cent of 44 million Tanzanians live in rural areas, while the population increases by 1.2 million people every year, one of the fastest growth rates in the world (UNDP, 2014). What is more, an increasing number of Tanzanians in rural areas are compelled to resort to traditional, unimproved water sources (ponds and streams), thereby endangering their health and well-being (UNICEF/WHO, 2015a). As we have seen in Chapters 6 and 7, community management is not producing the anticipated results in Mashujaa, and in several equally poor districts in Tanzania. The latest reported percentage of functional water points in 
Mashujaa district is 35 percent while Hai and Siha districts have a water point functionality of around 90 percent.

\subsection{Critiques to community management of rural water supply - working with the grain}

Scholars and development practitioners are expressing their concerns regarding the effectiveness of the model and note that building upon grassroots institutions as a way forward to improve rural water supply, e.g. Sun et al. (2010). Ellie Chowns' PhD research in Malawi is a case in point (Chowns, 2014). Malawi faces problems with the leading paradigm of community-managed water supply that are very similar to Tanzania's rural water woes. Chown's (2015) study of community-managed water supply in four districts of Malawi shows that both technical and financial performance under community management is weak. The maintenance of rural water points is rarely done, repairs are slow and sub-standard, and water user committees (the Malawian version of COWSOs) are unable to collect and save funds. She argues convincingly that "community management has 'worked' for the state (and donors) as a means of offloading responsibility for public service provision" ( $p$. 263) and not for water users for whom community management is the least preferred management option. Chowns (2015) concludes that "community management endures [...] because it enables [the state and donors] to abdicate long-term responsibility for service provision" (p. 272). The usefulness of the community management model to these actors was evident throughout my fieldwork in Tanzania. Water officials at central and district levels explain the problems in Tanzanian rural water supply sector by blaming the "lack of local ownership" by the communities, the apathy and lack of agency of rural citizens or their ignorance of their formal roles responsibilities (See Chapter 6). Similarly to Chowns' findings in Malawi, the preferred solution for the Ministry of Water to the "lack of local ownership" problem in rural Tanzania is more training so that rural citizens can "fulfil their responsibilities" under community management. This is unfortunate because for those on the ground, such as district staff the core problem is lack of funding for their support and supervision functions while users highlight problems such as frequent breakdowns, long repair times and unaffordable costs. Whoever frames the problem, frames the solution.

However, a wholesale rejection of the community-based management model is counter-productive. "Working with the grain" of existing informal, sociallyembedded institutions (Kelsall, 2008; Levy, 2014b) may have potential as an alternative framework. For instance, in Mashujaa, the Elderly-men for Development Association of Mwembeni (EDAM) and the Mwembeni diaspora (See Chapter 6) could be harnessed more sustainably to improve water point 
management or incentives could be considered to increase the political salience of water supply beyond election periods (Chowns, 2015).

\subsection{The grain of community management in rural water supply in Kilimanjaro}

In his inaugural contribution to the Africa Power and Politics Program (APPP), Kelsall (2008) asked "what might African development with the grain look like?" He argued that informal African institutions in which mutual accountability is strong can provide clues as to the shape of development with the grain. These institutions include the extended African family and ethnic groupings (tribes) which place a high value on celebrating basic life-cycle rituals, such as births, initiations, marriages, and deaths, mutual financial help and the resolution of conflicts within the extended family or tribe and not by appealing to formal state agencies. Other effective institutions are churches and mosques which enjoy so much popular support that they are often financially self-sustaining. They are heavily involved in providing local education, water, and health, services, whose quality surpasses those provided by the state. In sum, "many Africans do not first and foremost think of themselves as individuals; they think of themselves as members of limited extended families (extended families that may extend before birth and after death). Beyond that they identify, in concentric circles of weakening moral obligation, with wider extended families, clans, ethnic groups, and only then, if at all, with the nation state." (p. 18, emphasis added). In general, the rules and procedures of Western institutions sit ill with African traditions.

Inspired by Kelsall's "working with the grain" approach, I followed the advice of the water and sanitation experts in Dar es Salaam. I set out in the spring of 2015 to understand how community-managed institutions are formed, operate, survive, and even flourish, in Kilimanjaro. I felt that such a study is crucial given the increasing interest in making citizens to take responsibility of the water projects.

\subsubsection{Empirical setting and methods}

The Hai and Siha Districts on the western slopes of mountain Kilimanjaro belong administratively to the Kilimanjaro region, which comprises a total of seven districts. Hai and Siha have populations of 210,533 and 116,313 respectively (National Bureau of Statistics, 2013). Their capitals are the small towns of Bomang'ombe and Sanya Juu in Hai and Siha respectively. Chama cha Maendeleo (CHADEMA), the main opposition party, has a majority in both districts, with two members of parliament coming from the same party. The Chagga and the Maasai are the dominant tribes. They practice mixed farming, growing mainly coffee and bananas, but also maize, beans, finger millet, peas, 
sweet potatoes and yams. Zero grazing is predominant in the coffee and banana belt whereas open grazing is common in the lower plains.

The water projects in the two districts date back to the early 1990s when a few community members from Hai organized themselves through the Evangelical Lutheran Church of Tanzania Northern Diocese (ELCT-ND) and initiated the first community water project at Uroki village and its neighbouring villages. To secure funding, the Church wrote a project proposal and presented it successfully to their sister Lutheran Church in Germany. Since then the projects have expanded continuously both in terms of water infrastructure and served population. The Steering Committee of the first project comprised the Kilimanjaro Regional Commissioner (chair) and the Bishop of the Evangelical Lutheran church in Tanzania - Northern Diocese, Dr. Erasto N. Kweka (cochair). The Steering Committee Secretary was the District water Engineer for Hai. Other committee members were representatives of central Government, Hai district authorities and religious institutions in the project area.

In the Spring of 2015, I conducted in-depth interviews with eleven citizens, eight Village Water Committee (VWC) members, six technical staff of two rural water projects-Uroki-Bomang'ombe and Lawate-Fuka-and two district officials in both districts to understand how citizens access water service and their involvement in the design, construction and management of community water projects. I interviewed two officials of the Water Service Facility (WSF), an independent organization providing technical and advisory support to community water projects, to understand day-to-day operations in dealing with representatives of community water projects as well as government officials in Hai and Siha districts.

I accompanied district officials and facilitators from the Water Service Facility to observe the election of water committee members in two villages (Kishisha and Mae) as well as the election of ward representatives to the Board of Trustees for Lyamungo-Umbwe Water Trust. During these elections, I captured how citizens in practice define the criteria for selecting village water committees and water boards, the "best suited" people for representing their interests in monitoring rural water supply. I observed how facilitators communicate with citizens on the objectives of the elections, water committees and the board of trustees. Lastly, I observed the way district officials oversee and support citizens to actually elect their representatives.

\subsubsection{Informal institutions for water management in Kilimanjaro}

The two prevalent informal institutions in Kilimanjaro are the Chagga tribe (including the Chagga diaspora) and the Evangelical Lutheran Church. 
The Chagga people have evolved over some five centuries a singularly homogenous culture, without ever achieving a political unity (Werner, 1924, p. 363).

"The Chagga are one of the most highly educated people in Tanzania, with over 80 percent literacy in the 1980s. During the colonial period, Chagga welcomed missionaries and the majority of them are Christian. [...] As the most educated population of Tanzania, they exercise a great deal of influence in economics and politics and have the highest number of people in government, education, and the arts." (Shoup, 2011, p. 69).

The Chagga are famous for their successful community water system management (Grove, 1993). Sir Harry Johnston, who led an expedition to Kilimanjaro in the early 1880's, "reported that there was scarcely a ridge without its own irrigation channel. He marveled at the skill with which the Chagga used tiny channels to irrigate the terraced hillsides and the time spent in turning the soil, manuring it with ashes and raking it with wooden hoe" (Grove, 1993, p. 431). The Chagga have successfully managed traditional irrigation furrows on the slopes of Mount Kilimanjaro in order to cultivate coffee and bananas among other crops throughout the year and thereby withstand drought. Furrow management is intimately linked to agricultural development and increased food security in the region. While irrigation furrows have become less dominant due to the shift to piped water supply, the history and experience in community-based furrow and water management has created a tradition of community participation and self-help (Döring et al., 2007). "The successes in managing traditional furrows did not come overnight. Our ancestors experienced a lot of water use conflicts. The Chagga tribe's collective action was not by design, but a realization that conflicts caused by water use could only be solved by working together for the benefit of all people," clarifies an old man in Uroki village. These long-practiced behavioural attitude created a solid foundation for the involvement of citizens in the design, implementation and management of rural water supply in Hai and Siha districts. Another longstanding tradition of the Chagga tribe is sanctioning those who abuse irrigation furrows:

"For minor offenses, such as washing in a furrow, the culprit is warned informally by a neighbour or more publicly at a ten-cell meeting. [...] If the offense is repeated the neighbours can decide on a punishment such as cleaning the furrow or brewing banana beer for them all. More serious cases were dealt with by the village council. [...] ... urinating in a furrow would be punished by the elders slaughtering a cow belonging to the offender and cooking and eating it where it had been killed" (Grove, 1993, p. 440). 
The Kilimanjaro region is a strong hold of Christianity. "When the Gospel message was brought for the first time to the Chagga people of Moshi in 1880s, it was received with enthusiasm to the extent that the people of Moshi were nicknamed by the non-Chagga as the community of "Yesu, Maria na Yosefu" meaning the community of Jesus, Mary and Joseph" (Mafikiri, 2010, p. 2). In 1952, during the first anniversary of Thomas Marealle's election as the "Mangi Mkuu", "The Paramount Chief" of Chagga, Bender (2013) writes that "the celebration started with prayer services held at the Catholic and Lutheran churches, followed by a ceremony attended by major local dignitaries." ( $p$. 199). Seeking God's blessings in public functions is long-established among the Chagga people. Most official activities are preceded by prayers. For instance, the election of Water Boards (which were attended by district officials and facilitators from the WSF) in the two villages I visited began with prayers by the pastors.

Some of the Chagga chiefdoms benefited from the invasion of the German colonialists. Chagga chiefdoms were implicated in frequent wars and rivalry fuelled by a struggle for power and natural resources. To access ammunition, some Chagga chiefs tactically allied themselves with colonialists to fight other Chagga adversarial chiefdoms. In 1891, Winsmann, a German colonialist, invaded Kibosho with 300 soldiers and 400 auxiliaries supplied by Rindi, the chief of Machame (Iliffe, 1979, p. 100). The influence and impact of the Evangelical Lutheran Church in Tanzania (ELCT) extends beyond the Chagga and includes almost the whole country. Upon Tanzania's independence in 1961, some of the country's leaders claimed that the Evangelical Lutheran Church "had made an important contribution in preparing the people of Tanganyika for its independence" (Ludwig, 1999, p. 41).

At the time of first project implementation, Bishop Erasto Kweka was heading the Northern Diocese of the Evangelical Lutheran Church in Tanzania. Common citizens, politicians, government officials as well as influential people within and outside the region revere Bishop Erasto Kweka (now retired) for his instrumental role in securing funds from the German Lutheran Church and for successfully implementing the first water project. Bishop Kweka is still considered to be one of the important religious leaders in the region. Unfortunately, my attempts to meet him were not successful. "He is very old but has a very tight schedule. Many people visit his home for interviews or seeking advice," explained the head of WSF.

The Chagga diaspora plays an important role in water supply in Hai and Siha districts, but indirectly, by facilitating their parents and relatives financially to acquire a house water connection: "I just wanted to relieve my mother from the burden of carrying a bucket of water from the public water point a few meters from home. I am happy that my mother can access water at her own 
homestead" (Citizen, Hai district). Likewise, the Chagga diaspora supports their parents and relatives in paying their water bills. An interview with the accountant for Bomang'ombe Water Board revealed that they receive lumpsum advance payments from people living in urban centres on behalf of their parents or relatives in the villages.

\subsection{Community rural water projects in Hai and Siha districts}

Water supply in Hai and Siha has changed over the years in terms of modality and scale. In the early days, water was distributed through stand pipes only. After the first water project was completed, most citizens accessed water through public stand pipes. Only a few had house connections. Currently, the majority accesses water through house connections, due to the expansion of the original projects and advancements in housing styles (indoor western cisterns and bathrooms) and citizens' increased capacity to finance house water connections. Thus, most public stand pipes have become commercially non-viable and are being closed down. The scale of the water distribution network has increased significantly since the 1990s. In 2013 alone, the distribution network for Uroki-Bomang'ombe and Lawate-Fuka Water Boards increased by $122 \mathrm{~km}$ and $12.75 \mathrm{~km}$ respectively. The first project has now expanded both in terms of infrastructure and served population. The water projects of Hai, Siha and part of Moshi rural districts are estimated to serve a population of about four hundred thousand people. The Water Service Facility reports that the current water supply coverage in Hai and Siha districts is $92 \%$, one of the highest in the country, while the national average water coverage is estimated at $45 \%$ (source).

Currently the water projects have expanded such that they also serve small towns such as Bomang'ombe and Sanya juu, the administrative capitals for Hai and Siha districts respectively, as well as Kilimanjaro International Airport and its surroundings.

\subsubsection{Formal management institutions}

Each water project is managed by the following formal institutions:

The Board of Trustees (BoT) is the supreme decision making body entrusted with planning and policy making functions. It is responsible for directing, managing and supervising the management team that carries out the day-today functions of the water trust. The Board of Trustees is formed by representatives of village water committees from the project area, and the District Water Engineer (DWE). A pamphlet on the role and responsibilities of the BoTs reads "board of trustees has been chosen on the principles of trust; members of the board of trustees are entrusted to sustain, safeguard, operate and maintain the water project on behalf of the stakeholders or beneficiaries" 
(Water Service Facility, 2014). BoTs appoint and employ the Management Team and own all water project properties on behalf of the Government of Tanzania. The BoTs meet at least three times a year. The first Board of Trustees was formed in 1996 for the Uroki-Bomang'ombe Water Trust.

The Constitution of the Board of Trustees for each Water Trust spells out the conditions for membership in the form of a list of nine conditions stated in prohibitive form. For instance, the Constitution states that "nobody will be elected as a member of the board of trustees, if..." (Board of Trustees Constitution, 2014), i) s/he is not above 30 years, ii) s/he did not finish form four (ordinary secondary education), iii) $\mathrm{s} /$ he is not a resident in the project area, and iv) is a village chairperson in the project area. The conditions limit politicians and poor performing members in previous boards from becoming members. Citizens with full time "salaried" employment are not eligible to become members of the board of trustees. Common examples of such employees in the villages are public employees, such as teachers, health workers and village executive officers.

During elections of board members, candidates must state their age, education, occupation and residence. And if they forget to mention one of the four conditions, the audience reminds them and demands such information. One of the Water Service Facility staff justifies the need for setting high demands on these conditions, particularly on education:

"Education is a very important aspect for the board members, especially the chairperson. Given that most of the managers are graduates, you need a board chairperson who can narrow the education gap. You need someone who can understand the language of graduates [managers] as well as a person who is able to scrutinize them" (Facilitator, WSF).

In practice, these conditions are not always easy to implement. For instance, the district council had to nullify the election of a member of board of trustees on grounds that he did not have the required education qualifications - a form four education. It appeared that this individual had secondary education, but was a dropout (dropped at form two, halfway before graduation). The district council's justification for nullifying the results was fear to set a bad precedent:

"I am not sure who made these guidelines, however, I believe they were made in good faith. I am not worried about that, my only concern is that we should abide by the guidelines. If we feel that we set very high requirements, we should resolve this in the next elections. If we do this now, then we shall be in trouble. My worry is that if we lower the requirements just for this guy [election winner], then we should 
expect to receive letters from other contestants from other villagers complaining about double standards. I suggest we nullify his membership to the board of trustees" (District Official, Siha).

While the constitution does not talk about equal representation of women in the board of trustees, there are efforts to increase it. The water boards have realized that existing conditions for membership requiring board members to be elected from chairpersons of village water committees disfavours the women. As a result, all board members for the Uroki-Bomang'ombe Water Supply Trust are men. "It is not our desire not to have a woman in the board, however, there was no female chairperson of a village water committee" says the Manager, Uroki-Bomang'ombe Water Supply Trust.

All Water Boards have their own buildings as main offices housing the management team and equipment, such as spare parts. Water Boards also have sub-offices located in villages. No permanent staff is working at the suboffices, however, staff from the main offices use these offices when they travel to and work in the villages. The sub-offices were built in order to bring the project staff closer to citizens and are currently used for bill payment purposes on selected days of the week.

The Management Team (MT) consists of professionals carrying out the day-today operation and maintenance of the Water Trusts. The MT is headed by the Manager, who often has an engineering background. Other staff in the MT include an accountant and cashier, a chief of technical staff and water technicians, as well as supporting staff such as office attendants, security guards and janitors. All the MT staff draw regular salaries from the water trusts i.e. from collection fees.

The Village Water Committee (VWC) has ten members from each village within the project. Chairpersons of the Village Water Committees automatically become members of the Board of Trustees. Given the growing number of villages within a project, which makes a board of trustees to have many members, the selection of water boards is going to change. "It has become too expensive to run these water boards, particularly in financing their meetings" says the Manager for Lawate-Fuka Water Trust.

The Village Water Committee oversees the quality of water supply in the village and ensures the timely payment of water fees. "Every month we receive a list of users who have not paid their bills and we visit them so that they tell us why and when they are going to pay the bills" says one of the village water committees at Soni village, Uroki-Bomang'ombe Water Trust. 
Formal conditions of membership to the VWC are provided in the constitutions of water trusts. Similar to the membership conditions for the Board of Trustees, commonly mentioned qualifications include age, education, residence and occupation. Any citizen who is above 18 years is eligible to be a member of the VWC, but cannot be elected as chairperson unless $s /$ he is above 30 years. Speaking before the village, a WSF election facilitator defended the age limit for chairpersons, thus: "For the chairperson, we need someone who is above 30 years. It was 40 years but we reduced it to 30 . At 30 years, you are settled. We don't need people who are searching for green pastures, people who will migrate to other places in search for opportunities" (Election facilitator, WSF). The importance of having educated water committee members is emphasized. During the election of water committee members in Kishisha village, the facilitator defended the education requirements of the candidates citing that

"the advantage of having an educated chairperson is an effective representation at the Water Board of Trustees. The educated ones are very tricky nowadays, they write things in English. When a board member says 'let us go to page 2', then he or she should be able to understand and follow through. So if you have an educated person, then use him/her" (Election Facilitator, WSF).

While the Constitution of the Water Trusts does not distinguish between the qualifications of male and female members of the water committees, there is some leniency when electing female members, because it is difficult to find female candidates who meet the rigorous education qualifications set in the constitution. And if they exist, they are likely to have many other posts, which makes it difficult for them to accept additional roles, as water committee members.

While water committee members work on a voluntary basis, they are paid allowances when attending meetings. The sitting allowance is a form of incentive for water committee members. Given that most of the communication and decision making is done through face-to-face meetings, sitting allowances play an important role in day-to-day operation of village water committee members:

"There is huge and easy money there [Uroki-Bomangombe water trust (UBWT)]. If I organize a meeting at the village and submit the minutes at the office, I will get a hundred and twenty thousand shillings within ten minutes... I would say less than five minutes. They treat us [water committee members] very well, they don't want us to make any complaints" (VWC member, Uroki village). 
Water Point Agents (WPAs) run public stand pipes, sell water to users and receive a commission resulting from fee collections. Water Point Agents are paid a commission against revenue collection which ranges between $10 \%-$ $20 \%$ of the total revenue collected.

The District Council is involved (the state) in the water projects in Hai and Siha districts in two ways: i) in the design and implementation of the project, and ii) in post-construction of the projects. During the design and implementation of the project, particularly in Hai, the district council provided land for the water projects (WSF offices are located in public land). In addition, regional government was involved in the Steering Committee, formed to execute the first water project. The state has been instrumental in resolving conflicts and enforcing regulations. "The government helps us in enforcing rules and regulations. In most cases, the government helps us to deal with citizens who bring us problems. For instance, the government has been very instrumental in dealing with theft cases, resolving land conflicts, reluctance to contribute or pay water fees" remarks the head of WSF.

The Water Service Facility (WSF) supports and sustains Water Trusts. The WSF is a legally established organization under the Hai and Siha Districts Councils and cooperates with the independent existing water supply trusts as a nonprofit professional service provider facility. The vision of the Water Service Facility is "to make sure that the water supply trusts established during the project implementation are sustainable and can meet the requirement of supplying clean and safe drinking water to the targeted beneficiaries efficiently". The Water Service facility is run by a small team of full time professionals who provide technical and commercial support to the Water Trusts. In addition, WSF has a network of associates who work on short-term contractual basis when need arises. The WSF is headed by a manager supported by two departments i.e. technical and commercial departments. The Constitutions of all Water Trusts recognize the Water Service Facility as the provider of technical and advisory support: "We have a special arrangement with most manufacturers in Germany. We buy spare parts from them and we sell them to water trusts. WSF is exempted from paying taxes and thus we sell our spare parts at affordable prices. However, often prices are higher than the prices from local shops that sell poor quality spares imported from Asia" (WSF Official, Bomango'ombe).

The WSF is a unique organisation in the entire country. The Government of Tanzania is making strides to create similar institutions, called "Centres of Excellence", to address operation and maintenance of rural water projects in all Tanzanian districts. The Tanzania Big Results Now! Road Map - National Key Result Area Water 2013/14 - 2015/16, mentioned the creation of "Centres of Excellence" at district level in order to improve technical aspects of rural water 
supply (United Republic of Tanzania, 2013a). However, the initiative is yet to become operational.

The Water Service Facility (WSF) depends much on the willingness of the Water Trusts to seek its services. Each Water Trust has signed a memorandum of understanding (MOU) with the WSF, which describes the terms and details of the partnership, including the obligation of the Trust to seek services from the WSF. The prices for service charged by the WSF are often higher than those from local private service providers, because the WSF orders high-quality spare parts from Germany. On rare occasions, water trust members have tried to buy spare parts from local private distributors, reportedly lured by personal benefit.

\subsubsection{Performance of the Water Trusts}

The commitment of the Water Trusts in Hai and Siha districts to fulfil customer demands is evident in the mission of the Uroki-Bomang'ombe Water Trust (UBWS): "To supply clean and safe drinking water, twenty four hours in a day, three hundred and sixty five days in a year, for at least next fifty years at affordable costs" (Constitution, Uroki-Bomang'ombe Water Trust). The mission statement includes aspects of affordability, convenience, quality and reliability. The supply of water on $24 / 7$ basis is true only for house connections. Public stand pipes do not supply water at night, because the water seller is not available at night. However, all citizens are aware when to expect water at the public stand pipes. Each stand pipe has a sign post that shows the timetable for citizens to collect water. Hence, even in this case the provision of water through public stand pipes does not take away reliability. Most importantly, citizens who are using the public stand pipes have an option to choose a higher level of service - a house connection that provides water on 24/7 basis.

\section{Financial performance}

The need to sustain the water projects, forced the water trusts to introduce water fees early on, which at that time were against national water policies that advocated for "free water for all". This surprising initiative was instituted incrementally. First, the original church-initiated water project instituted a department specifically to create awareness among citizens and public officials on the importance of paying for water. Secondly, the project created conducive conditions both for the Water Trust and the citizens to transition well from a "free water" policy to a policy of "water as a commercial good". The project paid salaries and all running costs of the Water Trusts for a given period (six months for Uroki-Bomang'ombe water trust) to allow them to get on their feet. Likewise, the project offered a discounted price to citizens who wanted to acquire water connections: "All water trusts had a fund for the transition period which was spent for running the offices including paying salaries to staff for a period of up to six months. The money came from the customers - we offered 
a discount on connection fees for a given number of first customers" (WSF Staff, Bomang'ombe). The project realized that, if citizens were to afford the services, then there must be a discounted price of water connection costs.

All Water Trusts in Hai and Siha districts are committed to collect water fees and the billing collection efficiency is high. Each Trust has a trained accountant, often with supporting staff such as cashiers. All customers have water meters and pay on a monthly basis for the consumed water. The collection of fees is followed up by the Village Water Committees. The Water Boards particularly accountants print out a list of water users who have not paid their bills (14 days after having received the water bill) and send it to the Village Water Committee for follow-up. The Water Trusts have been using an electronic billing system since 2006 (compare with Mashujaa town and its ill-fated electronic billing system in Chapter 5) and hence accountants can print a list of nonpaying customers just by pressing a button. Water committees are responsible to make sure all customers pay their water bills. This is done in various ways including physical visits of the members of the water committee to the houses of water users to remind them of their debts, collecting fees or finding out reasons for non-payment. As mentioned earlier, in order to facilitate the collection of water fees, water trusts have constructed sub-offices in the villages. The sub-offices bring the water trust staff closer to citizens and are used for bill payment purposes on selected days of the week.

Limiting the amount of non-revenue water is one of the priorities for all Water Trusts in the two districts. All points of abstraction are metered to enable customers pay according to consumption: "We have decided to put water meters at the point where the customers pipes starts" says Eng. Marandu. "We put the water meter outside the fence of the water user which makes it easy to notice any illegal connections," comments a water technician for UrokiBomang'ombe Water Supply Trust.

The primary strategy to ensure sustainability of the water infrastructure is the institution of the so-called "rehabilitation funds". Water Trusts must keep aside funds (in a separate bank account) that can be used to replace infrastructure broken after ten years of operation. Normally, "the agreement is that the district council covers all the investment and maintenance costs for infrastructure that has a life span of more than ten years" says the District Water Engineer for Siha district. However, Water Trusts, particularly those who have attained financial independence, keep aside part of their water fees as "depreciation funds":

"When the government promised to replace long-term infrastructure [life span of more than 10 years], we stopped setting aside money for depreciation almost a whole year. However, the experience with the 
pipes [district council failed to give funds for replacing broken pipes] taught us a lesson, we have resumed to our old system. We now keep money for the depreciation." (Manager, Lawate-Fuka Water Trust).

A secondary strategy to ensure sustainability of the water infrastructure is to protect depreciation funds from being spent for other purposes than water. It should be noted that Water Trusts are constantly receiving demands from district councils to allocate depreciation funds to other purposes. "Some of the councillors have questioned the funds for depreciation of the water infrastructure. They argue that such funds are huge and they can be used by the district council to funds other things [including non-water issues]. They are not happy when they see that a water trust has an account that has about two hundred million shillings just lying around. Even if they might have a point, we don't think that they would spend the money responsibly" says the Manager for Lawate-Fuka Water Supply Trust.

\section{Institutional performance}

I already discussed the high professional and educational standards to which managerial and technical staff has to comply with and earn their salaries as part of the income from water fees: "All people working for the water trust are well-off. Even water technicians have very good houses. You cannot find a water technician who does not have a good house" says the village chairperson for Mamba village (served by Uroki-Bomang'ombe Water Trust). Eng. Marandu has dubbed the water trusts money making machines. "These are money making machines. There is no much cost in running the water trusts" he says. The tidiness and labelling of all infrastructural parts is impressive, the operation and maintenance of the water supply system follows engineering manuals for operation and maintenance, all storage tanks and pressure reducing tanks are well-fenced and protected by permanent gates against vandalism and sabotage.

A system of rewarding excellent performance is organized by WSF in collaboration with the Board of Trustees from each Water Trust. Each Water Trust is evaluated based on the following criteria: i) the operation and maintenance of the water supply system, ii) financial management, iii) quality of service, and iv) water sources protection and conservation. The appraisals are carried out in the form of a competition among the Water Trusts and the winners are awarded with a trophy, a certificate and prize money. The first winner receives a trophy, a certificate and two million shillings. The first runner-up gets one and a half million shillings while the second runner up gets one million shillings. "The money can be spend as per Board of Trustees' decision. For instance, they may wish to give it to their well performing staff or organize a big party for their staff" commented the head of WSF. 
Water Trusts spend significant amounts of their resources, particularly time and money, to participate in the performance appraisals. The process is very long and each cycle takes about nine months: "We begin in July and the last report is printed on March or April the next year. It is very intensive work. We visit every connection, every water tank," explains one of the WSF staff. These annual performance appraisals have contributed to the improvement of service delivery. "People need to be motivated by something. Don't think that all what you see here comes automatically. The performance appraisals push the water trusts to excel," he comments. One appraisal report for the Lawate-Fuka Water Trust reads "toilet paper holder was missing at the watchmen toilets". Such a high level of detailing is not common practice in rural water projects in Tanzania.

\subsection{Interplay between formal and informal institutions}

The interplay between informal and formal institutions has a productive effect on rural water supply. Citizens and public officials (including Water Trust staff) start with prayers and references to God when communicating formally. All weekly meetings between managers of the Water Trusts and the Water Service Facility begin with a prayer - seeking God's guidance in reaching at decisions that are beneficial to all citizens (author's observation in the meeting) and are called "morning prayers".

Religious platforms, such as churches and mosques, are used systematically in reaching out to citizens. Interviews with Water Service Facility staff, as well as staff at the Regional Water Secretariat, revealed how instrumental religious platforms were in creating citizens' awareness about the water projects particularly on the need to pay water fees. Notably, the water projects in Hai and Siha districts began when the National Water Policy on rural water supply was still under free-service principles. "We began charging for water when the law of the country said water is free. It was not an easy job, but we managed to convince citizens to pay water fees," comments one of the Water Service Facility staff. "Initially, we could not get enough people to attend meetings [through village governments]. When we realized that people trusted their religious leaders more, we felt it would be a good idea to channel our messages through them [religious leaders]. And when we implemented the idea, we got positive results. Citizens started to show interest in the project," explains a public official at the water section, Kilimanjaro Regional Administrative Secretariat, who has been involved with the water projects in Hai and Siha districts since their inception.

The teaching materials for creating citizens' awareness on the project have religious underpinnings: "You need to frame the information according to the 
audience" comments one of the facilitators at the WSF. Comparing the teaching materials for primary schools, churches and mosques, it is easy to see how the head of WSF frames his teaching to fit the audience. "In the Quran, God mentioned the word "water' ninety times" is an opening line for the teaching materials for the Muslims [WSF head is Christian]. In his teaching materials to Christians, the opening line is: "Genesis 1:2 And the Spirit of the God moved upon the face of the waters" (my own emphasis). The great teaching skills of the head of WSF have contributed to the success of the project particularly the buy-in of citizens to pay for water.

The solidarity of the Chagga diaspora with their relatives has played a significant role in improving water fee collection in the two districts: "Most people especially pay their bills in advance [prepaid] because it is their children or relatives living outside these are who pay for water" underscores the Head of Commercial Department at WSF. The Chagga of the diaspora visit their ancentral homes in Kilimanjaro during Christmas, and at this time they pay a lump sum of money to water supply trusts to cover the water bills of their parents and relatives for the next couple of months: "Some [Chagga diaspora] have houses in the village but they live in urban centres. Their houses are connected with water, however, only consumed for a short period of the year when the owner are visiting the village" says a water technician for UrokiBomang'ombe water Supply Trust.

While Village Water Committees are responsible in making sure all water users pay their water bills, it may happen that the water committee pays the bill themselves to avoid shame: "There was one public water tap attendant who did not pay a water bill and the water board wanted to disconnect water. We were concerned that people [who were paying money when collecting water at the tap] would miss out water, we collected money and paid the bill on his behalf. We then forced the attendant to pay us back" (Water committee member). The committee paid the money on behalf of the water tap attendant out of shame. "It would be a shame for the water board to disconnect water while people are paying their bills", he commented. Water committee members felt that delay of payment would suggest that they are poor and cannot afford to pay for water. Appearing destitute is highly discouraged among the Chagga.

Voluntarism is significant. When the first project implementation had commenced, citizens excavated trenches for laying water pipes, and participated in awareness-raising campaigns regarding the importance of paying for water and for environmental conservation. The involvement of citizens and their subsequent contributions of their labour and money did not develop automatically, but was largely influenced by religious leaders. "We tried to get people to come to meetings at no avail. Then something came to our mind, we realized that people don't miss their prayers. Then we decided to 
follow the people where they are, in churches and mosques" says the former District Water Engineer for Hai district. The political and administrative leaders within the targeted project area were educated in seminars. The Christian and Muslim religious leaders were educated in seminars. The beneficiaries were educated in general village meetings. Volunteering and accepting roles in water committees may have material benefits that come along when carrying out certain tasks. One of the water committees notes:

"there is huge and easy money [in Uroki-Bomangombe water trust (UBWT)]. If I organize a meeting at the village and submit the minutes at the office, I get a hundred and twenty thousand shillings within ten minutes... I would say less than five minutes. They treat us [water committee members] very well, they don't want us to make any complaints."

Most of the office bearers of the management team have had their posts for very long periods. Most of the technical staff come from the same area. They are mostly Chagga and they have been in the area for a large part of their life. Most of the Water Trust staff holds important leadership positions in the church. The accountant for Uroki-Bomang'ombe is the treasurer for the Evangelical church in his village.

The majority of Water Trust staff grows with the organization. Few opportunities exist for new entrants because Water Trusts recruit and develop their technical and professional positions over time. For instance, one of the current water technicians for Uroki-Bomang'ombe Water Trust joined the organization during its inception as a security guard:

"We would work all night creating treads of pipes. We were trained and they would pay us 1000Tshs for every pipe we treaded. I would tread five pipes per one night. It was a lot of money, we would not sleep, we worked all night. By then, the monthly salary was only 40,000Tshs [he worked for two jobs, as a security guard on a day and a plumber at night]"

In other words, the Water Trusts are not looking for suitable members to fill positions, but are creating positions over for existing members instead. Social background of the people working for the Water Trusts explain this phenomenon:

"I joined the Water Trust in 1995. I first worked as a secondment and later was fully employed by the Water Board. They approached me and they had a better offer in terms of money. And, I was fed up with teaching. I wanted to make a direct impact and felt that coming here 
was the best thing to do then. I come from this area and that might have contributed as a motivation to come this side" (Manager, UrokiBomang'ombe Water Trust).

This is very true for many others working for very long periods of time for the Water Trusts. Their names have become synonyms of the trusts they work for. Almost all the key personnel for Uroki-Bomang'ombe Water Trust have been with the organisation since its inception in the 1990s. "It's like they own the water trust" comments one citizen, a complaint from several citizens in the area. Those who have worked for the water projects for long periods feel that they are doing a right thing for the projects. "Being here for all these years I have reached a point where I feel that the project is like my son, and I wouldn't want to see my child dying" comments one of the long serving staff at the Water Service Facility.

\subsection{Comparing useful informality for sustainable rural water supply}

In this epilogue, I set out to understand how community-managed water supply was formed and operates in Kilimanjaro. While rural water supply in Mashujaa is limping along, it flourishes in the Hai and Siha districts. Recalling the organisational structures (programs, communication channels and members) from Chapter 6 , section 6.3.1, a comparison can be made between informality in Mashujaa and Hai \& Siha districts (Table 8.1).

The most significant difference between the two cases is in the "informal programs", the well-established, historically grounded, and socio-culturally embedded routines that dictate informal responsibilities and determine which of the members' actions are to be viewed as right or wrong, and rewarded or sanctioned. In terms of informal communication channels, it is worth noting the regularity of the Chagga diaspora versus the irregularity of the EDAM civic association in Mashujaa. It seems that the productive interplay between the various informal organisational structures in Hai and Siha with the formal structures is a necessary condition for the flourishing rural water supply in Kilimanjaro, but further research is needed. 
Table 8.1: Comparing useful informality for citizens

\begin{tabular}{|c|c|c|}
\hline & \multicolumn{2}{|c|}{ Useful informality for sustainable access to water } \\
\hline $\begin{array}{l}\text { Rural water } \\
\text { supply }\end{array}$ & $\begin{array}{ll}\text { Mashujaa } & \text { district } \\
(\text { Chapter 6) } & \\
\end{array}$ & Hai and Siha districts (Chapter 8) \\
\hline Informal Programs & N/A & $\begin{array}{l}\text { Tribal ethos of the Chagga - } \\
\text { emphasis on education, } \\
\text { professionalism in management, } \\
\text { abhorrence of destitution, } \\
\text { voluntarism } \\
\text { Religious ethos - paying for water, } \\
\text { a sacred resource } \\
\text { Tribal traditions in sanctioning } \\
\text { asocial behavior and rewarding } \\
\text { excellence } \\
\text { Bypassing the state (district } \\
\text { council) with own, protected } \\
\text { "rehabilitation funds" for water } \\
\text { infrastructure } \\
\text { Salaried management }\end{array}$ \\
\hline $\begin{array}{l}\text { Informal } \\
\text { Communication } \\
\text { channels }\end{array}$ & $\begin{array}{l}\text { Civic organization } \\
\text { (EDAM) irregularly } \\
\text { collects funds to repair } \\
\text { broken water points }\end{array}$ & $\begin{array}{l}\text { Chagga diaspora regularly paying } \\
\text { water bills of relatives }\end{array}$ \\
\hline Informal Members & $\begin{array}{l}\text { Mashujaa diaspora } \\
\text { One civic organization } \\
\text { (EDAM) }\end{array}$ & $\begin{array}{l}\text { Chagga diaspora } \\
\text { Christian and Islamic institutions } \\
\text { Chagga long-term personnel in } \\
\text { water trusts (a kind of family } \\
\text { business) that progresses through } \\
\text { the management ranks. }\end{array}$ \\
\hline
\end{tabular}




\section{References}

Bender, M. V. (2013). Being 'Chagga': Natural Resources, Political Activism, and Identity on Kilimanjaro. The Journal of African History, 54(2), 199220. doi: $10.1017 /$ s0021853713000273

Chowns, E. (2014). The political economy of community management: a study of factors influencing sustainability in malawi's rural water supply sector. (PhD thesis), University of Birmingham, Birmingham, UK.

Chowns, E. (2015). Is Community Management an Efficient and Effective Model of Public Service Delivery? Lessons from the Rural Water Supply Sector in Malawi. Public Administration and Development, 35(4), 263-276. doi: 10.1002/pad.1737

Döring, E., Hartmann, J., Heita-Mwampamba, N., Hützen, W., \& Steinhilper, D. (Eds.). (2007). Water For Life: Lessons learnt from 15 years of German Development Cooperation in the Kilimanjaro Region. Dar es Salaam, Tanzania: German Development Cooperation in Tanzania.

Grove, A. (1993). Water Use by the Chagga on Kilimanjaro. African Affairs, 92(368), 431-448.

Hutchings, P., Chan, M. Y., Cuadrado, L., Ezbakhe, F., Mesa, B., Tamekawa, C., \& Franceys, R. (2015). A systematic review of success factors in the community management of rural water supplies over the past 30 years. Water Policy, 17(5), 963-983.

Iliffe, J. (1979). A Morden History of Tanganyika. Cambridge, USA: Cambridge University Press.

Kelsall, T. (2008). Going with the grain in African development? The APPP Discussion Paper No. 1. London, UK: Africa Power and Politics Programme (APPP), Overseas Development Institute.

Levy, B. (2014b). Working with the Grain: Integrating Governance and Growth in Development Strategies. New York: Oxford University Press.

Ludwig, F. (1999). Church and State in Tanzania: Aspect of a Changing Relationship 1961-1994. Leiden, Boston, Koln: Brill.

Mafikiri, S. A. (2010). Christ as the Mangi: Ideal King of Christian Transformation for a Deeper Evangilisation: A Christology from the Chagga perspective. Nairobi, Kenya: The Catholic University of Eastern Africa.

National Bureau of Statistics. (2013). 2012 Population and Housing Census: Population Distribution by Administrative Areas. Dar es Salaam, Tanzania: United Republic of Tanzania.

Shoup, J. A. (2011). Ethnic groups of Africa and the Middle East: An encyclopedia.

Sun, Y., Asante, F., \& Birner, R. (2010). Opportunities and Challenges of Community-Based Rural Drinking Water Supplies: An Analysis of Water and Sanitation Committees in Ghana IFPRI Discussion Paper 01026: International Food Policy Research Institute (IFPRI). 
UNDP. (2014). Tanzania human development report 2014: Economic transformation for human development. Dar es Salaam, Tanzania: Economic and Social Research Foundation.

UNICEF/WHO. (2015a). Progress on Sanitation and Drinking Water: 2015 Update and MDG Assessment. Geneva: UNICEF and the World Health Organization.

United Republic of Tanzania. (2002b). National Water Policy 2002. Dar es Salaam, Tanzania.

United Republic of Tanzania. (2013a). Tanzania Big Results Now! Road Map National Key Result Area Water 2013/14 - 2015/16. Dar es Salaam: Ministry of Water.

United republic of Tanzania. (2013c). The water sector status report 2013. Dar es Salaam, Tanzania: Ministry of Water.

Water Service Facility. (2014). Wajibu na Majukumu ya Wajumbe wa Bodi ya Wadhamini (Vol. Nov 2014 WSF). Bomang'ombe: Water Service Facility.

Welle, K., \& Williams, J. (2014). Monitoring and addressing governance factors affecting rural water supply sustainability: Regional approach paper based on Global Water Initiative East Africa Governance into Functionality monitoring of water schemes implemented in Ethiopia, Tanzania and Uganda Regional Approach Paper. Kampala, Uganda: Global Water Initiative - East Africa.

Werner, A. (1924). [Kilimanjaro and Its People: A History of the Wachagga, Their Laws, Customs, and Legends, together with Some Account of the Highest Mountain in Africa, Charles Dundas]. Bulletin of the School of Oriental Studies, University of London, 3(3), 563-565. 
Chapter 9

Synthesis 


\section{Introduction}

Public water services are failing urban and rural Tanzanians. The percentage of urban population with piped water dropped from $31 \%$ in 1990 to $28 \%$ in 2015. People in low-income urban areas are forced to rely on informal providers offering water of uncertain quality at unregulated high prices. Sustaining a functional rural water supply infrastructure is also a challenge. Nearly half of rural water points are not functional and about $20 \%$ of newly constructed water points become non-functional within one year. An increasing number of Tanzanians in rural areas are compelled to resort to traditional, unimproved water sources (ponds and streams), thereby endangering their health and wellbeing.

In this final chapter, I conclude my study on the factors affecting citizens' strategies in improving access to water. In section 9.1, I answer the research sub-questions posed in section 1.5. In section 9.2, I answer the main research question. Finally, section 9.3, highlights future directions and consists of two parts: future research and implications for practice.

\subsection{Main contributions}

\section{a) What do official statistics on access to urban water services reveal or conceal?}

Official statistics, such as the Millennium Development Goals (MDGs), represent citizens' access to water services. First, official statistics quantify the proportion of citizens with access to water and enable the setting-up and assessment of goals, targets, policies and tariffs. Second, they allow regional, national and global comparisons regarding access to water and measure progress towards the MDGs. Most importantly, they are supposed to help understand how and why people do not have access to water (Kristof, 2005). Official statistics on access to water measure the proportion of population using an improved water source. Implicit variables for this measurement are the water quantity of 20 litres per person per day, the distance of 400 meters from a water source and the number of people (250) accessing water from an improved water source.

This study has revealed that official statistics on access to urban water services conceal the actual interests of citizens. While official statistics emphasize and quantify the proximity to water sources, e.g. a distance of 400 meters, this metric is irrelevant to citizens who habitually acquire water from street vendors. This study has shown that access to an improved water source does not guarantee adequate quantity, which is of utmost importance to citizens. Further, citizens value water quality depending on the intended use, affordability, convenience and safety. Citizens (i) distinguish various water quality dimensions depending on the intended use, (ii) are less interested in 
distance to a source and attach more value to the current market water price (affordability), (iii) value the timing of access: "a source is reliable when water is available when they need it" (convenience), (iv) prefer bottled water for drinking purposes (safety). Thus, official statistics of access to water are only partially relevant because they conceal those dimensions of access to water that are important for citizens (Obeng-Odoom, 2012; Satterthwaite, 2003, 2016).

This concealing creates a mismatch between the dimensions of access to water that are of interest to citizens and those that the water providers prioritize, following the implicit variables of official statistics, e.g. distance, quantity of water and number of people with access to an improved water source. It is precisely because of this mismatch, that citizens pursue various forms of coping strategies, geared to increase quantity, quality, convenience, and safety. Poor and affluent citizens have different coping strategies. Affluent citizens can afford to invest in coping strategies that guarantee more reliable, relatively higher water quality and long-term access to water, while the poor can only afford short-term coping strategies that solve immediate needs, with relatively lower water quality. Thus, the poor incur a higher monetary and health cost than the affluent.

The new "access to water" definition in the Sustainable Development Goal 6 (SDG 6)-to "ensure availability and sustainable management of water and sanitation for all" by 2030 -is supposed to minimize the mismatch to some extent. SDG 6 extends the MDG focus of "use of an improved source of drinking water" to sustainable management and universal access. The SDG indicator "percentage of population using safely managed drinking water services" refers to the "population using an improved drinking water source which is located on premises, available when needed and free of faecal (and priority chemical) contamination" (WHO-UNICEF, 2015). However, accessing water from improved sources "when needed" remains a challenge even for those with piped drinking water on the premises. Furthermore, the principle of universality is undermined when the capacity of the official water provider and the status of the piped water infrastructure are enough only for a small fraction of the large city population.

\section{b) Which strategies do citizens use to protest substandard water services and to what effect?}

In small cities, customers of water utilities are forced to pay for a failed water infrastructure and an overstaffed bureaucracy. They are not faced with a simple organisational deterioration but with blatant injustice (Rottenburg, 2009). Citizens/clients employ four main protest strategies that vary in intensity and form. The first, "stay and speak up", includes constructive demands to understand how officials work, to articulate needs and to appeal 
for fair treatment. It also includes comparison with better services, threats to demonstrate, resistance to paying water fees, accusations of rip-offs, and locking gates. The second kind, "speak up and leave", includes cursing and citizens' threats to exit the urban water system. The third kind, "resignation", involves speaking up only if visited by water technicians, willingness to follow but not lead demonstrations, reporting problems to friends connected with water technicians, bribes, tampering with water meters and a "things will not change" attitude of passive acceptance. The fourth, "leave and remain silent", includes resorting to water from inferior sources such as water ponds and a significant lowering of expectations.

Responses by the water utility, whether formal or informal, produce predominantly negative outcomes, especially for less privileged customers. There are three reasons for this in Mashujaa town. First, Mashujaa's piped water network is, counter-intuitively, a "differentiated" service: improvements to the water network do not benefit every customer, as one would expect from such a network. The poor do not gain from the "voice" of those who can bribe or pay for repairs unless external assistance can ensure that the poor benefit as well. Second, both citizens and officials know that the water service is in a dismal state-the (dismal) service is not ill-defined. There are no informational asymmetries that would make voice a preferred strategy (Young, 1974), while chronic underperformance lowers customers' expectations and increases the negativity and frustration of the water utility. Third, the design of the customer complaints register, its management and the record keeping at the water utility are utterly inadequate to receive and follow up on citizens' complaints.

Water providers listen to customers conditionally and through informal communication channels. Protest strategies of more privileged citizens or those socially connected to officials are successful. These results match earlier studies showing that monopolistic and rent seeking behaviours characterize small and collapsing water providers (Lovei \& Whittington, 1993). On the positive side, it is encouraging that less privileged customers "stay and speakup". These customers are aware of their entitlements, are willing to exercise voice and "speak truth to power", even if only in personal interactions with officials. Face-to-face protest strategies such as "stay and speak up" suggest that citizens are loyal not to the water provider as an institution but to selected individuals within the organization. Such practices increase opportunities for informality, because they are invisible to the eyes of the urban water utility, consequently making improvements to citizens' access to water more difficult. 


\section{c) How do local actors perceive their own responsibilities and those of other actors and to what extent can a mobile phone-based platform improve rural water services?}

Claims by researchers and development practitioners that citizen apathy and the ignorance of rural water supply actors of their formal responsibilities impede the improvement of rural water supply in general, and in particular the use of ICT in the sector, are contradicted by my findings.

The vibrancy of the Elderly-men for Development Association of Mwembeni (EDAM) contradicts the apathy claim. Tanzanian citizens carefully and continuously negotiate their relationship with the state with the "politics of getting by", especially by keeping the state "at a manageable distance and as such create breathing and operating room for local social structures" (Mulqueen, 2009, p. 5), without too much state interference. In this light, EDAM and the village diaspora appear as informal members of the rural water supply sector in Mashujaa and constitute a useful reaction to the rigidity of the formal rules and procedures.

Local actors (citizens, COWSOs, councillors and district officials) are knowledgeable to a large extent of their own formal responsibilities and communication channels outlined in policies, legislations and regulations. Not only are they aware of the formal responsibilities of other actors, but also of what others are doing informally. Most importantly, it is evident that the distrust among local actors is pervasive. A large part of informal behaviour by COWSOs, councillors and district officials is not useful to citizens, and when it is useful to citizens it is often exclusionary. Informal citizen behaviour is the only one that does not break the law, regulations and procedures and is useful to citizens. Each local actor views the SEMA app differently. Councillors see it as a tool that can keep them informed on water problems, COWSOs see it as a tool that can inform them quickly whether and how the district council will solve the problem, while district officials see it as a tool exclusively for water professionals. In sum, district officials see the app as a streamliner of their formal "responsibilities", while COWSOs and councillors see it as an improvement of their formal "communication channels".

\section{d) How can ICTs play a role in the monitoring by citizens of water services?}

ICTs may have a role in the monitoring of water services, when introduced incrementally ("working with the grain") and in conjunction with non-ICT interventions. This is due to the following factors: First, the monitoring of rural water supply includes a significant amount of discretionary tasks that are difficult and unwise to improve through digitization. Even non-discretionary tasks, which might seem to be easy candidates for digitization, should not be expedited with technology, before new, comprehensive rules and procedures 
are agreed by all concerned, as they might conflict with other discretionary tasks.

Second, tasks unfolding within local institutions of rural water services are infused with an incredible amount of rules and procedures, both formal and informal. While some procedures may appear absurd to an outsider, they reflect a deeply embedded bureaucratic culture that is difficult and even counterproductive to dislodge with technological means.

Third, district water officials find the increasing pressure from the ministry to report rural water-related information upwards in various formats excessive. As Pritchett et al. (2010) argue, any additional "premature load bearing", or pressure on district water officials, based on unrealistic expectations about the improvement of district capacity with digitization, may lead to stress and a weakening or total collapse of capacity. A flexible standards approach to create a modular hierarchy of national, district and village-level water point datasets to release tensions between standardization, required by the Ministry and donors, and localization favoured by the district, and accompanied by intensive capacity building would be worth trying (Braa \& Hedberg, 2002).

Finally, citizen engagement in the ICT-based monitoring of water services may be successful if it enables problem resolution. Tasks outside village and district institutions require the physical presence of skilled individuals at the village in order to build the capacity of COWSOs to repair broken water points without depending on the district council. This is because, the current water policy requires COWSOs to have full responsibility in the management and financing of rural water projects. Information about breakdowns available transparently and in a timely fashion may provide external market parties with the opportunity to stockpile spare parts efficiently and dispatch technicians to the right locations.

Digitizing tasks in information flows should not interfere with the internal functioning of local institutions. Positioning an ICT platform as a possible village-district gateway presumes a willingness to deploy a platform, learn how it can be (ab)used, and redesign it, until a sustainable fit is accomplished. A digital incrementalism of small, reversible changes, sceptical of ICTs that bypass local institutions (Fung et al., 2013), may generate clumsy solutions to rural water services, but an elegant failure becomes less probable.

\subsection{Citizens' strategies}

The 2004 World Development Report distinguished between the traditional "long route" of accountability and an alternative, new "short route," comprising the interactions between providers and their citizens/clients. 
The "short route" in WDR 2004, also labelled "client power", was an important corrective to the pre-occupation of reformers with the traditional long route, which included public sectors reforms, strategies to improve "compacts", and electoral support to amplify "voice". Levy (2014a) pointed out two limitations of the WDR's "short route" approach: the assumption that citizens/clients have leverage over front-line providers and the sole focus on two polar patterns - a hierarchical long-route, and a front-line short route.

This focus obscured the informal spaces in the middle: the layers in-between the top-levels of policymaking and the front-line providers. This thesis bolsters Levy's (2014) critique, as well as the critique of several other similarly-minded scholars (Booth \& Cammack, 2013; Devarajan, 2014; ODI, 2014).

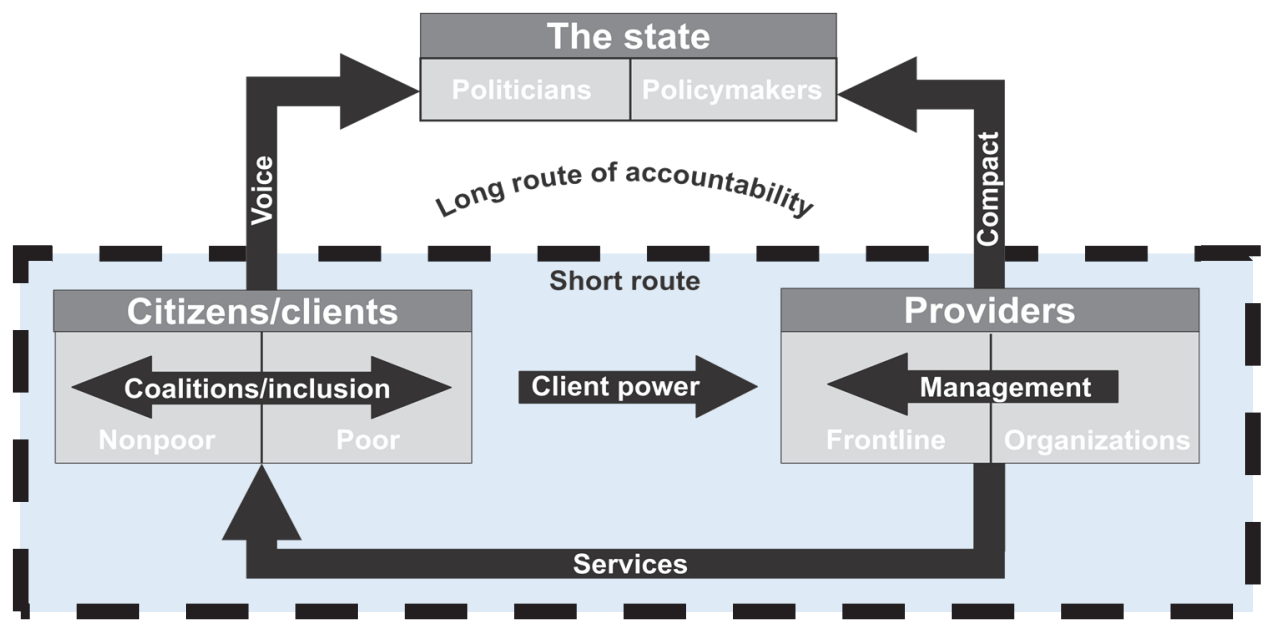

Figure 9.1: Relations of local actors in water services. Adapted from (World Bank, 2003, p. 49)

Below, I use the main categories in the base of the triangle, "short-route", to illustrate that the assumptions implicit in these categories-citizens/clients, providers, and client power-are rather simplistic. My thesis shows that citizens/clients do not have equal leverage over providers and reveals the existence of informal spaces and actors in addition to the main actors depicted in the "short-route" of accountability (Figure 9.1).

\section{Citizens/clients power}

This thesis shows that citizens/clients exercise power-what I called protest strategies in Chapter 5-but individually, and not collectively. Despite the dismal state of water supply in Mashujaa, most customers, poor and betteroff, seem capable of speaking up, which may be considered a form of "client power". Citizens are aware of their entitlements, are willing to exercise voice and "speak truth to power", even if only in personal interactions with officials. 
The costly or inferior alternatives customers have to water, their individualistic relationships, and the sympathy with the officials' predicament inhibit collective action. Protest strategies of citizens who are better-off (and can afford to buy spare parts or bribe) or are connected to officials (as friends, relatives or work colleagues) are successful, while the strategies of citizens who are less privileged are less so. Coalitions between the poor and affluent in Dar es Salaam, and the poor and less privileged in Mashujaa is not possible because the poor do not gain from the "voice" of affluent and the more privileged.

Mobile phone-based ICT platforms do not increase the client power of rural Tanzanians. They are more likely to be used for administrative monitoring of rural water points, which does not necessarily improve rural water services in the absence of a social infrastructure (enterprise) for water point repairs. Only the rural civic associations e.g. EDAM in Mashujaa villages, and the village diaspora have some potential to improve client power. However, their scope is limited and their effects are irregular.

This is different in the Hai and Siha districts. Citizens/clients have a different kind of power that derives from the tribal ethos of the Chagga-a very long history of citizen engagement in collective action (furrows' management), emphasis on education, abhorrence of destitution, a traditional inclination to contribute voluntarily to the production of public goods, and to sanction asocial behaviour, as well as a diaspora regularly engaged in reinforcing their relatives as empowered clients to the water provider, by subsidizing their water fees. Moreover, the religious ethos of the client community in Hai and Siha contributes to willingness to pay fees for water which they consider a sacred good. Therefore, the informality in rural water services in Hai and Siha is deeply embedded socially and eminently productive.

\section{Citizens/clients (coalition/inclusion)}

Another factor affecting citizens' strategies to access water is related to their two-fold exclusion and the absence of coalitions between the poor and the affluent. First, the majority of citizens, particularly the poor and less privileged, are excluded from official statistics used to monitor the service provision, because official statistics on access to urban water services conceal the actual interests of citizens. Second, the majority of citizens, particularly the poor and less privileged, are excluded from public water services. They are excluded from official water provision in two ways: i) they cannot afford high connection fees to the public utility, and/or, ii) they are often located far from the piped water network, making it difficult for them to have a house water connection. Poor citizens in large cities and small towns, especially in unplanned settlements, are even less likely to have a legal water connection. They are forced to exit the public water infrastructure, either by purchasing water from street vendors at exorbitant prices, and/or by opting for free water from 
unimproved sources. Consequently, the poor and less privileged are "punished"; they incur more monetary and health cost for water than the nonpoor. A further consequence of the two-fold exclusion is the absence of coalitions among affluent and poor in the large city and among more or less privileged citizens in small towns. This is because coping strategies exercised by the affluent, who also happen to be better connected socially and can afford bribes, do not benefit the poor.

\section{Providers (frontline and organization)}

Another factor affecting citizens' strategies to access water is related to a mismatch between the dilapidated and vandalised water infrastructure and the ability of the water provider to collect water fees to maintain it. Mashujaa's water infrastructure loses $60 \%$ of produced water and uses three times more staff than the national service benchmark to produce and distribute a certain amount of water, making it at least double as expensive as necessary. Customers are forced to pay for a failing water infrastructure and an overstaffed bureaucracy. They are not faced with a simple organisational deterioration but with blatant injustice (Rottenburg, 2009). Despite the formidable challenges, the frontline providers' commitment to improve services is substantial, as is evident from their efforts to digitize the billing system, to understand better why revenue collection lags behind, to hire a university graduate as secretary of the Customer Care Department. Further, the mismatch between citizens' protest strategies and the complaint mechanisms of the water authority has negative implications, for underprivileged citizens and for the new SDG definition of "access to water".

Yet another factor is the policy regime under which district councils and COWSOs operate. The government's policy rhetoric of decentralisation fuels power struggles between district councils and village COWSOs, the supposed water providers at the village level. COWSOs should bear the full cost of Operation \& Maintenance of rural water schemes. But, in practice communities either refuse or cannot afford to contribute and COWSOs resort to the district for assistance. But, as (Tilley, 2013) argues "district staff are left to sort things out by themselves, with some persisting and others giving up" (p. 8), while communities "limp along" from one water point breakdown to the next (Chowns, 2015 p. 273). Further the procedures for granting resources to COWSOs are infused with an incredible amount of rules and procedures, mostly formal, but also informal. While some procedures may appear absurd to an outsider, they reflect a deeply embedded bureaucratic culture that is difficult and even counterproductive to dislodge with technological means.

Furthermore, a productive interplay between informality and formality contributes significantly to improved water services. In Hai and Siha, the informal retention of rehabilitation funds allows the Water Trusts (the water 
providers) to maintain and rehabilitate the water infrastructure. Rewarding good performance creates competition among Water Trusts and improves service delivery in the long run. An effective electronic billing system, coupled with the informal contributions from the diaspora to relatives' water bills, ensures that rehabilitation funds can be sustained to finance future repairs. Further strategies of the Water Trusts in Hai and Siha districts, conducive to service improvement include limiting the amount of non-revenue water by metering all connections, imposing strict criteria in hiring staff and retaining motivated staff through constant retraining and good salaries. Last but not least, Water Trusts are infused with the religious ethos of paying for water, a "sacred resource".

\section{Relation between Citizens/clients and Providers}

Citizens interact with providers in coping and access strategies both formally and informally. Formally, citizens interact with frontline water providers when applying for new water connections, reporting breakdowns, and paying water bills. Many of these interactions are conducted through face-to-face communication, mostly requiring citizens to visit frontline providers in the office. On the other hand, citizens interact with frontline water providers informally, to acquire illegal water connections. My own experiences in accessing water presented in Section 1.2 demonstrate the prevalence of such informal interactions.

Distrust and lack of transparency between COWSOs (village water providers) and district council officials, and between COWSOs and water users affect negatively the improvement of water services in rural areas. Distrust coupled with extremely long and arduous information flows inhibit efforts to improve rural water services. The detailed description of the tasks in Chapter 7 reveals the often invisible practices of local actors and their daily tribulations with access to water. It portrays them as active and resourceful actors, in contrast to the commonly held belief that they are passive and incompetent. Mobile phone-based ICT platforms may increase transparency only if the water point information is visible to all local stakeholders. The SEMA app could become a new formal communication channel, designed as a transparent dashboard that informs simultaneously citizens, COWSOs, councillors and district officials of the functionality of water points in all villages in the district. This may lead to new informal structures within rural water supply that are more conducive to improvement of rural water services at the district and village levels, but difficult to predict.

The hierarchical organization of Water Trusts in the Hai and Siha districts distributes formal roles and responsibilities clearly between clients and service providers, while at the same time ensuring physical proximity to paying clients and close interactions between clients and providers. The experts in the 
management team, responsible for day-to-day management of water services, relinquish citizens from the "tyranny of participation" implied in the COWSO community-managed water supply (Cooke \& Kothari, 2004).

\subsection{Future direction}

\subsubsection{Future research}

The 2030 Agenda for Sustainable Development, which will steer future research and development, includes a dedicated goal on water and sanitation (SDG 6) that sets out to "ensure availability and sustainable management of water and sanitation for all". SDG 6 extends the MDG focus of "use of an improved source of drinking water" to the sustainable management of and universal access to water. This emphasis suggests the need for an integrated approach to water service delivery. My thesis has shown that sustained access to water is influenced by factors beyond the water sector, including energy, sanitation, education, planning, and financing. Further research is needed to study the integration of water sector activities with activities in the aforementioned sectors to achieve sustainable management of water services.

My thesis employed an exploratory multi-case, qualitative research approach that provides a richer understanding of citizens' strategies to access water services. I identified elements and tasks within the information flows for rural water services and analysed their amenability to digitization as well as the extent to which some of these elements and tasks can be supported by ICT and mobile phone-based platforms for monitoring and repairing rural water points. A similar approach can be used to represent elements and tasks within information flows of other key services, such as sanitation, health, and agriculture.

My thesis has shown that official statistics of access to water are only partially relevant because they conceal those dimensions of access to water that are important for citizens. However, the challenge remains how official statistics can incorporate definitions and measures of access to water that matter to citizens, particularly at the national and utility levels. A study that would tackle this challenge would need to employ a mix of qualitative and quantitative methods.

Inspired by the successful water services in Hai and Siha districts, which reveal a productive interplay of formal and informal organizational structures, further research would be useful in other local contexts to understand how formal and informal structures facilitate and restrict each other. The rationale for a better understanding is not to create a blueprint, but to illuminate trends and patterns 
that can be used to create better institutions not only for water service delivery, but also for other key services.

\subsubsection{Implications for practice}

I recommend a "working with the grain" approach in development interventions which starts with the way things are on the ground and seeks incremental ways of achieving modest gains, without harming the fabric of local institutions. For ICT interventions, this approach implies incrementalism in digitization efforts - the ability to reverse, redesign and redeploy a mobile phone-based platform until it fits sustainably with the local context. "Working with the grain" ensures getting the context right rather than getting the technology right (Fung, Gilman, \& Shkabatur, 2011, slide \#30).

I also recommend an increased professionalization of rural water services, and a decreased dumping of responsibility to community water supply organizations (COWSOs). As the setup of Water Trusts in Hai and Siha shows, communities have delegated the day-to-day management of water infrastructure to professionals with strong managerial and technical skills, while the Water Service Facility (WSF), a sustainable centralized entity for technical operations and maintenance of rural water services, mediates the provision of spare parts. This kind of professional facility is similar to the previous government's commitment to create district "Centres of Excellence" which were supposed to function as central hubs and distribution points for spare parts and services needed by COWSOs (United Republic of Tanzania, 2013a). The recent financing modalities for water point repair in 50 pilot districts in Tanzania (DFIDs Payment-by-Results programme) could support such initiatives by making real-time payments to professionals in these facilities in collaboration with district water engineers. 


\section{References}

Booth, D., \& Cammack, D. (2013). From 'good governance' to governance that works Governance for development in Africa: Solving collective action problems. London: Zed Books.

Braa, J., \& Hedberg, C. (2002). The Struggle for District-Based Health Information Systems in South Africa. The Information Society, 18(2), 113127. doi: $10.1080 / 01972240290075048$

Cooke, B., \& Kothari, U. (Eds.). (2004). Participation: The new tyranny? London: New York: Zed Books.

Devarajan, S. (2014). What the 2004 WDR Got Wrong. http://blogs.worldbank.org/futuredevelopment/what-2004-wdr-gotwrong

Fung, A., Gilman, H. R., \& Shkabatur, J. (2013). Six Models for the Internet plus Politics. International Studies Review, 15(1), 30-47. doi: $10.1111 /$ misr. 12028

Kristof, B. (2005). Monitoring of Water Supply Coverage. WELL fact sheet. Retrieved 25/07, 2013, from http://www.lboro.ac.uk/well/resources/factsheets/fact-sheets-htm/mwsc.htm

Levy, B. (2014a). Function versus form in public sector reform Working with the grain: Integrating governance and growth in development strategies. New York: Oxford University Press.

Lovei, L., \& Whittington, D. (1993). Rent-extracting behavior by multiple agents in the provision of municipal water supply: A study of Jakarta, Indonesia. Water Resources Research, 29(7), 1965-1974. doi: 10.1029/92WR02998

Mulqueen, T. (2009). The Politics of Getting By: Understanding Political Stability in Tanzania. Brookyling College Undergraduate Research Journal, 1 .

Obeng-Odoom, F. (2012). Beyond access to water. Development in Practice, 22(8), 1135-1146. doi: 10.1080/09614524.2012.714744

ODI. (2014). Ten years after the World Development Report 2004: Reflections on the past decade and implications for the future. Paper presented at the WDR Anniversary conference, 28 February - 1 March 2014, Washington DC, USA.

Pritchett, L., Woolcock, M., \& Andrews, M. (2010). Capability Traps? The Mechanisms of Persistent Implementation Failure Working Paper 234. Washington, DC: Center for Global Development.

Rottenburg, R. (2009). Far-fetched facts. A parable of development and humanitarian aid (A. Brown \& T. Lampert, Trans.). Cambridge, Massachusetts \& London, England: The MIT Press.

Satterthwaite, D. (2003). The Millennium Development Goals and urban poverty reduction: great expectations and nonsense statistics. Environment and Urbanization, 15(2), 179-190. doi: $10.1177 / 095624780301500208$ 
Satterthwaite, D. (2016). Missing the Millennium Development Goal targets for water and sanitation in urban areas. Environment and Urbanization, 28(1), 99-118. doi: 10.1177/0956247816628435

Tilley, H. (2013). Unblocking Results: Rural Water in Tanzania. London, UK: Overseas Development Institute.

United Republic of Tanzania. (2013a). Tanzania Big Results Now! Road Map National Key Result Area Water 2013/14 - 2015/16. Dar es Salaam: Ministry of Water.

WHO-UNICEF. (2015). Methodological note: Proposed indicator framework for monitoring SDG targets on drinking water, sanitation, hygiene and wastewater.

World Bank. (2003). World Development Report 2004: Making Services Work for the Poor. Washington, D.C.: World Bank \& Oxford University Press.

Young, D. R. (1974). Exit and voice in the organization of public services. Social Science Information, 13(3), 49-65. doi: 10.1177/053901847401300303 


\section{Bibliography}

Adeniji-Oloukoi, G., Urmilla, B., \& Vadi, M. (2013). Households' coping strategies for climate variability related water shortages in Oke-Ogun region, Nigeria. Environmental Development, 5(0), 23-38. doi: http://dx.doi.org/10.1016/j.envdev.2012.11.005

Allen, A., Dávila, J. D., \& Hofmann, P. (2006). The peri-urban water poor: citizens or consumers? Environment and Urbanization, 18(2), 333-351. doi: $10.1177 / 0956247806069608$

Andrews, M., Pritchett, L., \& Woolcock, M. (2013). Escaping Capability Traps Through Problem Driven Iterative Adaptation (PDIA). World Development, 51, 234-244. doi: http://dx.doi.org/10.1016/j.worlddev.2013.05.011

Aubriot, J. (2014). Conflicts over water in South Africa. Inequalities, social mobilizations and the use of law. Actes De La Recherche En Sciences Sociales, 203, 136-146.

Avila, R., Feigenblatt, H., Heacock, R., \& Heller, N. (2010). Global Mapping of Technology for Transparency and Accountability: New Technologies. London, UK: Transparency \& Accountability Initiative c/o Open Society Foundation.

Ball, M., Rahman, Z., Champanis, M., Rivett, U., \& Khush, R. (2013). Mobile data tools for improving information flow in WASH: Lessons from three field pilots. Bristol, UK: Aquatest Research Programme, University of Bristol.

Barry, B. (1974). Review Article: 'Exit, Voice, and Loyalty'. British Journal of Political Science, 4, 79-107. doi: doi:10.1017/S0007123400009376

Bender, M. V. (2013). Being 'Chagga': Natural Resources, Political Activism, and Identity on Kilimanjaro. The Journal of African History, 54(2), 199220. doi: $10.1017 / \mathrm{s} 0021853713000273$

Berger, P. L., \& Kellner, H. (1981). Sociology Reinterpreted: An Essay on Method and Vocation: Penguin Books.

Bhatnagar, S. (2014). Public service delivery: Role of information and communication technology in improving governance and development impact. Manila: Asian Development Bank.

Booth, D. (2012). Working with the Grain and Swimming against the Tide. Public Management Review, 14(2), 163-180. doi: 10.1080/14719037.2012.657959

Booth, D. (2015). Still watering white elephants? The blueprint versus process debate thirty years on In A. M. Kjær, L. E. Pedersen \& L. Buur (Eds.), Perspectives on politics, production and public administration in Africa, Essays in honor of Ole Therkildsen. Copenhagen: Danish Institute for International Studies.

Booth, D., \& Cammack, D. (2013). From 'good governance' to governance that works Governance for development in Africa: Solving collective action problems. London: Zed Books. 
Bourque, E. C. (2010). Urban Governance and Unequal Geographies of Water in Buguruni Ward, Dar es Salaam, Tanzania (PhD in Geography), Kings College London, London, UK.

Braa, J., \& Hedberg, C. (2002). The Struggle for District-Based Health Information Systems in South Africa. The Information Society, 18(2), 113127. doi: 10.1080/01972240290075048

Braathen, E., Chaligha, A., \& Fjeldstad, O.-H. (2005). Local governance, finances and service delivery in Tanzania: A summary of findings from six councils. Oslo, Norway: Norwegian Institute for Urban and Regional Research (NIBR).

British High Commission Dar es Salaam. (2017). Government of Tanzania launches a nationwide scheme to improve access to water. https://www.gov.uk/government/world-location-news/government-oftanzania-launches-a-nationwide-scheme-to-improve-access-to-water

Bryman, A. (2012). Social Research Methods (Fourth Edition ed.). New York, USA: Oxford University Press.

Budds, J., \& McGranahan, G. (2003). Are the debates on water privatization missing the point? Experiences from Africa, Asia and Latin America. Environment and Urbanization, 15(2), 87-114. doi: $10.1177 / 095624780301500222$

Champanis, M., \& Rivett, U. (2012). Reporting water quality: a case study of a mobile phone application for collecting data in developing countries. Paper presented at the Proceedings of the Fifth International Conference on Information and Communication Technologies and Development, Atlanta, Georgia. http://dl.acm.org/citation.cfm?doid=2160673.2160688

Chaplin, S. E. (1999). Cities, sewers and poverty: India's politics of sanitation. Environment and Urbanization, 11(1), 145-158. doi: $10.1177 / 095624789901100123$

Chaplin, S. E. (2011). Indian cities, sanitation and the state: the politics of the failure to provide. Environment and Urbanization, 23(1), 57-70. doi: $10.1177 / 0956247810396277$

Chen, M. A. (2016). Technology, informal workers and cities: insights from Ahmedabad (India), Durban (South Africa) and Lima (Peru). Environment and Urbanization. doi: 10.1177/0956247816655986

Cheng, D. (2013). (In)visible urban water networks: the politics of nonpayment in Manila's low-income communities. Environment and Urbanization, 25(1), 249-260. doi: 10.1177/0956247812469926

Chowns, E. (2014). The political economy of community management: a study of factors influencing sustainability in malawi's rural water supply sector. (PhD thesis), University of Birmingham, Birmingham, UK.

Chowns, E. (2015). Is Community Management an Efficient and Effective Model of Public Service Delivery? Lessons from the Rural Water Supply Sector in Malawi. Public Administration and Development, 35(4), 263-276. doi: 10.1002/pad.1737 
Cooke, B., \& Kothari, U. (Eds.). (2004). Participation: The new tyranny? London: New York: Zed Books.

Couldry, N. (2010). Why Voice Matters? Culture and Politics After Neoliberalism. London UK: SAGE Publications.

Daily News. (2010, 20 July). End of Dar es Salaam water blues in sight, Daily News.

Devanathan, V. (2013, 5th August). Water mafia cashing in on water scarcity, Collections - Water Crisis, The Times of India. Retrieved from http://articles.timesofindia.indiatimes.com/2013-08-

05/madurai/41091546_1_water-mafia-water-tanker-operatorspackaged-drinking-water

Devarajan, S. (2014). What the 2004 WDR Got Wrong. http://blogs.worldbank.org/futuredevelopment/what-2004-wdr-gotwrong

Development Research Centre. (2010). Blurring the boundaries: Citizen action across states and societies. Brighton: Institute for Development Studies.

DFID. (2015). Phase 2: Rural Water Supply and Sanitation Programme, Tanzania: Annual Review: Department for International Development.

Diani, H. (2009, 24th July). Pay Up: How the Water Mafia Controls Access, JakartaGlobe. Retrieved from http://www.thejakartaglobe.com/archive/pay-up-how-the-water-mafiacontrols-access/

Döring, E., Hartmann, J., Heita-Mwampamba, N., Hützen, W., \& Steinhilper, D. (Eds.). (2007). Water For Life: Lessons learnt from 15 years of German Development Cooperation in the Kilimanjaro Region. Dar es Salaam, Tanzania: German Development Cooperation in Tanzania.

Dowding, K., \& John, P. (2012). Exits, Voices and Social Investment: Citizens' Reaction to Public Services Retrieved from http://itc.eblib.com/patron/FullRecord.aspx?p $=880673$

Dowding, K., John, P., Mergoupis, T., \& Van Vugt, M. (2012). Exit, voice and loyalty: Analytic and empirical developments. European Journal of Political Research, 37(4), 469-495. doi: 10.1023/A:1007134730724

Eichenseher, T. (2008). Water Mafias" Put Stranglehold on Public Water Supply, National Goegraphic news. Retrieved from http://news.nationalgeographic.com/news/2008/08/080821-watermafias.html

ESRC. (2015). ESRC Framework for research ethics Updated January 2015. Swindon, UK: The Economic and Social Research Council (ESRC).

EWURA. (2012). Water Utilities Performance Report 2010/2011: Regional Water Utilities and DAWASCO. Dar es Salaam, Tanzania: Energy and Water Utilities Regulatory Authority (EWURA).

EWURA. (2016). Water Utilities Performance Review Report for the Fiscal Year 2015/2016. Dar es Salaam, Tanzania: Energy and Water Utilities Regulatory Authority (EWURA). 
Fox, J. A. (2015). Social Accountability: What Does the Evidence Really Say? World Development, 72, 346-361. doi: http://dx.doi.org/10.1016/j.worlddev.2015.03.011

Freyhold, M. v. (1979). Ujamaa Villages in Tanzania: Analysis of a Social Experiment. London: Heinemann Educational Books Ltd.

Fung, A., Gilman, H. R., \& Shkabatur, J. (2010a). Impact Case Studies from Middle Income and Developing Countries. Cambridge, MA: Transparency \& Accountability Initiative. c/o Open Society Foundation.

Fung, A., Gilman, H. R., \& Shkabatur, J. (2010b). Technologies of Transparency for Accountability: An Examination of Several Experiences from MiddleIncome and Developing Countries.

Fung, A., Gilman, H. R., \& Shkabatur, J. (2011). Why technology hasn't revolutionized politics. Program on Liberation Technology. CDDRL, Program on Liberation Technology News. Retrieved 5th January, 2013

Fung, A., Gilman, H. R., \& Shkabatur, J. (2013). Six Models for the Internet plus Politics. International Studies Review, 15(1), 30-47. doi: $10.1111 /$ misr. 12028

Furlong, K. (2010). Neoliberal Water Management: Trends, Limitations, Reformulations. Environment and Society: Advances in Research, 1(1), 46-75. doi: 10.3167/ares.2010.010103

Georgiadou, Y., Bana, B., Becht, R., Hoppe, R., Ikingura, J., Kraak, M.-J., Lance, K., Lemmens, R., Lungo, J. H., McCall, M., Miscione, G., \& Verplanke, J. (2011). Sensors, empowerment, and accountability: a Digital Earth view from East Africa. International Journal of Digital Earth, 4(4), 285-304. doi: 10.1080/17538947.2011.585184

Georgiadou, Y., Lungo, J. H., \& Richter, C. (2013). Citizen sensors or extreme publics? Transparency and accountability interventions on the mobile geoweb. International Journal of Digital Earth, 1-18. doi: 10.1080/17538947.2013.782073

Georgiadou, Y., Verplanke, J., Lungo, J., \& Mbise, M. (2016). Water point mapping in Tanzania: Making the voices of data collectors audible. Paper presented at the 7th Rural water supply network (RWSN) forum: Water for everyone, 29 November - 2 December 2016, Abidjan, Côte d'Ivoire.

Giné, R., \& Pérez-Foguet, A. (2008). Sustainability assessment of national rural water supply program in Tanzania. Natural Resources Forum, 32(4), 327342. doi: $10.1111 / j .1477-8947.2008 .00213 . x$

Grove, A. (1993). Water Use by the Chagga on Kilimanjaro. African Affairs, 92(368), 431-448.

Guest, G., Bunce, A., \& Johnson, L. (2006). How Many Interviews Are Enough?: An Experiment with Data Saturation and Variability. Field Methods, 18(1), 59-82. doi: 10.1177/1525822x05279903

Gundry, S. W., Wright, J. A., Conroy, R., Du Preez, M., Genthe, B., Moyo, S., Mutisi, C., Ndamba, J., \& Potgieter, N. (2006). Contamination of drinking water between source and point-of-use in rural households of South Africa 
and Zimbabwe: implications for monitoring the Millennium Development Goal for water. Water Practice and Technology, 1(2).

Gwebu, T. D. (2002). Urban water scarcity management: civic vs. state response in Bulawayo. Habitat International, 26(3), 417-431. doi: http://dx.doi.org/10.1016/S0197-3975(02)00016-4

Hackenbroch, K., \& Hossain, S. (2012). "The organised encroachment of the powerful"-Everyday practices of public space and water supply in Dhaka, Bangladesh. Planning Theory \& Practice, 13(3), 397-420. doi: $10.1080 / 14649357.2012 .694265$

Heald, S. (2002). Domesticating Leviathan: Sungusungu Groups in Tanzania Working Paper No. 6. London, UK: Development Studies Institute (DESTIN), London School of Economics.

Hirschman, A. O. (1970). Exit, Voice and Loyalty: Responses to Decline in Firms, Organizations and States. Cambridge, MA: Harvard University Press.

Hoag, D. H. J. (2013). Developing the Rivers of East and West Africa: An Environmental History. London \& New York: Bloomsburry.

Holzer, B. (2014). The two faces of world society. In B. Holzer \& T. Werron (Eds.), From Globalization to World Society: Neo-Institutional and Systems-Theoretical Perspectives. London/New York: Routledge.

Hooper, M., \& Ortolano, L. (2012). Motivations for slum dweller social movement participation in urban Africa: a study of mobilization in Kurasini, Dar es Salaam. Environment and Urbanization, 24(1), 99-114. doi: $10.1177 / 0956247811435889$

Hutchings, M. T., Dev, A., Palaniappan, M., Srinivasan, V., Ramanathan, N., \& Taylor, J. (2012). Mobile Phone Applications for the Water, Sanitation, and Hygiene (WASH) Sector. Los Angeles, California: Pacific Institute.

Hutchings, P., Chan, M. Y., Cuadrado, L., Ezbakhe, F., Mesa, B., Tamekawa, C., \& Franceys, R. (2015). A systematic review of success factors in the community management of rural water supplies over the past 30 years. Water Policy, 17(5), 963-983.

Hydén, G. (1980). Beyond Ujamaa in Tanzania: underdevelopment and an uncaptured peasantry, London. Berkerly and Los Angels: University of California Press.

Hydén, G. (1999). Top-down democratization in Tanzania. Journal of Democracy, 10(4).

Iacono, J., Brown, A., \& Holtham, C. (2009). Research Methods - A Case Example of Participant Observation. The Electronic Journal of Business Research Methods, 7(1), 39-46.

Iliffe, J. (1979). A Morden History of Tanganyika. Cambridge, USA: Cambridge University Press.

International Energy Agency. (2011). World Energy Outlook 2011. Paris, France: International Energy Agency. 
IRC, \& BRALUP. (1982). Village Water Supply and Community Participation in Tanzania: Report of a National Workshop held in Dar es Salaam, Tanzania, July 14-16, 1981. The Hague, The Netherlands: International Water and Sanitation Centre (IRC) \& Bureau of Resource Assessment and Land Use Planning.

ITU. (2015). ICT Facts \& Figures. The world in 2015. https://www.itu.int/en/ITU-

D/Statistics/Documents/facts/ICTFactsFigures2015.pdf

Janus, H., \& Keijzer, N. (2015). Big Results Now? Emerging Lessons from a Result-Based Aid in Tanzania Discussion Paper 4/2015. Bonn, Germany: Deutsches Institut für Entwicklungspolitik (German Development Institute).

Jimenez, A., \& Perez-Foguet, A. (2010). Building the role of local government authorities towards the achievement of the human right to water in rural Tanzania. Natural Resources Forum, 34(2), 93-105.

Jiménez, A., \& Pérez-Foguet, A. (2010). Challenges for Water Governance in Rural Water Supply: Lessons Learned from Tanzania. International Journal of Water Resources Development, 26(2), 235-248. doi: 10.1080/07900621003775763

Jiménez, A., \& Pérez-Foguet, A. (2011). The relationship between technology and functionality of rural water points: evidence from Tanzania. Water Science and Technology, 63(5), 948-955. doi: 10.2166/wst.2011.274

Jonoski, A., Alfonso, L., Almoradie, A., Popescu, I., van Andel, S. J., \& Vojinovic, Z. (2012). Mobile Phone Applications in The Water Domain. Environmental Engineering and Management Journal, 11(5), 919-930.

Kassenga, G. R. (2007). The health-related microbiological quality of bottled drinking water solid in Dar es Salaam, Tanzania. Journal of Water and Health, 5(1), 179-185. doi: Doi 10.2166/Wh.2006.052

Kayaga, S., Fisher, J., \& Franceys, R. (2009). Improved access to urban water services in Uganda. Proceedings of the Institution of Civil Engineers: Municipal Engineer, 162(3), 165-170.

Keeley, M., \& Graham, J. W. (1991). Exit, voice, and ethics. Journal of Business Ethics, 10(5), 349-355. doi: 10.1007/bf00383236

Kelsall, T. (2008). Going with the grain in African development? The APPP Discussion Paper No. 1. London, UK: Africa Power and Politics Programme (APPP), Overseas Development Institute.

Kelsall, T. (2011). Going with the Grain in African Development? Development Policy Review, 29, s223-s251. doi: 10.1111/j.1467-7679.2011.00527.x

Kelsall, T. (2016). Governance and Service Provision. Professional Development Reading Pack No. 38. University of Birmingham. Birmingham, UK. Retrieved from http://www.gsdrc.org/wpcontent/uploads/2016/04/Governance-and-service-provision_RP.pdf 
Kisanga, D. (2013, 27 February). Hunt for water thieves in Dar starts on high note, News, The Guardian. Retrieved from http://www.ippmedia.com/frontend/index.php?l=51708

Kjellén, M. (2000). Complementary Water Systems in Dar es Salaam, Tanzania: The Case of Water Vending. International Journal of Water Resources Development, 16(1), 143-154. doi: 10.1080/07900620048626

Kjellén, M. (2006). From Public Pipes to Private Hands: Water Access and Distribution in Dar Es Salaam, Tanzania (Illustrated ed.). Stockholm, Sweden: Department of Human Geography, Stockholm University.

Kjellén, M., \& McGranahan, G. (2006). Informal Water Vendors and the Urban Poor Human Settlements Discussion Paper Series London, UK: International Institute for Environment and Development (IIED).

Kochendörfer-Lucius, G., \& Pleskovic, B. (Eds.). (2004). Service Provision for the Poor: Public and Private Sector Cooperation. Washington, DC.: World Bank.

Kombe, W. J. (2000). Regularizing housing land development during the transition to market-led supply in Tanzania. Habitat International, 24(2), 167-184. doi: http://dx.doi.org/10.1016/S0197-3975(99)00036-3

Kombe, W. J. (2005). Land use dynamics in peri-urban areas and their implications on the urban growth and form: the case of Dar es Salaam, Tanzania. Habitat International, 29(1), 113-135. doi: http://dx.doi.org/10.1016/S0197-3975(03)00076-6

Kristof, B. (2005). Monitoring of Water Supply Coverage. WELL fact sheet. Retrieved 25/07, 2013, from http://www.lboro.ac.uk/well/resources/factsheets/fact-sheets-htm/mwsc.htm

Kudat, A., Bell, M. E., Boland, J. J., Humplick, F., Madanat, S., \& Mukherjee, N. I. (1993). Reliability of Water Supply in Developing Countries: The Emperor Has No Clothes. Washington, DC: The World Bank.

Kühl, S. (2013). Organizations: A Systems Approach (P. Schmitz, Trans.): Routledge.

Kyessi, A. G. (2005). Community-based urban water management in fringe neighbourhoods: the case of Dar es Salaam, Tanzania. Habitat International, 29(1), 1-25. doi: 10.1016/s0197-3975(03)00059-6

Levy, B. (2014a). Function versus form in public sector reform Working with the grain: Integrating governance and growth in development strategies. New York: Oxford University Press.

Levy, B. (2014b). Working with the Grain: Integrating Governance and Growth in Development Strategies. New York: Oxford University Press.

Lovei, L., \& Whittington, D. (1993). Rent-extracting behavior by multiple agents in the provision of municipal water supply: A study of Jakarta, Indonesia. Water Resources Research, 29(7), 1965-1974. doi: 10.1029/92WR02998

Ludwig, F. (1999). Church and State in Tanzania: Aspect of a Changing Relationship 1961-1994. Leiden, Boston, Koln: Brill. 
Madulu, N. F. (2000). Changing Water Needs and Uses in Rural Communities of Mwanza Region, Tanzania. Paper presented at the 1st WARFSA/WaterNet Symposium: Sustainable Use of Water Resources; 1 2 November 2000, Maputo, Mozambique. http://www.waternetonline.ihe.nl/downloads/uploads/symposium/moza mbique-2000/MADULU.PDF

Mafikiri, S. A. (2010). Christ as the Mangi: Ideal King of Christian Transformation for a Deeper Evangilisation: A Christology from the Chagga perspective. Nairobi, Kenya: The Catholic University of Eastern Africa.

Marson, M., \& Savin, I. (2015). Ensuring Sustainable Access to Drinking Water in Sub Saharan Africa: Conflict Between Financial and Social Objectives. World Development, 76, 26-39. doi: http://dx.doi.org/10.1016/j.worlddev.2015.06.002

Masanyiwa, Z. S., Niehof, A., \& Termeer, C. J. A. M. (2014). Users' perspectives on decentralized rural water services in Tanzania. Gender, Place \& Culture, 22(7), 920-936. doi: 10.1080/0966369X.2014.917283

Mashauri, D. A., \& Katko, T. S. (1993). Water-Supply Development and Tariffs in Tanzania - From Free-Water Policy towards Cost Recovery. Environmental Management, 17(1), 31-39. doi: 10.1007/bf02393792

Mayo, A. W., \& Nkiwane, L. (2013). The role of community participation on cost recovery and sustainability of rural water supply projects in Hai District, Tanzania. Journal of Environmental Science and Water Resources, 2(11), 388 - 395.

McGee, R., \& Gaventa, J. (2010). Review of Impact and Effectiveness of Transparency and Accountability Initiatives: Synthesis Report. London, UK: Institute of Development Studies.

Metwally, A. M., Ibrahim, N. A., Saad, A., \& Abu El-Ela, M. H. (2006). Improving the roles of rural women in health and environmental issues. International Journal of Environmental Health Research, 16(2), 133-144. doi: $10.1080 / 09603120500539208$

Mulqueen, T. (2009). The Politics of Getting By: Understanding Political Stability in Tanzania. Brookyling College Undergraduate Research Journal, 1.

Mwanza, D. D. (2001). Reforming Africa's water and sanitation sector: Issues and challenges. Loughborough: Water Engineering \& Development Centre.

Myers, M. (2010). Why Radio Matters: Making the case for radio as a medium for development. Washington DC: Developing Radio Partners.

National Bureau of Statistics. (2013). 2012 Population and Housing Census: Population Distribution by Administrative Areas. Dar es Salaam, Tanzania: United Republic of Tanzania.

Nganyanyuka, K., Martinez, J., Wesselink, A., Lungo, J. H., \& Georgiadou, Y. (2014). Accessing water services in Dar es Salaam: Are we counting what 
counts? Habitat International, 44, 358-366. doi: http://dx.doi.org/10.1016/j.habitatint.2014.07.003

Ntouda, J., Sikodf, F., Ibrahim, M., \& Abba, I. (2013). Access to drinking water and health of populations in Sub-Saharan Africa. Comptes Rendus Biologies, 336(5-6), 305-309. doi: http://dx.doi.org/10.1016/j.crvi.2013.06.001

Nyarko, K. B., Odai, S. N., Owusu, P. A., \& Quartey, E. K. (2008). Water Supply Coping Strategies in Accra. Paper presented at the 33rd WEDC International Conference: Access to Sanitation and Safe Water: Global Partnerships and Local Actions, Accra, Ghana. http://wedc.Iboro.ac.uk/resources/conference/33/Nyarko_K2_GHA.pdf

Nyerere, J. K. (1968). UJAMAA: Essays on Socialism. Dar es Salaam: Oxford University Press.

Nyoka, K. w. (2013, 24th August). Tanzania: Institutionalising Corruption Any Hope of Taming It?, Opinion, Daily News. Retrieved from http://www.dailynews.co.tz/index.php/columnists/columnists/21413institutionalising-corruption-any-hope-of-taming-it

O'Hara, S., Hannan, T., \& Genina, M. (2008). Assessing access to safe water and monitoring progress on MDG7 target 10 (access to safe water and basic sanitation): Lessons from Kazakhstan. Water Policy, 10(1), 1.

Obeng-Odoom, F. (2012). Beyond access to water. Development in Practice, 22(8), 1135-1146. doi: 10.1080/09614524.2012.714744

ODI. (2014). Ten years after the World Development Report 2004: Reflections on the past decade and implications for the future. Paper presented at the WDR Anniversary conference, 28 February - 1 March 2014, Washington DC, USA.

Pastore, M. C. (2015). Reworking the relation between sanitation and the city in Dar es Salaam, Tanzania. Environment and Urbanization, 27(2), 473488. doi: $10.1177 / 0956247815592285$

Pattanayak, S. K., Yang, J.-C., Whittington, D., \& Kumar, K. C. B. (2005). Coping with unreliable public water supplies: Averting expenditures by households in Kathmandu, Nepal. Water Resources Research, 41(W02012).

Paul, S. (1991). Accountability in public services: Exit, Voice and Capture WPS 614. Washington, DC: The World Bank.

Paul, S. (1992). Accountability in public services: Exit, voice and control. World Development, 20(7), 1047-1060. doi: http://dx.doi.org/10.1016/0305750X(92)90130-N

Peal, A. (2014). Reducing vandalism of water and sanitation infrastructure: Experience from Zambia's Copperbelt. Periodic Brief. https://assets.publishing.service.gov.uk/media/57a089e6ed915d622c00 0453/TB013_ReducingVandalism.pdf 
Pearce, J., Welle, K., \& Dickinson, N. (2013). Information and Communication Technologies (ICTs) for monitoring sustainable service delivery. The Hague, The Netherlands: IRC.

Penrose, K., Castro, M. C. d., Werema, J., \& Ryan, E. T. (2010). Informal Urban Settlements and Cholera Risk in Dar es Salaam, Tanzania. PLoS Negl Trop Dis, 4(3), e631. doi: 10.1371/journal.pntd.0000631

Pigeon, M. (2012). From Fiasco to DAWASCO: Remunicipalising Water Systems in Dar es Salaam, Tanzania. In M. Pigeon, D. A. McDonald, O. Hoedeman \& S. Kishimoto (Eds.), Remunicipalisation: Putting Water Back into Public Hands. Amsterdam, The Netherlands: Transnational Institute.

Pritchett, L. (2013). The World Bank and public sector management: what next? International Review of Administrative Sciences, 79(3), 413-419.

Pritchett, L., \& Woolcock, M. (2004). Solutions When the Solution is the Problem: Arraying the Disarray in Development. World Development, 32(2), 191-212. doi: 10.1016/j.worlddev.2003.08.009

Pritchett, L., Woolcock, M., \& Andrews, M. (2010). Capability Traps? The Mechanisms of Persistent Implementation Failure Working Paper 234. Washington, DC: Center for Global Development.

Rasmus Heltberg, N. H., Anna Reva. (2012). Living through Crises: How the Food, Fuel, and Financial Shocks Affect the Poor. In N. H. Rasmus Heltberg, Anna Reva (Series Ed.) Retrieved from http://issuu.com/world.bank.publications/docs/9780821389409

Rottenburg, R. (2009). Far-fetched facts. A parable of development and humanitarian aid (A. Brown \& T. Lampert, Trans.). Cambridge, Massachusetts \& London, England: The MIT Press.

Satterthwaite, D. (2003). The Millennium Development Goals and urban poverty reduction: great expectations and nonsense statistics. Environment and Urbanization, 15(2), 179-190. doi: $10.1177 / 095624780301500208$

Satterthwaite, D. (2016). Missing the Millennium Development Goal targets for water and sanitation in urban areas. Environment and Urbanization, 28(1), 99-118. doi: 10.1177/0956247816628435

Satterthwaite, D., \& Mitlin, D. (2013). A future that low-income urban dwellers want, and can help secure. London, UK: International Institute for Environment and Development (IIED).

Schedler, A. (2002). My Vote? Not for Sale: How Mexican Citizens View Electoral Clientelism. Paper presented at the The Comparative Politics of Vote Buying, Cambridge, Massachusetts.

Scott, J. C. (1985). Weapons of the Weak: Everyday Forms of Peasant Resistance. New Haven: Yale University Press.

Scott, J. C. (2008). Professor James Scott's Lecture Transcript. Glasgow: Glasgow Centre for Population Health, University of Glasgow.

Shoup, J. A. (2011). Ethnic groups of Africa and the Middle East: An encyclopedia. 
Smiley, S. L. (2009). The city of three colors: Segregation in colonial dar es salaam 1891-1961. Historical Geography, 37, 178-196.

Smiley, S. L. (2016). Water Availability and Reliability in Dar es Salaam, Tanzania. The Journal of Development Studies, 1-15. doi: 10.1080/00220388.2016.1146699

SNV. (2010). Public Accountability in Tanzania Initiative: Brief 1: Approach, Results \& Operational Lessons http://www.snv.org/public/cms/sites/default/files/explore/download/brie f_1_public_accountability_in_tanzania_pata_initiative.pdf

Spicker, P. (2007). Research without consent. Social Research Update, Winter 2007(51).

Srivastava, V., \& Larizza, M. (2013). Working with the grain for reforming the public service: A live example from Sierra Leone. International Review of Administrative Sciences, 79(3), 458-485. doi: $10.1177 / 0020852313491513$

Stoler, J. (2012). Improved but unsustainable: accounting for sachet water in post-2015 goals for global safe water

Communication brève: Améliorée mais non durable: Place de l'eau en sachet dans les objectifs mondiaux pour l'eau sure après 2015

Comunicación corta: Mejora si, pero insostenible: Teniendo en cuenta el agua envasada en bolsas dentro de los objetivos posteriors al 2015 de un agua segura a nivel global. Tropical Medicine \& International Health, 17(12), 1506-1508. doi: 10.1111/j.1365-3156.2012.03099.x

Suchman, L. (1995). Making work visible. Commun. ACM, 38(9), 56-64. doi: $10.1145 / 223248.223263$

Sun, Y., Asante, F., \& Birner, R. (2010). Opportunities and Challenges of Community-Based Rural Drinking Water Supplies: An Analysis of Water and Sanitation Committees in Ghana IFPRI Discussion Paper 01026: International Food Policy Research Institute (IFPRI).

Taylor, B. (2011a). Maji Matone hasn't Delivered. Time to embrace failure, learn and move on Daraja Blog (Vol. 14/07/2012). Njombe: Daraja Development Ltd.

Taylor, B. (2011b). Maji Matone hasn't Delivered. Time to embrace failure, learn and move on. Retrieved from http://blog.daraja.org/2011/12/majimatone-hasnt-delivered-time-to.html

Taylor, B. (2012a). Why did Maji Matone fail? 1. Low-tech obstacles to hightech solutions? Retrieved from http://blog.daraja.org/2012/02/why-didmaji-matone-fail-1-low-tech.html

Taylor, B. (2012b). Why Did Maji Matone Fail? 2. The World of Water Supply? Retrieved from http://blog.daraja.org/2012/02/why-did-maji-matonefail-2-world-of.html

Taylor, B. (2012c). Why Did Maji Matone Fail? 3. Citizens' Engagement, Risk and Apathy? Retrieved from http://blog.daraja.org/2012/02/why-didmaji-matone-fail-3-citizens.html 
Taylor, B. (2012d). Why Did Maji Matone Fail? 3. Citizens' Engagement, Risk and Apathy? Daraja Blog (Vol. 2012). Njombe: Daraja Development Ltd.

The Guardian. (2005, 25 November). Kikwete promises to end Dar water woes, The Guardian.

Therkildsen, O. (1988). Watering White Elephants: Lessons from DonorFunded Planning and Implementation of Rural Water Supplies in Tanzania. Uppsala: Scandinavian Institute of African Studies.

Tilley, H. (2013). Unblocking Results: Rural Water in Tanzania. London, UK: Overseas Development Institute.

Toyama, K. (2016). Global computing: Internet and inequality. Communications of the ACM April 2016, 59(4), 28-30.

Twaweza. (2008). Fostering an Ecosystem of change in East Africa through Imagination, Citizen Agency and Public Accountability Twaweza Strategy. Dar es Salaam, Tanzania: Twaweza.

Twaweza. (2013). Sauti za Wananchi: Collecting national data using mobile phones. Dar es Salaam, Tanzania: Twaweza.

UNDP. (2014). Tanzania human development report 2014: Economic transformation for human development. Dar es Salaam, Tanzania: Economic and Social Research Foundation.

UNICEF/WHO. (2012). Progress on drinking water and sanitation: 2012 Update. New York: WHO/UNICEF Joint Monitoring Programme for Water Supply and Sanitation.

UNICEF/WHO. (2015a). Progress on Sanitation and Drinking Water: 2015 Update and MDG Assessment. Geneva: UNICEF and the World Health Organization.

UNICEF/WHO. (2015b). Progress on Sanitation and Drinking Water: 2015 Update and MDG Assessment. United States of America: UNICEF and The World Health Organization.

United Nations. (1977). Report of the United Nations Water Conference, Mar del Plata, March 14- 25, 1977. New York: United Nations.

United Nations. (2015). ICTs for a Sustainable World. Retrieved 19 September, 2016, from http://www.un.org/sustainabledevelopment/blog/2015/10/icts-for-asustainable-world/

United Nations. (2016). Goal 6: Ensure access to water and sanitation for all. Retrieved 19 September, 2016, from http://www.un.org/sustainabledevelopment/water-and-sanitation/

United Republic of Tanzania. (1982). The Local Government (District Authorities) Act, 1982. Dar es Salaam, Tanzania: United Republic of Tanzania.

United Republic of Tanzania. (1998a). Local Government Reform Programme Policy Paper on Local Government Reform. Dar es Salaam, Tanzania: Ministry of Regional Administration and Local Government. 
United Republic of Tanzania. (1998b). Water Works Ordinance: Chaper 281 of the Laws (Revised) Legislation and Operation Guidelines for Urban Water and Sewerage Authority. Dar es Salaam, Tanzania: Ministry of Water.

United Republic of Tanzania. (2002a). National Water Policy. Dar es Salaam: United Republic of Tanzania.

United Republic of Tanzania. (2002b). National Water Policy 2002. Dar es Salaam, Tanzania.

United Republic of Tanzania. (2006). Water Sector Development Programme (2005-2025) Consolidated Report. Dar es Salaam, Tanzania: Ministry of Water.

United Republic of Tanzania. (2009). Tanzania Water Supply and Sanitation Act (2009). Dar es Salaam, Tanzania: United Republic of Tanzania.

United Republic of Tanzania. (2010). Mwongozo Kuhusu Uundaji na Usajili wa Vyombo aya Watumiaji Maji Vijijini (Guidelines for Establishment and Registration of Community Owned Water Supply Organisations). Dar es Salaam, Tanzania: Ministry of Water.

United Republic of Tanzania. (2013a). Tanzania Big Results Now! Road Map National Key Result Area Water 2013/14 - 2015/16. Dar es Salaam: Ministry of Water.

United Republic of Tanzania. (2013b). Water sector budget for the financial year 2013/2014. Dar es Salaam, Tanzania: Ministry of Water.

United republic of Tanzania. (2013c). The water sector status report 2013. Dar es Salaam, Tanzania: Ministry of Water.

United Republic of Tanzania. (2014). The Water Sector Status Report 2014: Marking the End of WSDP Phase-I. Dar es Salaam, Tanzania: Ministry of Water.

United Republic of Tanzania. (2015a). Processes \& Procedures for Updating Rural Water Point Data in Tanzania: User Manual. Dar es Salaam, Tanzania: Ministry of Water, Rural Water Supply Division (RWSD).

United Republic of Tanzania. (2015b). Tanzania Development Vision 2015: Big Results Now: 2013/2014 Annual Report. Dar es Salaam, Tanzania: President's Delivery Bureau.

van Dijk, T. (2011). Networks of Urbanization in Two Indian Cities. Environment and Urbanization Asia, 2(2), 303-319. doi: 10.1177/097542531100200211

Venugopal, V., \& Yilmaz, S. (2010). Decentralization in Tanzania: An assessment of local government discretion and accountability. Public Administration and Development, 30(3), 215-231. doi: 10.1002/pad.556

Virjee, K., \& Gaskin, S. (2010). Coping with poor water services and the demand for change in Trinidad and Tobago. Water International, 35(3), 285-297. doi: 10.1080/02508060.2010.487299

Visser, W., \& Twinomurinzi, H. (2008). E-Government \& Public Service Delivery: Enabling ICT to put "People First" - A Case Study from South Africa. 
Wacquant, L. (2005). Habitus. In J. Becket \& Z. Milan (Eds.), International Encyclopedia of Economic Sociology (pp. 315-321). London: Routledge.

Water Service Facility. (2014). Wajibu na Majukumu ya Wajumbe wa Bodi ya Wadhamini (Vol. Nov 2014 WSF). Bomang'ombe: Water Service Facility.

Welle, K., \& Williams, J. (2014). Monitoring and addressing governance factors affecting rural water supply sustainability: Regional approach paper based on Global Water Initiative East Africa Governance into Functionality monitoring of water schemes implemented in Ethiopia, Tanzania and Uganda Regional Approach Paper. Kampala, Uganda: Global Water Initiative - East Africa.

Welle, K., Williams, J., \& Pearce, J. (2016). ICTs Help Citizens Voice Concerns over Water - Or Do They? IDS Bulletin, 47(1), 41-51. doi: http://dx.doi.org/10.19088/1968-2016.105

Werner, A. (1924). [Kilimanjaro and Its People: A History of the Wachagga, Their Laws, Customs, and Legends, together with Some Account of the Highest Mountain in Africa, Charles Dundas]. Bulletin of the School of Oriental Studies, University of London, 3(3), 563-565.

Whittington, D., Lauria, D. T., \& Mu, X. (1991). A study of water vending and willingness to pay for water in Onitsha, Nigeria. World Development, 19(2), 179-198. doi: http://dx.doi.org/10.1016/0305-750X(91)90254-F

WHO-UNICEF. (2015). Methodological note: Proposed indicator framework for monitoring SDG targets on drinking water, sanitation, hygiene and wastewater.

Williams, J., Welle, K., \& Pearce, J. (2016). How can ICT initiatives be designed to improve rural water supply? Brighton: IDS and WaterAid.

World Bank. (2003). World Development Report 2004: Making Services Work for the Poor. Washington, D.C.: World Bank \& Oxford University Press.

World Bank. (2014). World development report 2015: Mind and Society, Behavior. Retrieved 19 October, 2014, from http://go.worldbank.org/HYR6FHEK60

World Bank. (2015). Mobile cellular subscriptions (per 100 people). Retrieved 13 March 2016, from http://data.worldbank.org/indicator/IT.CEL.SETS.P2

World Bank. (2016). World Development Report 2016: Digital Dividends. NewYork, USA: The World Bank.

Yin, R. K. (1981). The case study crisis: some answers. Administrative Science Quarterly, 26, 58-65.

Yin, R. K. (2009). Case study research: Design and methods (4th ed.). Thousand Oaks, CA: Sage.

Yin, R. K. (2011). Qualitative Research From Start to Finish. New York, U.S.A: The Guilford Press.

Young, D. R. (1974). Exit and voice in the organization of public services. Social Science Information, 13(3), 49-65. doi: 10.1177/053901847401300303 
Yusra, S. (2011). Assessing the motivation to submit VGI: Case study of a human sensor web in Zanzibar. (MSc thesis), University of Twente, Enschede, Netherlands.

Zawahri, N., Sowers, J., \& Weinthal, E. (2011). The Politics of Assessment: Water and Sanitation MDGs in the Middle East. Development and Change, 42(5), 1153-1178. doi: 10.1111/j.1467-7660.2011.01730.x

Zérah, M.-H. (2000). Household strategies for coping with unreliable water supplies: the case of Delhi. Habitat International, 24(3), 295-307. doi: http://dx.doi.org/10.1016/S0197-3975(99)00045-4

Zinnbauer, D., \& Dobson, R. (Eds.). (2008). Global Corruption Report 2008: Corruption in the Water Sector. New York, USA: Cambridge University Press. 


\section{Summary}

Public water services are failing urban and rural Tanzanians. The percentage of urban population with piped water dropped from $31 \%$ in 1990 to $28 \%$ in 2015. People in low-income urban areas are forced to rely on informal providers offering water of uncertain quality at unregulated high prices. Sustaining a functional rural water supply infrastructure is also a challenge. Nearly half of rural water points are not functional and about $20 \%$ of newly constructed water points become non-functional within one year. An increasing number of Tanzanians in rural areas are compelled to resort to traditional, unimproved water sources (ponds and streams), thereby endangering their health and wellbeing.

Recent developments in information and communication technologies (ICT), particularly the penetration of mobile phones in Sub-Saharan Africa, have raised hopes among development practitioners and researchers on the potential for leveraging technology to improve access to public services in general and to safe and clean drinking water in particular. ICT and mobile phone-based platforms offer opportunities for a quick and more affordable mechanism for two-way communication between citizens and service providers or governments. Several such platforms have been studied and compared for a variety of key services in various countries in the global South. However, these studies either explain the failure or success of a platform in hindsight, or hide patterns of local variation in homogenized national averages of crossnational comparisons. The process, the "how to" develop and deploy them, is missing. This thesis asks "which factors affect citizens' opportunities to improve access to water services and how?" The research findings are:

First, official statistics such as the Millennium Development Goals do not count/reveal the access to drinking water that counts for urban citizens, especially the poor, in large cities like Dar es Salaam. There is a bias towards formal state or privatised citywide systems, concealing the mostly informal, small-scale citizens' strategies to access water.

Second, citizens in small towns deploy four strategies to protest the severe deterioration inn performance of the water authority: "stay and speak up", "speak up and leave", "resignation" and "leave and remain silent." The substantial mismatch between customers' protest strategies and the formal/informal complaint mechanisms of the water authority has negative implications especially for less privileged small-town citizens.

Third, actors in rural water supply are aware of their own formal responsibilities and those of others, as well as of the formal channels through which to communicate, despite claims for the opposite. There is strong 
evidence of informality that either improves or does not improve rural water services for citizens. The only informality that is useful to citizens is practiced by citizens themselves.

Fourth, ICT platforms for monitoring and repairing rural water points should start by digitally transforming tasks with high transaction-intensiveness and low discretion that occur outside village and district institutions. Actors in rural water supply should collaboratively simplify formal rules and procedures that govern information flows within local institutions, before considering further task digitization.

Fifth, a productive interplay between formal and informal practices can improve citizens' access to water and make the achievement of "universal" and "when needed" access to water (Sustainable Development Goal (SDG) 6) more likely. 


\section{Samenvatting}

Publieke watervoorziening in Tanzania stelt inwoners van de stad en op het platteland teleur. Het percentage stedelijke bevolking met een leidingwateraansluiting is gedaald van $31 \%$ in 1990 tot $28 \%$ in 2015. Mensen in stedelijke gebieden met een laag inkomen zijn hierdoor afhankelijk van informele waterverkopers die water van onzekere kwaliteit bieden tegen ongereguleerde hoge prijzen. Het onderhouden van een functionele plattelandswaterinfrastructuur is ook een uitdaging. Bijna de helft van de waterpunten op het platteland zijn niet functioneel en ongeveer $20 \%$ van nieuw geïnstalleerde waterpunten zijn binnen een jaar niet meer functioneel. Een toenemend aantal Tanzanianen op het platteland is daarom gedwongen om gebruik te maken van traditionele, onveilige waterbronnen (vijvers en beekjes), waardoor hun gezondheid en welzijn worden bedreigd.

De recente ontwikkelingen in informatie- en communicatietechnologie (ICT), met name de brede beschikbaarheid van mobiele telefonie in Midden en Zuidelijk Afrika, hebben verwachtingen gewekt bij ontwikkelingswerkers en onderzoekers over het potentieel om deze technologie te gebruiken om specifiek de toegang tot veilig en schoon drinkwater te verbeteren, en de publieke dienstverlening in het algemeen. ICT- en mobiele telefonieplatforms bieden kansen voor een snel en betaalbaar communicatiemechanisme tussen burgers en dienstverleners of overheden. Verschillende platforms zijn onderzocht en vergeleken op basis van een aantal cruciale publieke diensten in verschillende landen in het 'globale zuiden'. Deze studies verklaren echter slechts het falen of het succes van een platform en geven geen lokale variabiliteitspatronen weer omdat internationale vergelijkingen alleen gemaakt kunnen worden op basis van geaggregeerde nationale gemiddelden. Tevens ontbreekt meestal de procesbeschrijving 'hoe' iets ontwikkeld en geïmplementeerd wordt. In dit proefschrift wordt de vraag gesteld: "welke factoren beïnvloeden op welke manier de mogelijkheden die burgers hebben om de toegang tot en kwaliteit van publieke watervoorziening te verbeteren?" De onderzoeksresultaten zijn als volgt:

Ten eerste, in grote steden zoals Dar es Salaam, tellen/onthullen de officiële statistieken, zoals de millenniumdoelstellingen (MDG's), niet de toegang tot drinkwatervoorzieningen op een manier die van toepassing is op de arme stedelijke bevolking. $\mathrm{Er}$ is een over-representatie van formele, publieke of geprivatiseerde, stads brede watervoorzieningen, waardoor veel voorkomende informele, kleinschalige burgerinitiatieven in de watervoorziening verborgen blijven.

Ten tweede, burgers in kleine steden gebruiken vier strategieën om te protesteren tegen de ernstige verslechtering van dienstverlening door de 
waterautoriteit: "klant blijven, maar zich uitspreken", "uitspreken en vertrekken", "ontslag nemen" en "in stilte vertrekken". De substantiële mismatch tussen de (in-) formele klachtenmechanismen van de waterautoriteit en deze proteststrategieën van klanten, heeft vooral negatieve gevolgen voor minder bevoorrechte burgers.

Ten derde zijn actoren in de rurale watervoorziening zich, ondanks meldingen van het tegendeel, bewust van hun eigen formele verantwoordelijkheden en die van anderen, evenals van de formele kanalen waarmee zij kunnen communiceren. Er is sterk bewijs dat de informele sector zowel zorgt voor verbetering als wel verslechtering van de publieke rurale watervoorziening aan burgers. De enige informaliteit die echter nuttig is voor burgers, is die door henzelf wordt uitgevoerd.

Ten vierde moeten ICT-platforms voor het monitoren en repareren van plattelandswaterpunten beginnen met het informatiseren van taken met hoge transactie-intensiviteit en lage discretie, die plaatsvinden buiten de institutionele kaders van lokale overheden. Actoren in de rurale watervoorziening zouden voordat verdere taakdigitalisering overwogen wordt, samen moeten werken in het vereenvoudigen van formele regels en procedures die de informatiestromen binnen de lokale instellingen beheersen.

Ten vijfde kan een productief samenspel tussen de formele en informele sector de toegang van burgers tot veilig drinkwater verbeteren en het bereiken van "universele" toegang tot veilig drinkwater "op aanvraag" (Duurzame Ontwikkelingsdoelstelling (SDG) 6) beter haalbaar maken. 


\section{ITC Dissertation List}

https://www.itc.nl/Pub/research programme/Research-review-andoutput/PhD-Graduates 